\title{
CONTEMPORARY ECONOMICS
}

Quarterly of University of Finance and Management in Warsaw

Volume 5 Issue 3

September 2011

SPECIAL ISSUE

\section{SOCIAL DIAGNOSIS 2011}

OBJECTIVE AND SUBJECTIVE QUALITY OF LIFE IN POLAND

\section{DIAGNOZA SPOŁECZNA 2011 WARUNKI I JAKOŚĆ ŻYCIA POLAKÓW}

Edited by: Janusz Czapiński and Tomasz Panek

Raport Diagnoza Społeczna 2011 finansowany przez:

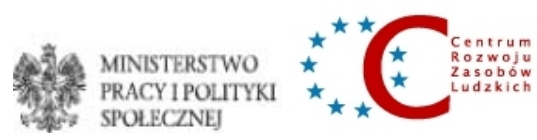

UNIA EUROPEJSKA
EUROPEJSKI FUNDUSZ SPOLECZNNY
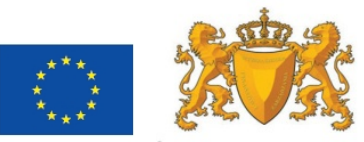


\section{CONTEMPORARY ECONOMICS}

ABSTRACTED/INDEXED:

- Cabell's Directories

- ECONIS

- EconStor

- GALE Science in Context

- Ministry of Science and Higher Education list of scored journals (rating score 9 pts)

- Research Papers in Economics (RePEc)

- SCOPUS

- The Central European Journal of Social Sciences and Humanities

- The International Bibliography of the Social Sciences (IBSS)/ProQuest

- Ulrichsweb

Contemporary Economics is published with the financial support of Polish Ministry of Science and Higher Education, in the frame of research supporting activity and programme INDEX PLUS.

\section{Academic Board}

Icek Ajzen (USA)

Damodaran Appukuttan Nair (India)

Zenon Biniek (Poland)

Constantin A. Bob (Romania)

Wiesław Dębski (Poland)

Bruno S. Frey (Switzerland)

Masahiko Gemma (Japan)

Kjell Åge Gotvassli (Norway)

Adriana Grigorescu (Romania)

Zoran Ivanovic (Croatia)

Sten Jönsson (Sweden)

Victor Martinez Reyes (USA)

Ieva Meidute (Lithuania)

Fatmir Memaj (Albania)

Grażyna Rytelewska (Poland)

Shelby D. Hunt (USA)

Maria Sierpińska (Poland)

President of Academic Board

Miemie Struwig (South Africa)

Tadeusz Szumlicz (Poland)

\section{Editorial Board}

Witold Jakóbik

Henryk Król

Editor in Chief

Witold Małecki

Danuta Mliczewska

Deputy Editor in Chief

Włodzimierz Rembisz

Marcin Staniewski

Deputy Editorial Manager

Piotr Szczepankowski

Editorial Manager

Ryszard Wilczyński

\section{Address of Editors:}

\section{CONTEMPORARY ECONOMICS}

University of Finance and Management in Warsaw

01 - 030 Warsaw, 55 Pawia Str., room 211, phone: (22) 5365454

e-mail: editorial@ce.vizja.pl

www.ce.vizja.pl

Publisher:

Vizja Press \& IT

$01-029$ Warsaw, 60 Dzielna Str.

phone/fax: (22) 5365468

e-mail: vizja@vizja.pl

www.vizja.net.pl

All articles published in the quarterly are subject to reviews 


\section{WARUNKI ŻYCIA GOSPODARSTW DOMOWYCH}

\subsection{Dochody i sposób gospodarowania dochodami}

4.1.1. Wysokość i zróżnicowanie dochodów gospodarstw domowych oraz nierówności dochodowe Tomasz Panek

Dochody są głównym miernikiem poziomu zamożności gospodarstw domowych i podstawowym czynnikiem warunkującym zaspokojenie ich potrzeb. Prawie zawsze badane populacje gospodarstw domowych składają się z gospodarstw domowych o różnej liczebności i składzie demograficznym, niejednorodnych pod względem potrzeb konsumpcyjnych. Tym samym, aby dochód (wydatki) gospodarstwa domowego prawidłowo spełniał rolę miernika możliwości zaspokojenia potrzeb porównywalnego dla gospodarstw domowych niejednorodnych pod względem potrzeb konsumpcyjnych, powinien on zostać skorygowany ze względu na poziom ich potrzeb. Najprostszym rozwiązaniem jest przyjęcie, że wszystkie osoby w gospodarstwie domowym mają te same potrzeby i korygowanie dochodu gospodarstwa domowego przez jego podzielenie przez liczbę osób w gospodarstwie domowym. Rozwiązanie to posiada jednak dwie zasadnicze wady. Przede wszystkim przyjmuje się tutaj nierealistyczne założenie, że zarówno zakres potrzeb jak i ich poziom, a tym samym wielkość środków pieniężnych potrzebnych na ich zaspokojenie są dla osób dorosłych oraz dzieci w różnym wieku takie same. Ponadto rozwiązanie to pomija występowanie pewnych oszczędności związanych ze wspólnym zamieszkiwaniem i gospodarowaniem członków gospodarstwa domowego (np. wspólne opłacanie czynszu, użytkowanie telewizora, pralki czy też zmywarki). Powoduje to rozkładanie się istotnej części stałych wydatków gospodarstw domowych na większą liczbę osób. Dochody zapewniające zaspokojenie tego samego poziomu potrzeb nie wzrastają tym samym proporcjonalnie do zwiększającej się liczby osób w gospodarstwie. Przykładowo, zapewnienie tego samego poziomu zaspokojenia potrzeb gospodarstwa domowego składającego się z czterech osób jak gospodarstwa domowego jednoosobowego nie wymaga czterokrotnie wyższych wydatków (dochodów). Zjawisko zmniejszania się kosztów jednostkowych funkcjonowania gospodarstwa domowego wraz ze wzrostem jego wielkości nazywane jest zjawiskiem korzyści skali lub też ekonomii skali (Szulc, 2007, s. 139).

O wiele bardziej prawidłowe od korygowania dochodów gospodarstw domowych przez ich dzielenie przez liczbę osób w gospodarstwie jest ich korygowanie przy wykorzystaniu tzw. skal ekwiwalentności. Skale ekwiwalentności są parametrami pozwalającymi na pomiar wpływu wielkości i charakterystyk demograficznych gospodarstw domowych na poziom ich potrzeb, a tym samym na różnice w wielkości dochodów (wydatków) niezbędnych do osiągnięcia tego samego poziomu zaspokojenia potrzeb przez te gospodarstwa domowe. Skala ekwiwalentności dla gospodarstwa domowego danego typu mówi, ile razy należałoby zmniejszyć lub zwiększyć jego dochód, aby osiągnęło ono ten sam poziom zaspokojenia potrzeb, co gospodarstwo standardowe stanowiące punkt odniesienia porównań. Najczęściej takim standardowym gospodarstwem domowym, o skali ekwiwalentności równej 1 , jest gospodarstwo jednoosobowe ${ }^{8}$. W analizie operujemy zarówno kategorią dochodów ekwiwalentnych jak i dochodów na osobę.

Średni dochód netto w marcu 2011 r. wyniósł w badanych gospodarstwach w przeliczeniu na osobę $1295 \mathrm{zl}$ (tabela 4.1.1). Wzrósł on w próbie panelowej w ujęciu realnym w okresie marzec 2007-marzec 2011 o 18 proc. ${ }^{9}$ (wykres 4.1.1). W ostatnich dwóch latach wzrósł natomiast realnie o ok. 4 proc. ${ }^{10}$.

Największe przeciętne dochody netto na osobę w marcu 2011 r. miały gospodarstwa domowe pracujących na własny rachunek (1750 zł na osobę). Kolejnymi grupami gospodarstw domowych o najwyższych przeciętnych dochodach netto na osobę są gospodarstwa domowe pracowników i emerytów (odpowiednio 1355 zł i 1328 zł). Wyraźnie najniższymi przeciętnymi dochodami netto na osobę dysponowały gospodarstwa domowe utrzymujących się z niezarobkowych źródeł (765 zł) i rolników $(827 \text { zł })^{11}$.

\footnotetext{
${ }^{8}$ Sposób szacunku skal ekwiwalentności został przedstawiony w Aneksie 5.

9 Jest to procentowa różnica średnich wielkości dochodu z dwóch pomiarów dla wszystkich gospodarstw. W próbie panelowej można policzyć także średnią procentową zmianę dochodu z dwóch pomiarów dla poszczególnych gospodarstw domowych. W tym drugim przypadku wskaźnik zmiany jest znacznie wyższy (37 proc.). Różnica wynika z „efektu bazy”: w gospodarstwach z niższymi dochodami w pierwszym pomiarze wzrost (spadek) dochodów o pewną wielkość daje znacznie wyższy procentowy wskaźnik zmiany niż w gospodarstwach z wyższym wyjściowo dochodem i jeśli większość zmian na tym indywidualnym poziomie idzie w tym samym kierunku i jest nominalnie zbliżona, a w każdym razie nie w pełni proporcjonalna do wyjściowej wysokości dochodu, to średnia zmiana pozostaje pod większym wpływem zmian w gospodarstwach wyjściowo uboższych, a więc zmian większych procentowo. Przy liczeniu procentowej zmiany średnich dochodów w całej próbie różnice w wyjściowym poziomie dochodów w poszczególnych gospodarstwach nie mają natomiast żadnego znaczenia i zmiany w gospodarstwach wyjściowo uboższych ważą tyle samo co zmiany w gospodarstwach wyjściowo zamożniejszych. Jest sprawą dyskusyjną, która z tych dwóch metod liczenia wskaźnika zmiany daje lepsze informacje o dynamice zmian poziomu zamożności społeczeństwa.

${ }^{10}$ Średnia procentowa zmiana dochodu poszczególnych gospodarstw wynosi w tym przypadku 17 proc. (por. przypis 9 ).

${ }^{11}$ Niskie dochody w tej grupie społeczno-ekonomicznej gospodarstw wynikają częściowo z ich sezonowości.
} 


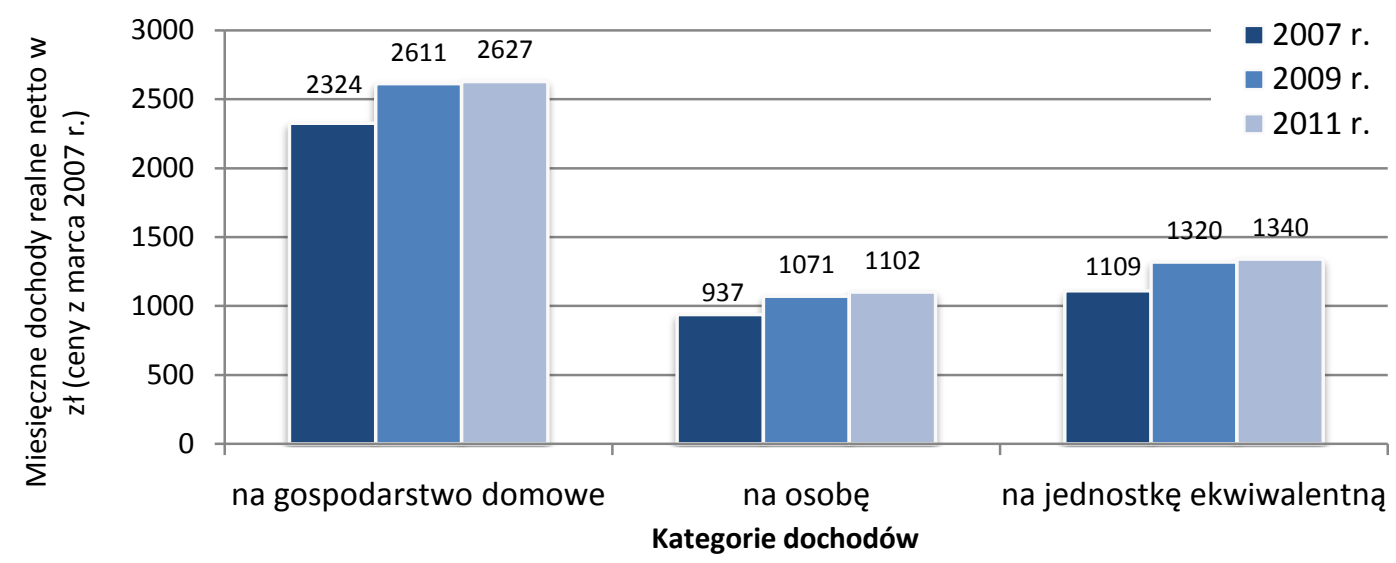

Wykres 4.1.1. Dochody realne netto gospodarstw domowych w latach 2007-2011 w miesiacu poprzedzajacym badanie w próbie panelowej.

Grupami społeczno-ekonomicznymi gospodarstw domowych o najwyższym i najniższym dochodzie ekwiwalentnym (stanowiącym wyznacznik poziomu ich zamożności) są te same grupy jak dla dochodu na osobę. Dochody te dla grup gospodarstw domowych o najwyższym poziomie zamożności wyniosły odpowiednio 2328 zł, 1812 zł i 1425 zł, a dla grupy gospodarstw domowych o najniższym poziomie zamożności 864 zł (tabela 4.1.1). W marcu 2011 r., w stosunku do marca 2009 r., dochody ekwiwalentne netto wzrosły o ok. 3,5 proc. w ujęciu realnym $^{12}$ (tabela 4.1.5). Najsilniej przy tym wzrosły przeciętnie w grupie gospodarstw domowych należących do stosunkowo najmniej zamożnych, a mianowicie rencistów (o około 13,5 proc.).

Dochody netto na jednostkę ekwiwalentną były wyraźnie najniższe w marcu 2011 r. w gospodarstwach domowych małżeństw wielodzietnych oraz rodzin niepełnych (wynosiły one odpowiednio średnio 1229 zł i 1337 zł, tabela 4.1.2). W ostatnich dwóch latach dochody realne na jednostkę ekwiwalentną najsilniej wzrosły w gospodarstwach domowych małżeństw z 1 dzieckiem i bez dzieci oraz w gospodarstwach nierodzinnych wieloosobowych (odpowiednio o prawie 7 i prawie 6 proc.) (tabela 4.1.6).

Dochody netto na jednostkę ekwiwalentną, w gospodarstwach domowych z bezrobotnymi były przeciętnie o około 600 zł niższe niż w gospodarstwach domowych bez bezrobotnych (tabela 4.1.1). W okresie marzec 2009marzec 2011 wzrosły one w ujęciu realnym w grupie gospodarstw domowych z bezrobotnymi o około 8 proc., a w grupie gospodarstw domowych bez bezrobotnych tylko o ok. 3 proc. (tabela 4.1.5).

Tabela 4.1.1. Dochody netto w marcu 2011 r. gospodarstw domowych wedtug grupy społeczno-ekonomicznej i typu aktywności ekonomicznej

\begin{tabular}{lccc}
\hline \multirow{2}{*}{$\begin{array}{c}\text { Grupa społeczno-ekonomiczna i typ } \\
\text { aktywności ekonomicznej }\end{array}$} & \multicolumn{3}{c}{ Dochody netto w zł } \\
\cline { 2 - 4 } & $\begin{array}{c}\text { na gospodarstwo } \\
\text { domowe }\end{array}$ & na osobę & $\begin{array}{c}\text { na jednostkę } \\
\text { ekwiwalentną }\end{array}$ \\
\hline Pracownicy & 3860,71 & 1355,01 & 1811,87 \\
Rolnicy & 3104,34 & 826,89 & 1199,11 \\
Emeryci & 2274,73 & 1328,35 & 1425,02 \\
Renciści & 1683,37 & 996,90 & 1062,75 \\
Pracujący na własny rachunek & 4972,30 & 1750,26 & 2327,64 \\
Utrzymujący się z niezarobkowych źródeł & 1385,99 & 764,71 & 863,50 \\
Bez bezrobotnych & 3234,92 & 1372,85 & 1681,86 \\
Z bezrobotnymi & 2710,63 & 756,23 & 1092,33 \\
\hline Ogółem & 3168,65 & 1294,92 & 1607,30 \\
\hline
\end{tabular}

Dochody na jednostkę ekwiwalentną są wyraźnie w marcu 2011 r. skorelowane z klasą miejscowości zamieszkania. Przeciętne miesięczne dochody na jednostkę ekwiwalentną są tym mniejsze im mniejsza jest miejscowość zamieszkania (w największych miastach wyniosły one przeciętnie w marcu 2011 r. 2337 zł, a na wsi 1273 zł, (tabela 4.1.3). Wyraźnie najniższymi przeciętnymi dochodami na jednostkę ekwiwalentną charakteryzowały się w marcu 2011 r. gospodarstwa domowe zamieszkujące województwa lubelskie oraz świętokrzyskie (odpowiednio 1267 zł i 1310 zł), a najwyższymi mazowieckie i pomorskie (odpowiednio 1998 zł i 1715 zł (tabela 4.1.4). We wszystkich klasach miejscowości zamieszkania (poza wsią) nastąpił znaczący wzrost przeciętnych miesięcznych dochodów realnych na jednostkę ekwiwalentną w ostatnich dwóch latach (tabela 4.1.7). Najsilniej wzrosły one w tym czasie w gospodarstwach domowych zamieszkujących w średniej wielkości miastach o liczbie mieszkanców 100-200 tys. oraz na wsi (odpowiednio o ponad 6 i ok. 5 proc.) Najsilniejszy wzrost tych

\footnotetext{
${ }^{12}$ Wskaźnik ten jest zmianą średnich dla gospodarstw domowych z próby panelowej 2009-2011, czyli gospodarstw, które udało się zbadać dwukrotnie w 2009 i 2011 r.
} 
dochodów w układzie wojewódzkim nastąpił natomiast w grupie gospodarstw domowych zamieszkujących województwo kujawsko-pomorskie oraz podkarpackie (o ok. 10 proc.) (tabela 4.1.8).

Tabela 4.1.2. Dochody netto w marcu 2011 r. gospodarstw domowych wedtug typu gospodarstwa

\begin{tabular}{lccc}
\hline \multirow{2}{*}{ Typ gospodarstwa } & \multicolumn{3}{c}{ Dochody netto w zł } \\
\cline { 2 - 4 } & na gospodarstwo domowe & na osobę & na jednostkę ekwiwalentną \\
\hline Jednorodzinne: & & & 1923,10 \\
Małżeństwa bez dzieci & 3277,61 & 1582,27 & 1855,22 \\
Małżeństwa z 1 dzieckiem & 3974,85 & 1321,11 & 1629,31 \\
Małżeństwa z 2 dzieci & 4178,19 & 1062,87 & 1228,91 \\
Małżeństwa z 3 i więcej dzieci & 3795,85 & 726,08 & 1337,34 \\
Rodziny niepełne & 2574,02 & 1037,93 & 1439,56 \\
Wielorodzinne & 4526,50 & 879,95 & 1493,13 \\
Nierodzinne: & & & 1343,67 \\
Jednoosobowe & 1624,81 & 1622,32 & 1119,67 \\
Wieloosobowe & 2366,70 & & \\
\hline
\end{tabular}

Tabela 4.1.3. Dochody netto gospodarstw domowych w marcu 2011 r. wedtug klasy miejscowości zamieszkania

\begin{tabular}{lccc}
\hline \multicolumn{1}{c}{ Klasa miejscowości } & \multicolumn{3}{c}{ Dochody netto w zł } \\
\cline { 2 - 4 } zamieszkania & na gospodarstwo domowe & na osobę & na jednostkę ekwiwalentną \\
\hline Miasta powyżej 500 tys. & 4176,30 & 1966,34 & 2336,98 \\
Miasta 200-500 tys. & 3290,63 & 1455,51 & 1773,14 \\
Miasta 100-200 tys. & 3144,52 & 1354,21 & 1652,99 \\
Miasta 20-100 tys. & 3067,78 & 1299,73 & 1593,97 \\
Miasta poniżej 20 tys. & 3005,84 & 1184,51 & 1486,96 \\
Wieś & 2818,17 & 969,00 & 1272,76 \\
\hline
\end{tabular}

Tabela 4.1.4. Dochody netto gospodarstw domowych w marcu 2011 r. wedlug województw

\begin{tabular}{lccc}
\hline \multirow{2}{*}{ Województwa } & & Dochody netto w zł & \\
\cline { 2 - 4 } & na gospodarstwo domowe & na osobę & na jednostkę ekwiwalentną \\
\hline Dolnośląskie & 3174,20 & 1333,83 & 1641,05 \\
Kujawsko-pomorskie & 2898,88 & 1169,85 & 1464,32 \\
Lubelskie & 2523,55 & 1021,96 & 1267,27 \\
Lubuskie & 3070,35 & 1249,44 & 1558,86 \\
Łódzkie & 2824,19 & 1202,50 & 1465,59 \\
Małopolskie & 3392,28 & 1331,12 & 1669,71 \\
Mazowieckie & 3794,63 & 1631,57 & 1997,97 \\
Opolskie & 2943,85 & 1167,80 & 1455,44 \\
Podkarpackie & 3120,33 & 1069,25 & 1403,04 \\
Podlaskie & 3051,83 & 1129,53 & 1445,90 \\
Pomorskie & 3383,74 & 1377,32 & 1714,78 \\
Śląskie & 3049,22 & 1312,32 & 1600,53 \\
Świętokrzyskie & 2725,49 & 1035,33 & 1309,99 \\
Warmińsko-mazurskie & 2893,47 & 1135,38 & 1434,66 \\
Wielkopolskie & 3265,40 & 1283,75 & 1616,13 \\
Zachodniopomorskie & 3138,48 & 1318,74 & 1630,81 \\
\hline
\end{tabular}

Tabela 4.1.5. Zmiany realnych dochodów netto z ostatniego miesiaca w okresie marzec 2009-marzec 2011(marzec 2009=100) wedtug grup społeczno-ekonomicznych i typu aktywności ekonomicznej

\begin{tabular}{|c|c|c|c|}
\hline \multirow{2}{*}{$\begin{array}{c}\text { Grupa społeczno-ekonomiczna, } \\
\text { aktywność ekonomiczna } \\
\text { i niepełnosprawność }\end{array}$} & \multicolumn{3}{|c|}{ Dochody netto w ostatnim miesiącu } \\
\hline & na gospodarstwo domowe & na osobę & na jednostkę ekwiwalentną \\
\hline Pracownicy & 102,39 & 102,96 & 102,61 \\
\hline Rolnicy & 110,14 & 104,81 & 106,64 \\
\hline Emeryci & 104,48 & 104,43 & 104,29 \\
\hline Renciści & 114,66 & 113,54 & 113,51 \\
\hline Pracujący na własny rachunek & 102,96 & 101,71 & 101,93 \\
\hline Utrzymujący się z niezarobkowych źródeł & 103,77 & 109,05 & 105,57 \\
\hline Bez bezrobotnych & 102,03 & 103,87 & 102,93 \\
\hline $\mathrm{Z}$ bezrobotnymi & 110,79 & 107,24 & 108,33 \\
\hline Ogółem & 102,93 & 104,25 & 103,48 \\
\hline
\end{tabular}


Tabela 4.1.6. Zmiany dochodów realnych netto gospodarstw domowych w okresie marzec 2009-marzec 2011(marzec 2009=100) wedtug typu gospodarstwa

\begin{tabular}{lccc}
\hline \multicolumn{1}{c}{ Typ gospodarstwa } & \multicolumn{2}{c}{ Dochody netto w ostatnim miesiącu } \\
\cline { 2 - 4 } & na gospodarstwo domowe & na osobę & nednostkę ekwiwalentną \\
\hline Jednorodzinne: & 104,38 & 106,85 & 105,63 \\
Małżeństwa bez dzieci & 104,94 & 108,66 & 106,93 \\
Małżeństwa z 1 dzieckiem & 98,71 & 101,11 & 100,71 \\
Małżeństwa z 2 dzieci & 108,08 & 104,49 & 104,79 \\
Małżeństwa z 3 i więcej dzieci & 98,62 & 99,98 & 100,03 \\
Rodziny niepełne & 102,24 & 102,45 & 102,52 \\
Wielorodzinne & & & 108,35 \\
Nierodzinne: & 103,70 & 106,85 & 100,25 \\
Jednoosobowe & 104,38 & & 105,63 \\
Wieloosobowe & & 103 & \\
\hline
\end{tabular}

Tabela 4.1.7. Zmiany dochodów realnych netto gospodarstw domowych w okresie marzec 2009-marzec 201 (marzec 2009=100) wedtug klasy miejscowości zamieszkania

\begin{tabular}{|c|c|c|c|}
\hline \multirow{2}{*}{$\begin{array}{c}\text { Klasa miejscowości } \\
\text { zamieszkania }\end{array}$} & \multicolumn{3}{|c|}{ Dochody netto w ostatnim miesiącu } \\
\hline & na gospodarstwo domowe & na osobę & na jednostkę ekwiwalentną \\
\hline Miasta powyżej 500 tys. & 102,58 & 103,66 & 102,58 \\
\hline Miasta $200-500$ tys. & 102,11 & 102,54 & 102,36 \\
\hline Miasta $100-200$ tys. & 102,74 & 107,92 & 106,45 \\
\hline Miasta 20-100 tys. & 100,09 & 104,65 & 102,64 \\
\hline Miasta poniżej 20 tys. & 104,16 & 103,08 & 102,93 \\
\hline Wieś & 105,08 & 105,24 & 105,07 \\
\hline
\end{tabular}

Tabela 4.1.8. Zmiany dochodów realnych netto gospodarstw domowych w okresie marzec 2009-marzec 2011(marzec 2009=100) wedtug województw

\begin{tabular}{lccc}
\hline \multirow{2}{*}{ Województwa } & \multicolumn{2}{c}{ Dochody netto w ostatnim miesiącu } \\
\cline { 2 - 4 } & na gospodarstwo domowe & na osobę & na jednostkę ekwiwalentną \\
\hline Dolnośląskie & 100,98 & 104,24 & 102,82 \\
Kujawsko-pomorskie & 110,81 & 110,10 & 110,12 \\
Lubelskie & 99,43 & 104,83 & 102,30 \\
Lubuskie & 103,62 & 107,89 & 106,33 \\
Lódzkie & 100,26 & 102,68 & 101,10 \\
Małopolskie & 103,05 & 104,93 & 104,24 \\
Mazowieckie & 99,92 & 100,71 & 99,92 \\
Opolskie & 97,80 & 97,44 & 95,96 \\
Podkarpackie & 113,27 & 108,86 & 109,80 \\
Podlaskie & 11,65 & 105,42 & 107,40 \\
Pomorskie & 104,06 & 106,75 & 106,49 \\
Śląskie & 106,02 & 106,51 & 106,41 \\
Świętokrzyskie & 105,19 & 99,33 & 101,57 \\
Warmińsko-mazurskie & 104,82 & 103,11 & 102,84 \\
Wielkopolskie & 102,89 & 107,94 & 105,94 \\
Zachodniopomorskie & 95,29 & 101,67 & 98,77 \\
\hline
\end{tabular}

Nierówność rozkładu dochodów gospodarstw domowych została zmierzona współczynnikiem Giniego oraz współczynnikiem zróżnicowania decylowego definiowanym jako stosunek decyla dziewiątego do decyla pierwszego w rozkładzie dochodów ${ }^{13}$. Najbardziej adekwatną kategorią dochodu dla badania nierówności rozkładu dochodów jest tutaj dochód na jednostkę ekwiwalentną, dający podstawy do porównania dochodów gospodarstw o różnym składzie demograficznym.

Nierówność rozkładu dochodów ekwiwalentnych mierzona współczynnikiem Giniego spadła w ostatnich czterech latach w próbie panelowej o 2 proc. (wykres 4.1.2). Podobny spadek, także w próbie panelowej, wystapił w ostatnich dwóch latach (wykres 4.1.3)

\footnotetext{
${ }^{13}$ Współczynnik Giniego przy pomiarze stopnia nierówności rozkładu dochodów bierze pod uwagę udziały dochodów wszystkich gospodarstw domowych w dochodach ogółem. Natomiast współczynnik zróżnicowania decylowego, oceniajacc stopień nierówności rozkładu dochodów, bierze pod uwagę wyłącznie dochody 10 proc. gospodarstw domowych o najniższych dochodach i 10 proc. gospodarstw o najwyższych dochodach, czyli skrajnych grup dochodowych (por. Panek, 2011).
} 


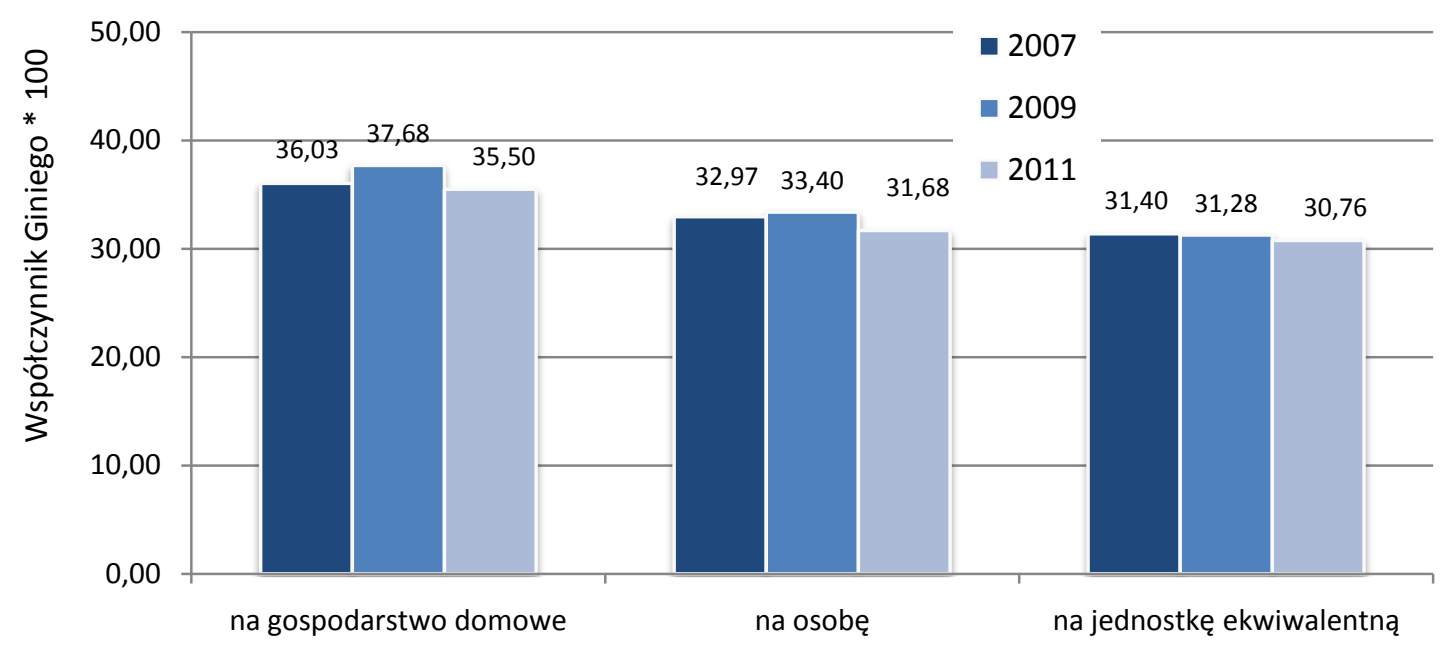

Kategorie dochodów

Wykres 4.1.2. Współczynnik Giniego w 2007, 2009 i 2011 r. w próbie panelowej

Natomiast w okresie marzec 2009-marzec 2011 uległa ona spadkowi o ponad 4 proc. (wykres 4.1.3). Wyniki te zmiany oznaczają, że trend wzrostu nierówności dochodowych obserwowany w latach 90. i na początku obecnego wieku uległ odwróceniu. Podobny trend spadkowy obserwujemy także w stopniu nierówności dochodowych pomiędzy grupą gospodarstw domowych o najwyższych i najniższych dochodach ekwiwalentnych, czyli nierówności pomiędzy skrajnymi grupami dochodowymi gospodarstw domowych w latach 2007-2011. O ile wartość współczynnika zróżnicowania decylowego w marcu 2011 w stosunku do jego wartości w marcu 2007 nie uległa istotnym zmianom to już w okresie marzec 2009-marzec 2011 nastąpił jej spadek o 3 proc.

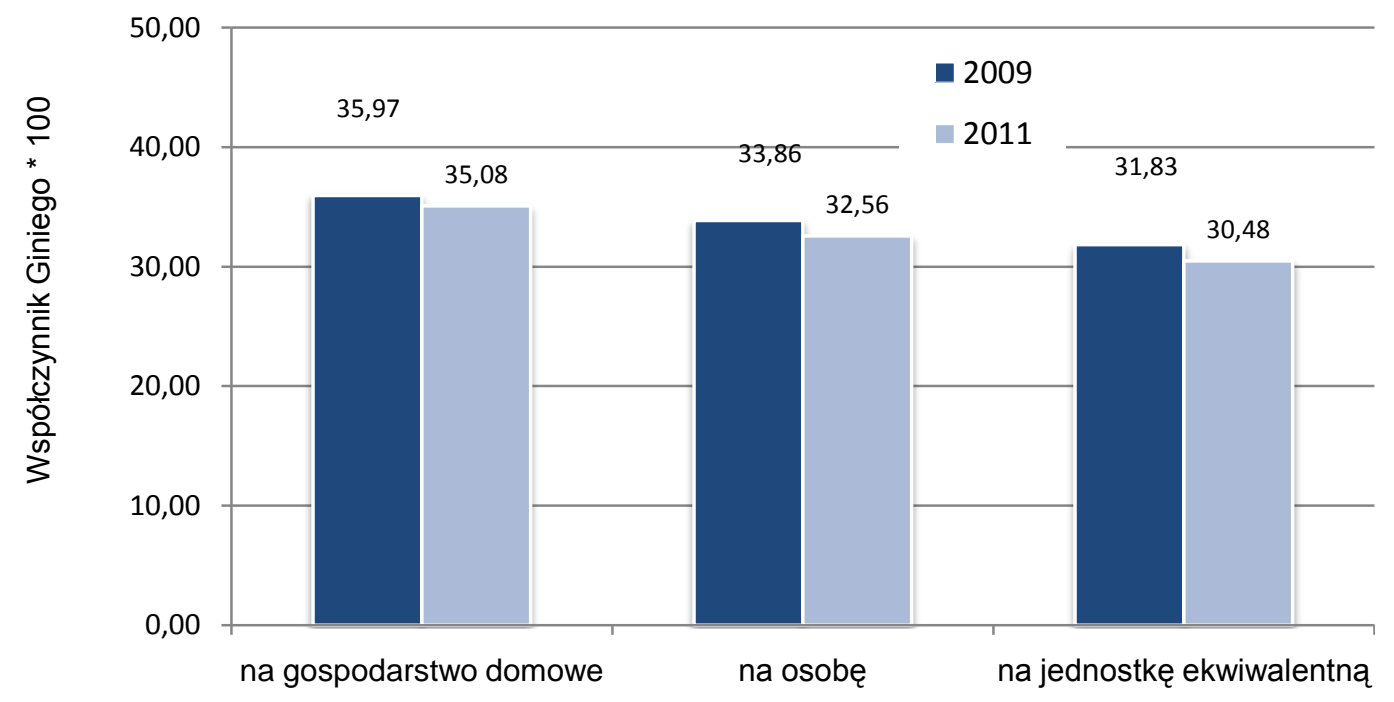

Kategorie dochodów

Wykres 4.1.3. Wspótczynnik Giniego w 2009 i 2011 r. w próbie panelowej.

Najniższy miesięczny dochód netto w zł pozwalający według ocen badanych gospodarstw domowych na powiązanie końca z końcem wynosił w marcu 2011 r. 1347 zł na jednostkę ekwiwalentną. W latach 2007-2011 wzrósł on o 208 zł (wykres 4.1.4), czyli o prawie 20 proc. Aspiracje gospodarstw domowych w zakresie dochodów minimalnych w ujęciu realnym wzrosły w okresie marzec $2007-$ marzec 2011 o prawie 4 proc.

W okresie marzec 2009-marzec 2011 miesięczne dochody ekwiwalentne netto pozwalające na powiązanie gospodarstwom końca z końcem nie zmieniły się istotnie (wykres 4.1.5). Oznacza to jednak spadek aspiracji gospodarstw domowych w ujęciu realnym o około 7 proc. 


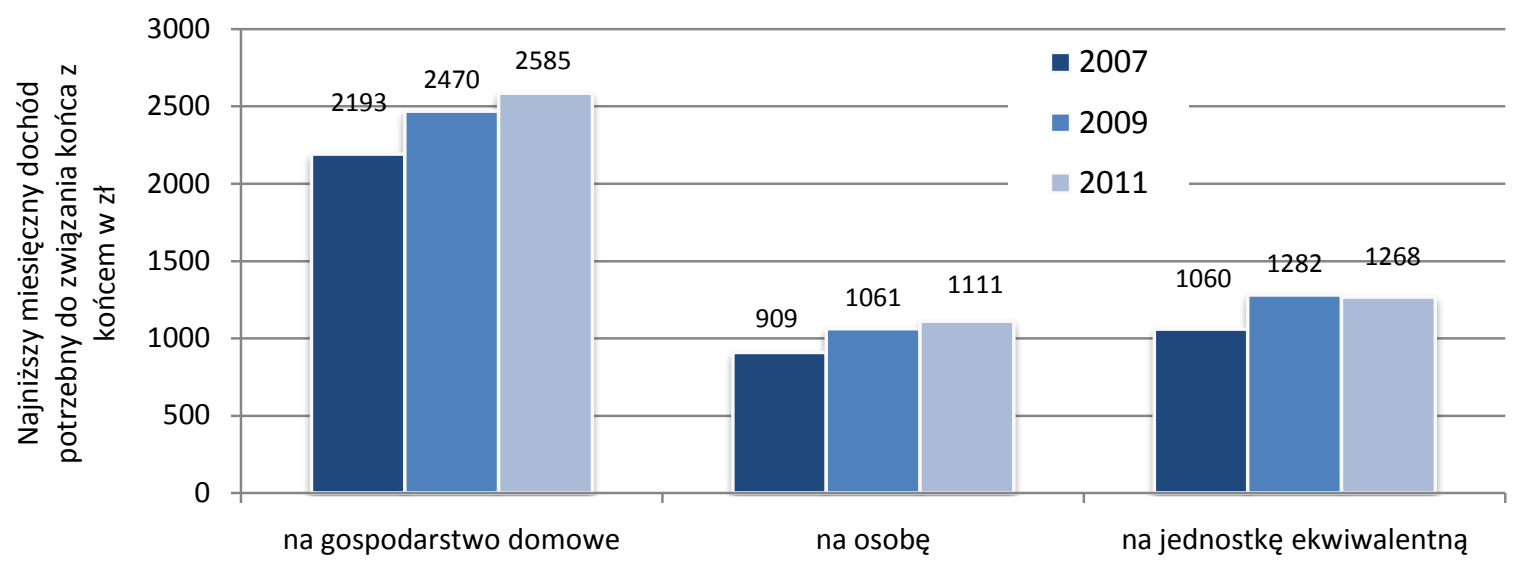

Kategorie dochodów

Wykres 4.1.4. Najniższe miesięczne dochody netto pozwalajace wedtug ocen gospodarstw domowych na powiazanie końca z końcem w latach 2007-2011 w próbie panelowej.

Największe aspiracje odnośnie dochodów ekwiwaletnych pozwalających zaspokoić potrzeby na minimalnym akceptowalnym poziomie miały w marcu 2011 r. gospodarstwa domowe pracujących na własny rachunek i pracowników oraz gospodarstwa małżeństw bez dzieci i małżeństw z 1 dzieckiem (wskazywane przez nich ekwiwalentne dochody minimalne wynosiły odpowiednio 1642 zł, 1428 zl, 1511 zł oraz 1443 zł). W ostatnich dwóch latach nastąpił znaczący wzrost aspiracji dochodowych w ujęciu nominalnym tylko w grupach gospodarstw domowych rolników, gospodarstwach domowych małżęństw z dziećmi oraz rodzin niepełnych. W ujęciu realnym obserwujemy jednak w tym okresie spadek aspiracji dochodowych we wszystkich grupach społecznoekonomicznych i typach gospodarstw domowych. Najniższe aspiracje dochodowe deklarowały w marcu 2011 r. gospodarstwa domowe o najniższych dochodach, czyli gospodarstwa domowe utrzymujących się z niezarobkowych źródeł (1019 zł na jednostkę ekwiwalentną) oraz gospodarstwa domowe małżeństw wielodzietnych (1081 zł).

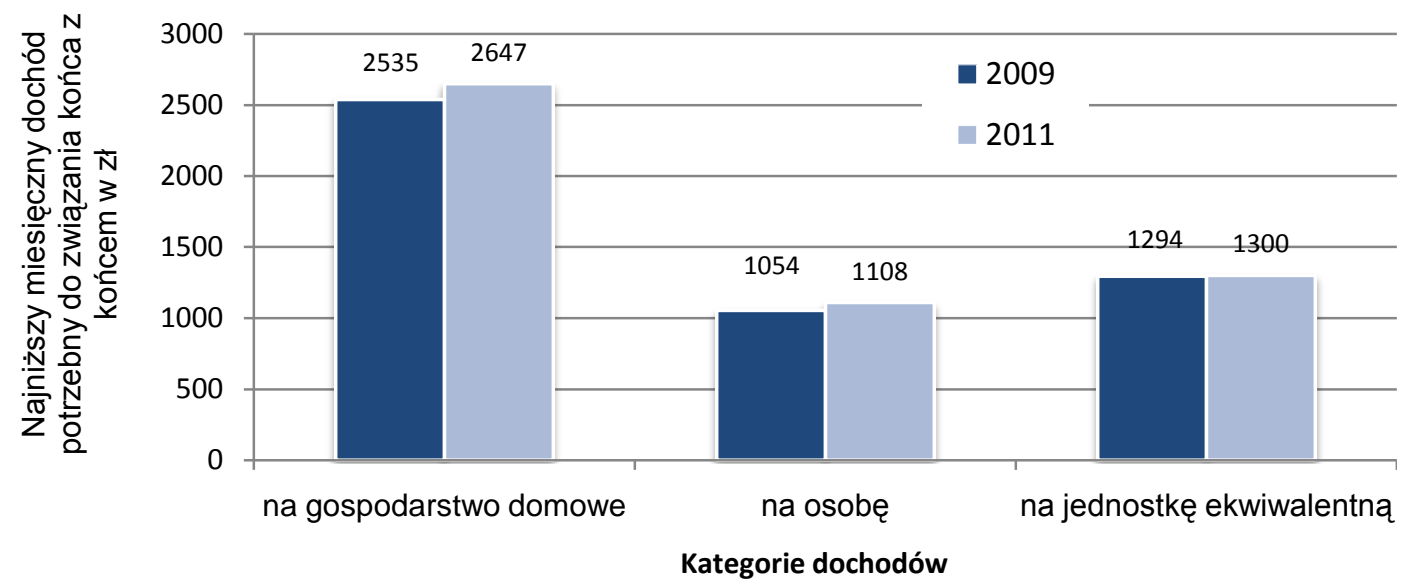

Wykres 4.1.5. Najniższe miesięczne dochody netto pozwalajace wedtug gospodarstw domowych na powiqzanie końca z końcem w 2009 i 2011 r. w próbie panelowej.

Poziom miesięcznych ekwiwalentnych dochodów netto pozwalających na powiązanie końca z końcem deklarowany przez gospodarstwa domowe bez bezrobotnych jest znacząco wyższy niż w przypadku gospodarstw domowych z bezrobotnymi (odpowiednio 1385 zł i 1075 zł). Poziom tych dochodów spadł w ujęciu realnym w marcu 2011 r. w stosunku do marca 2009 r. w obu grupach gospodarstw, chociaż silniej w grupie gospodarstw z bezrobotnymi (o 7 proc.).

Poziom aspiracji w zakresie najniższych miesięcznych dochodów netto pozwalających na powiązanie końca $\mathrm{z}$ końcem generalnie malał wraz ze spadkiem wielkości jednostki zamieszkania. Najniższy poziom miesięcznych dochodów netto na jednostkę ekwiwalentną, pozwalających na powiązanie końca z końcem deklarowały gospodarstwa domowe wiejskie $(1121 \mathrm{zl})$. Natomiast w przekroju regionalnym były to gospodarstwa domowe zamieszkujące województwa podkarpackie, lubelskie i świętokrzyskie (odpowiednio $1003 \mathrm{zl}, 1155 \mathrm{zł}$ oraz $1172 \mathrm{zł}$ na jednostkę ekwiwalentna). W latach 2007-2009 obserwujemy spadek tych aspiracji w ujęciu realnym we wszystkich klasach miejscowości zamieszkania i województwach, przy czym najsilniej w grupach gospodarstw zamieszkujących małe miasta, o liczbie mieszkńców 20-100 tys. oraz województwa dolnośląskie i zachodniopomorskie. 


\subsubsection{Strategie radzenia sobie w trudnej sytuacji finansowej \\ Tomasz Panek}

Najczęściej gospodarstwa domowe deklarowały w marcu 2011 r., że przy aktualnym dochodzie wiązały koniec z końcem z pewną trudnością (prawie 34 proc. gospodarstw), prawie 20 proc. gospodarstw radziło sobie z trudnością, a prawie 18 proc. $\mathrm{z}$ wielką trudnością. $\mathrm{W}$ ostatnich czterech latach znacząco spadł odsetek gospodarstw domowych wiążących koniec z końcem $\mathrm{z}$ wielką trudnością (o ponad 5 p.p, wykres 4.1.6).

W latach 2009-2011 odsetek gospodarstw domowych wiążących koniec z końcem z wielką trudnością spadł tylko o niecały punkt procentowy, czyli nieistotnie (wykres 4.1.7).

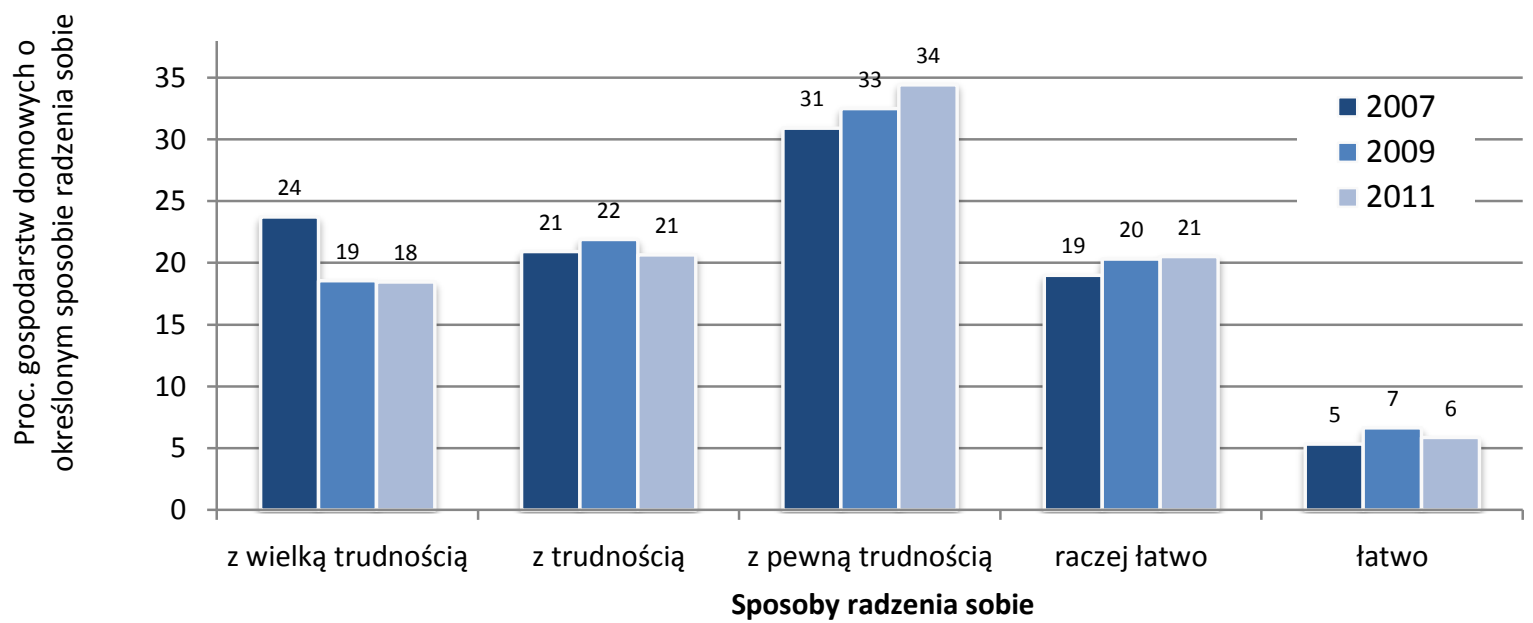

Wykres 4.1.6. Radzenie sobie gospodarstw domowych przy uzyskiwanych dochodach w latach 2007-2011 w próbie panelowej.

Najwyższe odsetki gospodarstw domowych wiążących koniec z końcem z wielką trudnością występowały w marcu 2011 r. w grupie gospodarstw domowych utrzymujących się z niezarobkowych źródeł (prawie 55 proc.) oraz rencistów (ponad 36 proc.). W grupach wyróżnionych ze względu na typ gospodarstwa najliczniej takie gospodarstwa występowały wśród rodzin niepełnych (prawie 28 proc.) oraz gospodarstw nierodzinnych jednoosobowych (prawie 27 proc.). Aż ponad 33 proc. gospodarstw domowych z bezrobotnymi wiązało koniec $\mathrm{z}$ końcem przy aktualnym dochodzie $\mathrm{z}$ wielką trudnością. Natomiast gospodarstwa domowe bez bezrobotnych najczęściej wiązały koniec z końcem z pewną trudnością (prawie 35 proc. gospodarstw w tej grupie). Gospodarstwa wiążące koniec $\mathrm{z}$ końcem przy aktualnych dochodach $\mathrm{z}$ wielką trudnością najczęściej zamieszkiwały wieś i najmniejsze miasta (odpowiednio prawie 21 i ponad 18 proc.) oraz województwo łódzkie (prawie 26 proc.).

W ostatnich 2 latach odsetek gospodarstw domowych wiążących koniec z końcem z wielką trudnością wzrósł znacząco tylko w grupach gospodarstw domowych utrzymujących się z niezarobkowych źródeł (o ponad 2 p.p) oraz gospodarstwach domowych wielorodzinnych i rodzin niepełnych (odpowiednio o ponad 3 i ponad 1 p.p.).

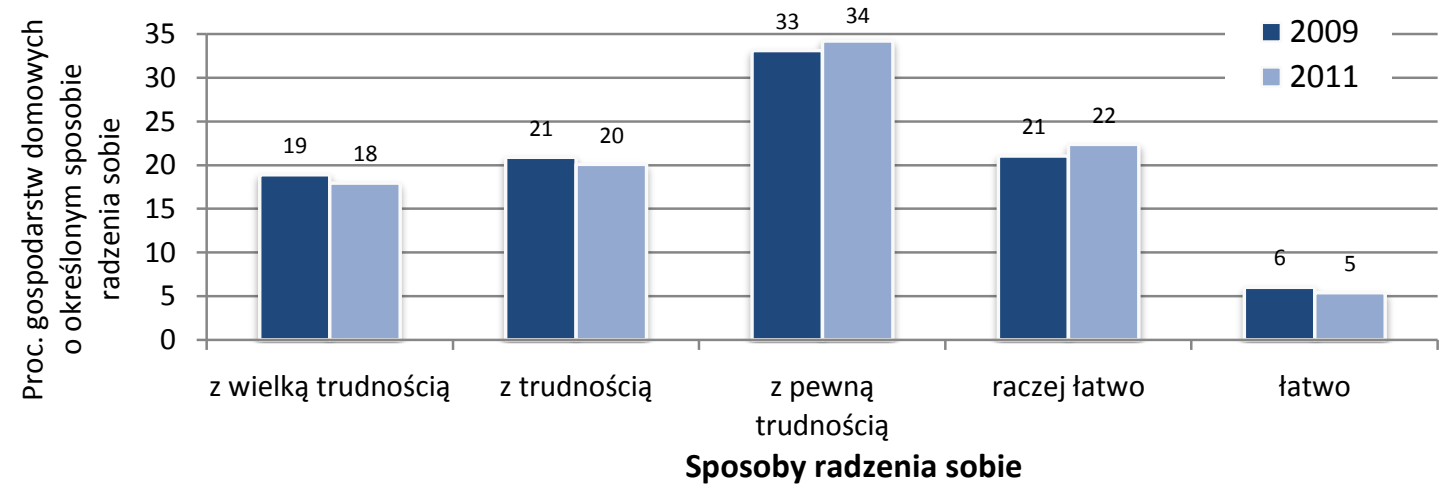

Wykres 4.1.7. Radzenie sobie gospodarstw domowych przy uzyskiwanych dochodach w 2009 i 2011 r. w próbie panelowej.

Oceniając w marcu 2011 r. sposób gospodarowania środkami pieniężnymi, gospodarstwa najczęściej twierdziły, że żyją oszczędnie i dzięki temu starcza im na wszystko (ponad 37 proc. gospodarstw), a następnie, że żyją bardzo oszczędnie, aby odłożyć na poważniejsze zakupy (prawie 21 proc.). Najsilniej wzrósł w ostatnich 4 latach odsetek gospodarstw domowych twierdzących, że żyją oszczędnie, aby odłożyć na najpoważniejsze zakupy oraz, że starcza im na wszystko i jeszcze oszczędzają na przyszłość (odpowiednio o około 6 i o około 3 p.p) (wykres 4.1.8). 
pieniędzy nie starcza nawet na najtańsze jedzenie

starcza na najtańtańsze jedzenie, ale nie starcza na ubranie

starcza na najtańtańsze jedzenie, ubranie, ale nie starcza na mieszkanie

starcza na najtańtańsze jedzenie, ubranie i opłatę za mieszkanie, ale nie starcza na spł kred

starcza na najtańtańsze jedzenie, ubranie i opłatę za mieszkanie oraz spłatę kredyt

żyjemy bardzo oszczędnie aby odłożyć na poważniejsze zakupy

żyjemy oszczędnie i dzięki temu starcza na wszystko

starcza na wszystko bez wyrzeczeń lecz nie oszczędzamy

starcza na wszystko i jeszcze oszczędzamy na przyszłość

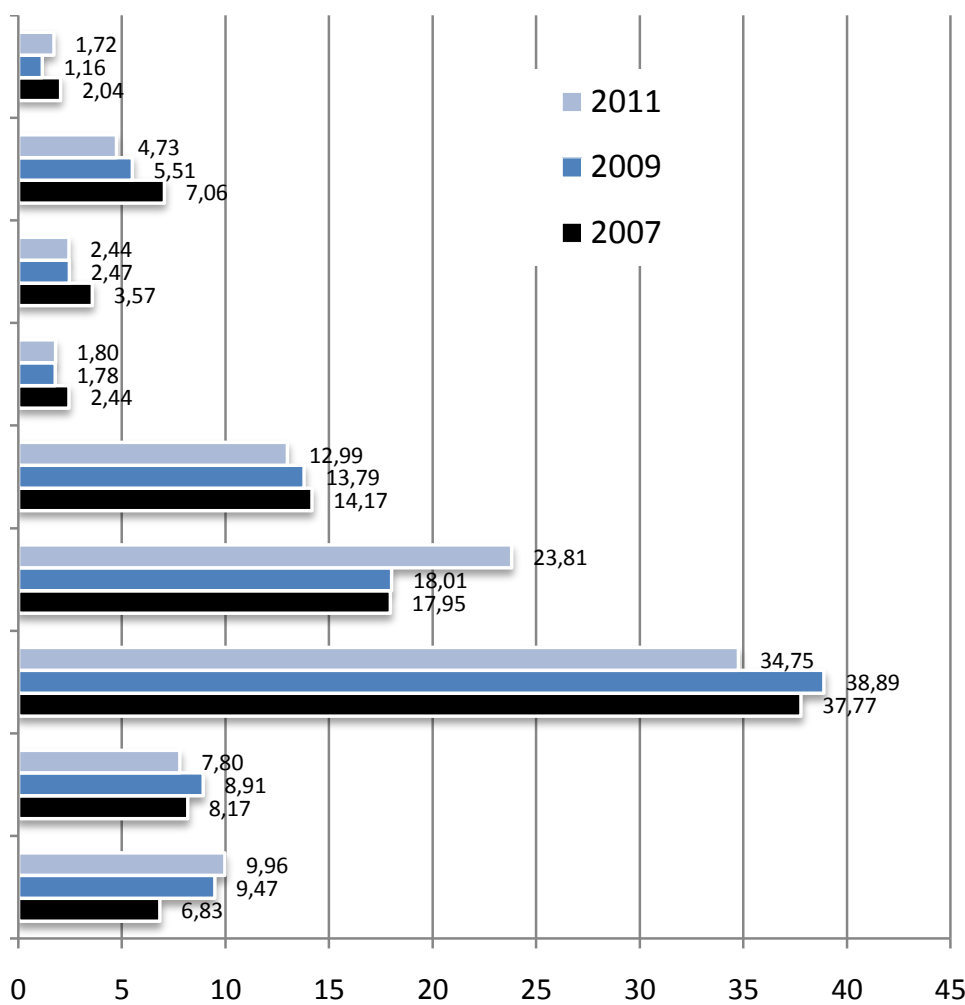

Proc. gospodarstw domowych

Wykres 4.1.8. Sposób gospodarowania dochodem przez gospodarstwa domowe w latach 2007-2011 w próbie panelowej.

W ostatnich dwóch latach znacząco wzrósł odsetek gospodarstw żyjących bardzo oszczędnie, aby odłożyć na poważniejsze zakupy (o ponad 5 p.p) (wykres 4.1.9).

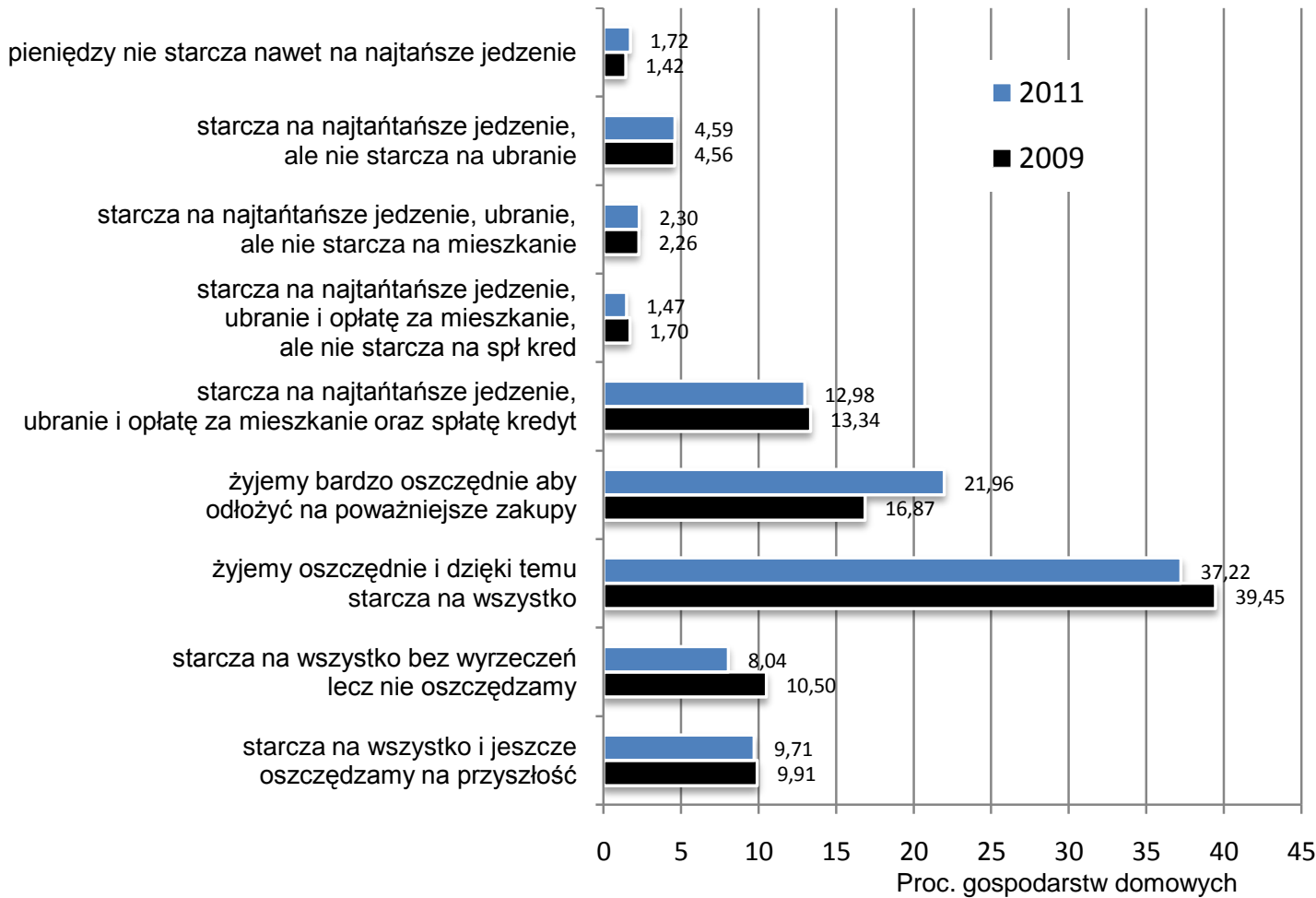

Wykres 4.1.9. Sposób gospodarowania dochodem przez gospodarstwa domowe w 2009 i 2011 r. w próbie panelowej. 
Gospodarstwa twierdzące, że pieniędzy nie starcza im nawet na najtańsze jedzenie (oceniające najgorzej swoją sytuację dochodową), których było w marcu 2011 r. niecałe 2 proc., zdecydowanie najczęściej występowały w grupie gospodarstw utrzymujących się z niezarobkowych źródeł (prawie 14 proc. gospodarstw w tej grupie) oraz gospodarstw nierodzinnych jednoosobowych i rodzin niepełnych (odpowiednio prawie 4 i ponad 2 proc.). Zarówno w grupie gospodarstw z bezrobotnymi, jak i w grupie gospodarstw bez bezrobotnych, najczęściej deklarowano, że żyją oszczędnie i dzięki temu starcza na wszystko (odpowiednio w ponad 32 proc. i w ponad 38 proc. gospodarstw w tych grupach). Jednakże, aż 9 proc. gospodarstw z bezrobotnymi twierdziło, że pieniędzy starcza tylko na najtańsze jedzenie, ale nie starcza na ubranie, a prawie 5 proc., że pieniędzy nie starcza nawet na najtańsze jedzenie. Natomiast w grupie gospodarstw bez bezrobotnych taki sposób gospodarowania dochodem wskazywało odpowiednio tylko prawie 4 proc. i ponad 1 proc. gospodarstw.

Odsetki gospodarstw oceniających najgorzej swoją sytuację dochodową nie były znacząco zróżnicowane w grupach wyróżnionych ze względu na klasę miejscowości zamieszkania i województwo. Relatywnie najwyższy odsetek gospodarstw domowych wskazujących, że pieniędzy nie starcza nawet na najtańsze jedzenie występował w miastach o liczbie mieszkańców 100-200 tys. (ponad 3 proc.) i na wsi (około 2 proc.). Województwami o relatywnie największej częstotliwości występowania gospodarstw oceniających najgorzej swoją sytuację dochodową były warmińsko-mazurskie i lubuskie (po około 5 proc.). Odsetek gospodarstw domowych twierdzących, że pieniędzy nie starcza nawet na najtańsze jedzenie nie uległ istotnym zmianom w ostatnich 2 latach. Wzrost tych pesymistycznych ocen w ostatnich 2 latach nastąpił jedynie w grupie gospodarstw domowych utrzymujących się $\mathrm{z}$ niezarobkowych źródeł (o prawie 3 p.p). Nieznaczny wzrost odsetka gospodarstw domowych oceniających najbardziej pesymistycznie sposób gospodarowania dochodem wystąpił ponadto w grupach gospodarstw zamieszkujących województwa warmińsko-mazurskie i lubuskie (odpowiednio o prawie 4 i prawie 2 p.p).

Około 26 proc. gospodarstw deklarowało w marcu 2011 r., że ich stałe dochody nie pozwalają na zaspokojenie bieżących potrzeb. W ostatnich w czterech latach odsetek gospodarstw domowych, których dochody nie pozwalają na zaspokojenie bieżących potrzeb spadł o ponad 5 p.p. (wykres 4.1.10).

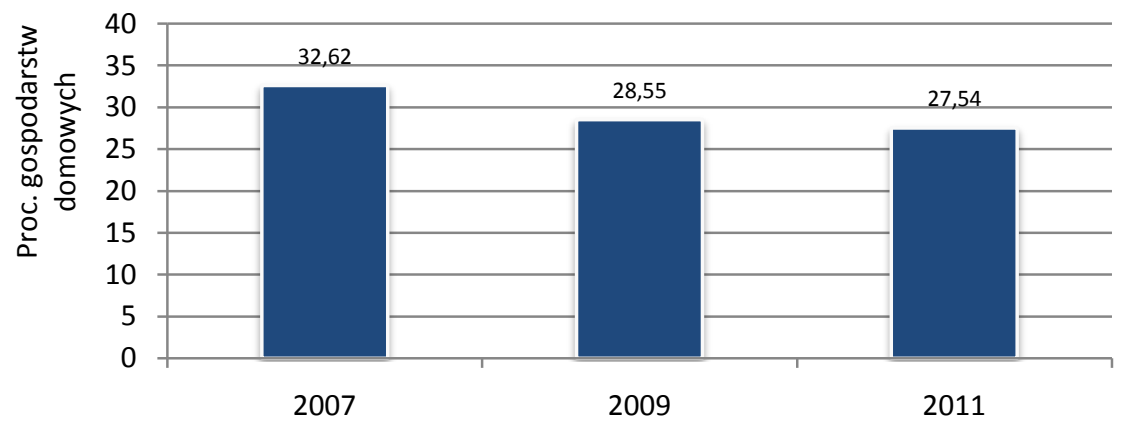

Wykres 4.1.10. Procent gospodarstw domowych, których stałe dochody nie pozwalaja na zaspokojenie bieżacych potrzeb w latach 2007-2011 w próbie panelowej.

Natomiast w ostatnich dwóch latach spadek ten wyniósł ponad 1 p.p. (wykres 4.1.11). Gospodarstwa domowe deklarujące, że ich stałe dochody nie pozwalają na zaspokojenie bieżących potrzeb najczęściej występowały w marcu 2011 r. w grupach gospodarstw domowych utrzymujących się z niezarobkowych źródeł (ponad 68 proc. gospodarstw) i rencistów (prawie 48 proc. gospodarstw) oraz w grupach gospodarstw rodzin niepełnych (ponad 34 proc.) i nierodzinnych jednoosobowych (około 35 proc. gospodarstw). W grupie gospodarstw domowych $\mathrm{z}$ bezrobotnymi tego typu deklaracje złożyło ponad 44 proc. gospodarstw, podczas gdy w grupie gospodarstw bez bezrobotnych tylko nieco ponad 23 proc. gospodarstw.

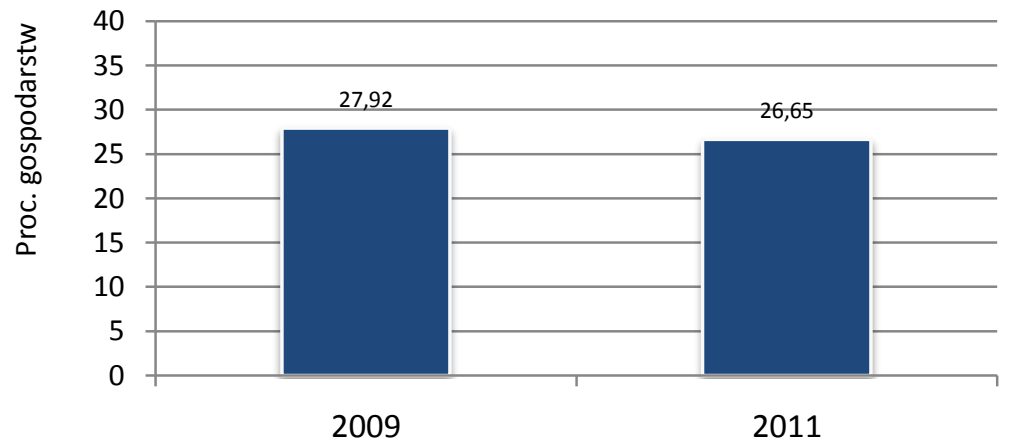

Wykres 4.1.11. Procent gospodarstw domowych, których stałe dochody nie pozwalaja na zaspokojenie bieżacych potrzeb w 2009 i 2011 r. w próbie panelowej. 
Gospodarstwa domowe, których stałe dochody nie pozwalają na zaspokojenie bieżących potrzeb, najczęściej zamieszkiwały wieś (około 29 proc. gospodarstw) oraz województwa warmińsko-mazurskie i łódzkie (odpowiednio ponad 35 proc. i prawie 31 proc. gospodarstw).

W latach 2009-2011 odsetek gospodarstw domowych twierdzących, że ich stałe dochody nie pozwalają na zaspokojenie bieżących potrzeb, wzrósł znacząco tylko w grupach gospodarstw utrzymujących się $\mathrm{Z}$ niezarobkowych źródeł (wzrost o prawie 3 p.p), zamieszkujących największe miasta (wzrost o prawie 4 p.p) oraz województwa opolskie i mazowieckie (wzrost odpowiednio o prawie 3 i o ponad 1 p.p.).

Gospodarstwa domowe w marcu 2011 r. najczęściej deklarowały, że w sytuacjach, gdy ich dochody nie pozwalają na zaspokojenie bieżących potrzeb, ograniczają swoje bieżące potrzeby (ponad 86 proc. gospodarstw ze zbyt małym dochodem) lub korzystają z pomocy krewnych (ponad 37 proc. gospodarstw), bądź też zaciągają pożyczki (prawie 31 proc. gospodarstw). Tylko w około 16 proc. gospodarstw znajdujących się w takiej sytuacji członek gospodarstwa podejmuje dodatkową pracę. W ostatnich czterech latach relatywnie najbardziej zwiększył się odsetek gospodarstw domowych, które w sytuacjach, gdy ich dochody nie pozwalały na zaspokojenie ich bieżących potrzeb, ograniczały swoje bieżące potrzeby, lub też ich członkowie podejmowali dodatkową pracę (po ponad 2 p.p, wykres 4.1.12). Jednocześnie najsilniej spadł w tym okresie odsetek gospodarstw, które w takiej sytuacji zaciągały pożyczki lub brały kredyty (o około 8 p.p).

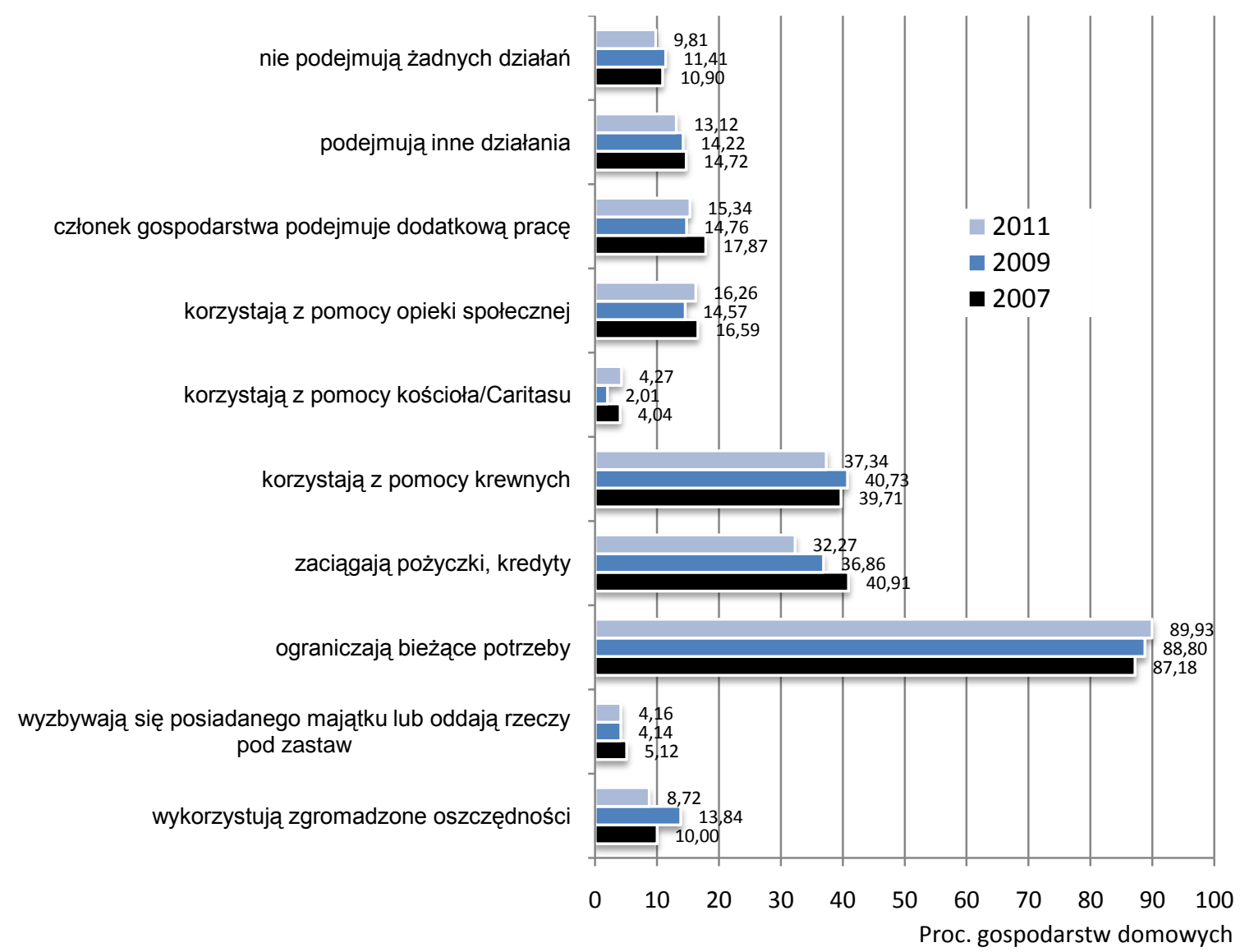

Wykres 4.1.12. Działania podejmowane przez gospodarstwa domowe, gdy ich stałe dochody nie pozwalaja na zaspokojenie bieżacych potrzeb w latach 2007-2011 w próbie panelowej.

W latach 2009-2011 najsilniej wzrósł odsetek gospodarstw domowych, które w sytuacji, gdy ich bieżące dochody nie pozwalały na zaspokojenie bieżących potrzeb, ograniczały swoje potrzeby lub też korzystały z pomocy kościoła lub opieki społecznej (o ponad 1 p.p. dla każdego z tych typów działań). Relatywnie najsilniej spadły odsetki gospodarstw, które w takiej sytuacji wykorzystywały zgromadzone oszczędności lub zaciagały pożyczki, kredyty (odpowiednio o ponad 4 i prawie 3 p.p, wykres 4.1.13). 


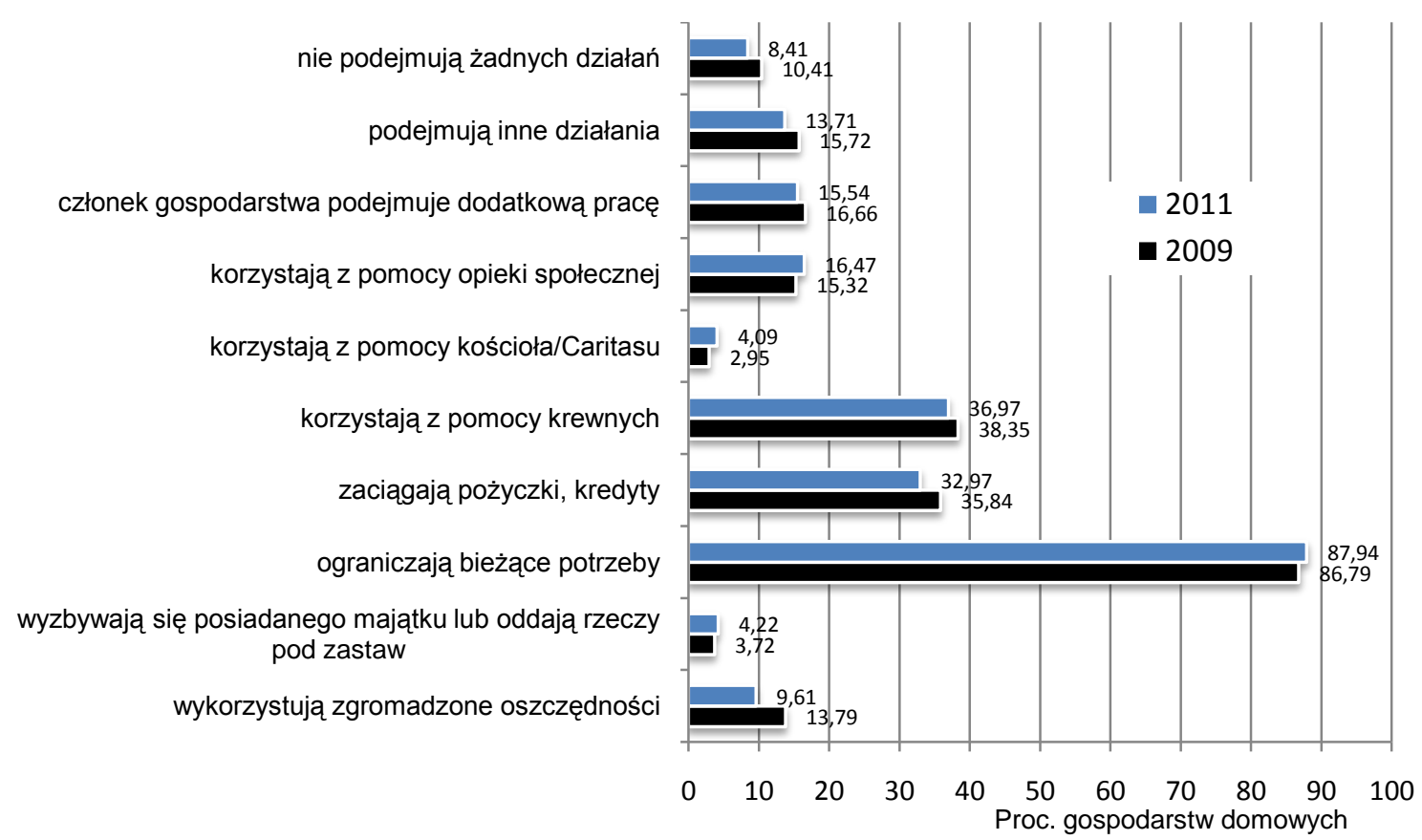

Wykres 4.1.13. Działania podejmowane przez gospodarstwa domowe, gdy ich stałe dochody nie pozwalaja na zaspokojenie bieżacych potrzeb w 2009 i 2011 r. w próbie panelowej.

Zróżnicowanie pomiędzy grupami gospodarstw, wyróżnionymi ze względu na wszystkie zastosowane w badaniu kryteria, deklarujących ograniczanie bieżących potrzeb w przypadku zbyt niskich dochodów, nie było zbyt duże. Najczęściej, w marcu 2011 r., zaciaggały pożyczki, gdy ich stałe dochody nie pozwalały na zaspokojenie bieżących potrzeb, gospodarstwa domowe rolników i pracowników (około 40 proc. gospodarstw z tych grup) oraz gospodarstwa wielorodzinne (ponad 44 proc. gospodarstw). Tego typu zachowania występowały także najczęściej wśród gospodarstw zamieszkujących małe miasta, o liczbie mieszkańców 10-100 tys. (ponad 35 proc. gospodarstw) oraz województwa kujawsko-pomorskie i dolnoślaskie (prawie 44 proc. gospodarstw i prawie 43 proc. gospodarstw).

W marcu 2011 r. korzystanie z pomocy krewnych, w sytuacjach, gdy stałe dochody nie pozwalały na zaspokojenie bieżących potrzeb, charakteryzowało przede wszystkim gospodarstwa domowe utrzymujących się z niezarobkowych źródeł (prawie 54 proc.) oraz gospodarstwa nierodzinne jednoosobowe (ponad 44 proc.). Gospodarstwa postępujące w powyższy sposób najczęściej zamieszkiwały największe miasta (prawie 40 proc.) oraz województwa kujawsko-pomorskie (prawie 45 proc. gospodarstw) i mazowieckie (prawie 43 proc. gospodarstw).

W sytuacji, gdy stałe dochody nie pozwalały na zaspokojenie bieżących potrzeb, zarówno gospodarstwa domowe $\mathrm{z}$ bezrobotnymi jak i gospodarstwa domowe bez bezrobotnych najczęściej reagowały w podobny sposób jak grupy gospodarstw wyodrębnione według innych kryteriów typologicznych. Zwraca natomiast uwagę o wiele większa częstotliwość korzystania $\mathrm{w}$ takich sytuacjach, $\mathrm{w}$ grupie gospodarstw $\mathrm{z}$ bezrobotnymi niż $\mathrm{w}$ grupie gospodarstw bez bezrobotnych, z pomocy opieki społecznej (odpowiednio prawie 33 i zaledwie niecałe 12 proc. gospodarstw z tych grup korzystało $\mathrm{z}$ tej formy pomocy).

Aktywny sposób działań podejmowanych w sytuacji, gdy stałe dochody nie pozwalały na zaspokojenie bieżących potrzeb, tj. podejmowanie dodatkowej pracy przez członka gospodarstwa, preferowały relatywnie najczęściej gospodarstwa domowe pracowników (ponad 25 proc.) oraz małżeństw wielodzietnych i małżeństw z 2 dzieci (odpowiednio ponad 28 i prawie 28 proc.), natomiast najrzadziej gospodarstwa emerytów i rencistów (odpowiednio prawie 7 proc. i ponad 9 proc.) oraz gospodarstwa nierodzinne. Gospodarstwa preferujące tego typu działania zamieszkiwały najczęściej duże miasta o liczbie mieszkańców 200-500 tys. (ponad 20 proc. gospodarstw) oraz województwa podlaskie i lubelskie (odpowiednio ponad 24 proc. i ponad 23 proc. gospodarstw).

Ponad 27 proc. gospodarstw domowych oceniało w marcu 2011 r., że ich sytuacja dochodowa w porównaniu do sytuacji sprzed 2 lat pogorszyła się, a prawie 62 proc., że nie zmieniła się. Odsetek pesymistycznych ocen zmian był przy tym o prawie 9 p.p. niższy niż w 2009 r. Pesymistyczna ocena zmian najczęściej była formułowana wśród gospodarstw domowych utrzymujących się z niezarobkowych źródeł (prawie 50 proc.) oraz gospodarstw rodzin niepełnych i małżeństw wielodzietnych (odpowiednio ponad 36 i ponad 34 proc.). W grupie gospodarstw domowych z bezrobotnymi ponad 47 proc. twierdziło, że ich sytuacja dochodowa pogorszyła się. Natomiast $\mathrm{w}$ grupie gospodarstw bez bezrobotnych takie deklaracje składało tylko niecałe 25 proc. Gospodarstwa uważające, że ich sytuacja dochodowa w porównaniu do sytuacji sprzed 2 lat pogorszyła się, najczęściej zamieszkiwały wieś (prawie 31 proc.) oraz województwa lubuskie (prawie 33 proc.) i lubelskie (ponad 30 proc. gospodarstw). 


\subsubsection{Zmiana strategii radzenia sobie $w$ dtuższym okresie Janusz Czapiński}

W ostatnich 11 latach znacząco spadł odsetek gospodarstw domowych wiążących koniec z końcem z wielką trudnością i z trudnością (odpowiednio o 13 i 5 p.p.), a wzrósł -- radzących sobie raczej łatwo i łatwo (odpowiednio o 11 i 3 p.p.) (wykres 4.1.14).

Najsilniej wzrósł w ostatnich 11 latach odsetek gospodarstw domowych twierdzących, że żyją oszczędnie i dzięki temu starcza im na wszystko (o 10 p.p). Wzrósł także 07 p.p. odsetek gospodarstw, którym starcza na wszystko i jeszcze oszczędzają na przyszłość, zmalał natomiast procent gospodarstw w najtrudniejszej sytuacji, którym pieniędzy nie starcza na spłatę kredytu, opłaty za mieszkanie czy na ubranie (wykres 4.1.15). Wzrósł ponownie do poziomu z 2000 r. odsetek gospodarstw żyjących bardzo oszczędnie z myślą o poważniejszych zakupach.

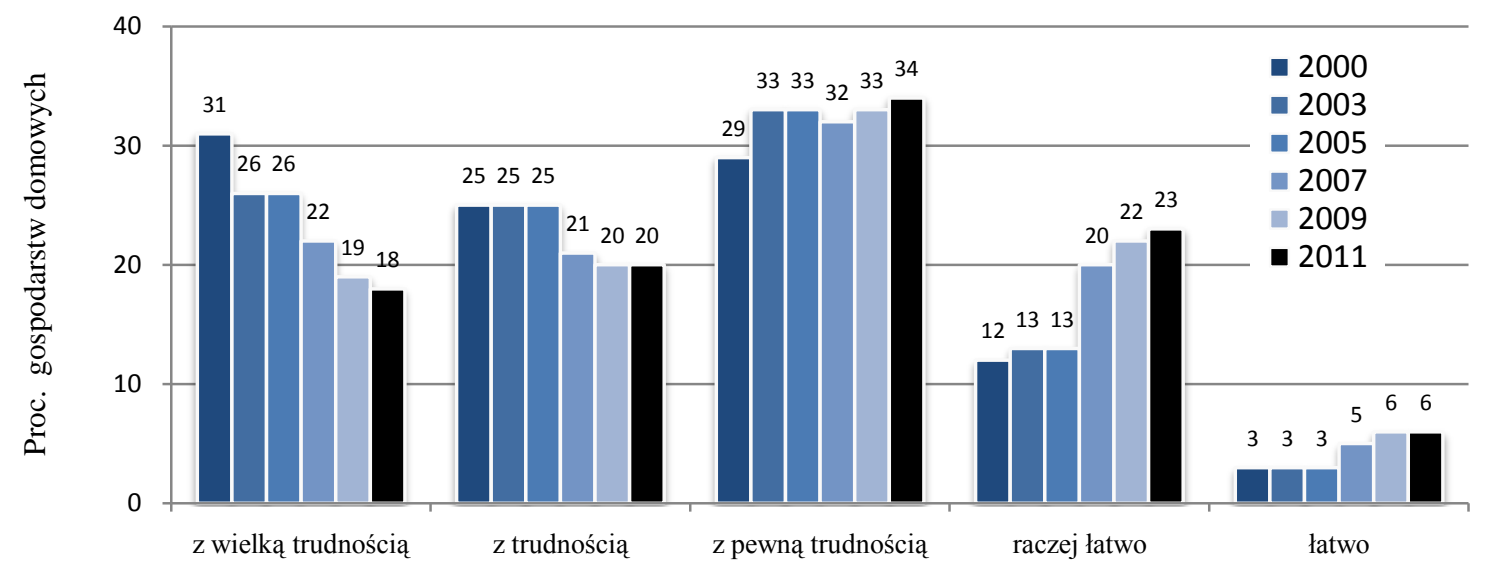

Jak sobie radzą

Wykres 4.1.14. Radzenie sobie gospodarstw domowych przy uzyskiwanych dochodach w latach 2000-2011 w catych próbach

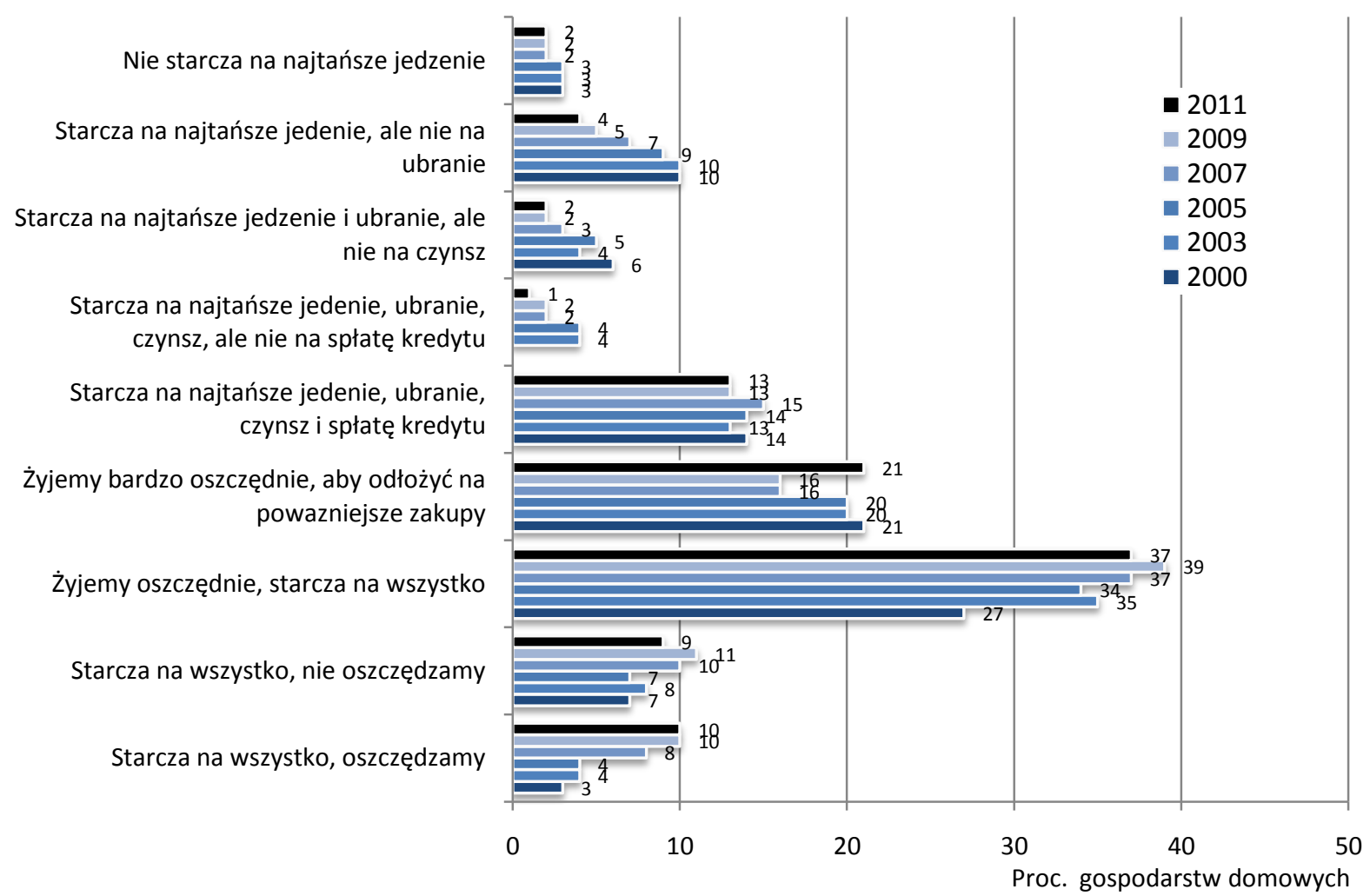

Wykres 4.1.15. Sposób gospodarowania dochodem przez gospodarstwa domowe w latach 2000-2011 w całych próbach 
Niecałe 26 proc. gospodarstw deklarowało w marcu/kwietniu 2011 r., że ich stałe dochody nie pozwalają na zaspokojenie bieżących potrzeb. W ostatnich dwóch latach odsetek gospodarstw domowych, których dochody nie pozwalają na zaspokojenie bieżących potrzeb, spadł o 2 p.p., a od 1993 r. spadek był niemal trzykrotny (wykres 4.1.16).

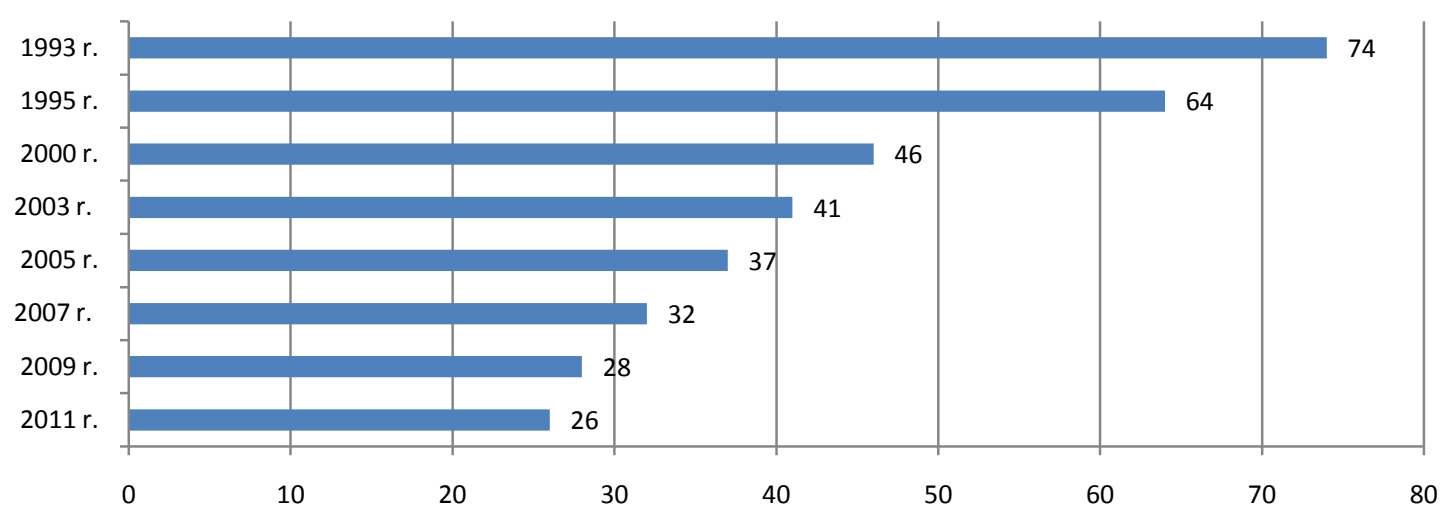

Źródło danych: lata 1993-1997 — Czapiński, 1998; lata 2000-2011 — Diagnoza Społeczna.

Wykres 4.1.16. Odsetek gospodarstw domowych deklarujacych, że ich stałe dochody nie pozwalaja na zaspokojenie bieżacych potrzeb w latach 1993-2011 w catych próbach

W okresie od 1993 r. spadł odsetek gospodarstw, które w w warunkach niewystarczających stałych dochodów ograniczały potrzeby, podejmowały dodatkową pracę, korzystały z oszczędności lub zaciągały pożyczki (tabela 4.1.9). Spadł również odsetek gospodarstw bezradnych, które w sytuacji kłopotów finansowych nie podejmują żadnych działań. Wzrósł natomiast odsetek gospodarstw, które w takiej sytuacji korzystały z pomocy zewnętrznej (głównie z pomocy opieki społecznej).

Tabela 4.1.9. Odsetek gospodarstw domowych deklarujacych różne sposoby reagowania na finansowe trudności w zaspokojeniu bieżacych potrzeb spośród tych, w których stałe dochody nie pozwalaja na zaspokojenie bieżcych potrzeb, $w$ calych ważonych próbach $w$ latach 1993-2011*

\begin{tabular}{|c|c|c|c|c|c|c|c|c|}
\hline $\begin{array}{l}\text { Sposoby radzenia sobie } \mathrm{z} \\
\text { trudnościami finansowymi }\end{array}$ & $\begin{array}{c}1993 \\
\mathrm{~N}=1700 \\
\end{array}$ & $\begin{array}{c}1995 \\
\mathrm{~N}=1940 \\
\end{array}$ & $\begin{array}{c}2000 \\
\mathrm{~N}=1350\end{array}$ & $\begin{array}{c}2003 \\
\mathrm{~N}=1579 \\
\end{array}$ & $\begin{array}{c}2005 \\
\mathrm{~N}=1598\end{array}$ & $\begin{array}{c}2007 \\
\mathrm{~N}=1745\end{array}$ & $\begin{array}{c}2009 \\
\mathrm{~N}=3433\end{array}$ & $\begin{array}{c}2011 \\
\mathrm{~N}=3100\end{array}$ \\
\hline Ograniczanie potrzeb & 93,3 & 88,8 & 88,7 & 92,5 & 89,5 & 89,2 & 86,4 & 86,2 \\
\hline Podejmowanie dodatkowej pracy & 29,4 & 32,9 & 22,9 & 22,1 & 21,5 & 18,1 & 16,3 & 16,3 \\
\hline Korzystanie z oszczędności & 20,8 & 15,1 & 16,6 & 9,5 & 8,5 & 7,6 & 13,0 & 9,7 \\
\hline Zaciąganie pożyczek & 43,3 & 44,6 & 50,7 & 42,9 & 42,0 & 40,9 & 35,5 & 32,2 \\
\hline Korzystanie z pomocy krewnych & 44,7 & 42,9 & 40,3 & 35,5 & 39,1 & 39,5 & 38,9 & 37,1 \\
\hline Korzystanie z pomocy Kościoła & 1,0 & 0,8 & 1,3 & 0,7 & 1,9 & $3,4^{* *}$ & $3,3^{* *}$ & $3,9^{* *}$ \\
\hline $\begin{array}{l}\text { Korzystanie z pomocy opieki } \\
\text { społecznej }\end{array}$ & 7,5 & 7,1 & 11,7 & 13,4 & 16,2 & 16,7 & 15,5 & 16,6 \\
\hline Wyzbywanie się majątku & b.d. & b.d. & 5,7 & 6,9 & 5,9 & 4,4 & 4,5 & 4,6 \\
\hline Podejmowanie innych działań & b.d. & b.d. & 19,0 & 20,3 & 23,4 & 16,6 & 16,2 & 15,3 \\
\hline Niepodejmowanie żadnych działań & b.d. & b.d. & 13,1 & 12,6 & 11,3 & 9,8 & 10,7 & 8,1 \\
\hline
\end{tabular}

* w stosunku do gospodarstw, których dochody nie pozwalają na zaspokojenie bieżących potrzeb

** od 2007 r. ,,z pomocy Kościoła/Caritasu”

Źródło danych: lata 1993-1997 — Czapiński, 1998; lata 2000-2011 — Diagnoza Społeczna

\subsubsection{Pomoc spoleczna Janusz Czapiński}

Odsetek gospodarstw otrzymujących pomoc zewnętrzną w dowolnej formie wyniósł 10,9 proc., a więc prawie tyle samo co dwa lata temu (10,7 proc.). Wzrósł jednak w stosunku do poziomu z początku wieku odsetek gospodarstw otrzymujących wszystkie trzy formy pomocy: finansową z 8 do 10,2 proc., rzeczową z 4,9 do 6,3 proc. i w formie usług z 2,6 do 3,8 proc. (wykres 4.1.17).

Zasięg pomocy jest silnie zróżnicowany według grup społeczno-ekonomicznych, typu gospodarstwa i województwa.

Gospodarstwa nierodzinne wieloosobowe i jednoosobowe, małżeństwa z trójką i większą liczbą dzieci oraz rodziny niepełne korzystały znacznie częściej z pomocy społecznej niż pozostałe grupy gospodarstw (odpowiednio 21,7, 14,6, 13 i 11,7 proc.). Najrzadziej z pomocy korzystały małżeństwa bez dzieci (7,3 proc.) i małżeństwa z jednym dzieckiem (7,1 proc.) (wykres 4.1.18). Znacząco zmniejszył się zasięg pomocy dla rodzin niepełnych 
(spadek o 19 proc.); zwiększył się natomiast zakres pomocy dla gospodarstw jednoosobowych (wzrost o 30 proc.) i dla gospodarstw nierodzinnych wieloosobowych (wzrost o 14 proc.) (wykres 4.1.19).

Z pomocy zewnętrznej korzystało niemal 40 proc. gospodarstw o niezarobkowym źródle utrzymania i co szóste gospodarstwo rencistów; najmniejszy odsetek korzystających z pomocy jest w grupie gospodarstw rolników (5,5 proc.) i pracujących na własny rachunek $(8,8$ proc.). Niemal tyle samo gospodarstw pracowników $(9,2$ proc.) i emerytów (9,3 proc.) korzysta z pomocy zewnętrznej (wykres 4.1.20).

Jedynie w grupie gospodarstw utrzymujących się ze źródeł niezarobkowych nastąpił w ostatnich dwóch latach spadek zakresu korzystania z pomocy zewnętrznej (53 do 47 proc.). Niewielki wzrost wystąpi w grupie gospodarstw emerytów (wykres 4.1.21).

Częściej z pomocy zewnętrznej korzystały gospodarstwa miejskie (zwłaszcza z miast do 500 tys.) niż wiejskie (wykres 4.1.22). Absolutny rekord $\mathrm{w}$ zakresie korzystania $\mathrm{z}$ pomocy zewnętrznej pobiły najbiedniejsze gospodarstwa z miast średniej wielkości (100-200 tys. - 40 proc. korzystających)

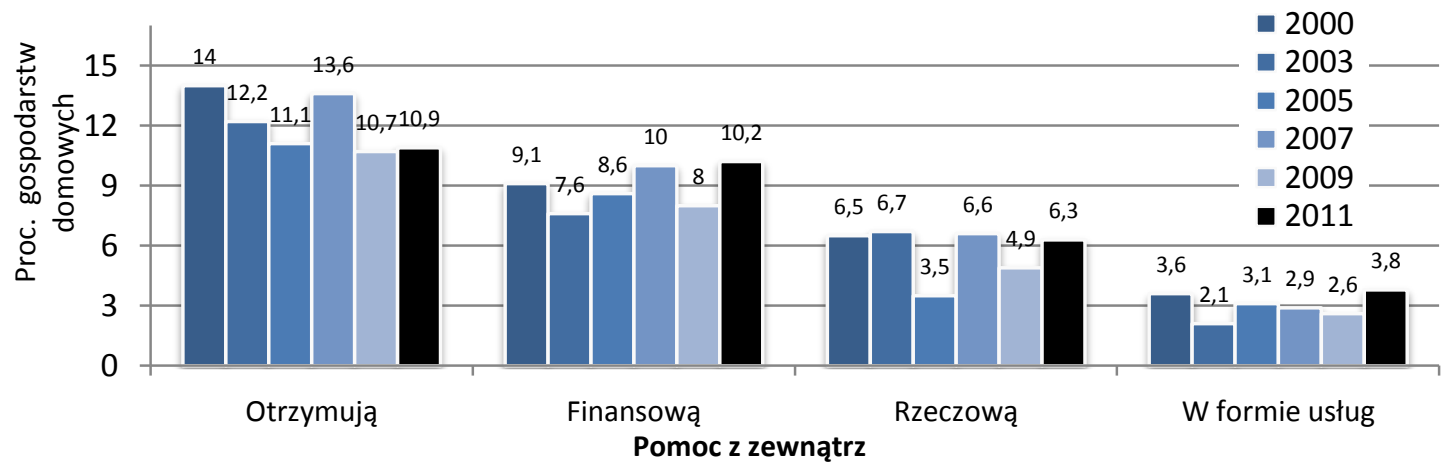

Wykres 4.1.17. Odsetek gospodarstw domowych otrzymujacych pomoc z zewnatrz i gospodarstw otrzymujacych określony rodzaj pomocy w latach 2000-2011 w catych próbach

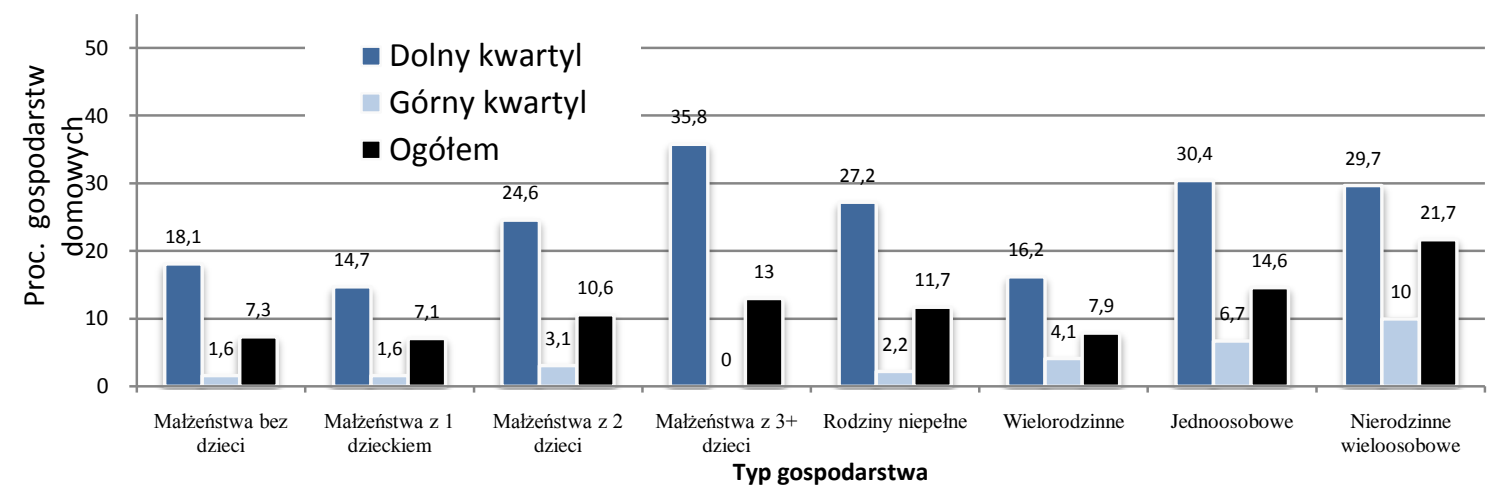

UWAGI: efekt główny typu gospodarstwa $F(7,11250)=16,587, p<0,000 ; \eta^{2}=0,010$, efekt główny dochodu $F(2,11250)=92,318, p<0,000, \eta^{2}=0,024$, efekt interakcji typu gospodarstwa i dochodu $\mathrm{F}(14,11250)=4,524, \mathrm{p}<0,000, \eta^{2}=0,008$

Wykres 4.1.18. Odsetek gospodarstw domowych korzystajacych z pomocy z zewnatrz ze względu na typ gospodarstwa $i$ wysokość dochodu na jednostkę ekwiwalentna (dolny i górny kwartyl)

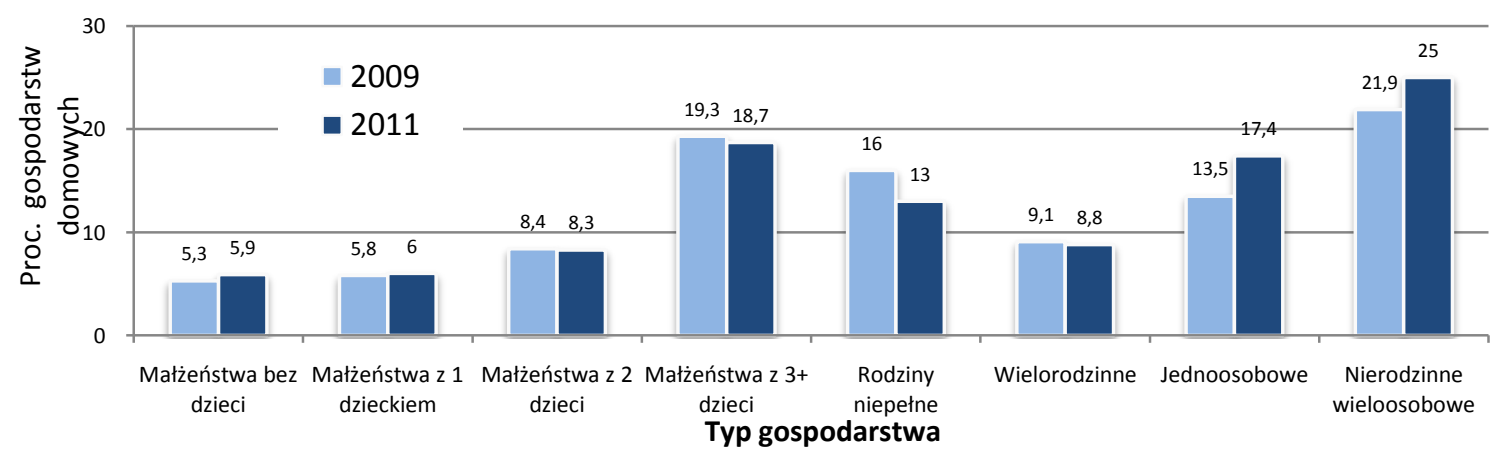

UWAGI: efekt główny typu gospodarstwa $F(7,8242)=41,394, p<0,000, \eta^{2}=0,034$, efekt główny roku badania $F(1,8242)<1$, ni, $\eta^{2}=0,000$, efekt interakcji typu gospodarstwa i roku badania $\mathrm{F}(7,8242)=4,348, \mathrm{p}<0,000, \eta^{2}=0,004$.

Wykres 4.1.19. Odsetek gospodarstw domowych korzystajacych z pomocy z zewnatrz w 2009 i 2011 r. ze względu na typ gospodarstwa w próbie panelowej 


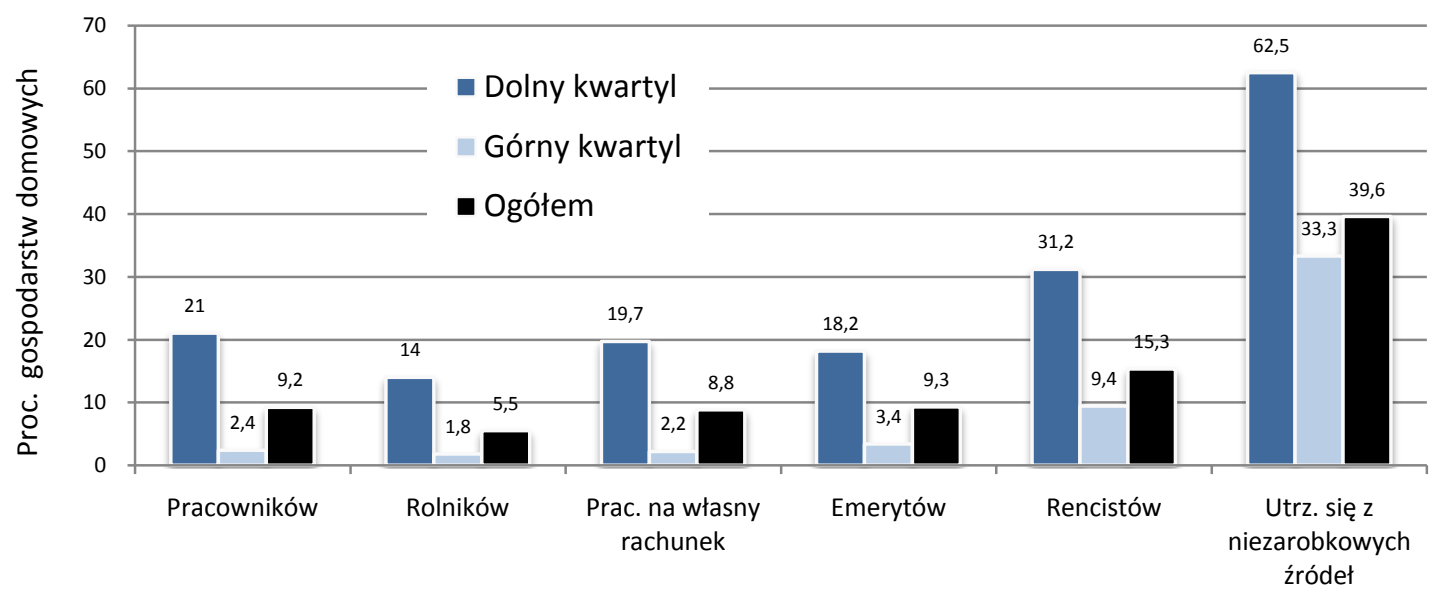

\section{Grupa społeczno-ekonomiczna}

UWAGI: efekt główny grupy $\mathrm{F}(5,11242)=52,186, \mathrm{p}<0,000 ; \eta^{2}=0,023$, efekt główny dochodu $\mathrm{F}(2,11242)=98,992, \mathrm{p}<0,000, \eta^{2}=0,026$, efekt interakcji grupy i dochodu $\mathrm{F}(10,11242)=5,794, \mathrm{p}<0,000, \eta^{2}=0,008$.

Wykres 4.1.20. Odsetek gospodarstw domowych korzystajacych z pomocy z zewnatrz ze względu na grupę społeczno-ekonomiczna gospodarstwa i wysokość dochodu na jednostkę ekwiwalentna (dolny i górny kwartyl)

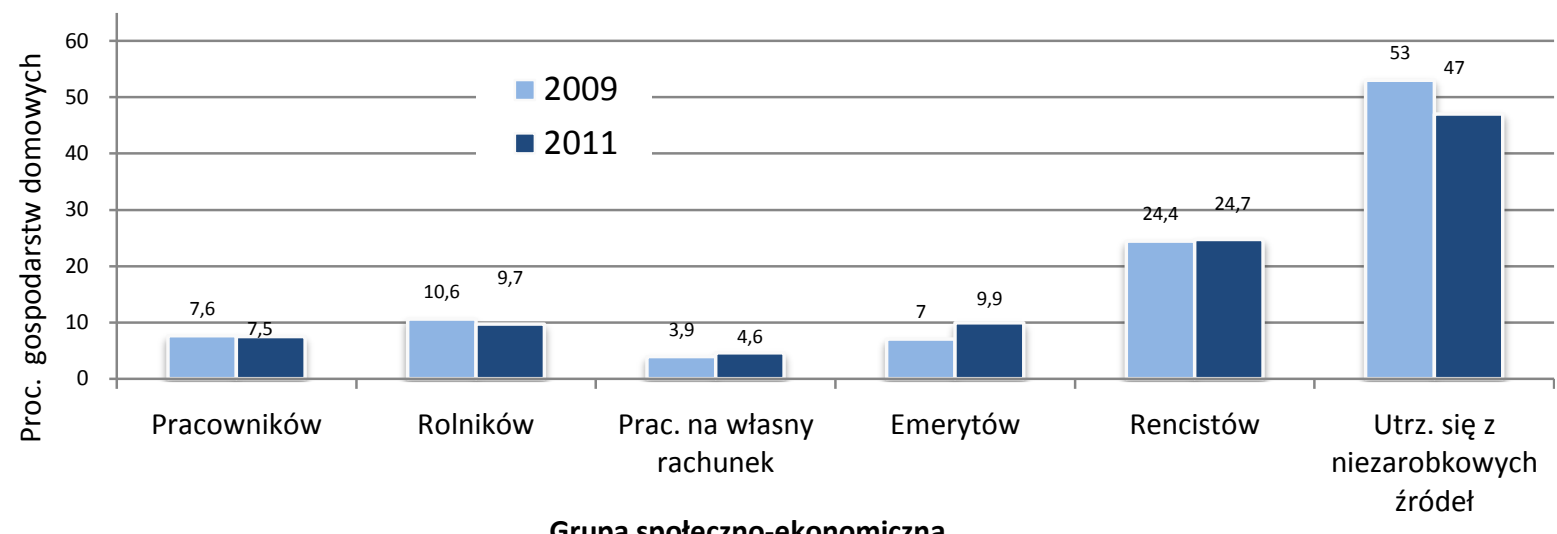

UWAGI: efekt główny grupy $\mathrm{F}(7,8239)=229,332, \mathrm{p}<0,000, \eta^{2}=0,122$, efekt główny roku badania $\mathrm{F}(1,8239)<1, \mathrm{ni}, \eta^{2}=0,000$, efekt interakcji grupy i roku badania $\mathrm{F}(5,8239)=5,309, \mathrm{p}<0,000, \eta^{2}=0,003$.

Wykres 4.1.21. Odsetek gospodarstw domowych korzystajacych z pomocy z zewnatrz w 2007 i 2009 r. ze względu na grupę spoleczno-ekonomiczna gospodarstwa w próbie panelowej

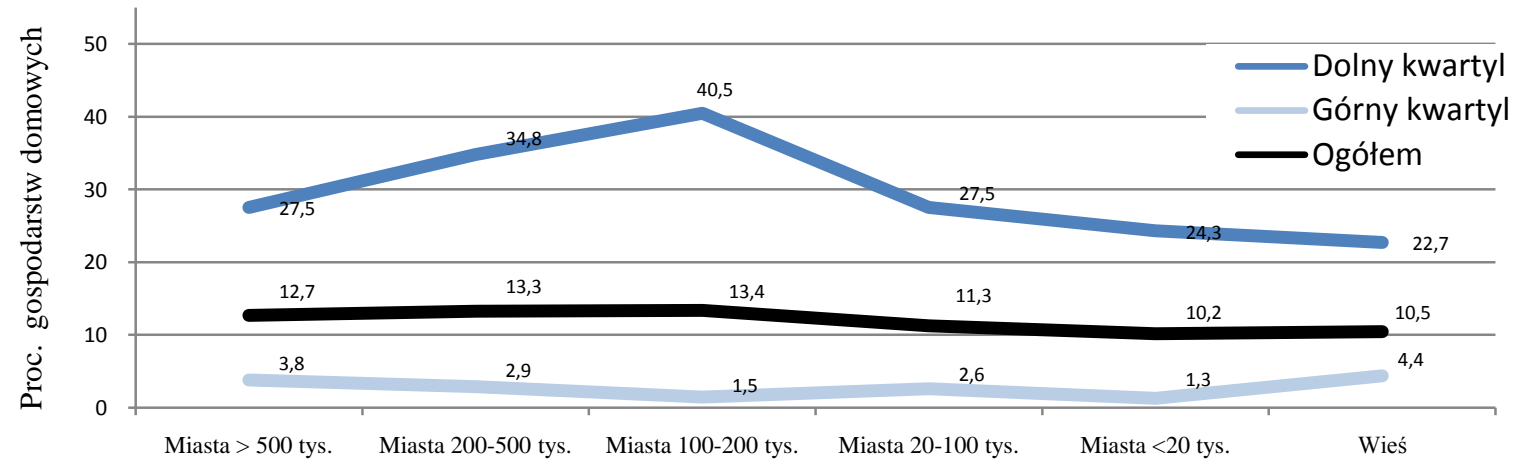

Klasa miejscowości zamieszkania

UWAGI: efekt główny klasy miejscowości $\mathrm{F}(5,11259)=4,415, \mathrm{p}<0,000 ; \eta^{2}=0,006$, efekt główny dochodu $\mathrm{F}(2,11259)=283,127, \mathrm{p}<0,000, \eta^{2}=0,070$, efekt interakcji klasy miejscowości i dochodu $\mathrm{F}(10,11259)=4,415, \mathrm{p}<0,000, \eta^{2}=0,006$.

Wykres 4.1.22. Odsetek gospodarstw domowych korzystajacych z pomocy z zewnatrz ze względu na klasę miejscowości zamieszkania i wysokość dochodu na jednostkę ekwiwalentna (dolny i górny kwartyl) 


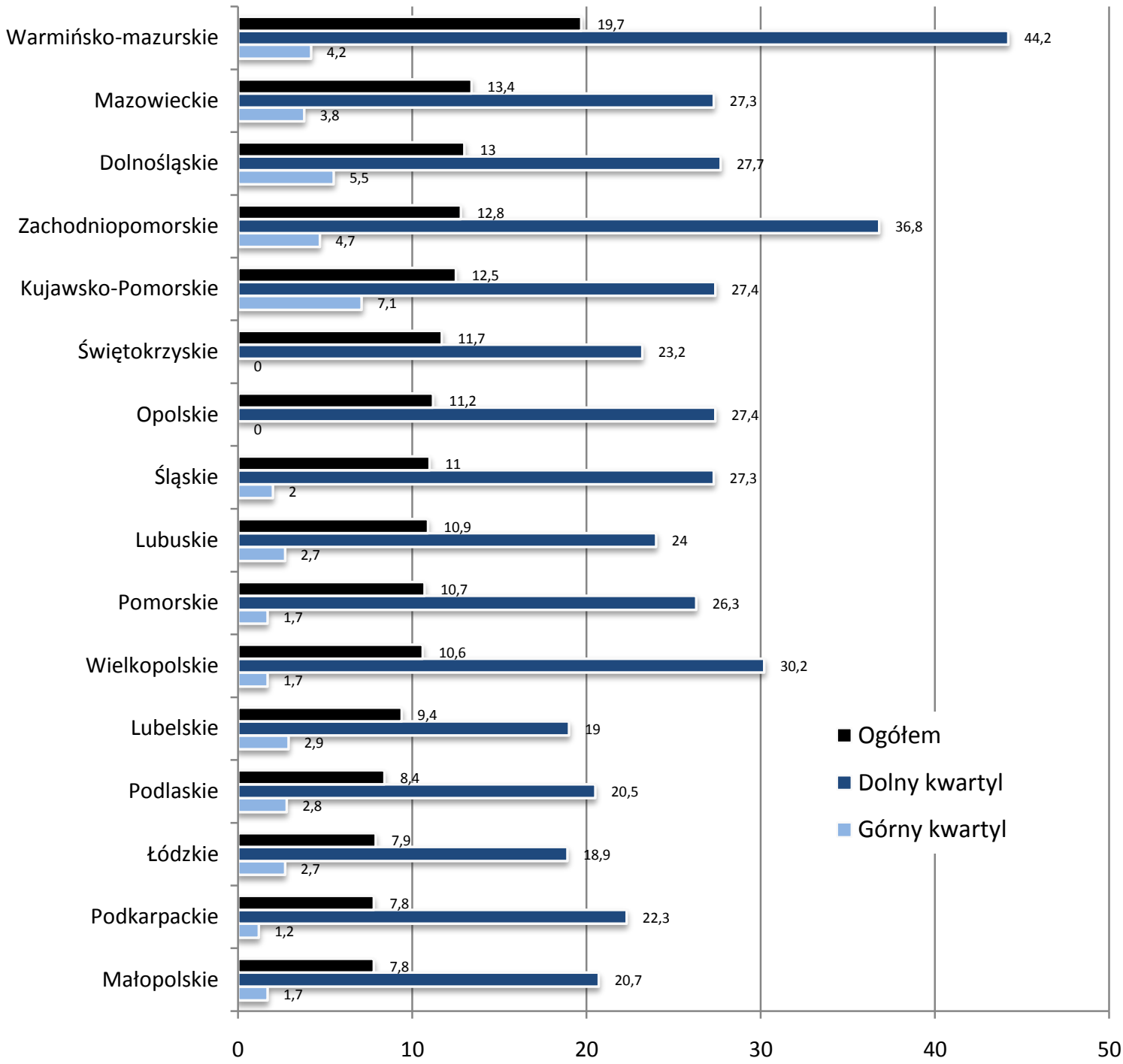

Proc.gospodarstw domowych

UWAGI: efekt główny województwa $\mathrm{F}(15,11247)=2,126, \mathrm{p}<0,005 ; \eta^{2}=0,003$, efekt główny dochodu $\mathrm{F}(2,11247)=400,856, \mathrm{p}<0,000$, $\eta^{2}=0,067$, efekt interakcji województwa i dochodu $\mathrm{F}(30,11247)=2,232, \mathrm{p}<0,000, \eta^{2}=0,006$.

Wykres 4.1.23. Procent gospodarstw domowych korzystajacych z pomocy z zewnatrz w przekroju wojewódzkim ogółem i ze względu na wysokość dochodu na jednostkę ekwiwalentna (dolny i górny kwartyl)

Najwyższy udział gospodarstw uzyskujących pomoc społeczną wystąpił w województwach warmińskomazurskim (20 proc.), mazowieckim, dolnośląskim, zachodniopomorskim i kujawsko-pomorskim (po ok. 13 proc.), najniższy zaś - w małopolskim, podkarpackim, łódzkim i podlaskim (po ok. 8 proc.) (wykres 4.1.23). Widać wyraźnie, że wcale nie w najbiedniejszych województwach (z wyjątkiem warmińsko-mazurskiego) zakres korzystania z zewnętrznej pomocy jest największy.

We wszystkich przekrojach z pomocy zewnętrznej korzystały głównie gospodarstwa domowe z dochodem poniżej pierwszego kwartyla, ale także pewien odsetek gospodarstw z dochodem powyżej trzeciego kwartyla. Najwięcej stosunkowo zamożnych gospodarstw korzystających z pomocy zewnętrznej było wśród nierodzinnych wieloosobowych (10 proc.) i jednoosobowych (6,7 proc.) (wykres 4.1.18), utrzymujących się z niezarobkowych źródeł (33 proc.) oraz rencistów (9,4 proc.) (wykres 4.1.19), woj. kujawsko-pomorskiego (7,1 proc.) (wykres 4.1.23). Świadczy to o niezbyt szczelnym systemie opieki społecznej i słabej kontroli odpowiednich służb nad transferami pieniędzy publicznych. 


\subsection{Wyżywienie}

\subsubsection{Sytuacja w 2011r. i jej zmiana w ostatnich czterech latach \\ Tomasz Panek}

Gospodarstwa domowe oceniały w marcu 2011 r., że najczęściej nie było ich finansowo stać w ciagu ostatniego roku na zaspokojenie potrzeb żywnościowych w zakresie ryb i przetworów rybnych (prawie 20 proc. gospodarstw), a następnie wyrobów cukierniczych oraz używek (odpowiednio około 16 proc. i ponad 15 proc. gospodarstw), mięsa i drobiu oraz owoców i przetworów owocowych (po odpowiednio około 13 i ponad 12 proc. gospodarstw).

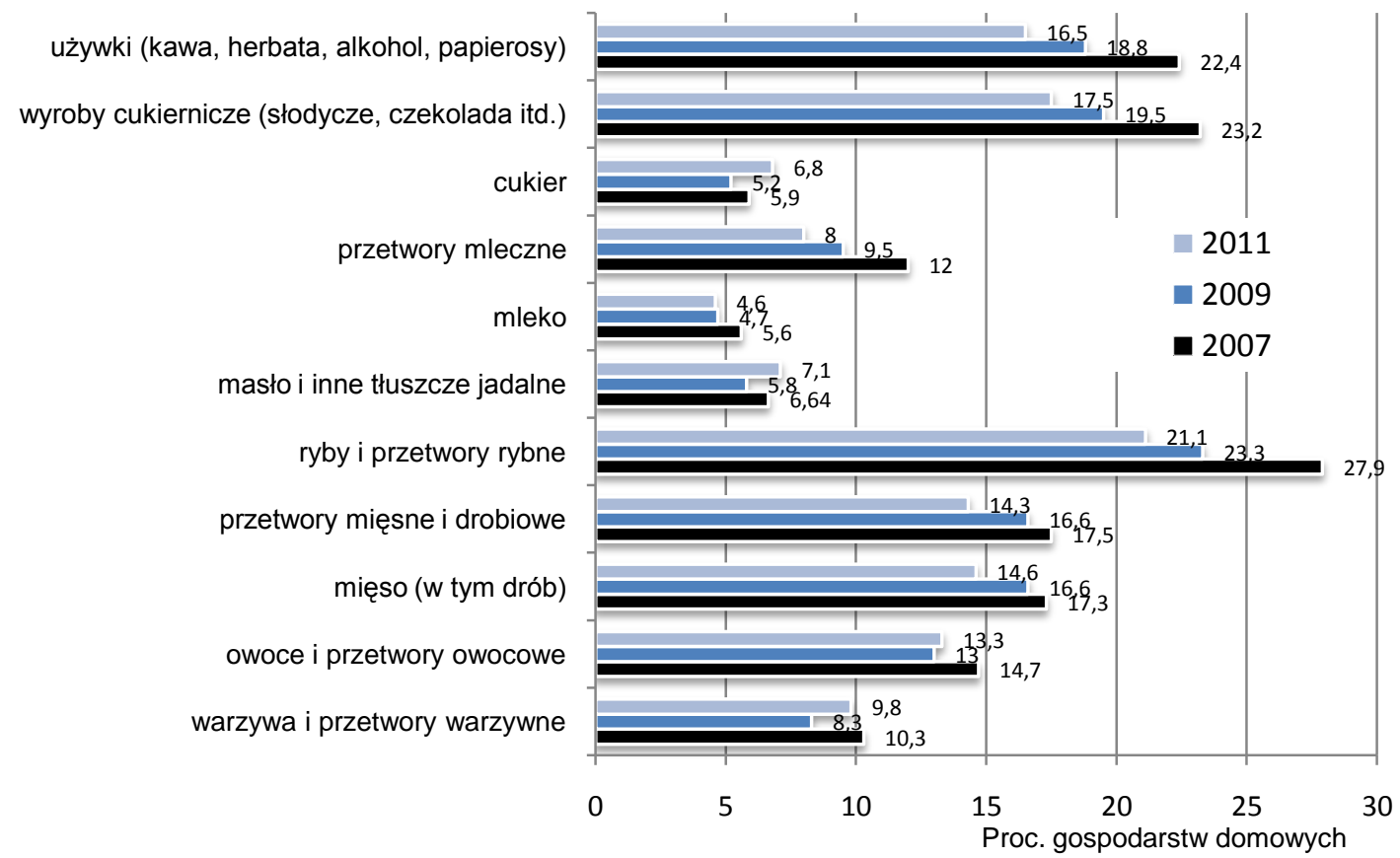

Wykres 4.2.1. Zakres niezaspokojenia potrzeb gospodarstw domowych na artykuły żywnościowe z powodów finansowych $w$ latach 2007-2011 w próbie panelowej.

W ostatnich czterech latach ${ }^{14}$ nastapiła poprawa stopnia zaspokojenia potrzeb gospodarstw domowych we wszystkich grupach artykułów żywnościowych z wyjątkiem cukru (wykres 4.2.1). Natomiast w latach 2009-2011 obserwujemy spadek trudności finansowych $\mathrm{w}$ zaspokojeniu potrzeb żywnościowych $\mathrm{z}$ wyjątkiem potrzeb $\mathrm{w}$ zakresie cukru oraz warzyw i przetworów warzywnych ${ }^{15}$ (wzrost odsetka gospodarstw mających takie trudności o odpowiednio ponad 1 i niecały 1 p.p.) (wykres 4.2.2). Zdecydowaną poprawę sytuacji w tym okresie obserwujemy przede wszystkim w przypadku wyrobów cukierniczych, używek oraz przetworów mięsnych i drobiowych (spadek odsetka gospodarstw domowych niemogących, ze względów finansowych zaspokoić potrzeb żywnościowych w tym zakresie po około 2 p.p). Znaczące pogorszenie się możliwości zaspokojenia potrzeb żywnościowych wystąpiło w latach 2009-2011 w zakresie prawie wszystkich artykułów żywnościowych (z wyjątkiem przetworów mlecznych i używek) tylko w grupie gospodarstw utrzymujących się z niezarobkowych źródeł.

Grupami gospodarstw, których najczęściej nie było stać gospodarstw na zakup grup artykułów żywnościowych w marcu 2011 r., były gospodarstwa utrzymujących się z niezarobkowych źródeł (odpowiednio dla kolejnych, wymienionych uprzednio grup artykułów żywnościowych około 47 proc., 43 proc., 36 proc., 38 proc. i 37 proc. gospodarstw) oraz gospodarstwa rencistów (odpowiednio około 39 proc., 31 proc., 34 proc., 29 proc. i 26 proc. gospodarstw). Wśród typów gospodarstw najczęściej wskazywały na brak środków finansowych na zakup wybranych grup artykułów żywnościowych gospodarstwa domowe nierodzinne jednoosobowe. Na trudności finansowe dotyczące zakupu artykułów żywnościowych, z których rezygnowano najczęściej, wskazywało w tej grupie odpowiednio około 24 proc., 25 proc., 22 proc., 21 proc. i 18 proc. gospodarstw. Kolejnym typem gospodarstw, których najczęściej nie stać było na zakup wskazanych grup artykułów żywnościowych, były gospodarstwa rodzin niepełnych (odpowiednio około 26 proc., 21 proc., 20 proc., 18 proc. i 17 proc.). W większości

\footnotetext{
${ }^{14}$ Zmiany w zakresie zaspokojenia potrzeb żywnościowych gospodarstw domowych w latach 2007-2011 dotyczą próby panelowej gospodarstw dla tych lat, czyli gospodarstw domowych, które zostały zbadane zarówno w 2007 r. jak i w 2009 r. i 2011 r.

15 Wszystkie zmiany w zakresie zaspokojenia potrzeb gospodarstw domowych na artykuły żywnościowe w latach 2009-2011 dotyczą próby panelowej gospodarstw dla tych lat, czyli tych gospodarstw domowych, które zostały zbadane z 2009 r. jak i w 2011 r.
} 
typów gospodarstw domowych generalnie nastąpiła poprawa możliwości finansowych zaspokojenia ich potrzeb w zakresie artykułów żywnościowych w minionych dwóch latach. Pogorszenie się sytuacji w tym zakresie obserwujemy w grupie gospodarstw wielorodzinnych i małżeństw niepełnych, przede wszystkim w zakresie warzyw i przetworów warzywnych, owoców i przetworów owocowych, masła i tłuszczy jadalnych, cukru oraz mleka i przetworów mlecznych.

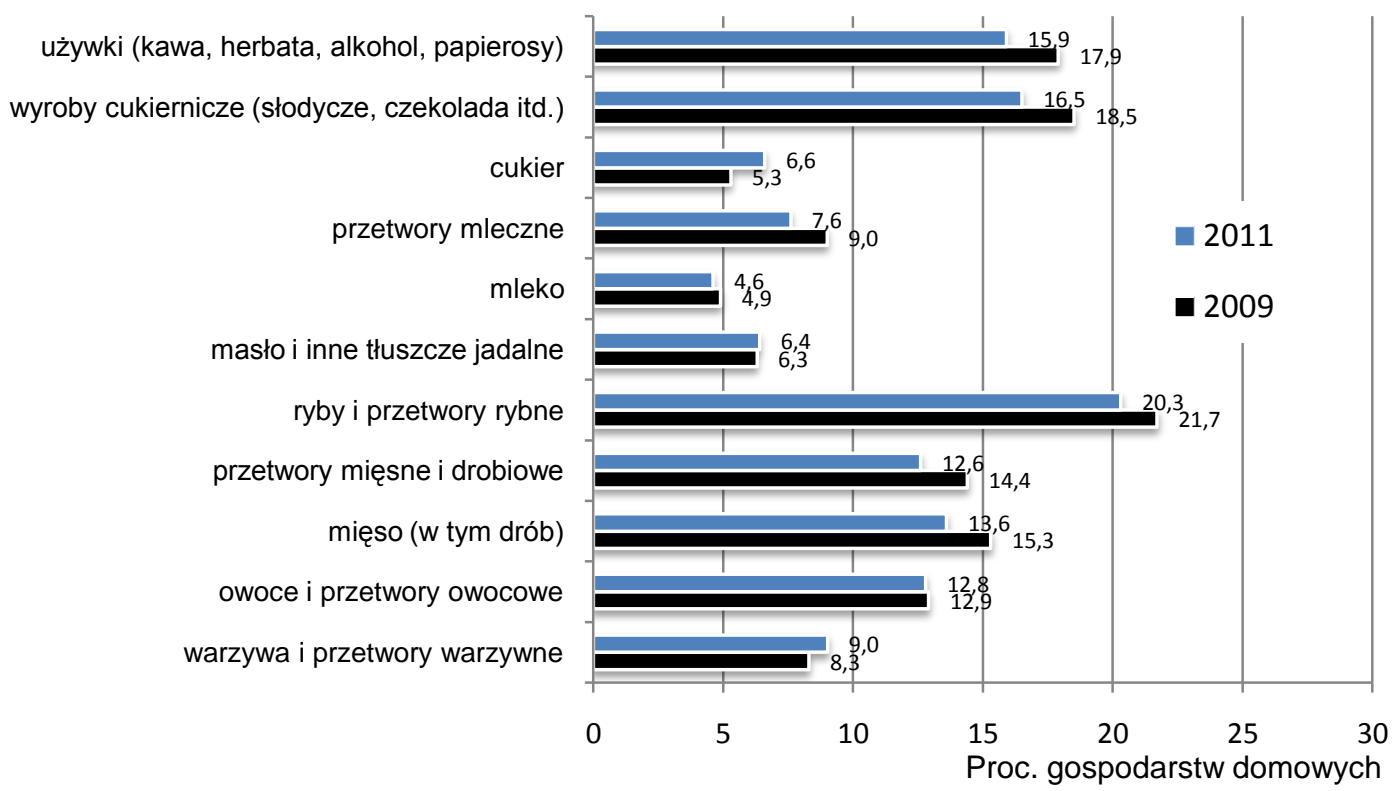

Wykres 4.2.2. Zakres niezaspokojenia potrzeb gospodarstw domowych na artykuły żywnościowe w 2009 i 2011 r. w próbie panelowej.

Procent gospodarstw domowych, których nie było stać ze względów finansowych na zakup artykułów żywnościowych, był dla każdej z analizowanych w badaniu grup artykułów znacząco wyższy w marcu $2011 \mathrm{r}$. w grupie gospodarstw z bezrobotnymi niż w grupie gospodarstw bez bezrobotnych,. Odpowiednio, dla kolejno wymienionych grup artykułów, z których rezygnowano najczęściej, konieczność rezygnacji zgłaszało w poniższych grupach gospodarstw prawie 31 proc. i prawie 18 proc., prawie 26 proc. i ponad 14 proc., prawie 25 proc. gospodarstw oraz prawie 14 proc., prawie 22 proc. i prawie 12 proc. oraz prawie 22 proc. i prawie 11 proc. gospodarstw. W obu grupach gospodarstw domowych i jednocześnie w prawie wszystkich grupach artykułów żywnościowych sytuacja ulegała w ciagu ostatnich 2 lat znaczącej poprawie.

Gospodarstwa domowe najczęściej zmuszane do rezygnacji w marcu 2011 r. ze względów finansowych z zakupu wybranych grup artykułów żywnościowych zamieszkiwały przede wszystkim na wsi (sytuacje takie deklarowało, odpowiednio dla kolejnych wymienionych uprzednio grup artykułów żywnościowych, około 24 proc., 18 proc., 17 proc., 16 proc. oraz ponad 14 proc. gospodarstw) oraz najmniejsze miasta, poniżej 20 tys. mieszkańców (odpowiednio około 20 proc., 17 proc., 16 proc. 13 proc. i 12 proc. gospodarstw). Najwyższy procent gospodarstw mających kłopoty finansowe $\mathrm{z}$ zaspokojeniem potrzeb w zakresie wybranych grup artykułów żywnościowych występował w badanym miesiącu w województwach łódzkim (odpowiednio około 27 proc., 24 proc., 22 proc., 17 proc. i 16 proc. gospodarstw) oraz podkarpackim (odpowiednio około 26 proc., 21 proc., 20 proc., 16 proc., i 14 proc. gospodarstw). W okresie marzec 2009-marzec 2011 znaczący wzrost odsetka gospodarstw domowych, których nie stać ze względów finansowych na zaspokojenie swoich potrzeb żywnościowych, nastąpił przede wszystkim w największych miastach o liczbie mieszkańców powyżej 500 tys. i to w większości grup artykułów żywnościowych, przy czym przede wszystkim w zakresie ryb i przetworów rybnych oraz cukru (o powyżej 3 p.p). W przekroju regionalnym tylko w kilku województwach i jedynie w zakresie nielicznych grup artykułów żywnościowych nastąpiło znaczące pogorszenie sytuacji w omawianym zakresie (o ponad 4 p.p). Dotyczyło to przede wszystkim województwa podlaskiego (znaczący wzrost odsetka gospodarstw, których nie stać ze względów finansowych na zaspokojenie potrzeb w zakresie owoców i przetworów owocowych, przetworów mlecznych i cukru), świętokrzyskiego (znaczący wzrost odsetka gospodarstw, których nie stać było na zaspokojenie potrzeb w zakresie owoców i przetworów owocowych oraz cukru) oraz województwa opolskiego (znaczący wzrost odsetka gospodarstw, których nie stać było na zaspokojenie potrzeb w zakresie warzyw i przetworów warzywnych, owoców i przetworów owocowych oraz ryb i przetworów rybnych).

Około 62 proc. gospodarstw uważało w marcu 2011 r., że zaspokojenie ich potrzeb żywnościowych w porównaniu do sytuacji sprzed 2 lat nie zmieniło się, około 31 proc. odczuło pogorszenie, a około 7 proc. poprawę. W stosunku do ocen formułowanych w marcu 2009 r. nastąpił spadek zarówno ocen negatywnych (o 3 p.p) jak i ocen pozytywnych (o prawie 5 p.p). 
Najczęściej zmiany na gorsze deklarowały gospodarstwa domowe utrzymujących się z niezarobkowych źródeł (ponad 49 proc. gospodarstw) oraz gospodarstwa domowe rencistów (prawie 48 proc. gospodarstw). Wśród typów gospodarstw pogorszenie się sytuacji w zakresie wyżywienia odczuwały przede wszystkim gospodarstwa rodzin niepełnych (prawie 38 proc. gospodarstw) oraz gospodarstwa małżeństw wielodzietnych i nierodzinne jednoosobowe (po prawie 36 proc. i ponad 35 proc. gospodarstw $\mathrm{z}$ tych grup).

Negatywne oceny zmian w zaspokojeniu potrzeb żywnościowych były zdecydowanie częściej formułowane w grupie gospodarstw z bezrobotnymi, niż w grupie gospodarstw domowych bez bezrobotnych (odpowiednio ponad 45 proc. i prawie 30 proc. gospodarstw $z$ tych grup).

Zróżnicowanie gospodarstw domowych deklarujących pogorszenie się stopnia zaspokojenia ich potrzeb żywnościowych w przekroju klasy miejscowości zamieszkania było nieznaczne. Najczęściej gospodarstwa te występowały w grupie gospodarstw zamieszkujących wieś (około 33 proc. gospodarstw wiejskich). Województwami, w których gospodarstwa domowe najczęściej uważały, że poziom zaspokojenia ich potrzeb żywnościowych pogorszył się w porównaniu do sytuacji sprzed dwóch lat były województwa opolskie i lubelskie (odpowiednio prawie 39 proc. i ponad 35 proc. gospodarstw).

\subsubsection{Zmiana w zaspokojeniu potrzeb żywnościowych w latach 2000-2011}

\section{Janusz Czapiński}

W okresie minionych 10 lat spadł odsetek gospodarstw, których nie stać ze względów finansowych na zakup artykułów żywnościowych w zakresie wszystkich grup (wykres 4.2.3). Największy spadek dotyczy używek (3,5krotny), wyrobów cukierniczych (prawie 3-krotny), owoców i przetworów owocowych (ponad 2,5-krotny), mięsa i drobiu oraz przetworów mięsnych i drobiowych (2,5-krotny), ryb i przetworów rybnych (2-krotny) -- a więc tych artykułów, na które w poprzednich latach najczęściej nie było stać gospodarstw domowych.

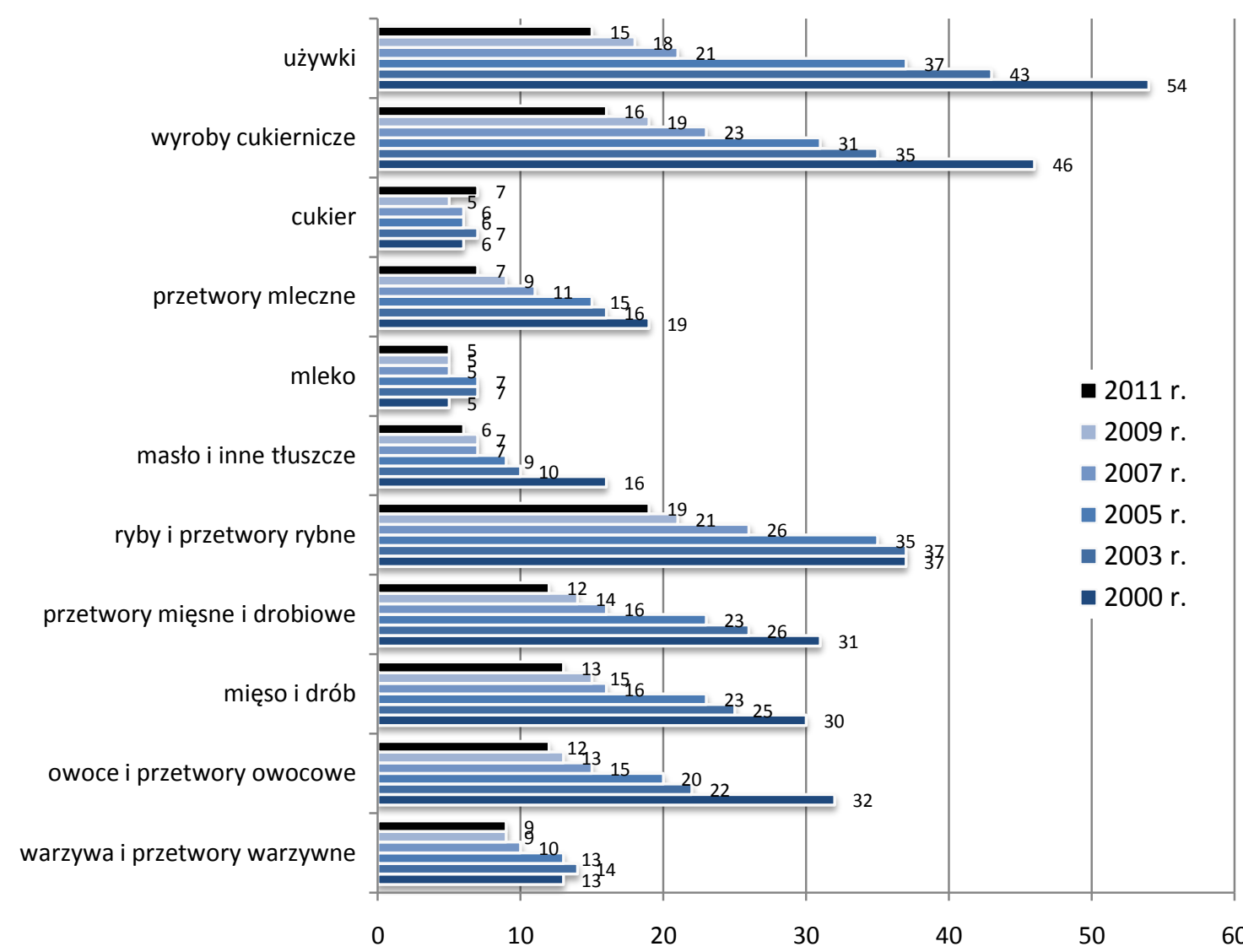

Proc. gospodarstw domowych

Wykres 4.2.3. Procent gospodarstw domowych, których nie stać na zakup wystarczajacych ilości różnych artykułów żywnościowych $w$ latach 2000-2011 $\mathrm{r}$.

Nastąpiła też pewna zmiana w porządku powszechności rezygnowania z zakupów z powodów finansowych z różnych grup artykułów żywnościowych: używki z pierwszego miejsca spadły na drugie (po rybach i przetworach rybnych), owoce i przetworzy owocowe spadły z czwartego na piąte miejsce. W ostatnim roku wzrosła liczba rezygnacji jedynie z zakupu cukru, ale już nie z wyrobów cukierniczych, natomiast znacząco spadła liczba rezygnacji z zakupu większości grup artykułów, najbardziej używek (o 3 p.p.). 


\subsection{Zasobność materialna}

\subsubsection{Sytuacja w 2011 r. i jej zmiana w ostatnich czterech latach \\ Tomasz Panek}

Jeden z podstawowych elementów zasobności gospodarstw domowych stanowi posiadanie przez nie dóbr trwałego użytku. Spośród wyszczególnionych w badaniu dóbr najbardziej powszechnymi były w marcu 2011 r. pralka automatyczna i płatna telewizja satelitarna lub kablowa. Pralki automatycznej nie posiadało ok. 9 proc. badanych gospodarstw, a płatnej telewizji satelitarnej lub kablowej niecałe 30 proc. Do dóbr trwałego użytku, które gospodarstwa posiadały najrzadziej, należały łódź motorowa (niecałe 1 proc.), dom letniskowy (niecałe 5 proc.), działka rekreacyjna (niecałe 12 proc.) oraz kino domowe (niecałe 18 proc.). W okresie marzec 2007-marzec 2011 wyposażenie gospodarstw domowych w większość uwzględnionych w badaniu dóbr trwałego użytku znacznie wzrosło (wykres 4.3.1) ${ }^{16}$.

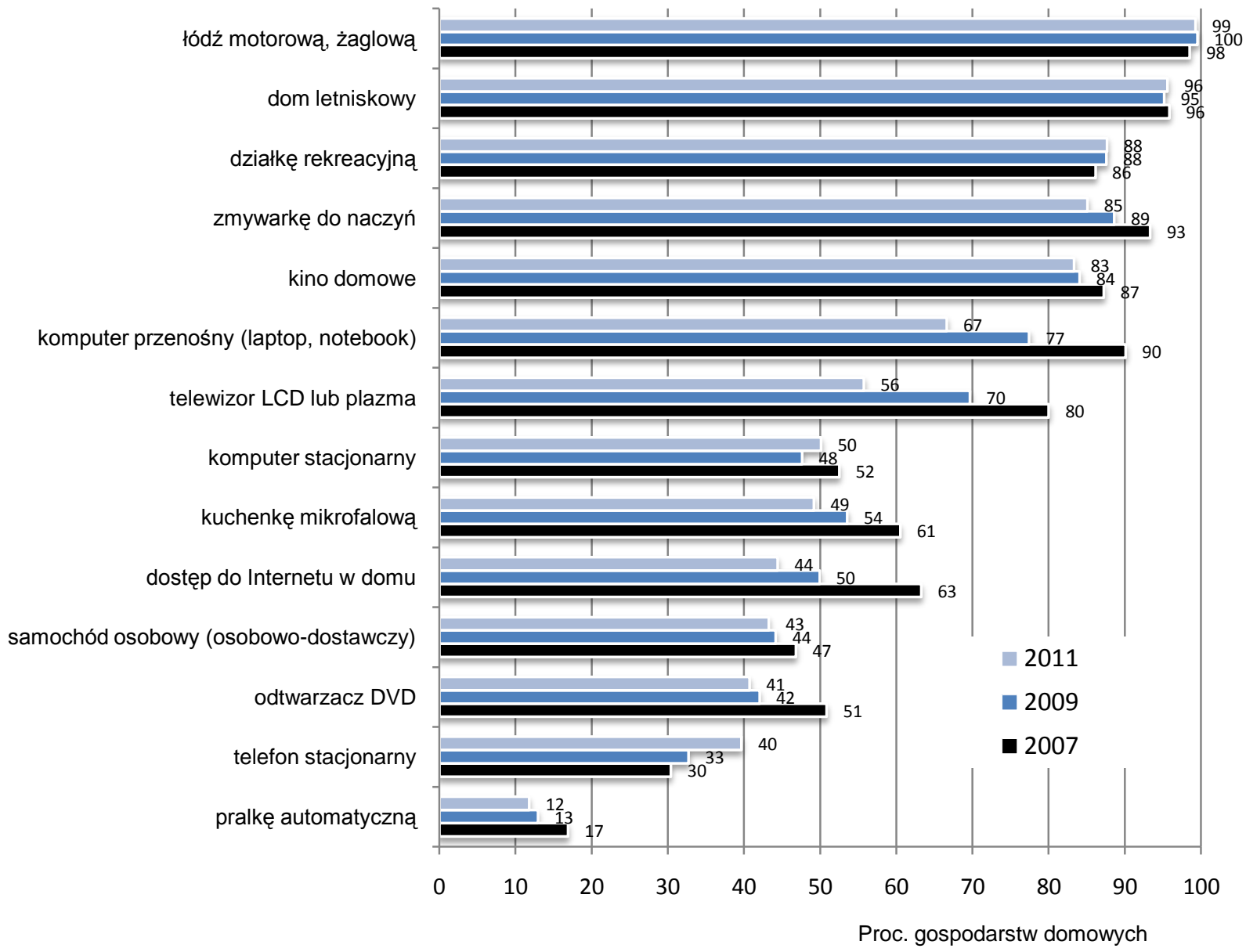

Wykres 4.3.1. Procent gospodarstw domowych nieposiadajacych wybranych dóbr trwałego użytku w 2007, $2009 i$

2011 r. w próbie panelowej.

$\mathrm{W}$ ostatnich dwóch latach ${ }^{17}$ także nastąpił znaczący wzrost wyposażenia gospodarstw domowych w dobra trwałego użytku z wyjątkiem telefonu domowego (stacjonarnego) i komputera stacjonarnego, co jest związane $\mathrm{z}$ zastępowaniem ich przez telefon mobilny i komputer przenośny (wykres 4.3.1). Największy wzrost odsetka gospodarstw domowych w zakresie ich wyposażenia w dobra trwałego użytku w tym okresie dotyczy telewizora LCD lub plazmy oraz komputera przenośnego (odpowiednio o prawie 14 i prawie 11 p.p. wzrost odsetka gospodarstw domowych posiadających te dobra).

\footnotetext{
${ }^{16}$ Wszystkie zmiany w zakresie zasobności materialnej w latach 2007-2011 dotyczą próby panelowej z tych lat, czyli tych gospodarstw domowych, które zostały zbadane w 2007 r. jak i w 2009 r. i 2011 r.

${ }^{17}$ Zmiany w zakresie zasobności materialnej w latach 2009-2011 dotyczą próby panelowej z tych lat czyli gospodarstw domowych, które zostały zbadane w 2009 r. i w 2011 r.
} 
Do przeciętnie najsłabiej wyposażonych w dobra trwałego użytku gospodarstw domowych należały w marcu 2011 r. gospodarstwa utrzymujących się z niezarobkowych źródeł innych niż emerytura i renta oraz rencistów. Gospodarstwami takimi, rozpatrując typ gospodarstwa, były najczęściej gospodarstwa nierodzinne (zarówno jednoosobowe jak i wieloosobowe) oraz gospodarstwa rodzin niepełnych. Stopień wyposażenia w dobra trwałego użytku gospodarstw domowych bez bezrobotnych jest nieznacznie wyższy, dla zdecydowanej większości tych dóbr, niż gospodarstw domowych $\mathrm{z}$ bezrobotnymi. Natomiast stopień wyposażenia w dobra trwałego użytku grup gospodarstw wyodrębnionych ze względu na klasę miejscowości zamieszkania oraz województw jest zróżnicowany w zależności od wyróżnionych w badaniu dób, chociaż w przypadku większości dóbr najsłabiej wyposażone są w te dobra gospodarstwa domowe wiejskie.

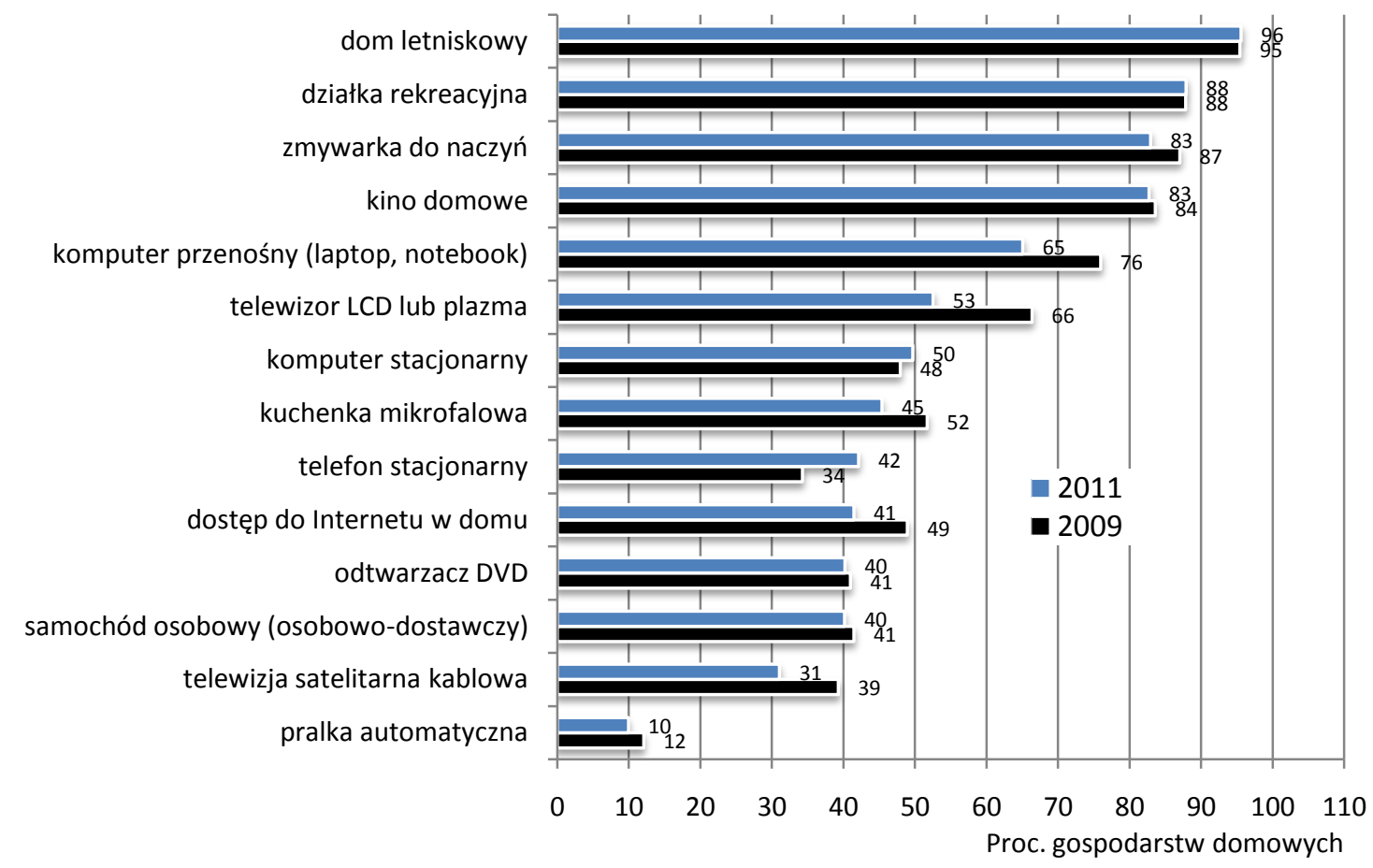

Wykres 4.3.2. Procent gospodarstw domowych nieposiadajacych wybranych dóbr trwałego użytku w $2009 i 2011$ r. w próbie panelowej

Brak niektórych dóbr trwałego użytku nie wynika często $\mathrm{z}$ braku możliwości finansowych ich zakupu, lecz z braku chęci ich posiadania. Dobrami najczęściej nieposiadanymi przez gospodarstwa domowe, gdyż na ich zakup nie mogły one sobie pozwolić, były w marcu 2011 r. przede wszystkim domek letniskowy i działka rekreacyjna (odpowiednio 40 proc. i ponad 30 proc. gospodarstw domowych, które nie mają tych dóbr). W ostatnich czterech latach obserwujemy silny spadek odsetka gospodarstw domowych, wśród gospodarstw nieposiadających tych dóbr, które nie mogą sobie pozwolić ze względów finansowych na ich zakup w przypadku wszystkich uwzględnionych w badaniu dóbr, przy tym największy w przypadku samochodu osobowego i komputera stacjonarnego (po ponad 16 p.p, wykres 4.3.2). W latach 2009-2011 jedynie w przypadku telewizora LCD lub plazmy oraz odtwarzacza DVD wzrósł znacząco odsetek gospodarstw domowych, wśród gospodarstw domowych nieposiadających dóbr, które nie mogły pozwolić sobie na ich zakup ze względów finansowych (wykres 4.3.4). Wzrost ten wynika jednakże tylko ze zwiększenia w tym okresie odsetka gospodarstw domowych, które chciałyby posiadać to dobro, gdyż odsetek gospodarstw domowych nieposiadających dóbr trwałego użytku ze względów finansowych w całej badanej populacji (a nie tylko w populacji gospodarstw nieposiadających tych dóbr) zmniejszył się w ostatnich dwóch latach w przypadku każdego z rozważanych dóbr.

Różnice pomiędzy grupami gospodarstw domowych, wyróżnionymi ze względu na przyjęte w badaniu kryteria, w zakresie nieposiadania ze względów finansowych dóbr trwałego użytku w marcu 2011 r. są różnokierunkowe. Największe różnice w tym zakresie obserwujemy pomiędzy grupą gospodarstw bez bezrobotnych i grupa gospodarstw z bezrobotnymi. Odsetki gospodarstw z bezrobotnymi, które ze względów finansowych nie mogą sobie pozwolić na posiadanie pewnych dóbr, są znacząco wyższe niż w przypadku grupy gospodarstw bez bezrobotnych, szczególnie w przypadku kina domowego (odpowiednio prawie 46 proc. i ponad 27 proc. gospodarstw w tych grupach nie mogły sobie pozwolić na jego zakup), komputera przenośnego (odpowiednio ponad 37 proc. i ponad 20 proc. gospodarstw w tych grupach go nie posiadało ze względów finansowych) oraz zmywarki do naczyń (odpowiednio ponad 42 i ponad 26 proc. gospodarstw było niewyposażonych w zmywarkę do naczyń w tych grupach ze względów finansowych). Ponadto, na finansowe przyczyny nieposiadania dóbr trwałego użytku 
stosunkowo najczęściej wskazywały gospodarstwa domowe rencistów i utrzymujących się z niezarobkowych źródeł oraz gospodarstwa domowe małżeństw wielodzietnych i rodzin niepełnych oraz wielorodzinne.

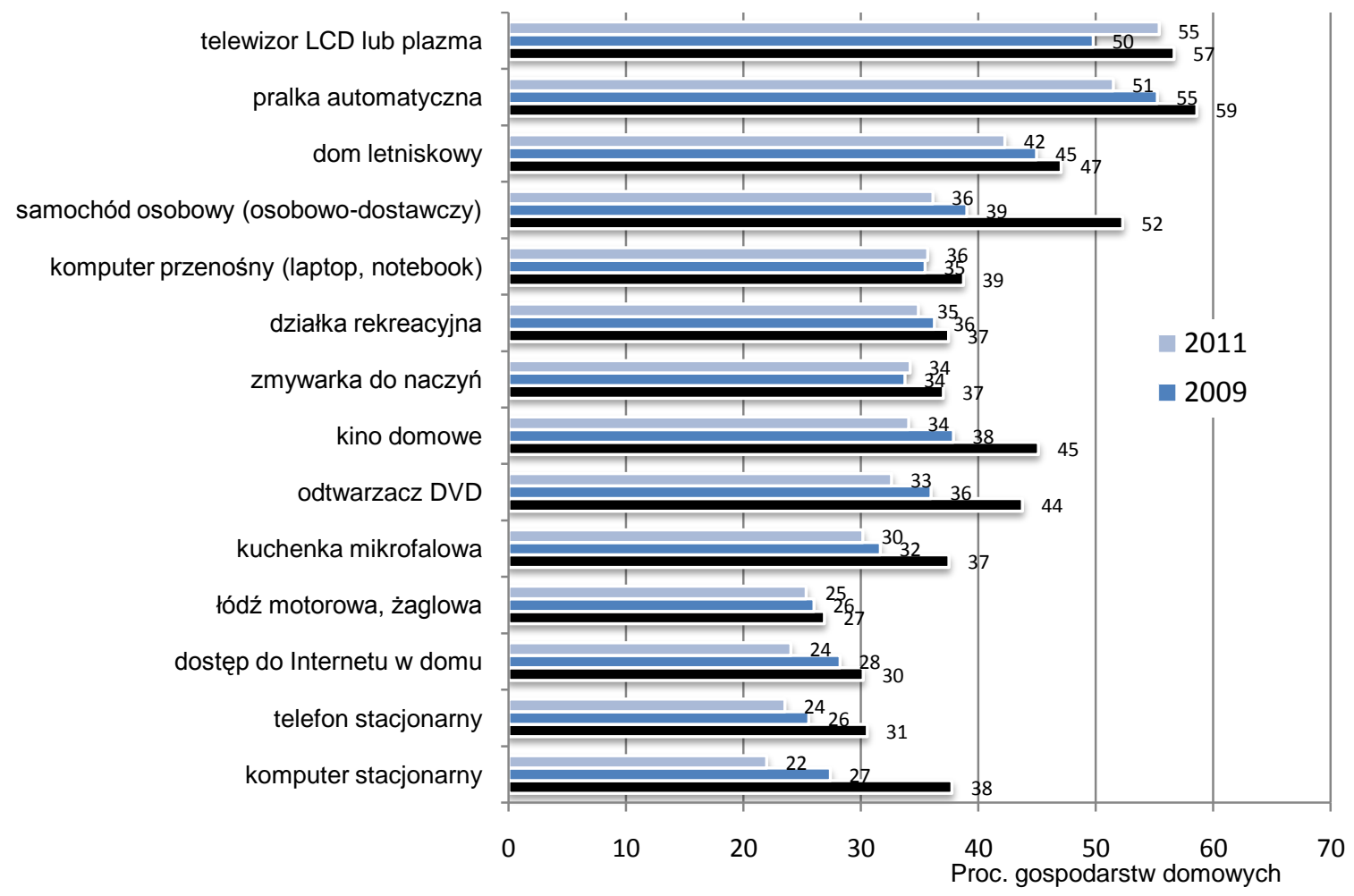

Wykres 4.3.3. Procent gospodarstw, w których brak dóbr wynika z braku środków finansowych na ich zakup w latach 2007-2011 w próbie panelowej

W marcu 2011 r. 62 proc. gospodarstw nie posiadało oszczędności. Wśród gospodarstw domowych deklarujących posiadanie oszczędności wyraźnie dominują gospodarstwa o oszczędnościach stanowiących równoważność ich od 1-miesięcznych do 3-miesięcznych dochodów (ponad 33 proc. gospodarstw). W okresie marzec 2007-marzec 2011 nastąpił znaczący wzrost odsetka gospodarstw domowych posiadających oszczędności (o ponad 9 p.p, wykres 4.3.4). W ostatnich dwóch latach także obserwujemy wzrost odsetka gospodarstw domowych posiadających oszczędności (o przeszło 4 p.p, wykres 4.3.5).

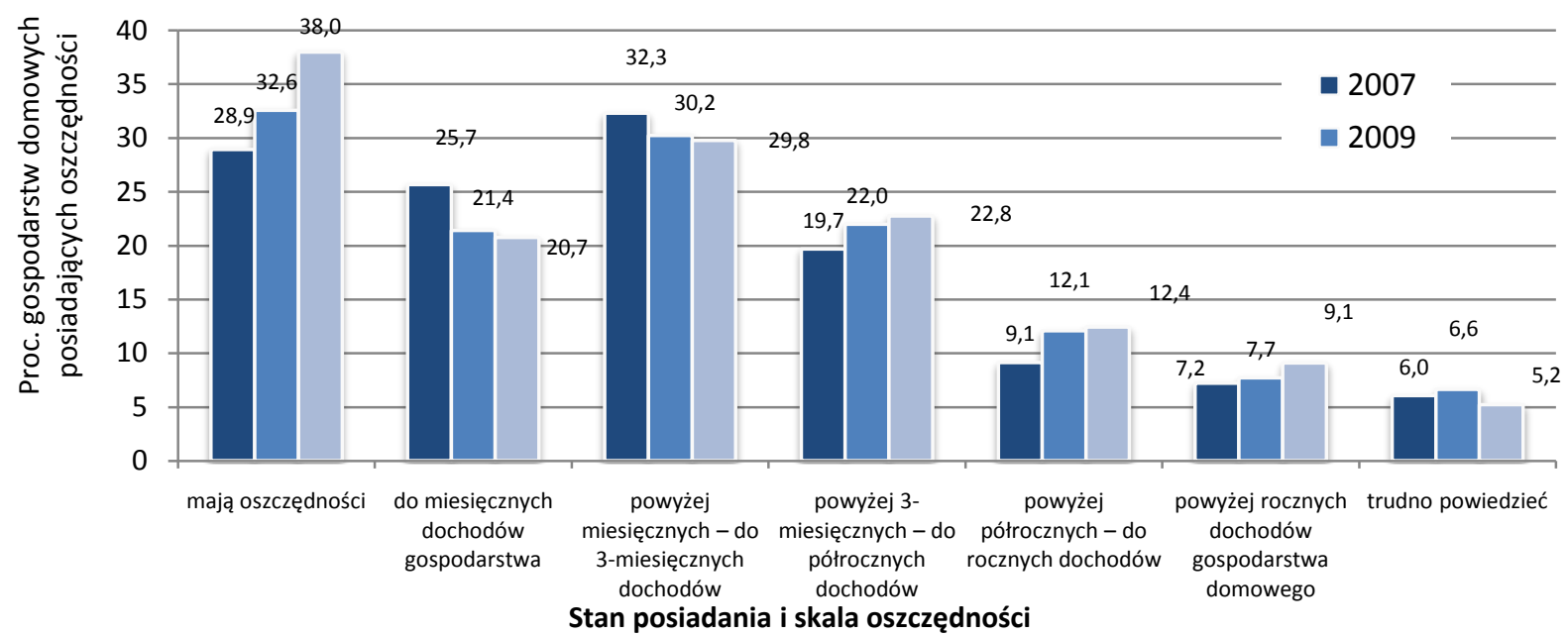

Wykres 4.3.4. Stan posiadania i skala oszczędności wśród gospodarstw domowych posiadajacych oszczędności w latach 2007-2011 w próbie panelowej. 


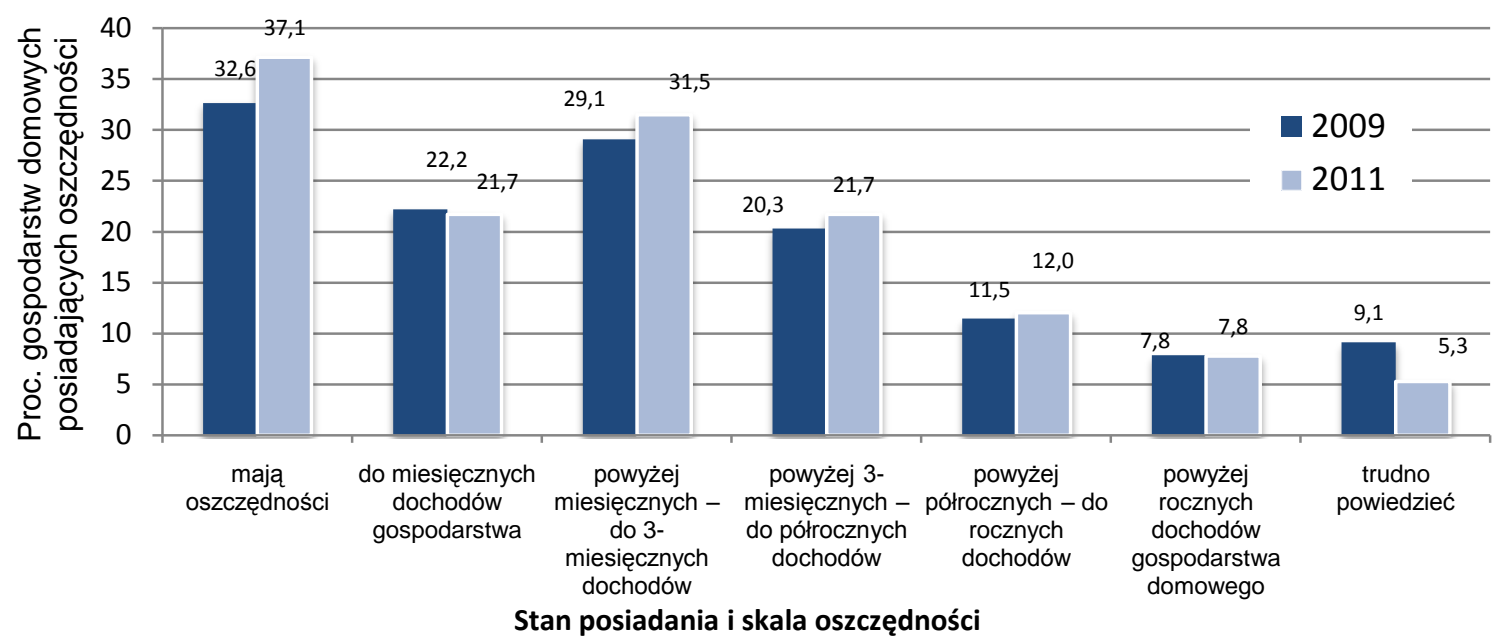

Wykres 4.3.5. Stan posiadania i skala oszczędności gospodarstw domowych $w$ latach $w 2009$ i 2011 r. w próbie panelowej.

Zdecydowanie najrzadziej deklarują posiadanie oszczędności gospodarstwa utrzymujących się $\mathrm{Z}$ niezarobkowych źródeł (prawie 82 proc.) oraz gospodarstwa rencistów (ponad 81 proc.). Najczęściej gospodarstwa domowe nieposiadające oszczędności występują wśród gospodarstw domowych małżeństw wielodzietnych i rodzin niepełnych (około 73 proc. i około 71 proc.). Procent gospodarstw domowych bez bezrobotnych nieposiadających oszczędności jest znacząco niższy niż w grupie gospodarstw z bezrobotnymi (odpowiednio prawie 61 proc. i prawie 75 proc. gospodarstw). We wszystkich grupach społeczno-ekonomicznych i typach gospodarstw domowych nastąpił znaczący wzrost oszczędności w ciągu ostatnich 2 lat, poza gospodarstwami domowymi pracującymi na własny rachunek, w której to grupie odsetek gospodarstw posiadających oszczędności nie uległ zasadniczym zmianom.

Im mniejsza miejscowość zamieszkania tym większy procent gospodarstw nie posiada oszczędności. Gospodarstwa domowe deklarujące nieposiadanie oszczędności najczęściej mieszkają na wsi oraz w najmniejszych miastach (odpowiednio prawie 71 proc. oraz ponad 67 proc. gospodarstw z tych miejscowości zamieszkania). Zróżnicowanie międzywojewódzkie gospodarstw domowych nie posiadających oszczędności nie jest zbyt duże. Województwami, w których gospodarstwa najczęściej nie posiadają oszczędności, są warmińsko-mazurskie (ponad 76 proc. gospodarstw) oraz lubelskie (ponad 66 proc. gospodarstw). W marcu 2011 r. w stosunku do marca 2009 r. nastąpił wzrost odsetka gospodarstw domowych dysponujących oszczędnościami we wszystkich klasach miejscowości zamieszkania oraz województwach, przy czym największy w województwie opolskim (nastąpił w nim wzrost odsetka gospodarstw domowych posiadających oszczędności prawie 12 p.p).

Ponad 68 proc. gospodarstw posiadających w marcu 2011 r. oszczędności miało je w formie lokat w bankach w złotych, a prawie 42 proc. w gotówce (wykres 4.3.6). Najczęściej w bankach w złotych lokowały swoje oszczędności gospodarstwa domowe rolników (prawie 71 proc.), a oszczędności w formie gotówkowej relatywnie najczęściej posiadały także gospodarstwa domowe rolników (ponad 54 proc.) oraz gospodarstwa domowe utrzymujących się z niezarobkowych źródeł (także ponad 54 proc.). Spośród typów gospodarstw swoje oszczędności lokowały w bankach w złotych przede wszystkim małżeństwa z 1 dzieckiem (prawie 71 proc.). Gotówka była natomiast relatywnie najczęstszą formą oszczędności w gospodarstwach wielorodzinnych (ponad 54 proc.). Zarówno w grupie gospodarstw bez bezrobotnych jak i w grupie gospodarstw z bezrobotnymi zdecydowanie najczęstszą formą oszczędności były lokaty w bankach w złotych (odpowiednio ponad 68 proc. i ponad 63 proc. gospodarstw z tych grup) oraz w gotówce (odpowiednio w prawie 42 proc. i w prawie 44 proc. gospodarstw).

Relatywnie największy odsetek gospodarstw lokował swoje oszczędności w bankach w złotych w największych miastach liczących powyżej 500 tys. mieszkańców (ponad 73 proc.). Lokowanie oszczędności w gotówce preferowały najczęściej gospodarstwa zamieszkujące na wsi i w najmniejszych miastach (odpowiednio prawie 53 proc. i prawie 49 proc.). Lokaty oszczędności w bankach w złotych najczęściej posiadały przede wszystkim gospodarstwa zamieszkujące w województwach zachodnio-pomorskim i podlaskim (po ponad 74 proc.). Najwyższe odsetki gospodarstw mających oszczędności w gotówce zamieszkiwały województwa warmińsko-mazurskie (prawie 53 proc.) oraz lubelskie (ponad 50 proc. gospodarstw). 


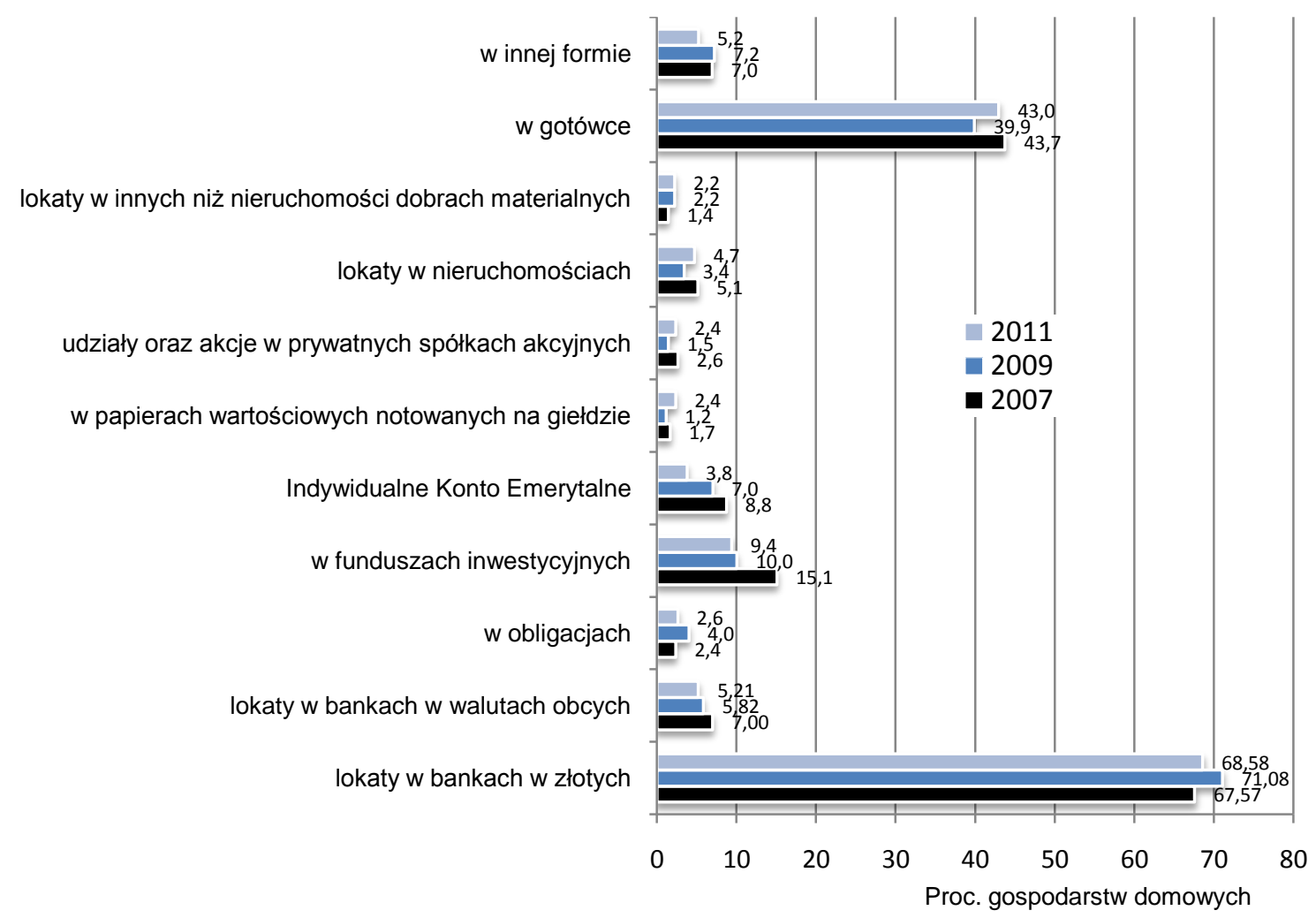

Wykres 4.3.6. Formy oszczędności gospodarstw domowych, które posiadaja oszczędności, w latach 2007-2011 w próbie panelowej.

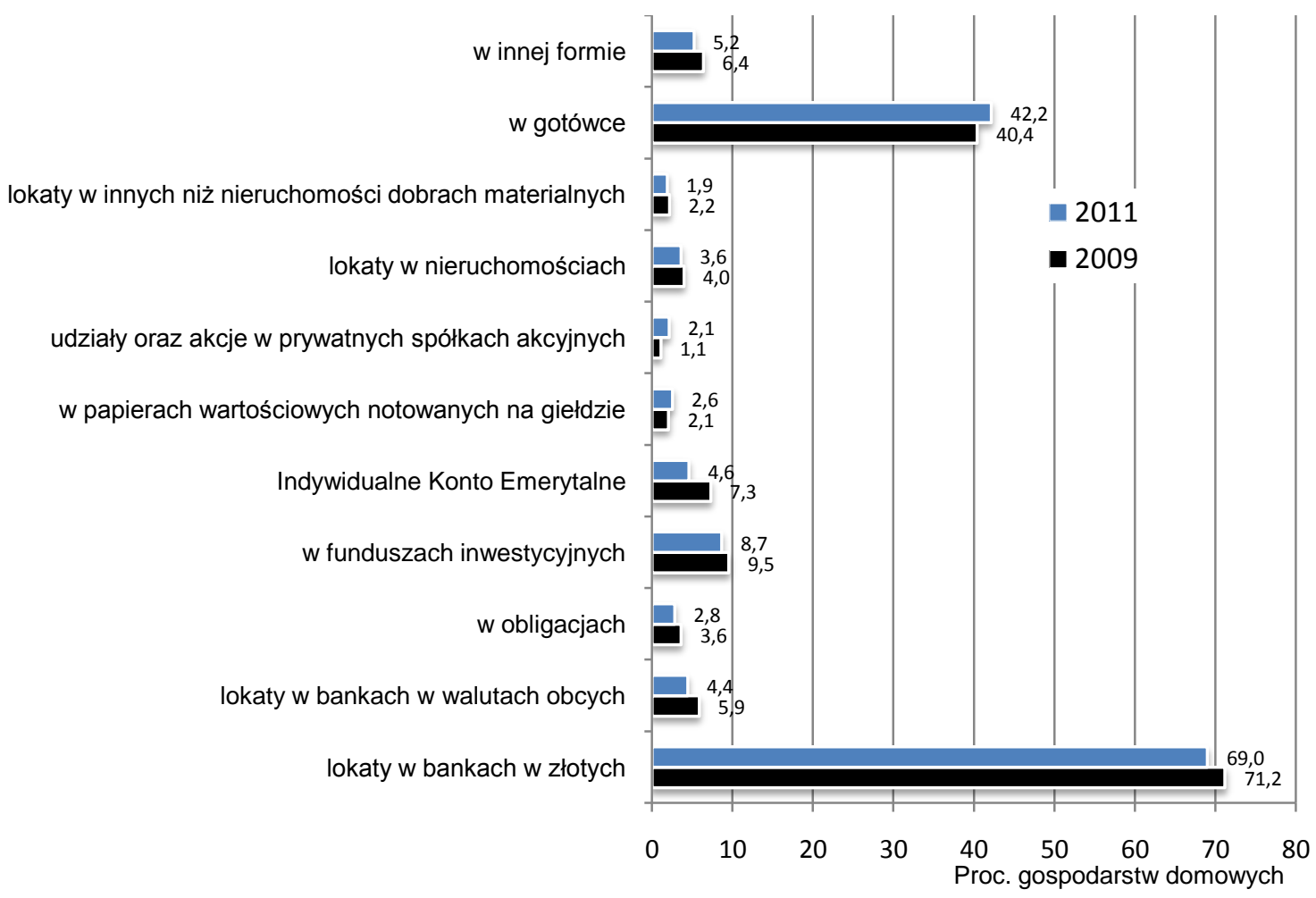

Wykres 4.3.7. Formy oszczędności gospodarstw domowych, które posiadaja oszczędności, w 2009 i 2011 r. w próbie panelowej.

W latach 2007-2011 nastąpił nieznaczny wzrost odsetka gospodarstw posiadających oszczędności tylko w postaci lokat w bankach w złotych (o 1 p.p., wykres 4.3.6). W ostatnich dwóch latach odsetek gospodarstw posiadających oszczędności wzrósł wyłącznie w grupach gospodarstw mających oszczędności w gotówce oraz w postaci udziałów oraz akcji w prywatnych spółkach akcyjnych (wykres 4.3.7). Relatywnie największy wzrost 
odsetka takich gospodarstw domowych obserwujemy w ostatnich dwóch latach w grupach gospodarstw emerytów, rencistów i utrzymujących się z niezarobkowych źródeł w przypadku gotówki (o około 7 p.p) i utrzymujących się z niezarobkowych źródeł w przypadku udziałów i akcji (o prawie 4 p.p) oraz gospodarstw rodzin niepełnych i małżeństw wielodzietnych w przypadku gotówki (odpowiednio o ponad 14 i ponad 7 p.p). Ponadto relatywnie największy wzrost odsetka gospodarstw domowych gromadzących oszczędności w gotówce wystapił w tym okresie w grupie gospodarstw zamieszkujących najmniejsze miasta, duże miasta o liczbie mieszkańców 200-500 tys. i wieś (odpowiednio o ponad 6 p.p, około 5 i prawie 4 p.p) oraz największych i dużych miast w przypadku lokat w udziały oraz akcje w prywatnych spółkach akcyjnych (odpowiednio o 3 i o ponad 2 p.p.). Odsetki gospodarstw posiadających oszczędności w gotówce znacząco wzrosły także w grupie gospodarstw domowych bez bezrobotnych.

Gospodarstwa domowe, które deklarowały posiadanie oszczędności w marcu 2011 r., najczęściej gromadziły je jako rezerwę na sytuacje losowe (ponad 60 proc.), zabezpieczenie na starość (ponad 35 proc. gospodarstw) oraz jako rezerwę na bieżące wydatki konsumpcyjne (ponad 33 proc. gospodarstw) (wykres 4.3.8).

W ostatnich czterech latach znacząco wzrósł odsetek gospodarstw domowych gromadzących oszczędności z przeznaczeniem na remont mieszkania (domu), (o ponad 6 p.p), wypoczynek i leczenie (po ponad 4 p.p) oraz zabezpieczenie na starość (o prawie 4 p.p) (wykres 4.3.9). W latach 2009-2011 nastąpił istotny wzrost oszczędności tylko w przypadku ich gromadzenia jako rezerwa na bieżące wydatki konsumpcyjne (o prawie 3 p.p, wykres 4.3.9).

Oszczędności gromadzone jako rezerwa na sytuacje losowe najczęściej występowały w marcu 2011 r. w gospodarstwach emerytów oraz w gospodarstwach domowych rencistów (deklarowało to odpowiednio ponad 63 proc. i prawie 62 proc. gospodarstw posiadających oszczędności, należących do tych grup społecznoekonomicznych). Ten cel gromadzenia oszczędności najczęściej był wymieniany przez gospodarstwa domowe rodzin niepełnych (przez prawie 71 proc. tego typu gospodarstw). Także w przypadku grup gospodarstw domowych z bezrobotnymi i bez bezrobotnych oszczędności najczęściej były gromadzone jako rezerwa na sytuacje losowe (odpowiednio w ponad 56 proc. i w ponad 60 proc. gospodarstw z tych grup). Zróżnicowanie grup gospodarstw gromadzących oszczędności jako rezerwa na sytuacje losowe nie było natomiast znaczące według klasy miejscowości zamieszkania oraz województw. Najczęściej ten cel oszczędzania występował w dużych miastach o liczbie mieszkańców 200-500 tys. (w prawie 64 proc. gospodarstw) oraz w województwach podlaskim i lubuskim (u ponad 80 i prawie 78 proc. gospodarstw).

W ostatnich dwóch latach najsilniejszy wzrost odsetka gospodarstw domowych gromadzących oszczędności jako rezerwę na sytuacje losowe wystąpił w grupach gospodarstw domowych utrzymujących się z niezarobkowych źródeł (o prawie 20 p.p), nierodzinnych wieloosobowych (o ponad 12 p.p), gospodarstwach zamieszkujaccych najmniejsze miasta (o ponad 7 p.p) oraz województwo podlaskie (o prawie 24 p.p). W tym samym okresie miał miejsce znaczący spadek odsetka gospodarstw domowych deklarujących ten cel oszczędzania w grupach gospodarstw domowych emerytów (o ponad 2 p.p), rodzin małżeństw $\mathrm{z} 1$ dzieckiem (o ponad 3 p.p), z bezrobotnymi (o ponad 7 p.p), zamieszkujących największe miasta (o około 8 p.p) oraz województwo opolskie (o prawie 21 p.p).

Zabezpieczenie na starość było najczęściej wskazywanym w marcu 2011 r. celem gromadzenia oszczędności przez gospodarstwa domowe emerytów i rencistów (u odpowiednio prawie 49 i prawie 41 proc. gospodarstw), gospodarstwa nierodzinne jednoosobowe (w ponad 41 proc. gospodarstw), gospodarstwa zamieszkujące największe miasta o liczbie mieszkańców powyżej 500 tys. (w ponad 40 proc. gospodarstw) oraz województwa mazowieckie i pomorskie (w ponad 42 proc. gospodarstw).

Odsetek gospodarstw domowych oszczędzających z myślą o zabezpieczeniu na starość spadł w skali ogólnopolskiej o ponad 3 p.p. w okresie marzec 2007-marzec 2011 (wykres 4.3.9). W ostatnich dwóch latach nie uległ on istotnym zmianom (wykres 4.3.10). Spadł on natomiast w tym okresie najbardziej w gospodarstwach utrzymujących się z niezarobkowych źródeł (o ponad 7 p.p) nierodzinnych wieloosobowych i rodzin niepełnych (o prawie 16 i około 4 p.p), zamieszkujących duże miasta o liczbie mieszkańców 200-500 tys. (o ponad 3 p.p) oraz województwa lubelskie, dolnośląskie i opolskie (odpowiednio o ponad 7 i po ponad 6 p.p), a także w grupie gospodarstw z bezrobotnymi (o prawie 8 p.p). Jednocześnie jego znaczące zwiększenie nastąpiło w grupie gospodarstw domowych rencistów (o prawie 8 p.p), małżeństw z 1 dzieckiem (o prawie 6 p.p), zamieszkujących najmniejsze miasta (o ponad 5 p.p) oraz w województwie świętokrzyskim (o prawie 14 p.p).

Wśród grup społeczno-ekonomicznych najczęściej oszczędności z przeznaczeniem na bieżące wydatki konsumpcyjne gromadziły w marcu 2011 r. gospodarstwa domowe utrzymujących się z niezarobkowych źródeł i rolników (odpowiednio prawie 67 proc. i prawie 44 proc. gospodarstw z tych grup). Natomiast wśród typów gospodarstw domowych ten cel przeznaczenia oszczędności wskazywały przede wszystkim gospodarstwa domowe małżeństw wielodzietnych (ponad 44 proc. gospodarstw). Najczęściej gromadziły oszczędności jako rezerwę na bieżące wydatki konsumpcyjne gospodarstwa zamieszkujące wieś (prawie 39 proc. gospodarstw) oraz województwo wielkopolskie (około 45 proc. gospodarstw) i województwo podkarpackie (około 44 proc. gospodarstw). Także w grupie gospodarstw domowych z bezrobotnymi ten cel gromadzenia oszczędności był dość powszechny (w około 47 proc. gospodarstw gromadzono oszczędności na ten cel). 


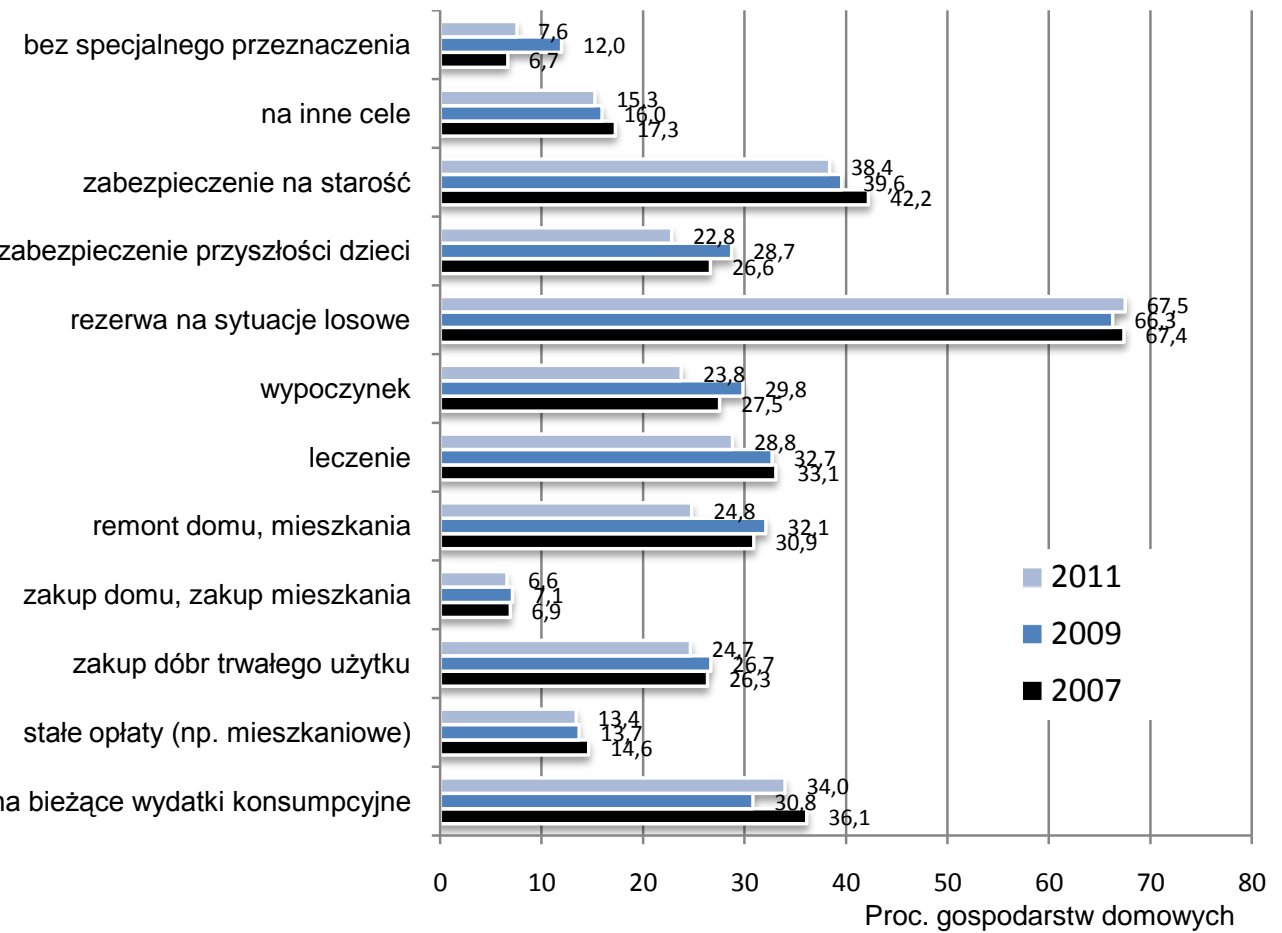

Wykres 4.3.8. Cele gromadzenia oszczędności przez gospodarstwa domowe, które posiadaja oszczędności, w latach 2007-2011 w próbie panelowej.

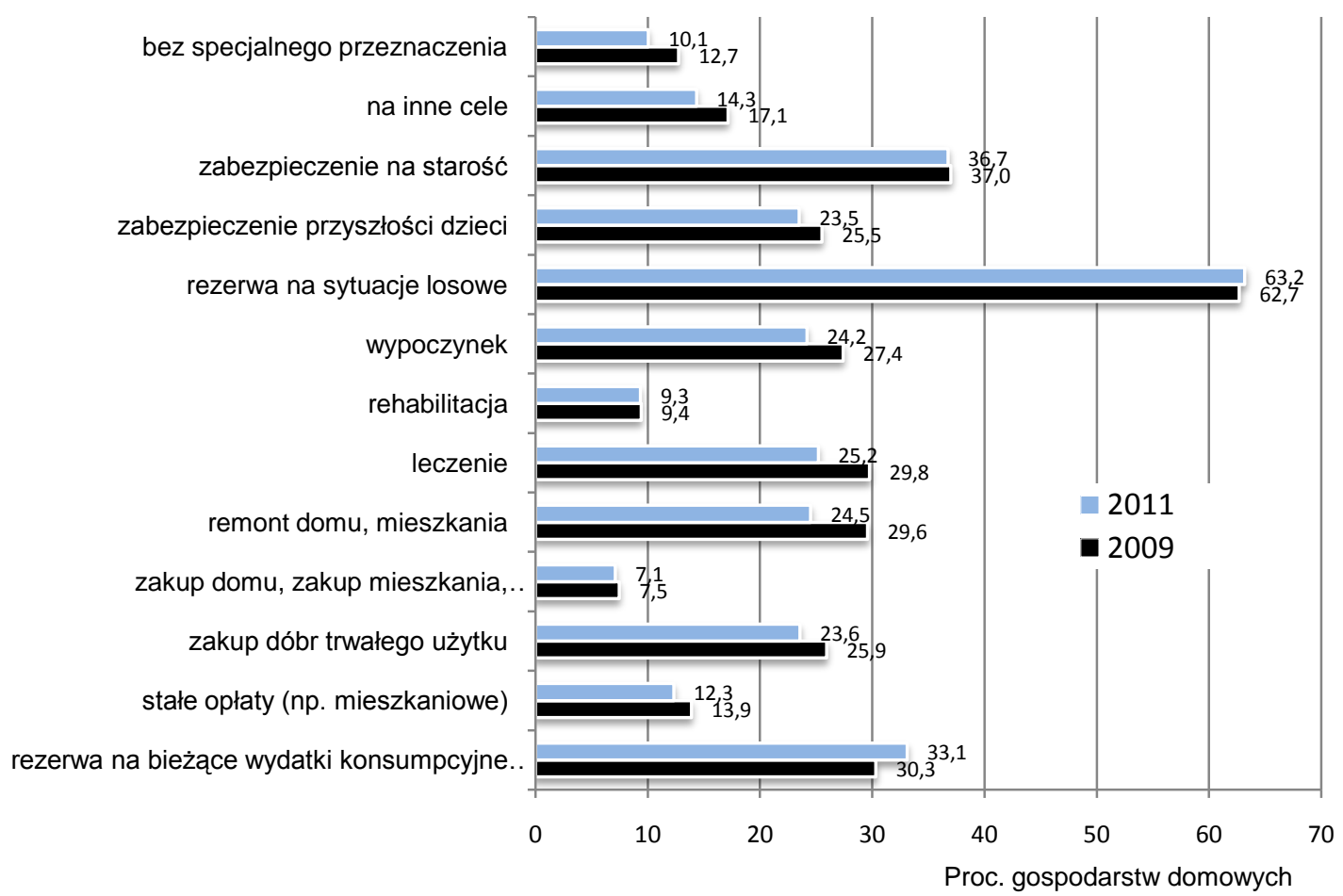

Wykres 4.3.9. Cele gromadzenia oszczędności przez gospodarstwa domowe, które posiadaja oszczędności, w 2009 i 2011 r. w próbie panelowej.

Relatywnie największy przyrost oszczędności traktowanych jako rezerwa na bieżące wydatki konsumpcyjne obserwujemy w ostatnich dwóch latach w grupie gospodarstw domowych utrzymujących się z niezarobkowych źródeł (o prawie 11 p.p), rodzin niepełnych (o około 9 p.p) oraz zamieszkujących największe miasta (o prawie 7 p.p) i województwo wielkopolskie (o ponad 14 p.p). W tym samym okresie relatywnie najsilniejszy spadek oszczędzania na ten cel nastapił w grupach gospodarstw domowych rolników (o prawie 6 p.p), z bezrobotnymi (o prawie 5 p.p), gospodarstw nierodzinnych wieloosobowych (o ponad 11 p.p) oraz zamieszkujących województwo lubelskie (o ponad 11 p.p) a także województwo lubuskie (o ponad 9 p.p). 
Ponad 39 proc. badanych gospodarstw domowych deklarowało w marcu 2011 r. korzystanie z pożyczek i kredytów. Zadłużenie gospodarstw domowych najczęściej wynosiło powyżej ich rocznych dochodów (zadłużenie w tej wysokości zgłaszało prawie 23 proc. zadłużonych gospodarstw). Odsetek gospodarstw domowych korzystających z pożyczek i kredytów w okresie marzec 2007-marzec 2011 znacząco spadł (o ponad 6 p.p, wykres 4.3.10). W ostatnich dwóch latach odsetek gospodarstw korzystających z kredytów lub pożyczek spadł o prawie 4 p.p. (wykres 4.3.11). Zadłużenie w tym okresie wzrosło tylko w grupie gospodarstw domowych utrzymujących się $\mathrm{z}$ niezarobkowych źródeł (o prawie 2 p.p).

W marcu 2011 r. zadłużone były przede wszystkim gospodarstwa domowe pracowników oraz pracujących na własny rachunek (odpowiednio prawie 49 i ponad 47 proc. gospodarstw z tych grup). Wśród typów gospodarstw domowych najwyższy procent zadłużonych występował w grupie gospodarstw małżeństw z 2 dzieci oraz małżeństw wielodzietnych (odpowiednio prawie 52 i ponad 50 proc. gospodarstw w tych grupach). Zadłużenie gospodarstw domowych z bezrobotnymi było takie same jak gospodarstw domowych bez bezrobotnych (po około 39 proc. gospodarstw z tych grup).

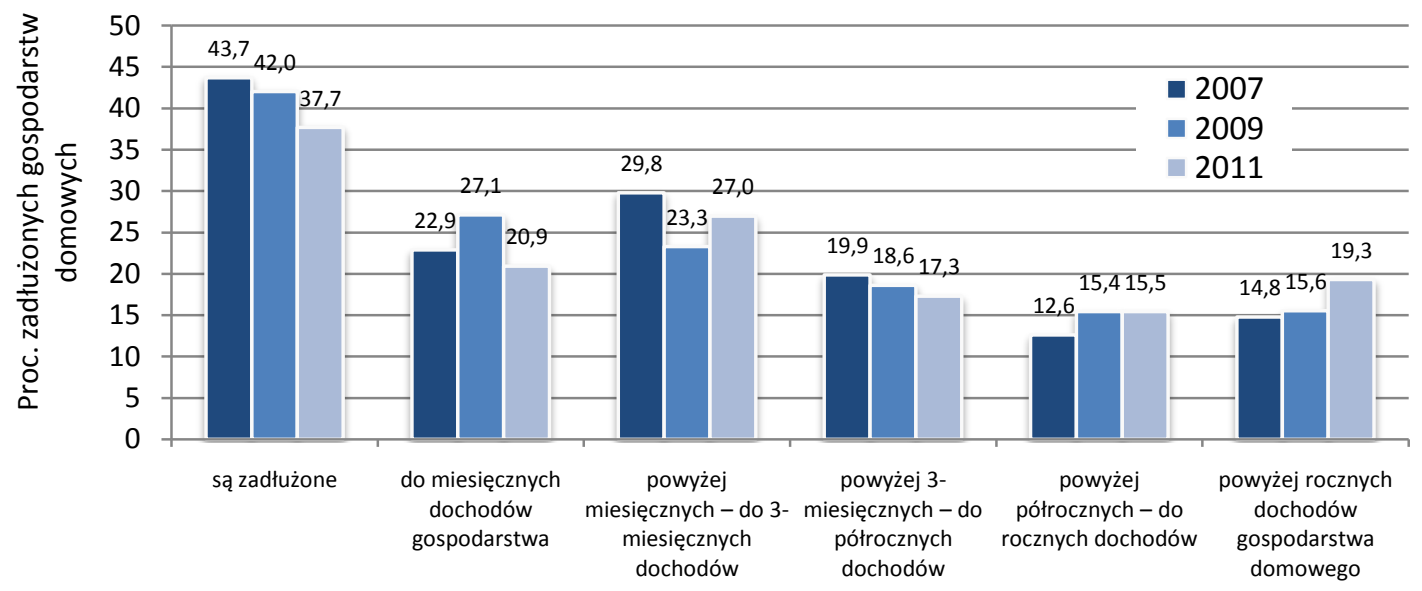

Stan i skala zadłużenia

Wykres 4.3.10. Stan zadtużenia gospodarstw domowych i skala tego zadtużenia wśród zadtużonych gospodarstw w latach 2007-2011 w próbie panelowej.

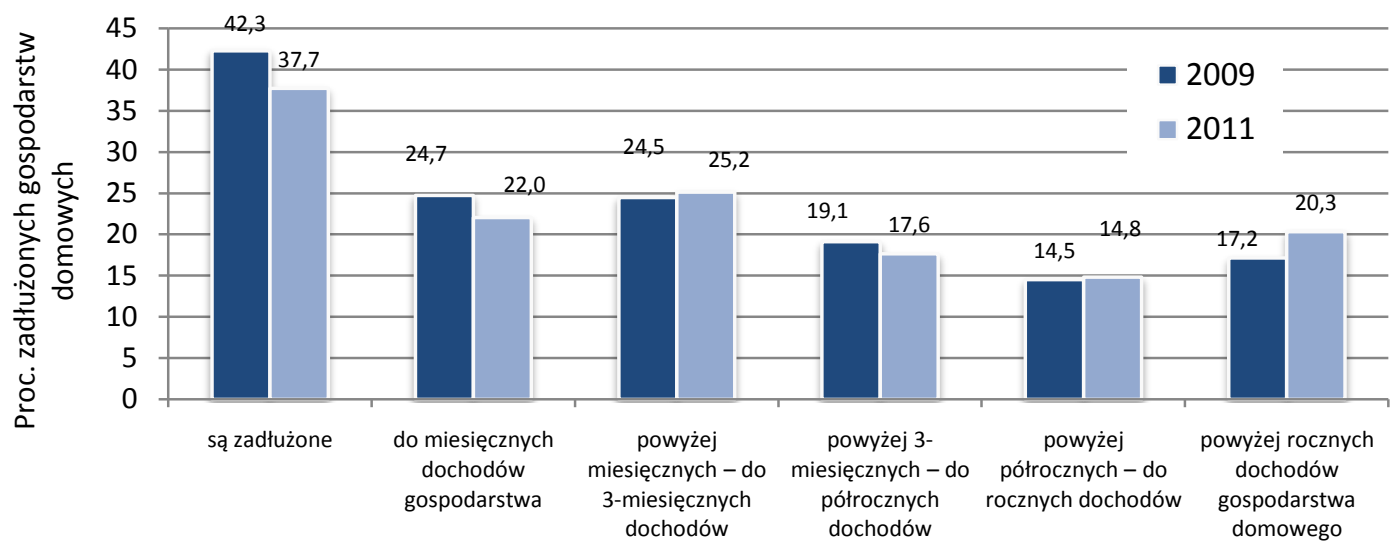

Stan i skala zadłużenia

Wykres 4.3.11. Stan zadtużenia gospodarstw domowych i skala tego zadtużenia wśród zadtużonych gospodarstw w 2009 i 2011 r. w próbie panelowej.

Częstość występowania zadłużenia gospodarstw domowych według klas miejscowości zamieszkania oraz województw jest stosunkowo mało zróżnicowana. Najwyższy procent gospodarstw domowych zadłużonych występuje w miastach o liczbie mieszkańców 100-200 tys. (ponad 42 proc. gospodarstw) a najniższy na wsi (ponad 36 proc. gospodarstw). Największy procent zadłużonych gospodarstw jest w województwach dolnośląskim i lubuskim (odpowiednio około 51 i prawie 48 proc. gospodarstw), a najmniejszy w województwach świętokrzyskim i podlaskim (odpowiednio około 27 i 30 proc. gospodarstw).

Źródłem zewnętrznego zasilania finansowego dla około 90 proc. zadłużonych gospodarstw domowych były banki, a dla prawie 13 proc. inne instytucje. Tylko niecałe 6 proc. gospodarstw było zadłużonych u osób prywatnych. W okresie marzec 2007-marzec 2011 nieznacznie, o po ponad 1 punkt procentowy, zwiększył się odsetek gospodarstw domowych korzystających z kredytów w bankach i u osób prywatnych przy jednoczesnym 
spadku, o prawie 6 p.p, korzystających z pożyczek w innych instytucjach (wykres 4.3.12). W ostatnich dwóch latach wzrósł znacząco odsetek gospodarstw domowych korzystających z pożyczek u osób prywatnych (o prawie 2 p.p), przy czym relatywnie najsilniej w grupach gospodarstw utrzymujących się z niezarobkowych źródeł i pracujących na własny rachunek (odpowiednio o prawie 21 i ponad 8 p.p) z bezrobotnymi (o około 4 p.p), wieloosobowych (o ponad 7 p.p), zamieszkujących małe miasta o liczbie mieszkańców 20-100 tys. (o około 5 p.p) oraz województwa warmińsko-mazurskie i opolskie (odpowiednio o prawie 9 i prawie 7 p.p, wykres 4.3.13).

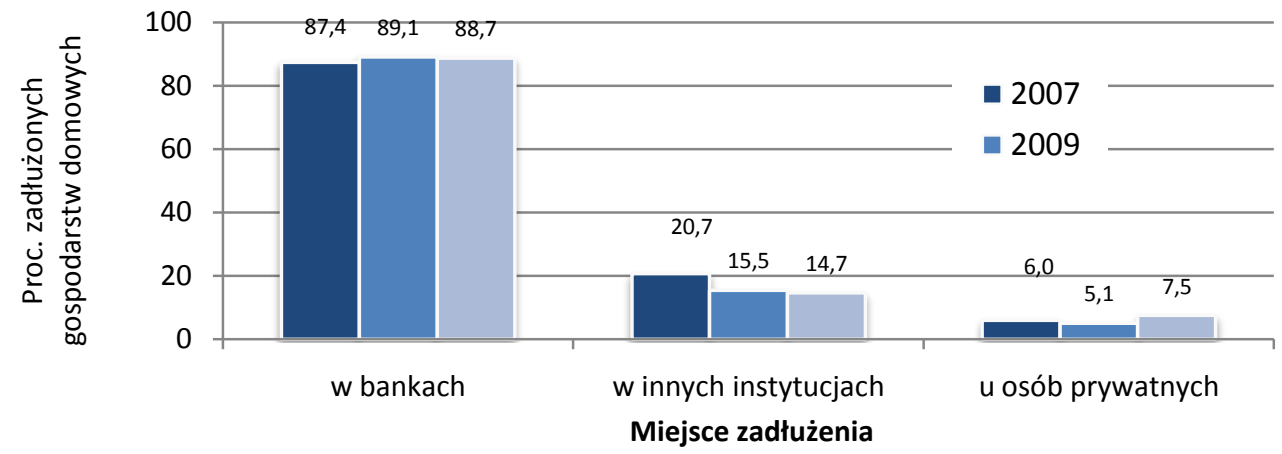

Wykres 4.3.12. Miejsca zadtużenia gospodarstw domowych w latach 2007-2011 w próbie panelowej.

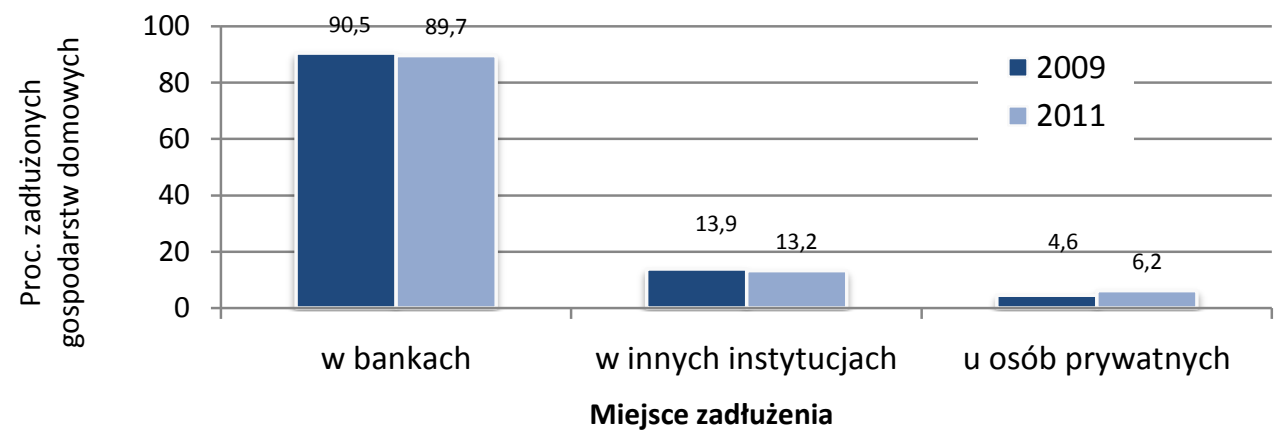

Wykres 4.3.13. Miejsca zadtużenia gospodarstw domowych w 2009i 2011 r. w próbie panelowej.

Pożyczki w bankach były najbardziej rozpowszechnione w gospodarstwach zamieszkujących największe miasta (ponad 94 proc. zadłużonych gospodarstw) oraz w województwach podlaskim i zachodnio-pomorskim (odpowiednio ponad 95 i prawie 94 proc. zadłużonych gospodarstw).

Z pożyczek w instytucjach innych niż banki najczęściej korzystały gospodarstwa domowe pracowników (około 15 proc. zadłużonych gospodarstw), rodzin niepełnych (ponad 24 proc. zadłużonych gospodarstw), zamieszkujących duże miasta liczące 200-500 tys. mieszkańców (ponad 18 proc. zadłużonych gospodarstw) oraz województwa lubelskie i lubuskie (odpowiednio ponad 17 i prawie 17 proc. zadłużonych gospodarstw). Natomiast gospodarstwa domowe utrzymujących się z niezarobkowych źródeł (ponad 26 proc. zadłużonych gospodarstw), z bezrobotnymi (ponad 11 proc. zadłużonych gospodarstw), rodzin niepełnych (ponad 10 proc. zadłużonych gospodarstw), zamieszkujące małe miasta, liczące 20-100 tys. mieszkańców, (ponad 7 proc. zadłużonych gospodarstw) oraz województwa warmińsko-mazurskie i lubuskie (prawie 11 i ponad 8 proc. zadłużonych gospodarstw) relatywnie najczęściej korzystały z pożyczek od osób prywatnych.

Dla rozpoznania przeznaczenia zewnętrznego zasilania finansowego gospodarstw poddano badaniu cele wykorzystania zaciagniętych przez gospodarstwa domowe kredytów i pożyczek. Ponad 37 proc. gospodarstw badanych w marcu 2011 r. kredyty i pożyczki wykorzystało na sfinansowanie zakupu dóbr trwałego użytku, około 32 proc. gospodarstw wykorzystało pożyczki i kredyty na remont domu lub mieszkania, a około 18 proc. gospodarstw domowych przeznaczyło kredyt na zakup domu lub mieszkania. W okresie marzec 2007-marzec 2011 obserwujemy relatywnie największy wzrost odsetka gospodarstw domowych zaciagających kredyty z przeznaczeniem na stałe opłaty (o prawie 6 p.p), leczenie i bieżące wydatki konsumpcyjne (po prawie 5 p.p) (wykres 4.3.14). W ostatnich dwóch latach nastąpił znaczący wzrost odsetka gospodarstw domowych zaciągających kredyty i pożyczki tylko z przeznaczeniem spłat wcześniejszych długów oraz na bieżące wydatki konsumpcyjne (po ponad 1 punkt procentowy) (wykres 4.3.15).

W marcu 2011 gospodarstwa domowe deklarowały, że najczęściej kredyty na zakup dóbr trwałego użytku zaciągały gospodarstwa domowe pracowników (ponad 39 proc. gospodarstw korzystających z kredytów). Na remont domu lub mieszkania relatywnie najczęściej wykorzystywały kredyty gospodarstwa domowe pracowników rencistów oraz emerytów (odpowiednio prawie 35 i ponad 33 i prawie 33 proc.). Zakup domu lub mieszkania był głównym przeznaczeniem kredytów przede wszystkim w gospodarstwach pracujących na własny rachunek gospodarstwach domowych (w ponad 32 proc. gospodarstw korzystających z kredytów). 
Istotnym źródłem finansowym zakupu dóbr trwałego użytku, uwzględniając klasyfikację według typu gospodarstwa domowego, były kredyty i pożyczki zaciągnięte przez przede wszystkim gospodarstwa wielorodzinne i nierodzinne jednoosobowe (w po przeszło 41 proc. gospodarstw korzystających z kredytów). Dla gospodarstw domowych wielorodzinnych kredyt był także ważnym źródłem finansowania remontu domu lub mieszkania (w ponad 41 proc. gospodarstw korzystających z kredytów). Natomiast zakup domu lub mieszkania najczęściej był finansowany poprzez kredyty i pożyczki w gospodarstwach domowych małżeństw z 1 dzieckiem (w ponad 27 proc. gospodarstw korzystających z kredytów).

W przypadku grupy gospodarstw bez bezrobotnych pożyczki i kredyty były najczęściej, podobnie jak w całej populacji gospodarstw, zaciaggane przede wszystkim na zakup dóbr trwałego użytku, na remont domu lub mieszkania oraz na zakup domu lub mieszkania (odpowiednio w ponad 37 proc., w prawie 32 proc. oraz w ponad 19 proc. gospodarstw korzystających z kredytów w tej grupie). Zakup dóbr trwałego użytku był także najczęstszym celem pożyczek i kredytów w gospodarstwach z bezrobotnymi (w prawie 38 proc. gospodarstw korzystających z kredytów). Kolejnymi najczęstszymi celami zaciągania kredytów i pożyczek w tej grupie gospodarstw był remont domu lub mieszkania oraz bieżące wydatki konsumpcyjne (odpowiednio około 35 proc. i ponad 28 proc. gospodarstw korzystających z kredytów w tej grupie zaciagało je na te cele).

Zakup dóbr trwałego użytku był najczęściej finansowany z kredytów i pożyczek przez gospodarstwa domowe zamieszkujące duże miasta o liczbie mieszkańców 200-500 tys. (w ponad 43 proc. gospodarstw korzystających z kredytów) oraz województwo świętokrzyskie (w prawie 45 proc. gospodarstw korzystających z kredytów). Na remont domu lub mieszkania najczęściej kredyty przeznaczały gospodarstwa zamieszkujące najmniejsze miasta $\mathrm{i}$ wieś (odpowiednio około 39 i prawie 36 proc. gospodarstw korzystających z kredytów) oraz województwa opolskie i małopolskie (w po ponad 40 proc. gospodarstw korzystających z kredytów). Natomiast na zakup domu lub mieszkania najczęściej wykorzystywały kredyty i pożyczki mieszkańcy największych miast o liczbie mieszkańców powyżej 500 tys. (prawie 31 proc. gospodarstw korzystających z kredytów) oraz województwa mazowieckiego (prawie 29 proc. gospodarstw korzystających z kredytów).

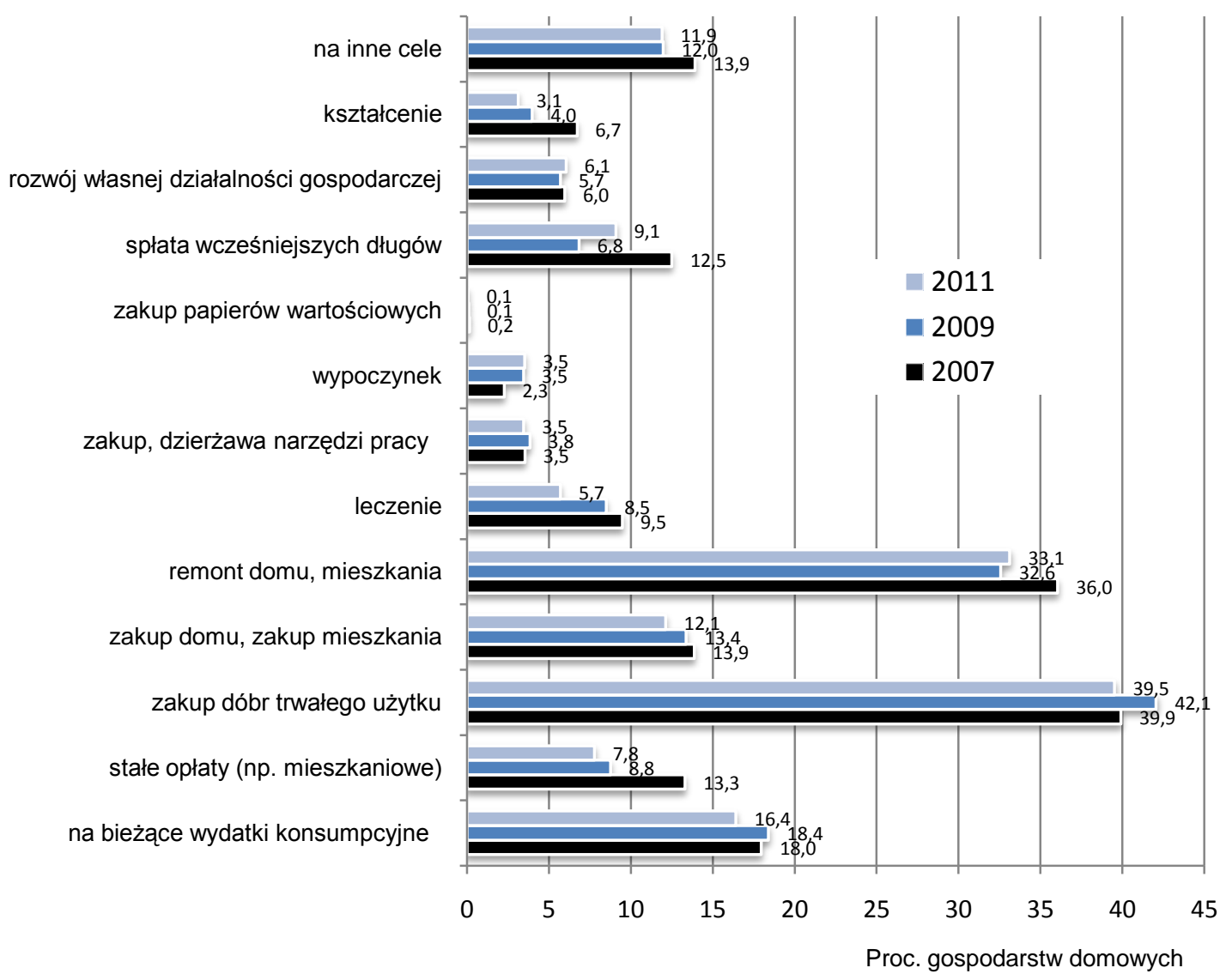

Wykres 4.3.14. Cele zaciagniętych przez gospodarstwa domowa kredytów i pożyczek wśród gospodarstw zadtużonych $w$ latach 2007-2011 w próbie panelowej. 


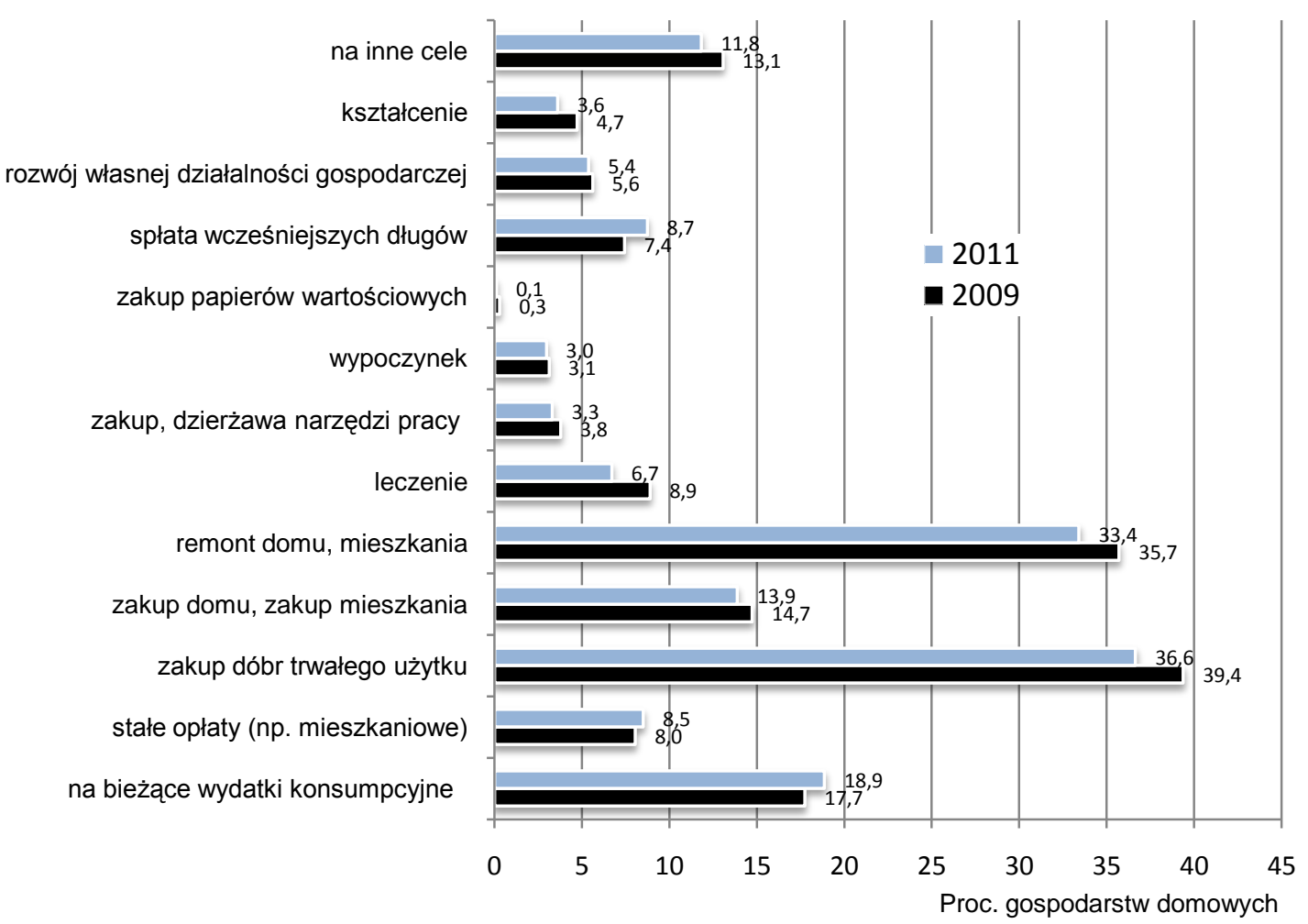

Wykres 4.3.15. Cele zaciagniętych przez gospodarstwa domowa kredytów i pożyczek wśród gospodarstw zadtużonych w 2009 i 2011 r. w próbie panelowej.

Oceniając zmiany swojej zasobności materialnej w marcu 2011 r. w porównaniu do sytuacji sprzed dwóch lat prawie 57 proc. gospodarstw stwierdziło, że nie zmieniła się, a ponad 32 proc., że uległa pogorszeniu. W stosunku do cen formułowanych w marcu 2009 r. znacząco spadł odsetek gospodarstw domowych oceniających zmiany zarówno pozytywnie (o prawie 4 p.p) jak i negatywnie (o prawie 2 p.p). Najczęściej oceny negatywne tych zmian dawały w marcu 2011 r. gospodarstwa domowe utrzymujących się z niezarobkowych źródeł i rencistów (odpowiednio ponad 47 i prawie 35 proc. gospodarstw) oraz gospodarstwa rodzin niepełnych (ponad 37 proc. gospodarstw). Widoczna jest wśród negatywnie oceniających zmianę znacząca względna przewaga częstości występowania gospodarstw domowych $\mathrm{z}$ bezrobotnymi w stosunku do gospodarstw bez bezrobotnych (odpowiednio prawie 46 i ponad 30 proc. gospodarstw). Gospodarstwa wskazujące na pogorszenie się sytuacji materialnej zamieszkiwały przede wszystkim duże miasta o liczbie mieszkańców 200-500 tys. (ponad 34 proc. gospodarstw) oraz województwa lubelskie (prawie 40 proc. gospodarstw) i opolskie (prawie 37 proc. gospodarstw).

\subsubsection{Zmiana zasobności materialnej w latach 2000-2011 \\ Janusz Czapiński}

Z wyjątkiem telefonu stacjonarnego, który rozpowszechniał się do roku 2003, po czym jego zakres zaczął coraz szybciej spadać do poziomu 54 proc. gospodarstw, we wszystkich innych dobrach trwałego użytku nastapił wzrost ich obecności w gospodarstwach domowych (wykres 4.3.16); największy w nowoczesnych technologiach komunikacyjnych. Obecnie dostęp do internetu ma ponad 60 proc., tj. cztery razy więcej gospodarstw domowych niż w 2003 r., odsetek gospodarstw z komputerem stacjonarnym wzrósł w 2009 r. ponad czterokrotnie od 2000 r., ale ostatnio wypierać go zaczął komputer przenośny (trzynastokrotny wzrost od 2005 r.). Także wyposażenie gospodarstw domowych w nowoczesny sprzęt ADG rośnie dynamicznie: kuchenka mikrofalowa - wzrost 3,5krotny od 2000 r., zmywarka - wzrost ponad sześciokrotny w minionym jedenastoleciu, pralka automatyczna wzrost o 22 p.p. do poziomu 91 proc. gospodarstw. O chłodziarkę i kineskopowy telewizor przestaliśmy wręcz pytać, ponieważ wszystkie gospodarstwa, w których jest taka potrzeba, były już w takie urządzenia niewyposażone. Obecnie połowa gospodarstw ma już nowoczesny telewizor płaski, a 70 proc. (wzrost o 24 p.p.) korzysta z płatnej telewizji kablowej lub satelitarnej. Samochód posiada obecnie prawie $2 / 3$ gospodarstw (o 40 proc. więcej niż $\mathrm{W}$ 2000 r.) 


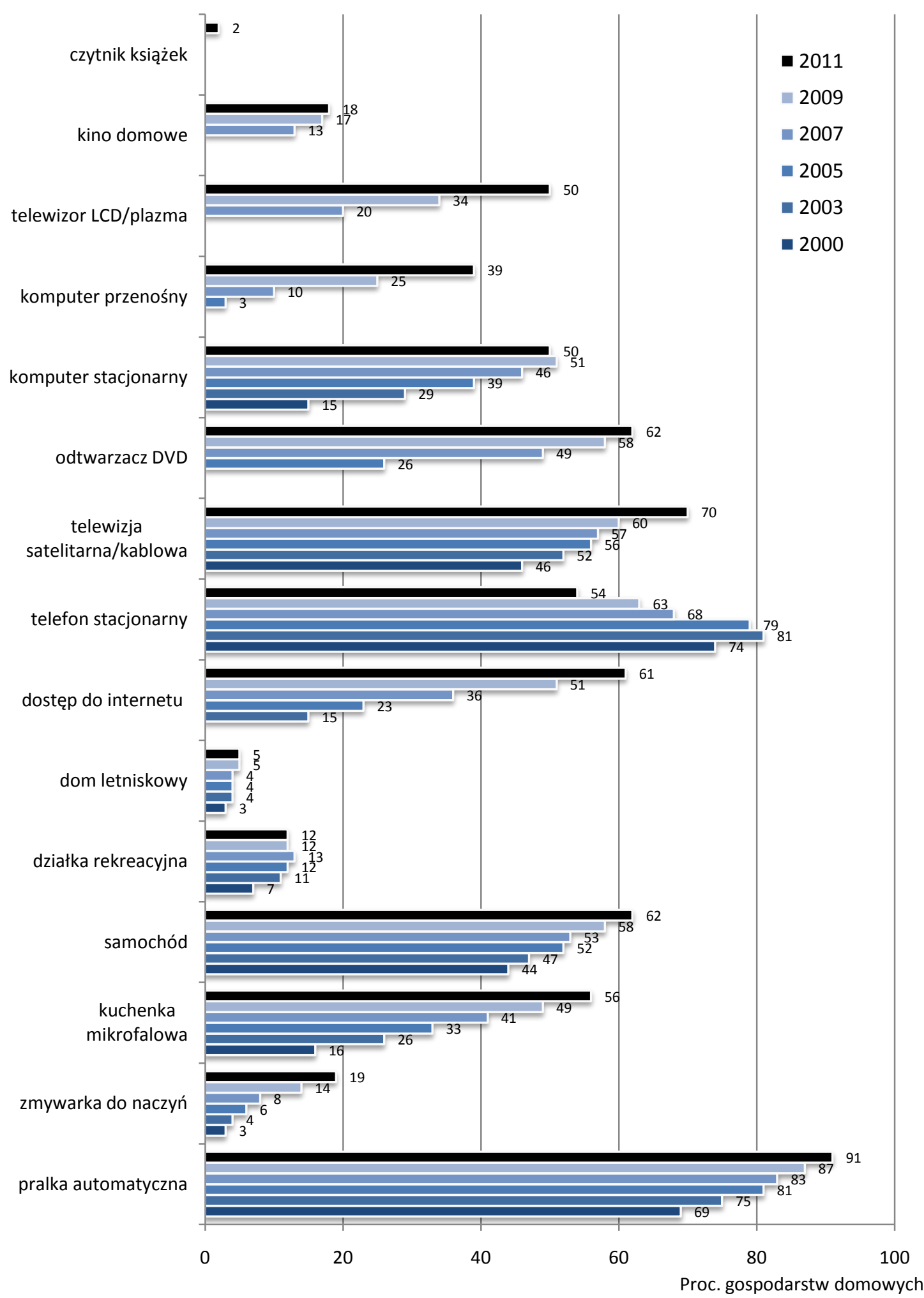

Wykres 4.3.16. Wyposażenie gospodarstw domowych $w$ wybrane dobra trwałego użytku w latach 2000-2011

Spada w odniesieniu do większości dóbr trwałego użytku odsetek gospodarstw, które ich nie mają z powodu trudności finansowych (wykres 4.3.17). Dzisiaj coraz częściej brak potrzeb, a nie pieniędzy, decyduje o nieposiadaniu pewnych dóbr. Dotyczy to głównie telefonu stacjonarnego (zastapionego przez telefon komórkowy), komputera stacjonarnego, samochodu i kuchenki mikrofalowej. 


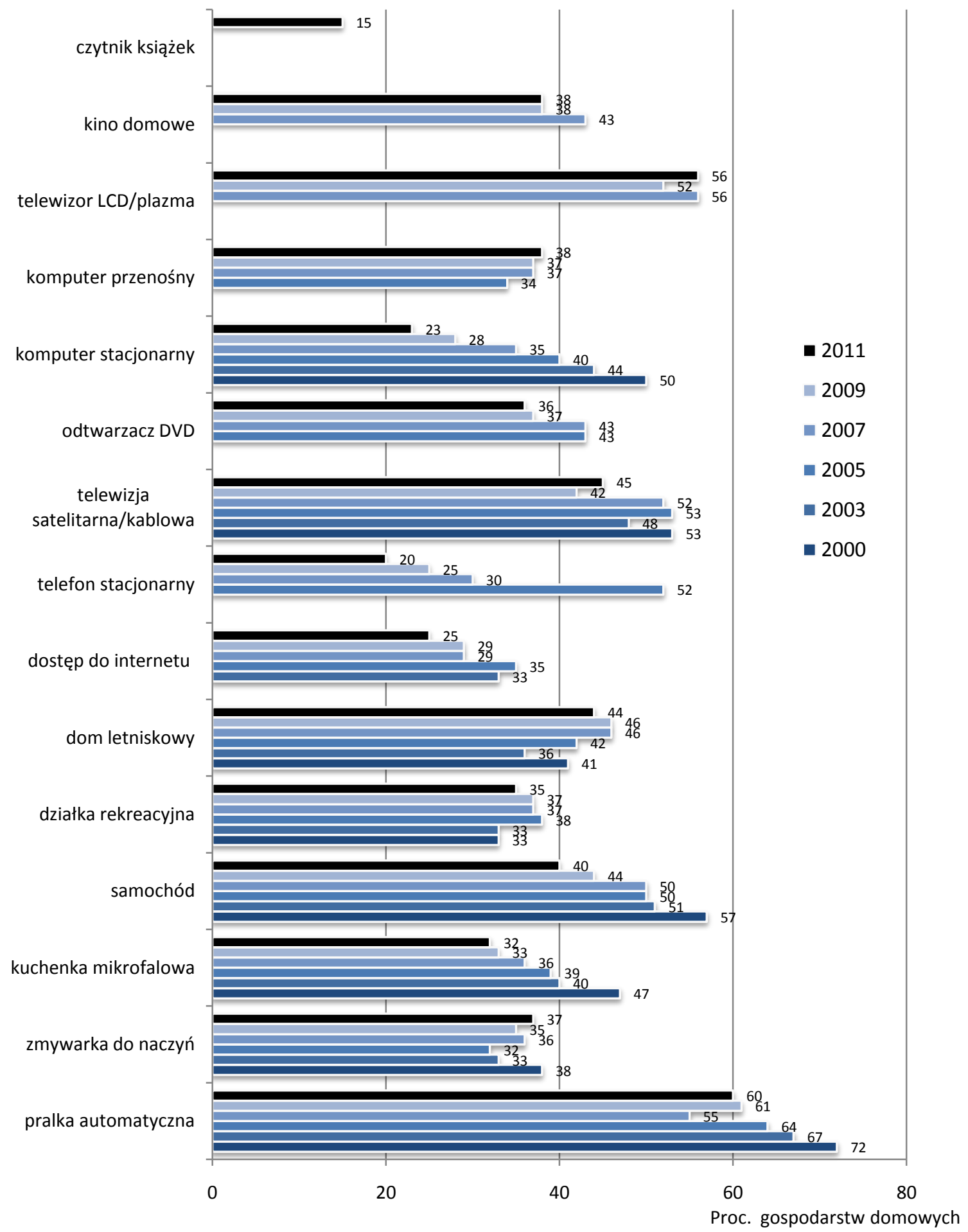

Wykres 4.3.17. Procent gospodarstw, w których brak dóbr wynika z braku środków finansowych na ich zakup w latach 2000-2011

W porównaniu do 2007 r. wzrósł odsetek gospodarstw domowych, które mają więcej niż jeden: samochód (z 11,3 do 21,9 proc.), komputer stacjonarny (z 2,7 do 5,8 proc.) i komputer przenośny (z 6,9 do 16,9 proc.).

O ponad połowę wzrósł od 2000 r. (do 37 proc.) odsetek gospodarstw, które mają jakieś oszczędności (wykres 4.3.18). Wśród posiadających oszczędności nie zmieniła się zasadniczo od 2000 r. struktura wysokości oszczędności. W dalszym ciągu dominują gospodarstwa $\mathrm{z}$ oszczędnościami w wysokości do trzymiesięcznych dochodów. Odsetek posiadających oszczędności w wysokości powyżej rocznych dochodów pozostał na tym samym niskim poziomie 8 proc., co oznacza w populacji wszystkich gospodarstwach domowych zaledwie 3 proc. 


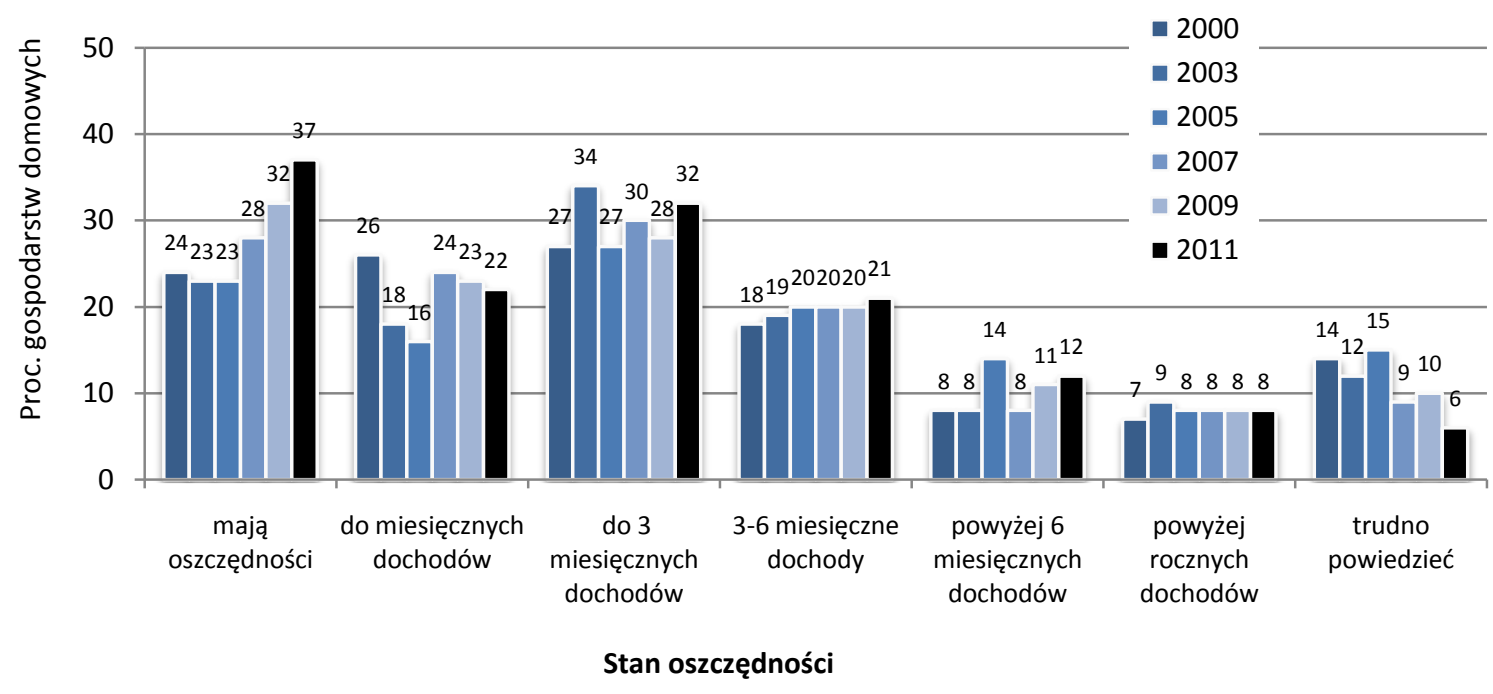

Wykres 4.3.18. Procent gospodarstw posiadających oszczędności i odsetek gospodarstw z różna wysokościq oszczędności wśród wszystkich posiadajacych oszczędności w latach 2000-2011

Nie zmieniają się też w zasadzie formy oszczędności (wykres 4.3.19). Warto jednak zauważyć, że w porównaniu z latami poprzedzającymi światowy kryzys finansowy (2005-2007) spadł udział oszczędności w postaci lokat w funduszach inwestycyjnych, w nieruchomościach i na Indywidualnych Kontach Emerytalnych, a wzrosły bezpieczne lokaty złotowe w bankach (choć ich udział ciągle nie osiągnął poziomu z początku wieku).

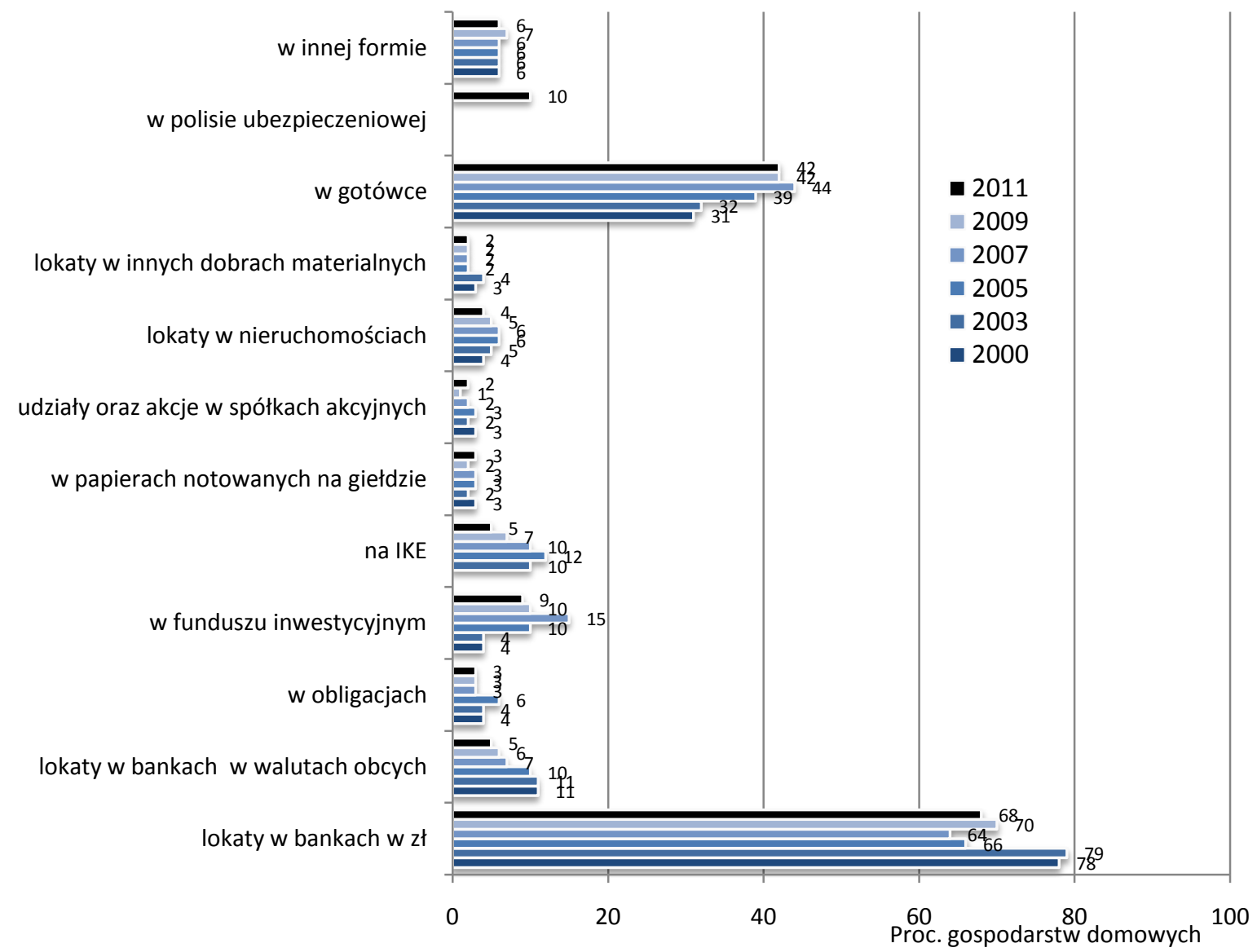

Wykres 4.3.19. Formy oszczędności gospodarstw domowych w latach 2000-2011

Jeśli chodzi o cel przeznaczenia oszczędności, spada udział gospodarstw oszczędzających na sytuacje losowe, zabezpieczenie na starość, leczenie, zakup dóbr trwałego użytku, wypoczynek i remont domu (wykres 4.3.20). 


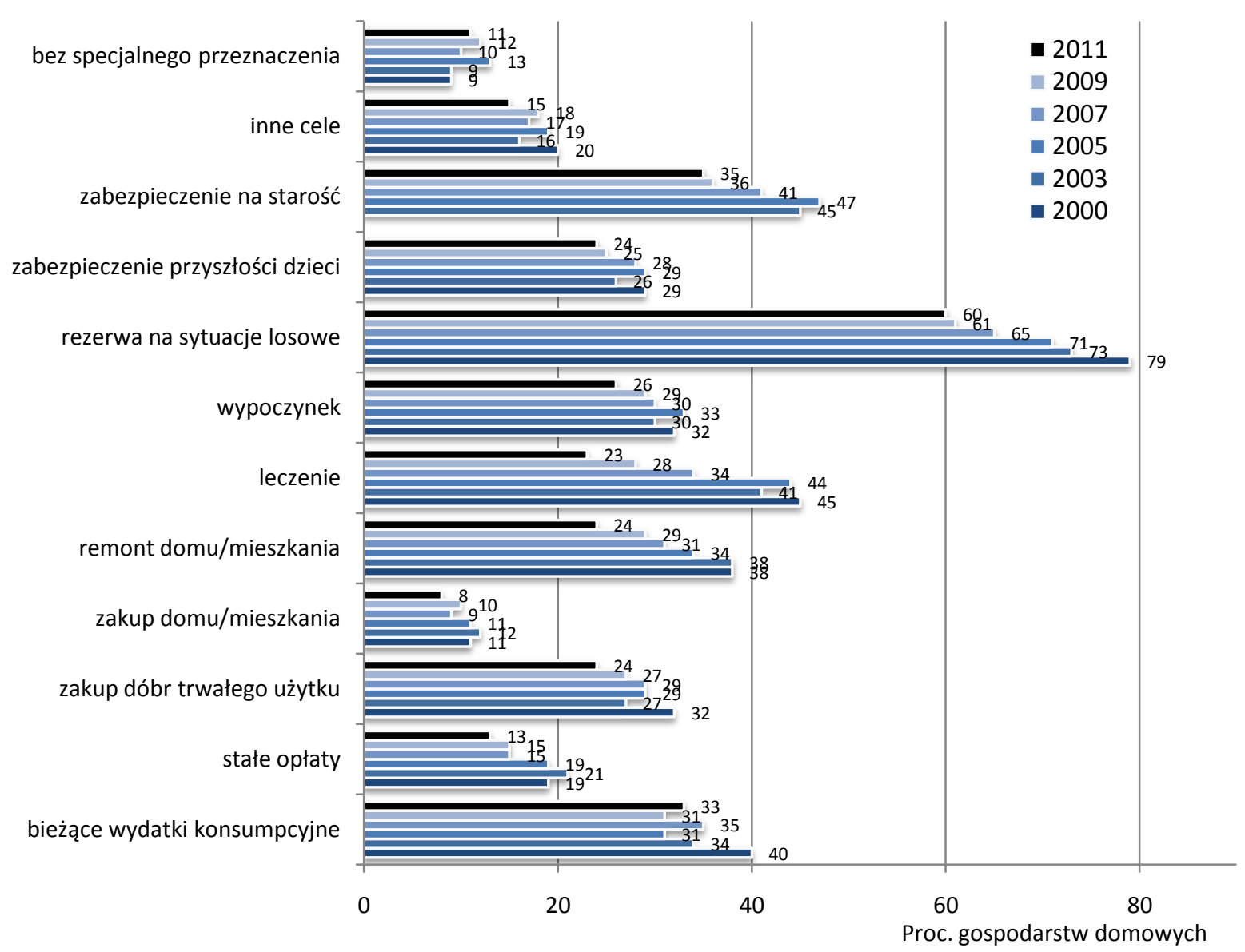

Wykres 4.3.20. Cele gromadzenia oszczędności przez gospodarstwa domowe, które posiadaja oszczędności, w latach 2000-2011

Nieco (z 42 do 39 proc.) spadła w ostatnich czterech latach liczba gospodarstw zadłużonych, przy czym spadł znacząco odsetek gospodarstw zadłużonych w wysokości do trzymiesięcznych dochodów, a wzrósł procent gospodarstw zadłużonych w wysokości powyżej rocznych dochodów (z 8 proc. w 2000 r. i 19 proc. w 2009 do 23 proc.) (wykres 4.3.21).

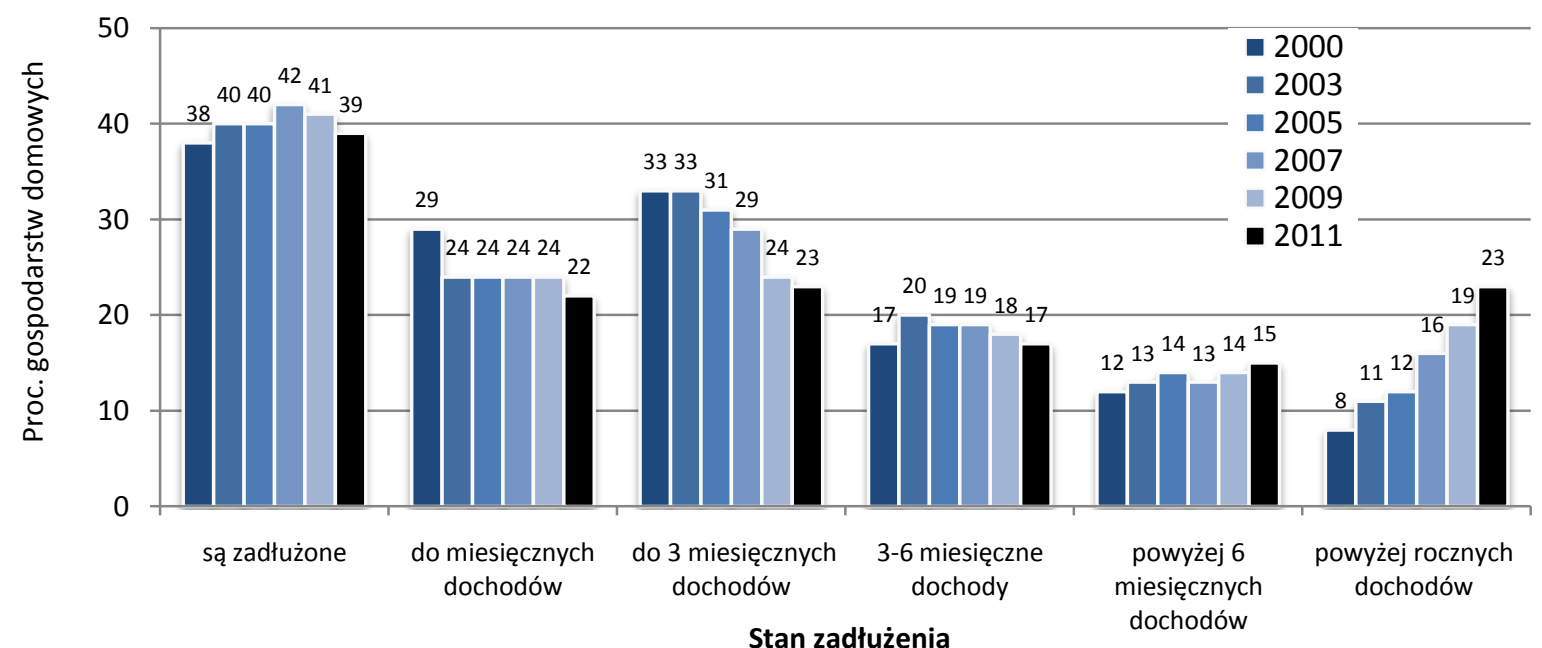

Wykres 4.3.21. Odsetek gospodarstw zadtużonych i odsetek gospodarstw o różnej wysokości zadtużenia wśród zadtużonych w latach 2000-2011

Znacząco i systematycznie rosło od początku wieku zadłużenie gospodarstw domowych w bankach (od 73 proc. w 2000 r. do 91 proc. w 2009 r. i 90 proc. w 2011 r.) kosztem zadłużenia w innych instytucjach finansowych (wykres 4.3.22). 


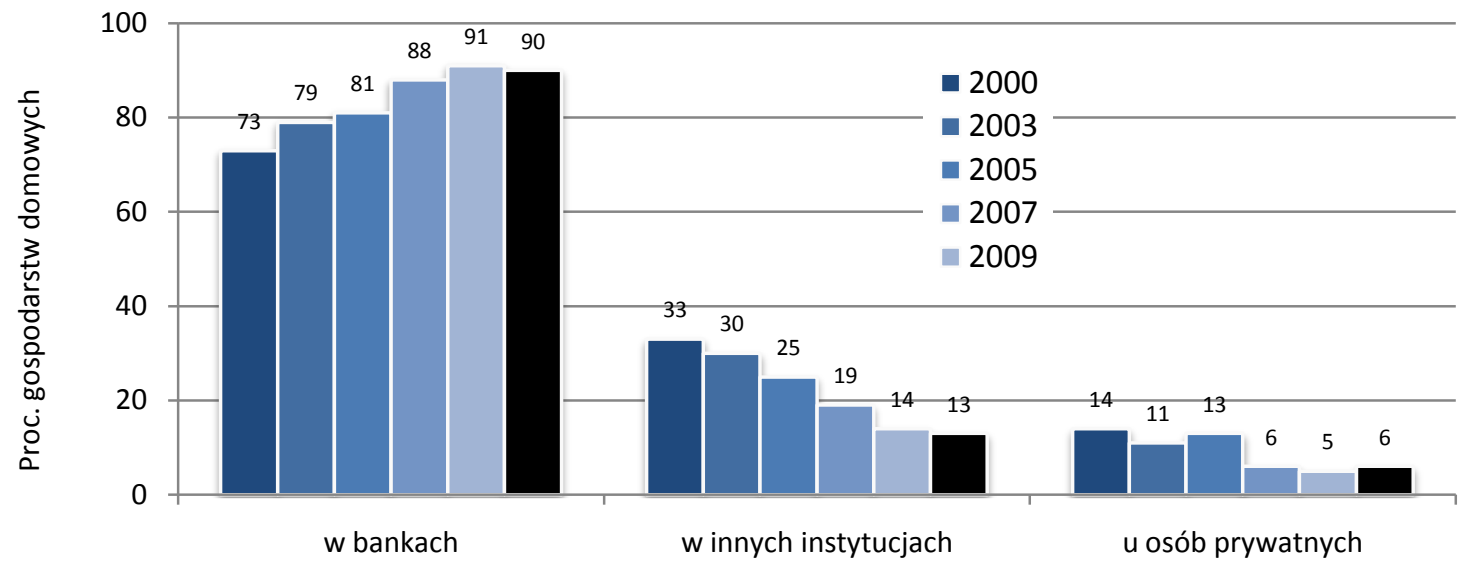

Miejsce zadłużenia

Wykres 4.3.22. Miejsca zadtużenia gospodarstw domowych $w$ latach 2000-2011

Kredyty i pożyczki są coraz rzadziej przeznaczane na leczenie, kształcenie i stałe opłaty (np. mieszkaniowe), a coraz częściej na zakup domu lub mieszkania (4.3.23). W połączeniu ze zmianą wysokości zadłużenia oznacza to spadek kredytów konsumenckich i wzrost kredytów hipotecznych.

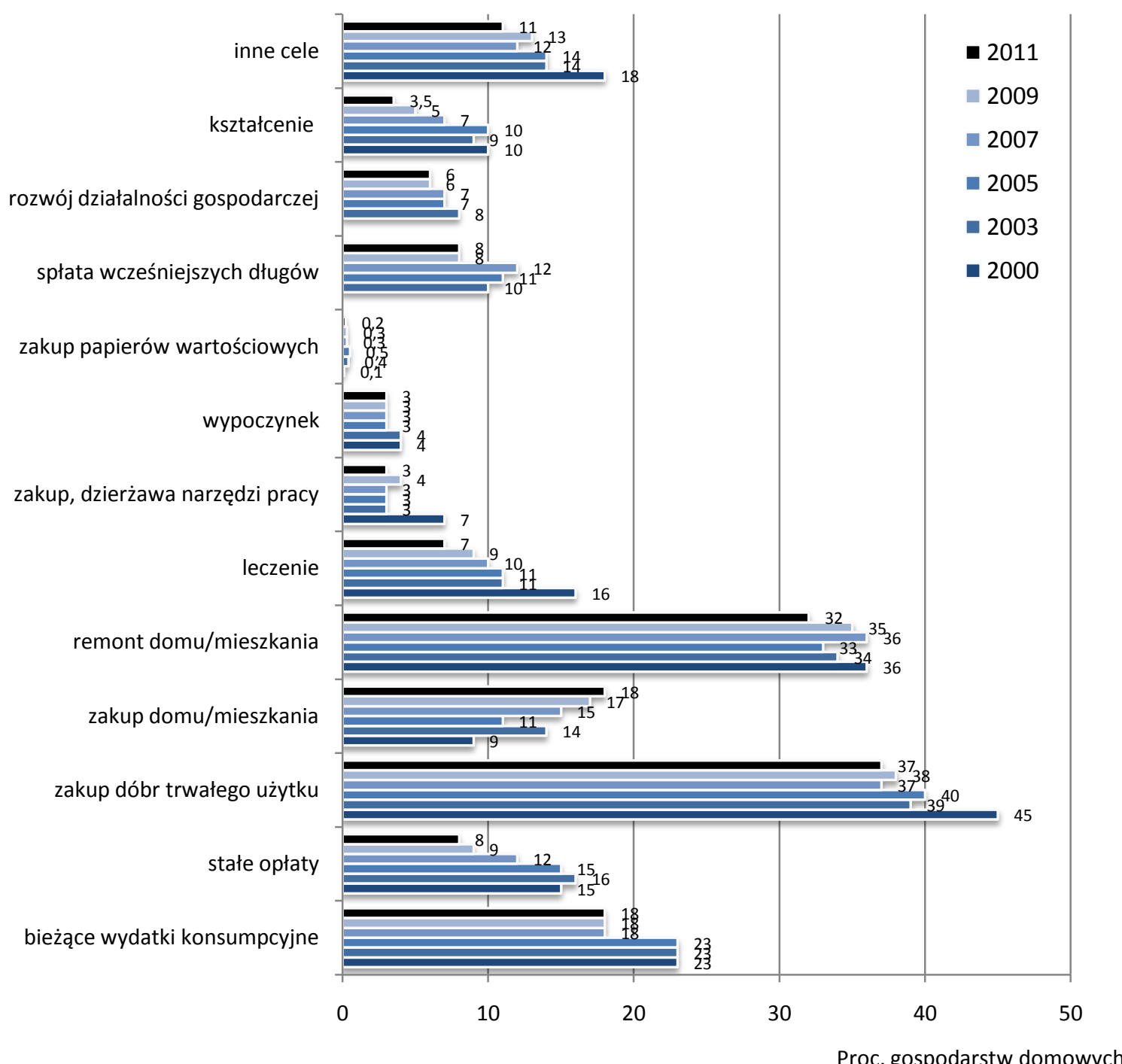

Wykres 4.3.23. Cele zaciqgniętych przez gospodarstwa domowe kredytów i pożyczek wśród gospodarstw zadlużonych w latach 2000-2011 


\subsubsection{Aktywność gospodarstw domowych na rynku finansowym \\ Piotr Białowolski, Irena E. Kotowska}

Poprzednia edycja badania Diagnoza Spoteczna z marca 2009 r. zrealizowana została krótko po rozpoczęciu się kryzysu finansowego. W portfelach kredytowych gospodarstw domowych nie były jeszcze widoczne zmiany związane z wprowadzeniem ograniczeń kredytowych przez banki i inne instytucje finansowe. Ze względu na to, że instrumenty kredytowe zwykle objęte są kilkuletnimi umowami, a w przypadku kredytów hipotecznych umowy zawierane są na okres nawet kilkudziesięciu lat, możliwość zaobserwowania, czy i w jakim stopniu zmieniło się korzystanie gospodarstw domowych z instrumentów rynku finansowego, pojawia się dopiero w bieżącej edycji badania. Warto podkreślić, że w okresie 2009 - 2011 oprócz zmiany nastawienia samych gospodarstw domowych oraz zmiany polityki banków i pośredników finansowych do udzielania kredytów (por. Białowolski, Bieszki, Borusowski 2009) można jeszcze zaobserwować zmiany w uregulowaniu samego funkcjonowania rynku finansowego. Są one efektem wprowadzanych przez Komisję Nadzoru Finansowego regulacji, wpływających na politykę kredytową banków. Wskazują na to wyniki prowadzonych cyklicznie przez NBP badań polityki kredytowej banków (por. np. NBP 2010).

\subsubsection{Czynniki wpływające na posiadanie oszczędności i zobowiąań}

Od rozpoczęcia kryzysu finansowego udział gospodarstw domowych posiadających oszczędności zwiększył się wyraźnie (z 28 proc. w 2007 roku, 32 proc. w 2009 do 37 proc. w 2011), co w porównaniu ze stabilnym poziomem tego odsetka 23-24 proc. w rundach badania z lat 2000, 2003 i 2005 wskazuje na znaczącą zmianę.

$\mathrm{Na}$ zachowania gospodarstw domowych dotyczące oszczędzania wpływ mają czynniki związane z przebiegiem życia (fazy przebiegu życia reprezentuje wiek głowy gospodarstwa), zdolnością do generowania oszczędności (określaną głownie przez dochody) oraz relatywną pozycją gospodarstwa domowego w danym okresie związaną ze statusem na rynku pracy głowy gospodarstwa do sytuacji przeciętnej w przebiegu życia ${ }^{18}$. Te zmienne zostały uwzględnione w modelu regresji logistycznej (np. Gruszczyński, 2002). Prawdopodobieństwo posiadania oszczędności przez gospodarstwo zostało uzależnione od sytuacji materialnej gospodarstwa, wieku głowy gospodarstwa i jej statusu na rynku pracy:

$$
P\left(Y=y_{i}\right)=F^{-1}\left(x^{T} \beta\right)=\frac{e^{x^{T} \beta}}{1+e^{x^{T} \beta}}
$$

gdzie:

Y - binarna zmienna losowa przyjmująca wartości: 1 - jeśli gospodarstwo domowe ma oszczędności, 0 - jeśli gospodarstwo domowe nie ma oszczędności,

F - dystrybuanta rozkładu logistycznego;

$\mathrm{x}$ - kolumnowy wektor zmiennych objaśniających19;

$\beta$ - kolumnowy wektor parametrów.

Modele oszacowano odrębnie dla danych z rund badania 2007, 2009 i 2011, a w tabeli 4.3 .1 zamieszczono wyniki dla dwóch ostatnich edycji.

Tabela 4.3.1. Wyniki estymacji modelu regresji logistycznej dla posiadania oszczędności

\begin{tabular}{|c|c|c|c|c|c|}
\hline \multirow{2}{*}{\multicolumn{2}{|c|}{ Zmienne objaśniające }} & \multicolumn{2}{|c|}{ Badanie 2009} & \multicolumn{2}{|c|}{ Badanie 2011} \\
\hline & & \multirow{2}{*}{$\begin{array}{c}\text { B } \\
\text { (błąd standardowy) } \\
0,00086^{* * *}(0,000)\end{array}$} & \multirow{2}{*}{$\begin{array}{c}\text { Iloraz szans } \\
\operatorname{Exp}(\beta) \\
1,001\end{array}$} & \multirow{2}{*}{$\begin{array}{c}\beta \\
\text { (błąd standardowy) } \\
0,00093^{* * *}(0,000)\end{array}$} & \multirow{2}{*}{$\begin{array}{c}\begin{array}{l}\text { Iloraz szans } \\
\text { Exp }(\beta)\end{array} \\
1,001\end{array}$} \\
\hline Dochód na jednostkę konsu & cyjną & & & & \\
\hline Wiek głowy gospodarstwa & do 24 lat & $0,197(0,167)$ & 1,208 & $0,143(0,196)$ & 1,154 \\
\hline & $25-34$ & $0,264 * * *(0,068)$ & 1,302 & $-0,043(0,070)$ & 0,958 \\
\hline & $35-44$ & $0,129 * *(0,064)$ & 1,137 & $0,002(0,062)$ & 1,002 \\
\hline & $45-59$ & ref. & & ref. & \\
\hline & 60 i więcej & $0,220 * * *(0,071)$ & 1,246 & $0,317 * * *(0,069)$ & 1,373 \\
\hline \multirow{3}{*}{ Status na rynku pracy } & Pracujacy & ref. & & ref. & \\
\hline & Bezrobotni & $-0,655 * * *(0,184)$ & 0,519 & $-0,514 * * *(0,167)$ & 0,598 \\
\hline & Nieaktywni & $-0,378 * * *(0,070)$ & 0,686 & $-0,417 * * *(0,068)$ & 0,659 \\
\hline Stała & & $-1,992 * * *(0,061)$ & 0,136 & $-1,938 * * *(0,060)$ & 0,144 \\
\hline $\mathrm{N}$ & & 11472 & & 11643 & \\
\hline Miara dopasowania $\left(\mathrm{R}^{2} \mathrm{Cox}\right.$ & Snella) & 0,123 & & 0,143 & \\
\hline
\end{tabular}

Zmienne istotne przy poziomie istotności: $* * * 0,01, * * 0,05, * 0,1$

\footnotetext{
${ }^{18} \mathrm{~W}$ przypadku, gdy głowa gospodarstwa domowego nie pracuje, relatywne dochody są na ogół mniejsze niż ma to miejsce w pozostałych fazach przebiegu życia.

${ }^{19}$ Zmienne: wiek głowy gospodarstwa domowego oraz status na rynku pracy były kategorialne, co wymagało przyjęcia kategorii referencyjnych. W obu przypadkach przyjęto w tej roli grupy najliczniej reprezentowane w 2011 roku. Dla wieku głowy gospodarstwa domowego była to grupa osób w wieku 45-59 lat, zaś w przypadku statusu głowy gospodarstwa domowego na rynku pracy - kategoria pracujący.
} 
W obu okresach (2009 i 2011) dochody gospodarstwa w podobny sposób wpływały na prawdopodobieństwa posiadania oszczędności - wzrost dochodów gospodarstwa domowego o 100 PLN zwiększał szansę ${ }^{20}$ na posiadanie oszczędności o około 10 proc. Bardzo silną determinantą posiadania oszczędności w obu okresach był też status na rynku pracy głowy gospodarstwa domowego. W każdej z rund badania szansa posiadania oszczędności była około 35 - 60 proc. niższa dla gospodarstw domowych z głową w tym samym wieku i uzyskujących te same dochody wówczas, gdy głowa gospodarstwa nie pracowała w stosunku do gospodarstw z pracującą głową. Dodatkowo, na podstawie analizy parametrów modeli można stwierdzić, że bezrobocie silniej ogranicza szanse posiadania oszczędności niż bierność zawodowa.

Wyniki estymacji modelu dla 2011 roku wskazują na zmiany wpływu wieku głowy gospodarstwa na szanse posiadania oszczędności - grupy wieku 16-24 lata, 25-34 lata, 35-44 lata i 44-59 lat przestały być istotne. W przeciwieństwie do wyników z 2009 roku, w 2011 roku w każdej z tych grup wieku respondenci o analogicznym statusie na rynku pracy oraz analogicznych dochodach mieli podobną skłonność do oszczędzania.

W 2009 roku prawdopodobieństwo posiadania oszczędności w grupie 25-34 lata i 35-44 lata było istotnie większe niż w grupie referencyjnej (45-59 lat), jednak w obu okresach największe prawdopodobieństwo posiadania oszczędności obserwowane było w gospodarstwach domowych z głową gospodarstwa w wieku 60 lat i więcej. Szanse posiadania oszczędności są obecnie dla tych gospodarstw znacząco wyższe niż w pozostałych grupach a dodatkowo rosną różnice między grupą najstarszych i grupą referencyjną (szanse wyższe o 37 proc. w 2011 r. w porównaniu z niespełna 25 proc. w 2009 r.).

Przeciwnie do zmian udziału gospodarstw domowych dysponujących oszczędnościami, odsetek gospodarstw posiadających pożyczkę lub kredyt systematycznie maleje - w roku 2011 wyniósł niespełna 39 proc., co oznacza spadek względem roku 2009 o ok. 2 pp. Jest to kontynuacja tendencji obserwowanej od momentu rozpoczęcia kryzysu finansowego. Obserwowany spadek aktywności gospodarstw domowych w zaciąganiu zobowiązań występuje w sytuacji, w której polski rynek kredytowy wciąż jest stosunkowo słabo rozwinięty. W okresie kryzysu doszło jednak do znaczącego zaostrzenia polityki banków i instytucji finansowych w udzielaniu kredytów. Również Komisja Nadzoru Finansowego podjęła działania regulacyjne (głównie rekomendacja $\mathrm{T}^{21}$ ), które doprowadziły do spadku dostępności produktów kredytowych i tym samym zmniejszenia zaangażowania gospodarstw domowych na rynku kredytowym. Aby ocenić, na ile zmiany po stronie podaży kredytu wpłynęły na zmiany popytu gospodarstw domowych na kredyt, oszacowano - jak poprzednio - model regresji logistycznej. W modelu tym zmienną zależną jest posiadanie przez gospodarstwo domowe zobowiązań, zaś zmienne objaśniające są takie same jak w modelu regresji dla posiadania oszczędności, czyli prawdopodobieństwo posiadania zobowiązania jest zależne od wielkości dochodów, wieku głowy gospodarstwa domowego oraz jej statusu na rynku pracy (tabela 4. 3. 2).

Tabela 4.3.2. Wyniki estymacji modelu regresji logistycznej dla posiadania zobowiqzań

\begin{tabular}{|c|c|c|c|c|c|}
\hline \multirow{2}{*}{\multicolumn{2}{|c|}{ Zmienne objaśniające }} & \multicolumn{2}{|c|}{ Badanie 2009} & \multicolumn{2}{|c|}{ Badanie 2011} \\
\hline & & \multirow{2}{*}{$\begin{array}{c}\mathrm{B} \\
\text { (błąd standardowy) } \\
0,00008^{* * * *(0,000)}\end{array}$} & \multirow{2}{*}{$\begin{array}{c}\text { Iloraz szans } \\
\operatorname{Exp}(\beta) \\
1.00008\end{array}$} & \multirow{2}{*}{$\begin{array}{c}\beta \\
\text { (błąd standardowy) } \\
0,00005^{* * *}(0,000)\end{array}$} & \multirow{2}{*}{$\begin{array}{c}\text { Iloraz szans } \\
\operatorname{Exp}(\beta) \\
1,00005\end{array}$} \\
\hline Dochód na jednostkę konsu & cyjną & & & & \\
\hline Wiek głowy gospodarstwa & Do 24 lat & $-0,293 *(0,152)$ & 0,746 & $-0,976 * * *(0,219)$ & 0,377 \\
\hline & $25-34$ & $0,273 * * *(0,062)$ & 1,314 & $0,459 * * *(0,064)$ & 1,582 \\
\hline & $35-44$ & $0,192 * * *(0,057)$ & 1,212 & $0,495 * * *(0,056)$ & 1,641 \\
\hline & $45-59$ & ref. & & ref. & \\
\hline & 60 i więcej & $-0,770 * * *(0,063)$ & 0,463 & $-0,498 * * *(0,064)$ & 0,608 \\
\hline \multirow[t]{3}{*}{ Status na rynku pracy } & Pracujący & ref. & & ref. & \\
\hline & Bezrobotni & $-0,642 * * *(0,134)$ & 0,526 & $-0,727 * * *(0,137)$ & 0,483 \\
\hline & Nieaktywni & $-0,322 * * *(0,060)$ & 0,725 & $-0,378 * * *(0,062)$ & 0,685 \\
\hline Stała & & $-0,179 * * *(0,046)$ & 0,836 & $-0,340 * * *(0,047)$ & 0,712 \\
\hline $\mathrm{N}$ & & 11421 & & 11507 & \\
\hline Miara dopasowania $\left(\mathrm{R}^{2} \mathrm{Cox}\right.$ & Snella) & 0,068 & & 0,068 & \\
\hline
\end{tabular}

O ile prawdopodobieństwo posiadania oszczędności zależało w znaczącym stopniu od wielkości uzyskiwanych dochodów, o tyle prawdopodobieństwo posiadania kredytu zależy od tej zmiennej w stopniu bardzo niewielkim. Wpływ ten jest około dziesięciokrotnie mniejszy i wskazuje, że każde 100 PLN dodatkowego dochodu przekłada się na wzrost szansy posiadania kredytu o zaledwie 1 proc. Zgodnie z oczekiwaniami bardziej aktywne na rynku kredytowym są gospodarstwa domowe, w których głowy gospodarstw są w młodym wieku, w porównaniu do grupy referencyjnej (gospodarstwa domowe z głową w wieku 45-59 lat). Szansa posiadania zobowiązania dla grup wieku 25-34 lata i 35-44 lata jest o około 60 proc. wyższa niż w grupie referencyjnej, co może wynikać z chęci realizacji

\footnotetext{
20 W modelach regresji logistycznej współczynniki przy zmiennych wpływają na zmianę szansy, którą definiuje się jako iloraz prawdopodobieństwa sukcesu (tutaj posiadania oszczędności) do prawdopodobieństwa porażki (tutaj braku oszczędności).

21 Celem rekomendacji $\mathrm{T}$ było wprowadzenie zestawu dobrych praktyk w zakresie zarządzania ryzykiem detalicznych ekspozycji kredytowych w sektorze bankowym. Rekomendacja T zawiera szereg uregulowań w zakresie udzielania kredytów przez banki, z których najbardziej znaczące (dla gospodarstw domowych) dotyczą zwiększenia restrykcyjności w badaniu zdolności kredytowej. Regulacje w niej zawarte zdecydowanie zmniejszyły dostępność kredytu dla gospodarstw domowych.
} 
potrzeb konsumpcyjnych właściwych tej fazie przebiegu życia (zakupy dóbr trwałych, mieszkania). Gospodarstwa, w których głowy gospodarstw są w najmłodszym wieku (do 24 lat), nie są jeszcze dostatecznie wiarygodne dla instytucji finansowych, aby mogły zaciągać zobowiązania kredytowe. Dodatkowo, tej grupy dotyczy najsilniejsze ograniczenie w zaciąganiu zobowiązań względem sytuacji przedkryzysowej. Dostępność kredytu, mierzona szansą jego posiadania, była o ponad 60 proc. niższa niż w grupie referencyjnej. W 2009 roku szansa ta była zaledwie o 25 proc. mniejsza. Dla gospodarstw osób starszych (głowa gospodarstwa ma 60 i więcej lat) prawdopodobieństwo posiadania zobowiązania kredytowego o około 40 proc. niższe niż w grupie referencyjnej. Można to przypisać dwóm zasadniczym czynnikom. Po pierwsze, po osiaggnięciu pewnego wieku najprawdopodobniej większość potrzeb, tradycyjnie finansowanych kredytem, została już zaspokojona. Po drugie, należy pamiętać, że na polskim rynku kredytowym ta część gospodarstw domowych, których głowy są dziś w wieku powyżej 44 lat, rozpoczęła aktywność zawodową (i tym samym pojawiły się u nich największe potrzeby pożyczkowe) w okresie, gdy rynek kredytowy był jeszcze na tyle słabo rozwinięty, że nie oferował produktów adekwatnych do potrzeb tej grupy.

Podobnie jak w przypadku posiadania oszczędności, zatrudnienie sprzyja podejmowaniu zobowiązań kredytowych. Prawidłowość ta dotyczy zarówno roku 2009 jak i 2011. Jest to związane z czynnikami oddziałującymi na gospodarstwo domowe zarówno po stronie podażowej, jak i popytowej. Z jednej strony mniejsze dochody nie skłaniają do dokonywania poważnych zakupów, które często są finansowane kredytem. Z drugiej strony, gospodarstwa domowe, których głowa nie posiada stałego zatrudnienia, są znacząco mniej wiarygodne dla instytucji finansowych i tym samym maja znacznie mniejsze szanse uzyskania kredytu. Dodatkowo, bezrobocie głowy gospodarstwa domowego silniej zmniejsza prawdopodobieństwo posiadania zobowiązań w porównaniu do gospodarstw domowych, w których głowa gospodarstwa jest bierna zawodowo. Fakt bycia bezrobotnym jest bardzo negatywnym sygnałem dla instytucji rynku finansowego i często zamyka drogę gospodarstwom domowym do korzystania z produktów kredytowych. Natomiast w przypadku gospodarstw domowych, w których głowy są bierne zawodowo, dochody częstokroć uzyskiwane są ze świadczeń socjalnych. Świadczenia te zaś przyznawane są na dłuższy okres lub nawet na stałe (emerytura), co wpływa na zwiększenie zdolności kredytowej gospodarstw domowych i pozwala im częściej (niż bezrobotnym) korzystać z kredytu.

\subsubsection{Wielkość oszczędności polskich gospodarstw domowych wedtug form oszczędzania}

Tempo wzrostu dochodów gospodarstw domowych w Polsce w latach 2009-2011 znacząco zmalało - w latach 2007 - 2009 wzrost dochodów ekwiwalentnych sięgnął prawie 22 proc. po skorygowaniu o wielkość inflacji, zaś w okresie 2009 - 2011 wzrost wyniósł zaledwie 3,4 proc. Jednak nawet ten niewielki przyrost dochodów realnych znalazł odbicie we wzroście odsetka gospodarstw domowych z oszczędnościami. Biorąc jednak pod uwagę fakt, że gospodarstwa domowe przyzwyczaiły się do szybko rosnącego poziomu życia, poddano analizie przeciętną wielkość oszczędności. Wykorzystano przy tym następujące podejście analityczne. Uznano, ze poziom oszczędności w relacji do dochodu może zostać opisany rozkładem prawostronnie skośnym dla zmiennej przyjmującej wartości nieujemne. Sprawdzono hipotezę, że wielkość oszczędności w relacji do dochodu można opisać rozkładem lognormalnym ${ }^{22}$. Na podstawie oszacowanych parametrów rozkładu log-normalnego obliczono przeciętną wielkość oszczędności w relacji do dochodu w polskich gospodarstwach domowych korzystając ze wzoru

$$
E(X)=e^{\mu+\frac{\sigma^{2}}{2}}
$$

gdzie ${ }^{\mu}$ oznacza średnią rozkładu normalnego, a $\sigma$ jego odchylenie standardowe. Wyniki obliczeń przedstawiono w tabeli 4.3.3.

Tabela 4.3.3. Przeciętna wielkość oszczędności w latach 2007, 2009 i 2011

\begin{tabular}{llll}
\cline { 2 - 3 } & 2007 & 2009 & 2011 \\
\hline Średnia wielkość oszczędności (w relacji do miesięcznych dochodów) & $\sim 4,51$ & $\sim 4,86$ & $\sim 4,72$ \\
\hline
\end{tabular}

Przeciętna wielkość oszczędności w relacji do dochodu w polskich gospodarstwach domowych wzrosła w latach 2007 - 2009 z 4,51 krotności miesięcznych dochodów w roku 2007 do 4,86 krotności miesięcznych dochodów w 2009 roku. W okresie 2009 - 2011 przeciętna wielkość oszczędności spadła nieznacznie z 4,86 krotności miesięcznych dochodów do 4,72.

Struktura gospodarstw domowych gromadzących oszczędności według ich formy przedstawiona została na wykresie 4.3.20. Tutaj zajmiemy się analizą wielkości zgromadzonych oszczędności w zależności od sposobu ich gromadzenia, co pokazuje sposób zarządzania oszczędnościami przez gospodarstwa domowe. Gospodarstwa domowe mogą być zorientowane na korzystanie $\mathrm{z}$ instrumentów finansowych, które (1) przynoszą przeciętnie większe zyski lub (2) pozwalają na ograniczanie ryzyka - dobrze pojętego w przypadku oszczędzania w postaci lokat oraz źle pojętego, w przypadku gromadzenia oszczędności w formie gotówki. W związku z faktem, że gospodarstwa domowe podawały jedynie zagregowaną wielkość oszczędności, bez rozbijania tej wielkości na

\footnotetext{
${ }^{22}$ Obliczona na podstawie danych wartość statystyki $\lambda$-Kołmogorowa wyniosła dla roku $2007-0,543$, dla 2009 roku - 0,630, a dla 2011 roku 0,256 nie dając podstaw do odrzucenia hipotezy, która dotyczyła zgodności rozkładu poziomu oszczędności w relacji do dochodu z rozkładem log-normalnym.
} 
konkretne formy gromadzenia oszczędności do analiz wykorzystano model wielomianowej regresji logistycznej. W modelu tym prawdopodobieństwo przynależności respondenta o zestawie cech $\mathrm{X}$ do j-tej kategorii zmiennej $\mathrm{Y}$ można opisać za pomocą formuły (np. Gruszczyński, 2002): $\quad P(Y=j \mid X)=\frac{e^{X \beta_{j}}}{\sum_{l=1}^{J} e^{X \beta_{l}}}$

$$
P\left(Y=y_{j} / X\right)=\frac{e^{x^{T} \beta_{j}}}{\sum_{j=1}^{m} e^{x^{T} \beta_{j}}}
$$

gdzie:

Y - zmienna losowa przyjmująca m kategorii opisująca wielkość posiadanych oszczędności wyrażoną jako krotność dochodów,

$\mathrm{X}^{\mathrm{T}}$ - kolumnowy wektor zmiennych objaśniających;

$\beta$ - kolumnowy wektor parametrów, przy czym $\beta$ wynosi zero dla kategorii referencyjnej (w analizowanym modelu za kategorię referencyjną przyjęto zadłużenie mniejsze od jednokrotności miesięcznych dochodów)

Następnie obliczono prawdopodobieństwa warunkowe przynależności gospodarstwa domowego do danej kategorii wielkości oszczędności pod warunkiem posiadania oszczędności tylko w jednej formie. Obliczone na podstawie rozkładów prawdopodobieństw warunkowych przeciętne wielkości oszczędności przedstawia tabela 4.3.4.

Tabela 4.3.4. Przeciętna wielkość oszczędności w 2009 i 2011 roku w gospodarstwach domowych w zależności od sposobu oszczędzania

\begin{tabular}{lcc}
\hline \multicolumn{1}{c}{ Forma oszczędzania } & $\begin{array}{c}\text { Przeciętna wielkość oszczędności } \\
\text { (krotność dochodu gospodarstwa) w 2009 }\end{array}$ & $\begin{array}{c}\text { Przeciętna wielkość oszczędności } \\
\text { (krotność dochodu gospodarstwa) w 2011 }\end{array}$ \\
\hline lokaty w bankach w złotych & $\sim 4,2$ & $\sim 4,5$ \\
lokaty w bankach w walutach obcych & $\sim 3,9$ & $\sim 3,1$ \\
w obligacjach & $\sim 4,7$ & $\sim 3,3$ \\
w funduszach inwestycyjnych & $\sim 3,9$ & $\sim 4,6$ \\
Indywidualne Konto Emerytalne & $\sim 2,0$ & $\sim 2,5$ \\
w papierach wartościowych & $\sim 5,0$ & $\sim 3,1$ \\
notowanych na giełdzie & & $\sim 5,4$ \\
udziały oraz akcje w prywatnych & $\sim 4,3$ & $\sim 4,5$ \\
spółkach akcyjnych & $\sim 4,0$ & $\sim 2,2$ \\
lokaty w nieruchomościach & $\sim 3,4$ & $\sim 2,4$ \\
lokaty w innych niż nieruchomości & $\sim 2,2$ & $\sim 2,5$ \\
dobrach materialnych & nie występowało & $\sim 2,6$ \\
w gotówce & $\sim 2,6$ & \\
w polisie ubezpieczeniowej & & \\
w innej formie & & \\
\hline
\end{tabular}

Największe oszczędności w relacji do dochodu posiadają gospodarstwa domowe gromadzące swoje oszczędności w formie udziałów oraz akcji w prywatnych spółkach akcyjnych. Oszczędności zgromadzone w tej formie w roku 2011 sięgają przeciętnie 5,4-krotności miesięcznych dochodów w gospodarstwie domowym. Również wysokie (wynoszące 4,6 krotności dochodów) są oszczędności zgromadzone w postaci jednostek funduszy inwestycyjnych. Niewiele mniejsze są oszczędności gospodarstw domowych w formie lokat złotowych, które stanowią najczęstszą formę oszczędzania. Wielkość oszczędności w tej formie w gospodarstwach domowych posiadających oszczędności tylko w tej formie sięga 4,5 krotności dochodów. W porównaniu do 2009 roku spadła znacząco wielkość oszczędności gromadzonych w formie akcji i obligacji. W przypadku akcji wydaje się, że duże znaczenie dla tej zmiany miało spopularyzowanie formy akcjonariatu obywatelskiego, który przez bardzo duże prywatyzacje (głównie PZU i GPW) spowodował, że zwiększył się odsetek gospodarstw domowych korzystających $\mathrm{z}$ tej formy oszczędzania. Trzeba jednak wziąć pod uwagę, że możliwość nabycia akcji dla inwestorów indywidualnych w ofertach akcjonariatu obywatelskiego była bardzo ograniczona, co wpłynęło na zmniejszenie przeciętnej wielkości oszczędności gromadzonych w tej formie. W odniesieniu do obligacji wydaje się, że obecnie ten instrument jest zdecydowanie mniej popularny ze względu na zmniejszenie liczby ofert obligacji dla gospodarstw domowych, a także zmniejszenie promocji tego instrumentu ze strony rządu. Zatem dla obligacji odnotowano zarówno mniejszy odsetek gospodarstw domowych korzystających z tej formy oszczędności, jak i mniejszą przeciętną wielkość środków zgromadzonych w tej formie. Pozytywnym sygnałem jest, że pomimo występowania znaczącej grupy gospodarstw domowych, które gromadzą oszczędności w formie gotówki, w ten sposób lokowana jest bardzo niewielka część środków, a ich wielkość wynosi niewiele więcej niż dwukrotność miesięcznych dochodów. Również niewielkie są oszczędności zgromadzone w formie indywidualnego konta emerytalnego (IKE). Wprawdzie przeciętna wielkość oszczędności zgromadzonych w tej formie wzrosła względem 2009 roku (z 2,0 do 2,5 krotności dochodów), to w znacznej mierze wzrost ten wynika ze zmniejszenia liczby gospodarstw domowych, które posiadają Indywidualne Konto Emerytalne (por. wykres 4.3.20) . Oznacza to, że część gospodarstw domowych swoje IKE zamknęła lub zaniechała z odkładania funduszy w tej formie. W znacznej mierze związane to jest z niewielkimi zachętami (w formie ulg podatkowych) dla oszczędzających w ten sposób. Z 
drugiej strony można przypuszczać, że gospodarstwa domowe w Polsce nie są chętne długofalowemu oszczędzaniu. $^{23}$

W punkcie 4.3.2 poddano analizie cele oszczędzania. Strukturę gospodarstw domowych gromadzących oszczędności według ich formy przedstawiono na wykresie 4.3.21. Dokonano także analizy przeciętnej wielkości oszczędności w zależności od celu oszczędzania. Wielkości przedstawione w tabeli pokazują oczekiwaną przeciętną wielkość oszczędności dla gospodarstwa domowego posiadającego oszczędności tylko na jeden cel ${ }^{24}$.

W roku 2011 największą przeciętnie wielkość oszczędności w relacji do dochodów zgromadziły gospodarstwa domowe, które oszczędzają na zakup mieszkania lub budowę domu. W relacji do miesięcznych dochodów wielkość zgromadzonych na ten cel oszczędności sięga ponad ośmiokrotności przeciętnych dochodów. Dodatkowo widoczny jest wzrost przeciętnej wielkości zgromadzonych oszczędności na ten cel względem 2009 roku. Jest to związane z faktem, że od momentu rozpoczęcia kryzysu finansowego trudniej jest dostać kredyt na zakup mieszkania bez zgromadzenia znaczącego wkładu własnego. Wzrost z 6,2 do 8,1 krotności dochodów należy w tym przypadku traktować również jako pozytywny sygnał dla rynku mieszkaniowego, który ma szansę rozwijać się dzięki coraz większemu zaangażowaniu oszczędności gospodarstw domowych.

Tabela 4.3.5. Przeciętna wielkość oszczędności w 2009 i 2011 roku w gospodarstwach domowych w zależności od celu ich gromadzenia

\begin{tabular}{lcc}
\hline \multicolumn{1}{c}{ Cel gromadzenia oszczędności } & $\begin{array}{c}\text { Przeciętna wielkość oszczędności } \\
\text { (krotność dochodów gospodarstwa) } \\
\text { w 2009 roku }\end{array}$ & $\begin{array}{c}\text { Przeciętna wielkość oszczędności } \\
\text { (krotność dochodów gospodarstwa) } \\
\text { w 2011 roku }\end{array}$ \\
\hline rezerwa na bieżące wydatki konsumpcyjne & $\sim 2,3$ & $\sim 2,3$ \\
(np. żywność, odzież i ubranie) & $\sim 2,1$ & $\sim 2,3$ \\
stałe opłaty (np. mieszkaniowe) & $\sim 4,0$ & $\sim 4,3$ \\
zakup dóbr trwałego użytku & $\sim 6,2$ & $\sim 8,1$ \\
zakup domu, zakup mieszkania, wkład do & $\sim 3,5$ & $\sim 3,3$ \\
spółdzielni mieszkaniowej & $\sim 2,6$ & $\sim 2,9$ \\
remont domu, mieszkania & $\sim 3,6$ & $\sim 4,5$ \\
leczenie & $\sim 3,2$ & $\sim 3,9$ \\
rehabilitacja & $\sim 3,5$ & $\sim 3,5$ \\
wypoczynek & $\sim 4,9$ & $\sim 4,3$ \\
rezerwa na sytuacje losowe & $\sim 7,2$ & $\sim 6,5$ \\
zabezpieczenie przyszłości dzieci & $\sim 4,1$ & $\sim 4,0$ \\
zabezpieczenie na starość & $\sim 3,2$ & $\sim 4,2$ \\
na inne cele & & \\
bez specjalnego przeznaczenia & & \\
\hline
\end{tabular}

Na drugim miejscu pod względem wielkości zgromadzonych środków plasują się oszczędności mające na celu zabezpieczenie starości, ich przeciętna wielkość spadła jednak względem 2009 roku (z 7,2 krotności miesięcznych dochodów do 6,5 krotności). Pod względem wartości najmniejsze oszczędności gromadzą gospodarstwa domowe, które oszczędzają celem stworzenia rezerwy na bieżące wydatki i stałe opłaty. Oszczędności, jeżeli zostały zgromadzone na któryś z tych celów, nie przekraczają znacząco dwukrotności miesięcznych dochodów.

\subsubsection{Wielkość zobowiqzań gospodarstw domowych wedtug źródła pochodzenia i celu}

Dla gospodarstw domowych posiadających zobowiązania oszacowano wielkości posiadanego zadłużenia w relacji do dochodu i jego zmiany w czasie. Stosując podobne podejście analityczne jak dla oszczędności przyjęto również, że wielkość posiadanych zobowiązań w zależności od dochodu może zostać przybliżona rozkładem lognormalnym. ${ }^{25}$ Wyniki szacunku przeciętnej wielkości zobowiązania przedstawiono w tabeli 4.3.6.

Tabela 4.3.6. Przeciętna wielkość zadtużenia w latach 2007, 2009 i 2011

\begin{tabular}{lccc}
\cline { 2 - 3 } & 2007 & 2009 & 2011 \\
\hline Średnia wielkość zadłużenia (w relacji do miesięcznych dochodów) & $\sim 6,61$ & $\sim 9,58$ & $\sim 15,1$ \\
\hline
\end{tabular}

Przeciętne wielkości zobowiązań gospodarstw domowych są znacząco większe niż przeciętne wielkości oszczędności w relacji do dochodu we wszystkich porównywanych latach. Dodatkowo następuje szybki wzrost zadłużenia gospodarstw domowych przy jednoczesnej stabilizacji przeciętnej wielkości oszczędności. Oznacza to

\footnotetext{
${ }^{23}$ Związane to jest po części z oczekiwaną ścieżką przyszłych dochodów w przebiegu życia gospodarstwa domowego. W przypadku gospodarki relatywnie słabo rozwiniętej jest bardzo prawdopodobne, że dochody gospodarstw domowych będą dość szybko zwiększać się w kolejnych latach. W takiej sytuacji gromadzenie oszczędności zwłaszcza długookresowych jest mało racjonalne.

${ }^{24}$ Przeciętne wielkości oszczędności obliczono na podstawie sprawdzenia zgodności rozkładu oczekiwanych odpowiedzi na pytanie o wielkość oszczędności z rozkładem log-normalnym.

${ }^{25}$ Obliczona wartość statystyki testującej $\lambda$-Kołmogorowa wyniosła dla roku 2007 - 0,178, dla 2009 roku - 0,245, a dla 2011 roku - 0,184 co nie daje podstaw do odrzucenia hipotezy mówiącej o zgodności rozkładu wielkości zobowiązań w relacji do dochodu z rozkładem log-normalnym dla żadnego z okresów.
} 
coraz większą dysproporcję między poziomem oszczędności i zadłużeniem w polskich gospodarstwach domowych. W 2007 roku przeciętna wielkość zadłużenia równa była dochodom uzyskiwanym przez gospodarstwo w ciągu 6,6 miesiąca. W roku 2009 wzrosła ona o wielkość równą kwartalnym dochodom gospodarstwa, zaś w 2011 roku podniosła się o ponad pięciokrotność dochodów gospodarstwa domowego, sięgając ostatecznie 15,1-krotności miesięcznych dochodów gospodarstwa domowego.

Systematycznie obserwowany jest również wzrost zróżnicowania wielkości zadłużenia gospodarstw domowych mierzony odchyleniem standardowym wielkości zadłużenia w relacji do dochodu ${ }^{26}$. Wynik ten jest zgodny z danymi statystycznymi dotyczącymi wielkości zadłużenia Polaków w ostatnim okresie. Według danych Narodowego Banku Polskiego w ostatnich latach głównym czynnikiem wzrostu polskiego rynku kredytowego jest wzrost zadłużenia gospodarstw domowych przede wszystkim z tytułu kredytów mieszkaniowych. Według danych NBP kredyty konsumpcyjne rosną w ostatnim okresie w tempie poniżej inflacji. Co więcej wzrost zadłużenia $\mathrm{z}$ tytułu kredytów mieszkaniowych nie jest częstokroć wynikiem zaciagania nowych kredytów, lecz wynika ze wzrostu wartości kredytów denominowanych w walutach obcych (głównie franku szwajcarskim). Jakkolwiek zakup nieruchomości na kredyt dotyczy wciąż stosunkowo niewielkiej grupy gospodarstw domowych, to związany jest $\mathrm{z}$ zaciągnięciem zobowiązania o znaczącej wielkości - często równego nawet kilkuletnim dochodom całego gospodarstwa.

Gospodarstwa domowe dysponują trzema opcjami wyboru źródła pozyskiwania finansowania. Są to: bank, inna instytucja finansowa oraz osoby prywatne. Struktura gospodarstw domowych posiadających zobowiązania według źródła ich pozyskania przedstawiona została na wykresie 4.3.23. W ciagu ostatnich dwóch lat, wśród gospodarstw domowych posiadających zobowiązanie, nieznacznemu zmniejszeniu uległy odsetki gospodarstw domowych, które zaciągnęły zobowiązania w banku i innych instytucjach finansowych, wzrósł zaś odsetek gospodarstw domowych finansujących swoje wydatki za pomocą pożyczek zaciąganych u osób prywatnych. Może to wynikać zarówno ze zmniejszenia zainteresowania ofertą kredytową instytucji pośrednictwa finansowego, jak i zmniejszenia dostępności kredytów - szczególnie konsumpcyjnych - oferowanych przez sektor bankowy. Dodatkowo zmniejsza się dostępność źródeł finansowania takich jak pożyczki w zakładzie pracy, które stanowiły nierynkową konkurencję dla pożyczek zaciąganych w bankach. Pomimo że polskie gospodarstwa domowe przekonują się powoli, że finansowanie wydatków za pomocą zobowiązań zaciąganych u osób prywatnych (głównie rodziny) wiąże się z poważnym ryzykiem i wprowadza napięcie w relacjach rodzinnych, to niestety znaczące odcięcie od rynkowych źródeł finansowania zmusza je do sięgnięcia do tych archaicznych metod finansowania nadwyżkowej konsumpcji.

W celu oceny wielkości wpływu źródła, z którego pochodzi zobowiązanie, na wielkość tego zobowiązania oszacowano model wielomianowej regresji logistycznej. Na podstawie rozkładów warunkowych obliczono przeciętne wielkości posiadanych zobowiązań dla zadłużenia posiadanego $\mathrm{w}$ banku, $\mathrm{w}$ innych instytucjach oraz $\mathrm{u}$ osób prywatnych. Przedstawiono je w tabeli 4.3.7.

Tabela 4.3.7. Przeciętna wielkość zobowiqzania w 2009 i 2011 roku w gospodarstwach domowych w zależności od jego źródta.

\begin{tabular}{llll}
\hline \multicolumn{1}{c}{ Źródło zobowiązania } & \multicolumn{2}{c}{ Zobowiązania zaciągnięte } \\
\cline { 2 - 4 } & W bankach & W innych instytucjach & U osób prywatnych \\
\hline $\begin{array}{l}\text { Przeciętna wielkość zobowiązań (wyrażona w } \\
\text { krotności dochodów) w 2009 roku }\end{array}$ & $\sim 10,7$ & $\sim 3,0$ & $\sim 3,9$ \\
$\begin{array}{l}\text { Przeciętna wielkość zobowiązań (wyrażona w } \\
\text { krotności dochodów) w 2011 roku }\end{array}$ & $\sim 16,7$ & $\sim 4,6$ & $\sim 4,8$ \\
\hline
\end{tabular}

W gospodarstwach domowych, które posiadają zobowiązania, największa przeciętna ich wysokość dotyczy zobowiązań zaciągniętych w bankach - przeciętna wielkość tego zadłużenia równa jest ponad szesnastokrotności jego dochodów. Wielkość zobowiązania zaciąnniętego w innych instytucjach lub u osób prywatnych wynosi poniżej pięciokrotności dochodów miesięcznych. Tę znaczącą dysproporcję można częściowo przypisać temu, że jedynie banki udzielają kredytów o znacznej wartości, w tym głównie kredytów hipotecznych. Ponadto, banki są w praktyce jedynymi instytucjami kredytującymi indywidualną działalność gospodarczą. W przypadku innych instytucji finansowych często możliwe jest jedynie zaciągnięcie zobowiązania na sfinansowanie bieżącej konsumpcji. Zobowiązania wobec banków $\mathrm{i}$ innych instytucji znacząco wzrosły w ciągu ostatnich dwóch lat. W przypadku banków wzrost ten spowodowany został najprawdopodobniej przesunięciem akcentów polityki sektora bankowego. Zmniejszyła się chęć finansowania przez banki konsumpcji, co jednoznacznie zwiększyło nacisk na finansowanie zakupu mieszkań. Dodatkowo, wzrosła przeciętna wartość kredytów (i to bardzo znacząco) denominowanych w walutach obcych, co doprowadziło do znaczącego wzrostu zadłużenia gospodarstw domowych, nawet bez konieczności zaciągania dodatkowych zobowiązań. W odniesieniu do innych instytucji wzrost przeciętnego zadłużenia może być pochodną polityki banków. Zwiększenie wymagań finansowych wobec klientów skutkuje przeniesieniem popytu na kredyt do sektora innych instytucji finansowych, które wciąż stosują mniejsze restrykcje dla gospodarstw domowych, jednak żądają zazwyczaj wyższego wynagrodzenia w postaci wyższych stóp procentowych.

\footnotetext{
${ }^{26}$ W latach 2007 - 2011 zaobserwowano ponad dwukrotny wzrost odchylenia standardowego wielkości zadłużenia gospodarstw domowych.
} 
Wielkość zaciagniętych zobowiązań u rodziny i znajomych jest zdecydowanie mniejsza niż zobowiązania w bankach, jednak większa niż poziom zobowiązań gospodarstw domowych zaciągniętych w innych instytucjach finansowych. Oznacza to, że oferta instytucji pośrednictwa finansowego (będąca bazą pożyczkową dla gospodarstw domowych o niższej wiarygodności kredytowej) nie jest jeszcze na tyle konkurencyjna, aby zastępować pożyczki grzecznościowe, które nie wymagają spełnienia wielu formalności oraz są zwykle oprocentowane bardzo nisko lub wcale. Ponadto w Polsce wciąż jeszcze jest spora niechęć do instytucji finansowych w ogóle, co znacząco zacieśnia krąg ich potencjalnych klientów. Warto jednak podkreślić, że również w tym przypadku w roku 2011 odnotowano znaczący wzrost przeciętnego zadłużenia z tytułu pożyczek zaciągniętych przez gospodarstwa domowe u osób prywatnych w stosunku do roku 2009. Wynika to najpewniej ze zmniejszenia dostępności kredytów dla gospodarstw domowych o niższej wiarygodności. Gospodarstwa te, wpadając w pułapkę zadłużenia, starają się szukać alternatywnych sposobów finansowania konsumpcji zaciągając zobowiązania u rodziny bądź znajomych.

W punkcie 4.3.2 przedstawiono strukture gospodarstw domowych zaciągających zobowiązania na wybrane cele. Rozkład gospodarstw domowych zaciągających zobowiązania według ich celu przedstawiony został na wykresie 4.3.24. Tutaj, w analogiczny sposób, jak w przypadku źródeł finansowania zobowiązań, prezentujemy analizę przeciętnej wielkości zobowiązania w zależności od celu. ${ }^{27}$ Wielkości przedstawione $\mathrm{w}$ tabeli 4.3.8. pokazują oczekiwaną przeciętną wielkość zobowiązania dla gospodarstwa domowego posiadającego kredyt/pożyczkę tylko na jeden cel.

Tabela 4.3.8. Przeciętna wielkość zobowiqzań w 2009 i 2011 roku w gospodarstwach domowych w zależności od celu ich zaciagnięcia

\begin{tabular}{|c|c|c|}
\hline Cel zaciągania zobowiązania & $\begin{array}{c}\text { Przeciętna wielkość zobowiązań } \\
\text { (krotność dochodów gospodarstwa) } \\
\text { w } 2009 \text { roku }\end{array}$ & $\begin{array}{c}\text { Przeciettna wielkość zobowiązań } \\
\text { (krotność dochodów gospodarstwa) } \\
\text { w } 2011 \text { roku } \\
\end{array}$ \\
\hline $\begin{array}{l}\text { rezerwa na bieżące wydatki konsumpcyjne } \\
\text { (np. żywność, odzież, obuwie) }\end{array}$ & $\sim 4,3$ & $\sim 3,9$ \\
\hline stałe opłaty (np. mieszkaniowe) & $\sim 4,2$ & $\sim 6,2$ \\
\hline zakup dóbr trwałego użytku & $\sim 4,0$ & $\sim 5,6$ \\
\hline $\begin{array}{l}\text { zakup domu, zakup mieszkania, wkład do } \\
\text { spółdzielni mieszkaniowej* }\end{array}$ & ---- & ---- \\
\hline remont domu, mieszkania & $\sim 6,3$ & $\sim 8,2$ \\
\hline leczenie & $\sim 3,8$ & $\sim 4,0$ \\
\hline $\begin{array}{l}\text { zakup, dzierżawa narzędzi do pracy } \\
\text { (maszyny, wynajem lokalu itd.) }\end{array}$ & $\sim 7,1$ & $\sim 7,6$ \\
\hline wypoczynek & $\sim 4,1$ & $\sim 4,3$ \\
\hline zakup papierów wartościowych** & ---- & ---- \\
\hline spłata wcześniejszych długów & $\sim 10,9$ & $\sim 16,4$ \\
\hline rozwój własnej działalności gospodarczej & $\sim 14,5$ & $\sim 11,7$ \\
\hline kształcenie & $\sim 5,4$ & $\sim 4,0$ \\
\hline na inne cele & $\sim 5,9$ & $\sim 5,8$ \\
\hline
\end{tabular}

* oszacowanie przeciętnego zadłużenia na zakup mieszkania jest bardzo utrudnione, gdyż większość gospodarstw domowych posiadających tego typu zadłużenie deklaruje, że przekracza ono wartość rocznych dochodów. Z oszacowanych modeli wielomianowej regresji logistycznej wynika, że w 2009 roku w grupie gospodarstw domowych zadłużonych tylko w celu zakupu mieszkania aż 60\% miało zadłużenie przekraczające wysokość rocznych dochodów gospodarstwa, a w 2011 roku odsetek ten wyniósł $65 \%$.

** informacje o przeciętnym zadłużeniu na zakup papierów wartościowych nie były szacowane ze względu na bardzo niewielką liczbę respondentów posiadających tego typu zadłużenie - odpowiednio 10 i 6 osób w latach 2009 i 2011.

W roku 2011 największą przeciętnie wielkość zobowiązań w relacji do dochodów mają niewątpliwie gospodarstwa domowe, które zadłużyły się na zakup mieszkania. W 2009 roku gospodarstwa domowe zadłużające się jedynie w tym celu w ponad 60 proc. przypadków posiadały zadłużenie większe niż ich roczne dochody. W roku 2011 odsetek ten wyniósł ok. 65 proc. Na drugim miejscu, pod względem wielkości zaciaggniętego zobowiązania w relacji do dochodów, znajdują się zobowiązania zaciągnięte w celu spłaty wcześniejszych zobowiązań. Jest to bardzo niepokojące zjawisko, szczególnie biorąc pod uwagę bardzo silny wzrost przeciętnej wielkości zadłużenia na ten cel - z niespełna jedenastokrotności miesięcznych dochodów w 2009 roku do ponad szesnastokrotności w roku 2011. Dodatkowo, liczba gospodarstw domowych posiadających zobowiązania zaciągnięte w celu spłaty wcześniejszych zobowiązań wzrosła w roku 2011 w stosunku do roku 2009. Oznacza to, że, mimo utrzymywania się dodatniego tempa wzrostu gospodarczego, grupa gospodarstw domowych mających problemy ze spłatą zobowiązań systematycznie rośnie. Na trzecim miejscu pod względem przeciętnej wartości zobowiązania uplasowały się kredyty/pożyczki zaciągane celem rozwoju własnej działalności gospodarczej. Przeciętna wielkość zobowiązania na ten cel sięga około rocznych dochodów gospodarstwa domowego. Jednak i w tym obszarze odnotowano znaczące zaostrzenie polityki kredytowej banków i innych instytucji finansowych, co przełożyło się na spadek finansowania działalności gospodarczej gospodarstw domowych w Polsce. Stosunkowo niewielkie są przeciętne wielkości zobowiązań zaciągniętych na sfinansowanie potrzeb konsumpcyjnych, bądź bieżących.

\footnotetext{
${ }^{27}$ Przeciętne wielkości tych zobowiązań obliczono na podstawie sprawdzenia zgodności - z rozkładem log-normalnym - rozkładu oczekiwanych odpowiedzi na pytanie o wielkość zobowiązań w zależności od celu posiadanych oszczędności.
} 


\subsubsection{Podsumowanie}

W ostatnich dwóch latach doszło do znaczących zmian w korzystaniu przez gospodarstwa domowe z rynku finansowego. $\mathrm{Z}$ jednej strony spadek dynamiki dochodów gospodarstw domowych przełożył się na zachwianie równowagi między przeciętną wielkością oszczędności i przeciętną wielkością zobowiązań. Zgodnie z tezą ekonomii behawioralnej można zakładać, że oczekiwania szybkiego wzrostu dochodów przekładają się na tworzenie nawyków konsumpcyjnych, co przyczynia się do chęci podtrzymania bieżącej dynamiki konsumpcji (por. Brown 2008). Na skutek tego zaobserwowano zwiększenie przeciętnej wielkości zadłużenia w gospodarstwach posiadających kredyty/pożyczki oraz spadek przeciętnej wielkości oszczędności w gospodarstwach domowych posiadających oszczędności. Z drugiej strony, utrzymanie dodatniej dynamiki dochodów gospodarstw domowych, zaowocowało niewielkim wzrostem zamożności gospodarstw domowych i w konsekwencji przełożyło się na wzrost odsetka gospodarstw, które chcą i mogą pozwolić sobie na posiadanie oszczędności. Ten wzrost zamożności oraz zaostrzenie polityki kredytowej banków miało również przełożenie na spadek popytu na kredyty o niewielkiej wartości, a w konsekwencji spadek odsetka gospodarstw domowych posiadających zadłużenie. 


\subsection{Warunki mieszkaniowe}

\subsubsection{Sytuacja w 2011 r. i jej zmiana w ostatnich czterech latach Tomasz Panek}

Ponad 4 proc. badanych gospodarstw domowych nie zamieszkiwało w marcu 2011 r. samodzielnie. Odsetek ten nie zmienił się w sposób istotny w okresie marzec 2007-marzec $2011^{28}$. Natomiast w ostatnich dwóch latach spadł o ponad 2 p.p. ${ }^{29}$.

Najczęściej gospodarstwa niezamieszkujące samodzielnie występowały w grupie gospodarstw domowych utrzymujących się z niezarobkowych źródeł oraz rolników (odpowiednio ponad 7 proc. i ponad 6 proc. gospodarstw). W latach 2009-2011 we wszystkich grupach społeczno-ekonomicznych nastapił spadek odsetka gospodarstw domowych niezamieszkujących samodzielnie, w tym najsilniej w gospodarstwach domowych emerytów oraz pracujących na własny rachunek (odpowiednio o prawie 4 i ponad 3 p.p).

Brak samodzielności mieszkań w przekroju typu gospodarstwa najczęściej charakteryzował gospodarstwa wielorodzinne. W tej grupie było prawie 6 proc. takich gospodarstw. We wszystkich typach gospodarstw domowych nastąpił spadek częstotliwości samodzielnego zamieszkiwania w marcu 2011 r. w stosunku do marca 2009 r., przy czym najsilniejszy w grupach gospodarstw małżeństw bez dzieci oraz nierodzinnych jednoosobowych (o odpowiednio o prawie 4 i ponad 3 p.p).

$\mathrm{W}$ grupie gospodarstw domowych bez bezrobotnych ponad 4 proc. $\mathrm{z}$ nich nie zamieszkiwało samodzielnie $\mathrm{W}$ 2011 r., podczas gdy ponad 3 proc. w grupie gospodarstw domowych z bezrobotnymi. W ostatnich dwóch latach znacząco przy tym spadł odsetek gospodarstw domowych bez bezrobotnych zamieszkujących niesamodzielnie (o prawie 3 p.p).

Gospodarstwa niezamieszkujące samodzielnie spotkać można było najczęściej na wsi (ponad 5 proc.). Województwem o największym odsetku gospodarstw domowych niezamieszkujących samodzielnie było lubelskie (ponad 11 proc.). Znaczący spadek odsetka gospodarstw domowych niezamieszkujących samodzielnie obserwujemy w dwóch ostatnich latach we wszystkich wyróżnionych w badaniu wielkościach miejscowości zamieszkania, przy czym największy w średniej wielkości miastach, liczących 100-200 tys. mieszkańców oraz na wsi (po prawie 4 p.p). Województwami, w których obserwujemy najbardziej znaczący wzrost samodzielności zamieszkiwania w okresie marzec 2009-marzec 2011 były województwa opolskie i mazowieckie (odpowiednio o ponad 6 i ponad 4 p.p).

Średnia powierzchnia użytkowa mieszkania na 1 osobę w badanych gospodarstwach wynosiła w marcu $2009 \mathrm{r}$. prawie $34 \mathrm{~m}^{2}$. W marcu $2011 \mathrm{r}$. w stosunku do sytuacji z marca $2007 \mathrm{r}$. wzrosła ona o $4 \mathrm{~m}^{2}$. W ostatnich 2 latach wzrosła natomiast o około $2,5 \mathrm{~m}^{2}$.

Największe zagęszczenie mieszkań charakteryzowało w marcu 2011 r. gospodarstwa domowe pracowników (około $28 \mathrm{~m}^{2}$ na osobę). W latach 2009-2011 obserwujemy spadek tego zagęszczenia we wszystkich grupach społeczno-ekonomicznych gospodarstw, z wyjątkiem gospodarstw domowych rolników.

Wśród typów gospodarstw domowych największe zagęszczenie w marcu $2011 \mathrm{r}$. występowało w mieszkaniach małżeństw wielodzietnych oraz gospodarstw wielorodzinnych (odpowiednio około $19 \mathrm{~m}^{2}$ oraz poniżej $21 \mathrm{~m}^{2}$ powierzchni użytkowej na osobę). Zagęszczenie mieszkań w marcu 2011 r. w stosunku do marca 2009 r. zmniejszyło się znacząco w większości typów gospodarstw domowych, w tym najwięcej w gospodarstwach nierodzinnych wieloosobowych (o ponad 3 p.p).

$\mathrm{W}$ grupie gospodarstw $\mathrm{z}$ bezrobotnymi zagęszczenie mieszkań było znacznie wyższe niż w grupie gospodarstw bez bezrobotnych (przeciętnie odpowiednio prawie $24 \mathrm{~m}^{2}$ i ponad $35 \mathrm{~m}^{2}$ na osobę w tych grupach gospodarstw). Zarówno w grupie gospodarstw domowych bez bezrobotnych jak i z bezrobotnymi nastapił spadek zagęszczenia mieszkań w latach 2009-2011 (odpowiednio o prawie $3 \mathrm{~m}^{2}$ i o ponad $1 \mathrm{~m}^{2}$ ).

Zagęszczenie mieszkań w gospodarstwach domowych zamieszkujących wieś jest znacząco mniejsze niż w gospodarstwach domowych miejskich. Natomiast zróżnicowanie grup gospodarstw ze względu na zagęszczenie mieszkań według województw należy uznać za nieznaczne. We wszystkich grupach gospodarstw domowych, wyodrębnionych ze względu na klasę miejscowości zamieszkania jak i województwo zamieszkania, miał miejsce spadek zagęszczenia mieszkań w ostatnich dwóch latach. Najsilniejszy spadek zagęszczenia mieszkań obserwujemy przy tym w grupie gospodarstw domowych zamieszkujących wieś (o prawie $3 \mathrm{~m}^{2}$ ) oraz województwa pomorskie i łódzkie (o po ponad $6 \mathrm{~m}^{2}$ ).

Spośród uwzględnionych w badaniu urządzeń i instalacji najpowszechniejszy był w mieszkaniach gospodarstw badanych w marcu 2011 r. wodociąg, którego nie posiadało tylko 2,6 proc. Jednocześnie obserwujemy w ciagu ostatnich czterech lat wzrost odsetka mieszkań wyposażonych we wszystkie uwzględnione w badaniu urządzenia i instalacje (wykres 4.4.1).

\footnotetext{
${ }^{28}$ Wszystkie zmiany w zakresie warunków mieszkaniowych w latach 2007-2011 dotyczą próby panelowej z tych lat, czyli tych gospodarstw domowych, które zostały zbadane zarówno w 2007 r. jak i w 2009 r. oraz 2001 r.

${ }^{29}$ Zmiany w zakresie warunków mieszkaniowych w latach 2009-2011 dotyczą próby panelowej z tych lat, czyli tych gospodarstw domowych, które zostały zbadane zarówno 2009 r. jak i w 2011 r.
} 


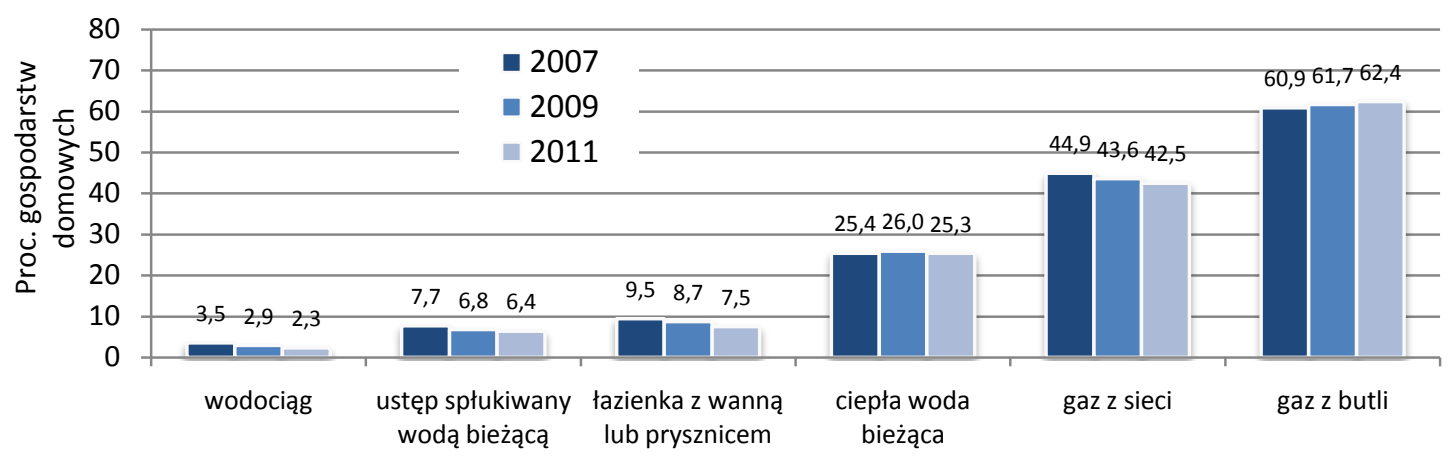

Wybrane urządzenia i instalacje

Wykres 4.4.1. Procent gospodarstw domowych nieposiadajacych wybranych urzadzeń $i$ instalacji w latach 2007-

2011 w próbie panelowej

W ostatnich dwóch latach także wzrósł nieznacznie odsetek mieszkań wyposażonych w instalacje i urządzenia, poza ciepłą wodą bieżącą, w przypadku której zmiany należy uznać za nieistotne (wykres 4.2.2.).

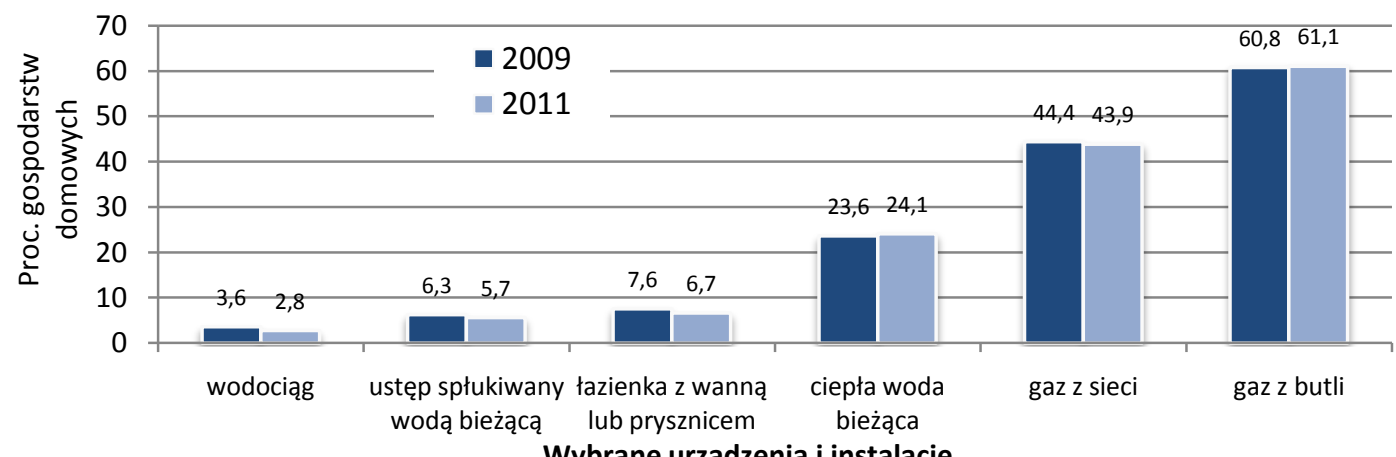

Wykres 4.4.2. Procent gospodarstw domowych nieposiadajacych wybranych urzqdzeń i instalacji w latach 2009-

2011 w próbie panelowej

Najczęściej mieszkania gospodarstw domowych nie posiadały ciepłej wody bieżącej (prawie 23 proc.). Nie posiadały jej przede wszystkim mieszkania gospodarstw domowych utrzymujących się z niezarobkowych źródeł (prawie 42 proc.) oraz rencistów (prawie 33 proc.). Wzrost odsetka mieszkań, w ciągu ostatnich dwóch lat, wyposażonych w instalacje i urządzenia, obserwujemy we wszystkich grupach społeczno-ekonomicznych gospodarstw domowych, poza wyposażeniem w ciepłą wodę bieżącą gospodarstw domowych rolników i pracowników.

W grupie gospodarstw z bezrobotnymi wyposażenie mieszkań w urządzenia i instalacje było znacznie mniej powszechne niż w grupie gospodarstw bez bezrobotnych. Przykładowo, ciepłej bieżącej wody nie posiadało w tych grupach gospodarstw domowych odpowiednio prawie 28 i około 22 proc. mieszkań. Stan wyposażenia mieszkań, zajmowanych przez gospodarstwa domowe w analizowanych dwóch grupach gospodarstw, we wszystkie uwzględnione urządzenia i instalacje, poza wyposażeniem w ciepłą wodę bieżącą gospodarstw domowych bez bezrobotnych, zwiększył się w ostatnich dwóch latach.

Mieszkaniami bez ciepłej wody bieżącej najczęściej dysponowały gospodarstwa nierodzinne jednoosobowe (około 30 proc.). W ciągu ostatnich dwóch lat najsilniejszy wzrost odsetka gospodarstw domowych niewyposażonych w ciepłą wodę bieżącą wystąpił w przypadku gospodarstw nierodzinnych wieloosobowych (o ponad 9 p.p). Jednocześnie obserwujemy znaczący wzrost odsetka mieszkań w tym okresie nie posiadających ciepłej wody bieżącej w grupach gospodarstw domowych wielorodzinnych i małżeństw wielodzietnych (odpowiednio o ponad 3 i około 2 p.p).

Relatywnie najczęściej mieszkania bez ciepłej wody bieżącej posiadały gospodarstwa domowe wiejskie (ponad 32 proc. gospodarstw). W ostatnich dwóch latach we wszystkich klasach miejscowości zamieszkania zaszła w zasadzie poprawa $\mathrm{w}$ wyposażeniu mieszkań $\mathrm{w}$ analizowane instalacje, poza najmniejszymi miastami i wsią w przypadku ciepłej wody bieżącej.

Gospodarstwa domowe nieposiadające w mieszkaniach ciepłej wody bieżącej zamieszkiwały przede wszystkim województwo świętokrzyskie (prawie 38 proc. mieszkań w tym województwie nie posiadało ciepłej bieżącej wody). W latach 2009-2011 w zdecydowanej większości województw nastąpiła poprawa stopnia wyposażenia mieszkań w urządzenia i instalacje.

Mieszkania zajmowane przez gospodarstwa domowe w marcu 2011 r. najczęściej posiadały centralne ogrzewanie indywidualne lub zbiorowe (po odpowiednio prawie 45 i prawie 42 proc. gospodarstw). Jednakże 
jeszcze w ponad 13 proc. gospodarstw mieszkania były ogrzewane piecami na opał. Mieszkania ogrzewane piecami na opał występowały przede wszystkim w grupie gospodarstw utrzymujących się z niezarobkowych źródeł i rencistów (odpowiednio prawie 33 i prawie 26 proc. gospodarstw posiadało ten typ ogrzewania mieszkań) oraz gospodarstw nierodzinnych wieloosobowych (około 23 proc. gospodarstw z tej grupy). Ten typ ogrzewania występował w 22 proc. mieszkań gospodarstw domowych z bezrobotnymi oraz tylko w około 12 proc. mieszkań gospodarstw domowych bez bezrobotnych. Gospodarstwa domowe posiadające mieszkania ogrzewane piecami na opał zamieszkiwały najczęściej wieś ( około 22 proc. gospodarstw wiejskich) oraz województwa lubelskie i podkarpackie (odpowiednio w ponad 17 i prawie 17 proc. gospodarstw z tych województw).

W ciagu ostatnich czterech lat nastąpił znaczący spadek (o prawie 3 p.p) odsetka mieszkań, w których stosowane były piece na opał na rzecz centralnego ogrzewania (wykres 4.4.3).

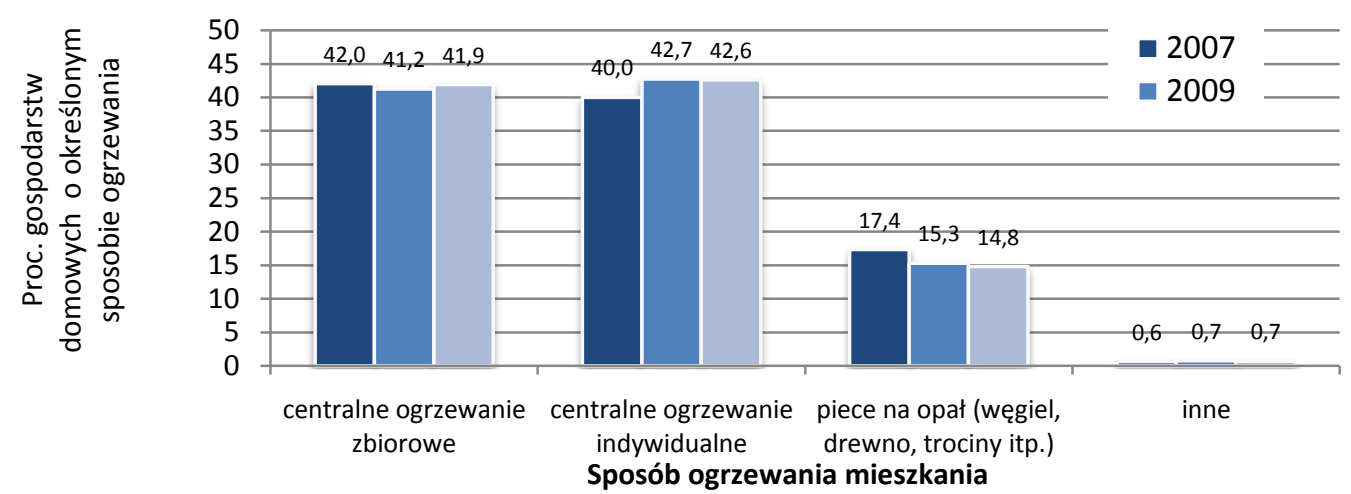

Wykres 4.4.3. Sposób ogrzewania mieszkań gospodarstw domowych w latach 2007-2011 w próbie panelowej.

Także w latach 2009-2011 (wykres 4.4.4) obserwujemy spadek odsetka mieszkań z piecami na opał na rzecz centralnego ogrzewania (o ponad 1 punkt procentowy).

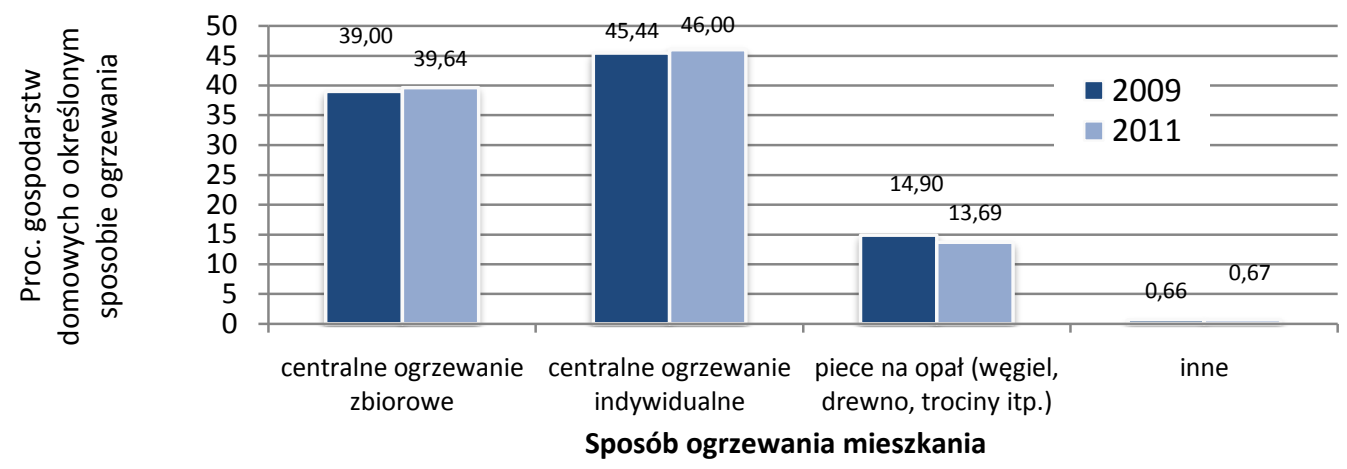

Wykres 4.4.4. Sposób ogrzewania mieszkań gospodarstw domowych w 2009 i 2011 r. w próbie panelowej.

W ostatnich dwóch latach najczęściej tego typu zmiany obserwujemy w grupach gospodarstw domowych rolników i rencistów, nierodzinnych wieloosobowych, małżeństw wielodzietnych, zamieszkujących wieś oraz województwa opolskie i podlaskie. Są to tym samym te grupy gospodarstw, których relatywnie największe odsetki mieszkań stosowały ogrzewanie piecami na opał w $2009 \mathrm{r}$.

Ponad 7 proc. gospodarstw domowych zalegało w marcu 2011 r. ze stałymi opłatami za mieszkanie (czynszem), a prawie 4 proc. $z$ opłatami za gaz i energię elektryczną. Odsetek mieszkań zalegających z opłatami za mieszkanie oraz za gaz i energię elektryczną uległ znaczącemu zmniejszeniu w latach 2007-2011 (odpowiednio o prawie 2 i o ponad 1 p.p. wykres 4.4 .5 i 4.4.7). Natomiast w ostatnich 2 latach wzrosły, jednakże nieistotnie, zaległości z opłatami za mieszkanie oraz gaz i energię (o mniej niż 1 p.p., wykres 4.4.6 i wykres 4.4.8). 


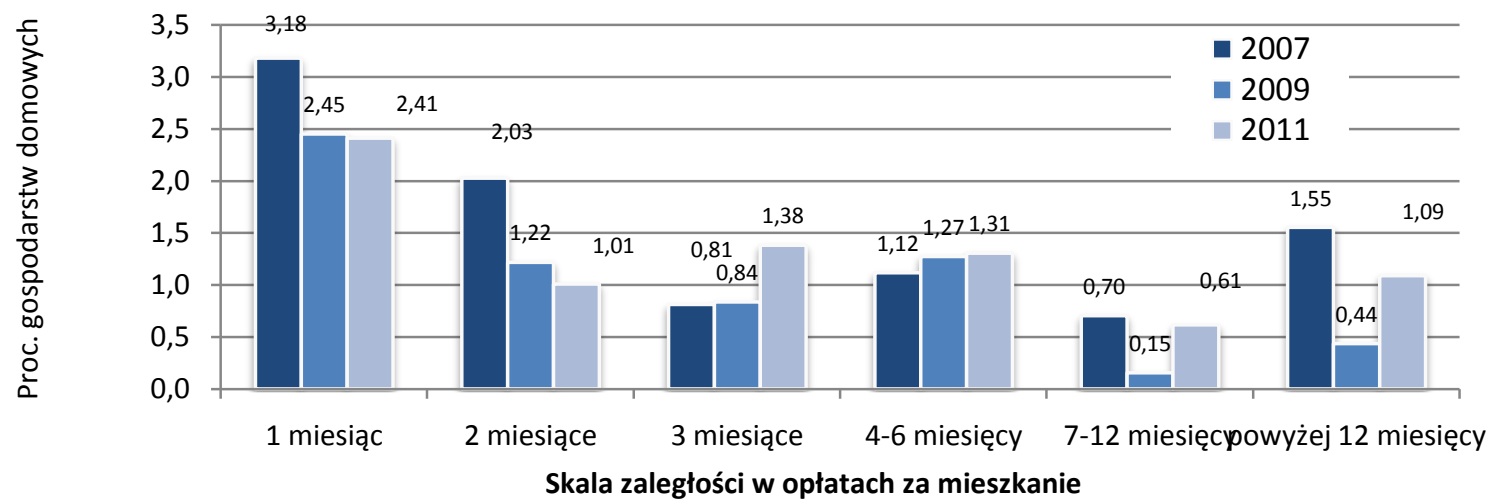

Wykres 4.4.5. Zalegtości gospodarstw domowych w opłatach za mieszkanie (czynsz) w latach 2007-2011 w próbie panelowej.

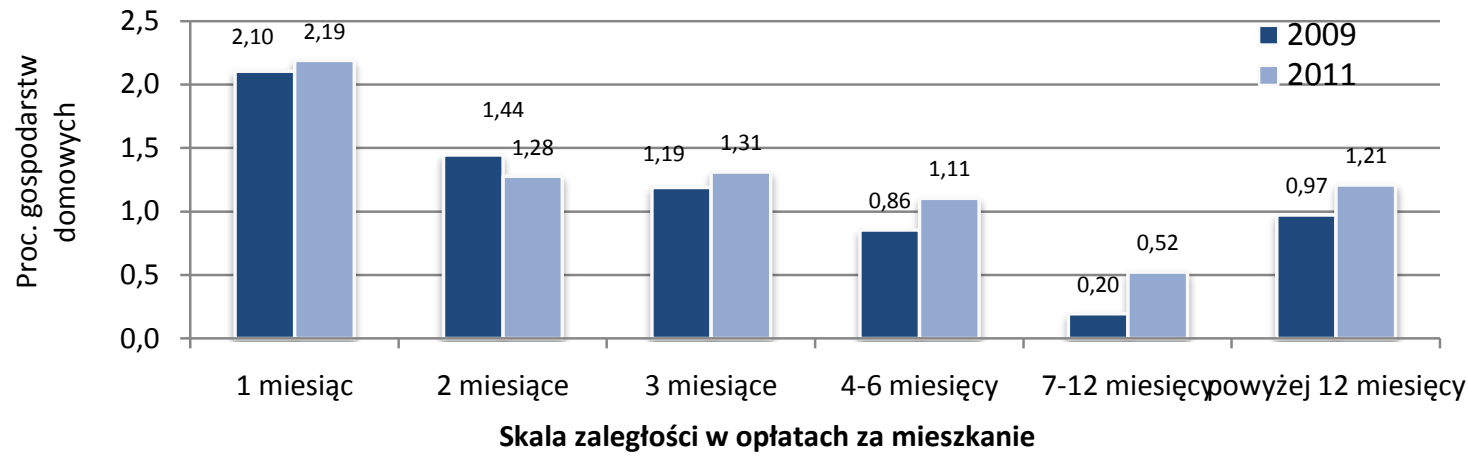

Wykres 4.4.6. Zaległości gospodarstw domowych w opłatach za mieszkanie (czynsz) w latach 2009-2011 w próbie panelowej.

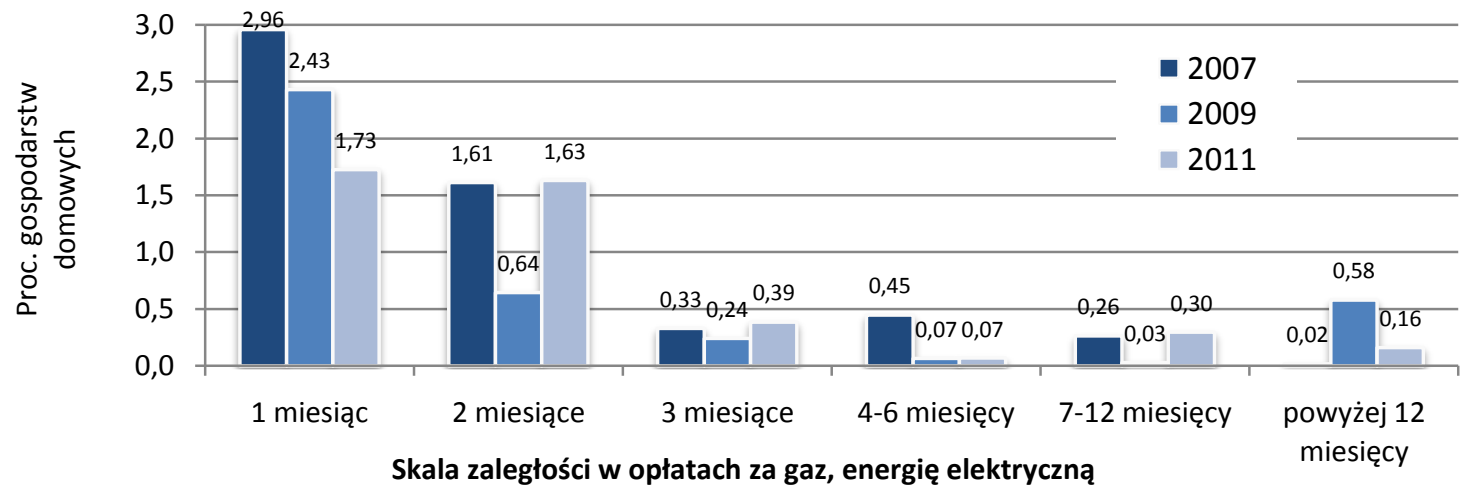

Wykres 4.4.7. Zaleglości gospodarstw domowych w oplatach za gaz i energię elektrycznq w latach 2007-2011 w próbie panelowej.

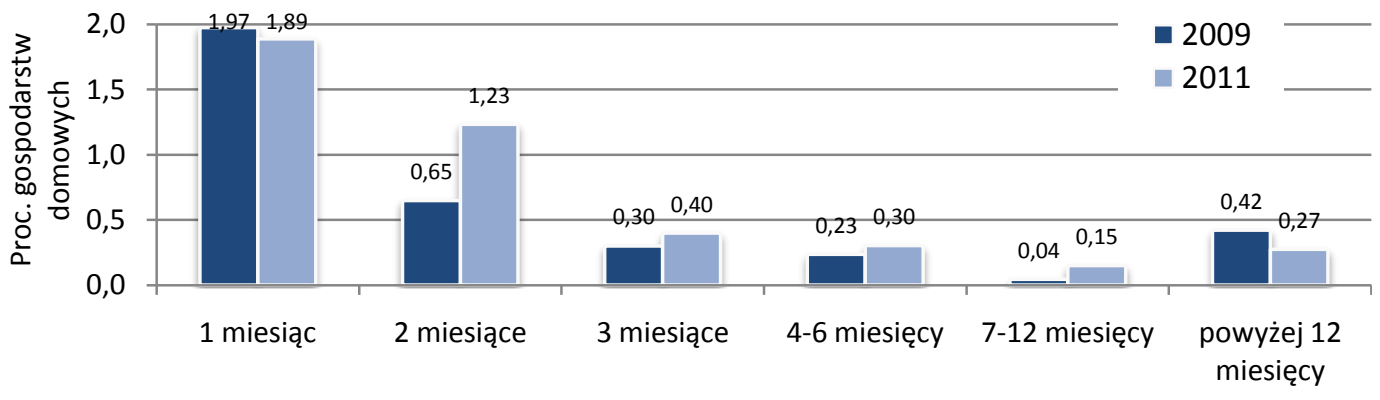

Skala zaległości w opłatach za gaz, energię elektryczną

Wykres 4.4.8. Zaległości gospodarstw domowych w oplatach za gaz i energię elektrycznq w latach 2009-2011 w próbie panelowej. 
Najczęściej gospodarstwa domowe zalegające z opłatami za mieszkanie oraz za gaz i energię elektryczną występowały w grupie gospodarstw utrzymujących się z niezarobkowych źródeł (odpowiednio prawie 27 i prawie 13 proc.) oraz w grupach gospodarstw rodzin niepełnych (odpowiednio prawie 14 i prawie 8 proc.) i małżeństw wielodzietnych (odpowiednio ponad 13 i ponad 7 proc.). Należy zwrócić uwagę, że także w tych grupach gospodarstw domowych obserwujemy największą częstotliwość występowania takich gospodarstw, które zalegają ze stałymi opłatami za mieszkanie ponad 12 miesięcy.

W ostatnich dwóch latach znaczący wzrost odsetka gospodarstw domowych zalegających z opłatami za mieszkanie obserwujemy $w$ grupie gospodarstw pracujących na własny rachunek (o ponad 3 p.p). W przypadku opłat za gaz i energię elektryczną znaczący wzrost odsetka gospodarstw domowych, które zalegają z tymi opłatami nastąpił wyłącznie w grupach gospodarstw domowych rodzin niepełnych oraz wielorodzinnych.

Gospodarstwa domowe zalegające $\mathrm{z}$ opłatami za użytkowanie mieszkań oraz gaz i energię elektryczną występowały znacznie częściej wśród gospodarstw domowych z bezrobotnymi niż wśród gospodarstw domowych bez bezrobotnych.

Zróżnicowanie grup gospodarstw, wyodrębnionych ze względu na klasę miejscowości zamieszkania, dotyczące skali nie uiszczania w terminie opłat za mieszkanie oraz opłat za gaz i energię elektryczną nie było w marcu $2011 \mathrm{r}$. znaczące. Jednakże z opłatami za mieszkanie częściej zalegają gospodarstwa domowe miejskie niż wiejskie, a w przypadku opłat za energię elektryczną i gaz obserwujemy sytuację odwrotną. W okresie marzec 2009-marzec 2011 nastapił znaczący wzrost odsetka gospodarstw domowych zalegających z opłatami za mieszkanie w dużych miastach o liczbie mieszkańców powyżej 500 tys. W przypadku opłat za gaz i energię elektryczną znaczący wzrost odsetka gospodarstw domowych zalegających z tymi opłatami wystapił także tylko w grupie gospodarstw domowych zamieszkujących największe miasta o liczbie mieszkańców powyżej 500 tys.

Najwyższe odsetki gospodarstw domowych nieuiszczających w terminie opłat zarówno za czynsz jak i za gaz oraz energię elektryczną występowały w marcu 2011 r. w województwie łódzkim.

Spłat rat kredytu mieszkaniowego nie dokonywało w terminie niecałe 3 proc. gospodarstw domowych badanych w marcu 2011 r. Najczęściej zaległości gospodarstw domowych w spłatach kredytu mieszkaniowego występowały w grupie gospodarstw rolników (w prawie 19 proc. gospodarstw) oraz w grupie gospodarstw rodzin niepełnych (w ponad 5 proc. gospodarstw). W latach 2007-2011 nie nastapiły istotne zmiany odsetka gospodarstw domowych zalegających ze spłatą kredytu mieszkaniowego (wykres 4.4.9).

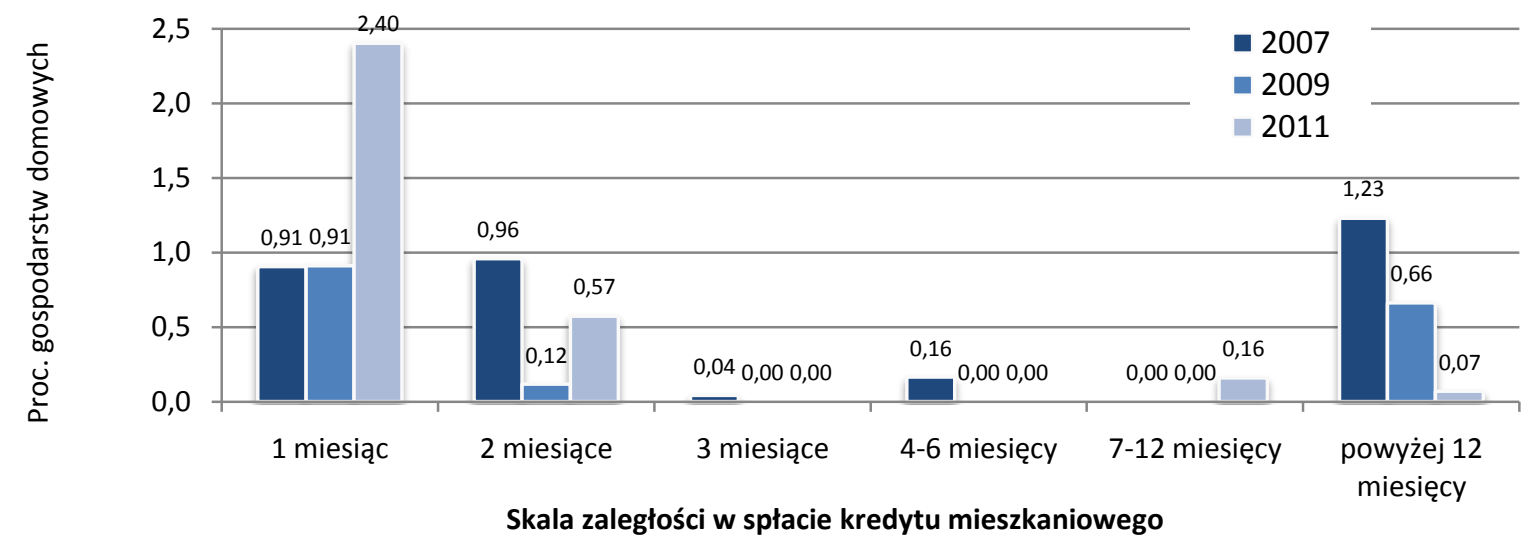

Wykres 4.4.9. Zaległości gospodarstw domowych w spłacie kredytu mieszkaniowego w latach 2007-2011 w próbie panelowej.

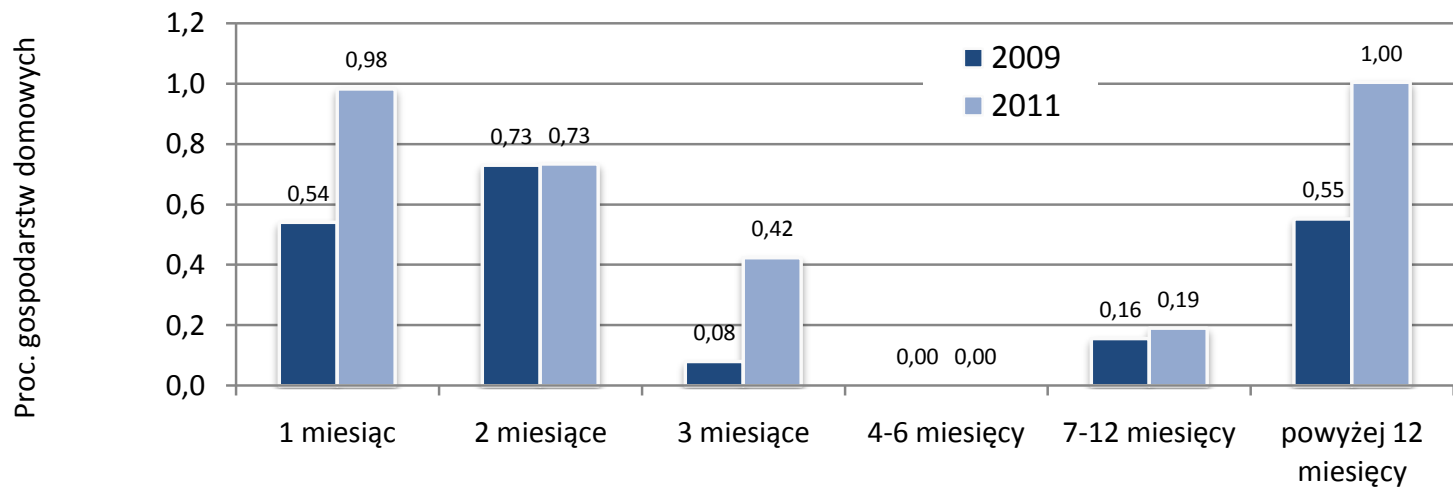

Skala zaległości w spłacie kredytu mieszkaniowego

Wykres 4.4.10. Zaległości gospodarstw domowych w spłacie kredytu mieszkaniowego w latach 2009-2011 w próbie panelowej. 
Natomiast w roku 2011 w stosunku do roku 2009 obserwujemy wzrost odsetka gospodarstw domowych mających zaległości w opłacie kredytu mieszkaniowego (o ponad 1 punkt procentowy, wykres 4.4.10). W ostatnich dwóch latach nie nastąpił znaczący wzrost odsetka gospodarstw domowych zalegających ze spłatą kredytu w żadnej $\mathrm{z}$ analizowanych grup społeczno-ekonomicznych gospodarstw domowych.

Gospodarstwa domowe z bezrobotnymi nieznacznie częściej zalegały w marcu 2011 r. ze spłatą kredytu mieszkaniowego niż gospodarstwa domowe bez bezrobotnych. W ostatnich dwóch latach brak jest znaczących zmian odsetka gospodarstw domowych mających tego typu trudności finansowe w obu tych grupach gospodarstw.

Gospodarstwa mające zaległości w spłacie rat kredytu mieszkaniowego najczęściej zamieszkiwały wieś (około 5 proc. gospodarstw wiejskich) oraz województwa warmińsko-mazurskie (prawie 9 proc. gospodarstw) i opolskie (prawie 6 proc. gospodarstw). W okresie marzec 2009-marzec 2011 nie obserwujemy znaczących zmian odsetka gospodarstw domowych zalegających ze spłatą kredytu mieszkaniowego w żadnej z klas miejscowości zamieszkania.

Zdecydowana większość badanych gospodarstw domowych (ponad 79 proc. gospodarstw) uważało, że ich warunki mieszkaniowe w marcu 2011 r. w porównaniu do sytuacji w marcu 2009 r. nie zmieniły się. Około 9 proc. gospodarstw uznało, że uległy one pogorszeniu, a około 10 proc., że poprawiły się. W porównaniu do ocen formułowanych w marcu 2009 zmniejszył się odsetek gospodarstw domowych formułujących zarówno oceny negatywne jak i oceny pozytywne (odpowiednio o około 4 i prawie 2 p.p). Gospodarstwa deklarujące pogorszenie się warunków mieszkaniowych najczęściej występowały w grupie gospodarstw domowych pracowników i pracujących na własny rachunek (odpowiednio ponad $12 \mathrm{i}$ ponad 11 proc. gospodarstw) oraz grupach gospodarstw małżeństw z 2 i 1 dzieckiem (po ponad 12 proc. gospodarstw).

Zróżnicowanie gospodarstw oceniających, że ich warunki mieszkaniowe uległy pogorszeniu w stosunku do sytuacji sprzed dwóch lat, według klasy miejscowości zamieszkania, nie było znaczące. Najczęściej na pogorszenie się tych warunków wskazywały gospodarstwa domowe zamieszkujące największe miasta oraz wieś (po prawie 11 proc. gospodarstw). Gospodarstwa domowe oceniające pesymistycznie zmiany warunków mieszkaniowych najczęściej zamieszkiwały województwa dolnośląskie i świętokrzyskie (po około 12 proc. gospodarstw z tych województw).

\title{
4.4.2. Zmiana warunków mieszkaniowych w latach 2000-2011
}

\author{
Janusz Czapiński
}

Analiza warunków mieszkaniowych w latach 2000-2011 w całych próbach pokazuje systematyczny spadek odsetka gospodarstw domowych, w których nie ma zasilania wodą z wodociągu (z 5,5 do 2,6 proc.), brakuje ustępu spłukiwanego bieżącą wodą (z 11,2 do 5,1 proc.), nie ma łazienki z wanną lub prysznicem (z 13,8 do 6,3 proc.) i mieszkań pozbawionych ciepłej wody bieżącej (z 29,6 do 22,8 proc.) (wykres 4.4.11).

Mniej systematyczne zmiany w minionym dziesięcioleciu nastapiły w zaległościach opłat za mieszkanie. Największy odsetek gospodarstw zalegających z opłatą czynszu powyżej 2 miesięcy przypadł na lata 2003 i 2005. W późniejszym okresie obserwujemy znaczący spadek odsetka takich gospodarstw (wykres 4.4.12). W 2011 r. nastąpiła stabilizacja zaległości za czynsz.

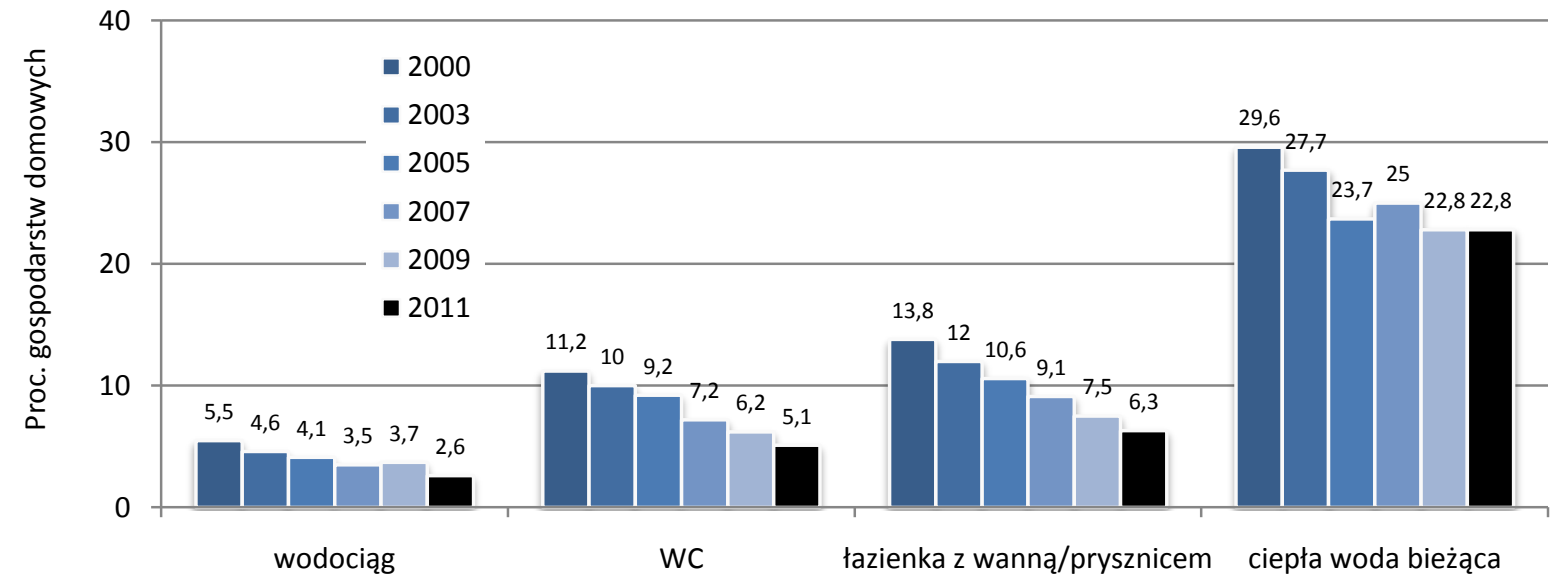

Wykres 4.4.11.Procent gospodarstw domowych, w których nie było wybranych urzadzeń i instalacji w latach $2000-$ 2011 w catych próbach

Podobnie do zmian w zaległościach opłat czynszu wygląda dynamika zaległości w opłatach za gaz i energię elektryczną (wykres 4.4.13). Obecnie zaledwie 4,1 proc. ma takie zaległości w porównaniu z 6,1 proc. w roku 2005. Może to świadczyć o bardziej rygorystycznym postępowaniu dostawców wobec gospodarstw zalegających $\mathrm{z}$ płatnościami i wynikającej stąd większej obawie o odłączenie mieszkania od sieci gazowej lub elektrycznej. 
Zaległości w spłacie kredytu mieszkaniowego utrzymały się na poziomie 2009 r. i były znacząco niższe niż przed rokiem 2005 (wykres 4.4.14).

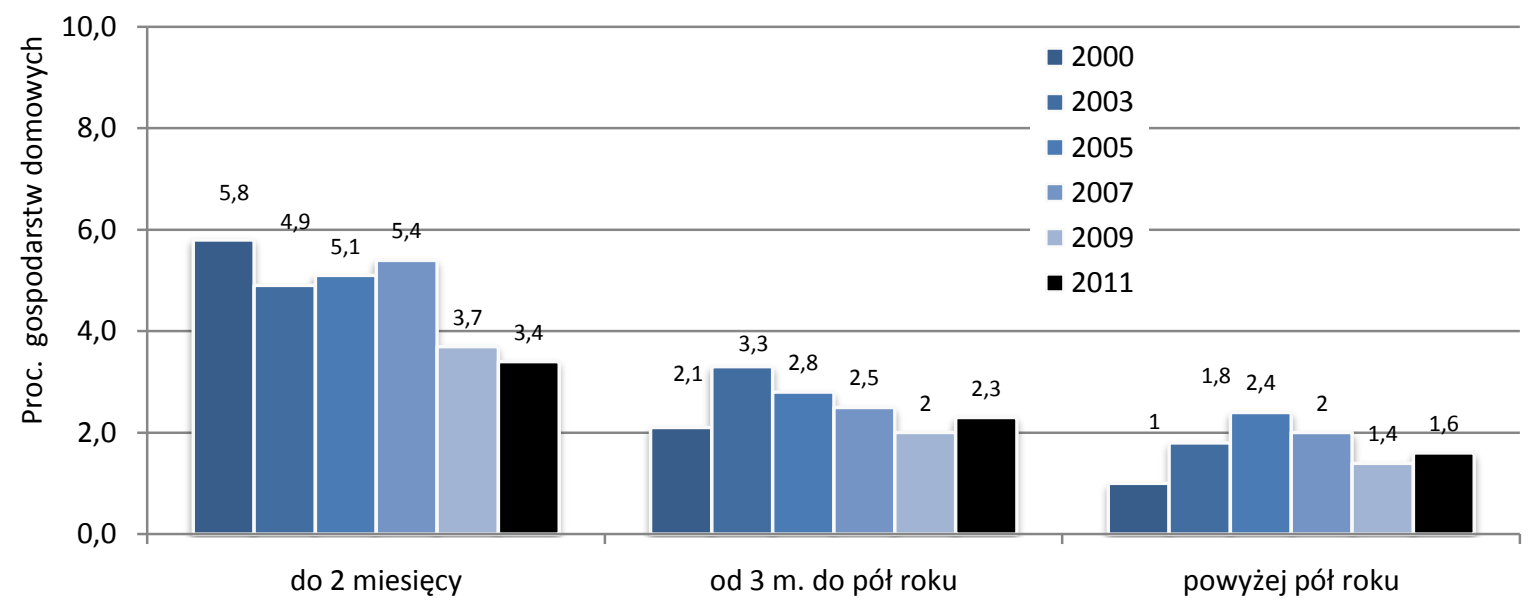

Zaległości w opłatach za mieszkanie

Wykres 4.4.12. Zaległości gospodarstw domowych w optatach za mieszkanie (czynsz) w latach 2000-2011 w catych próbach

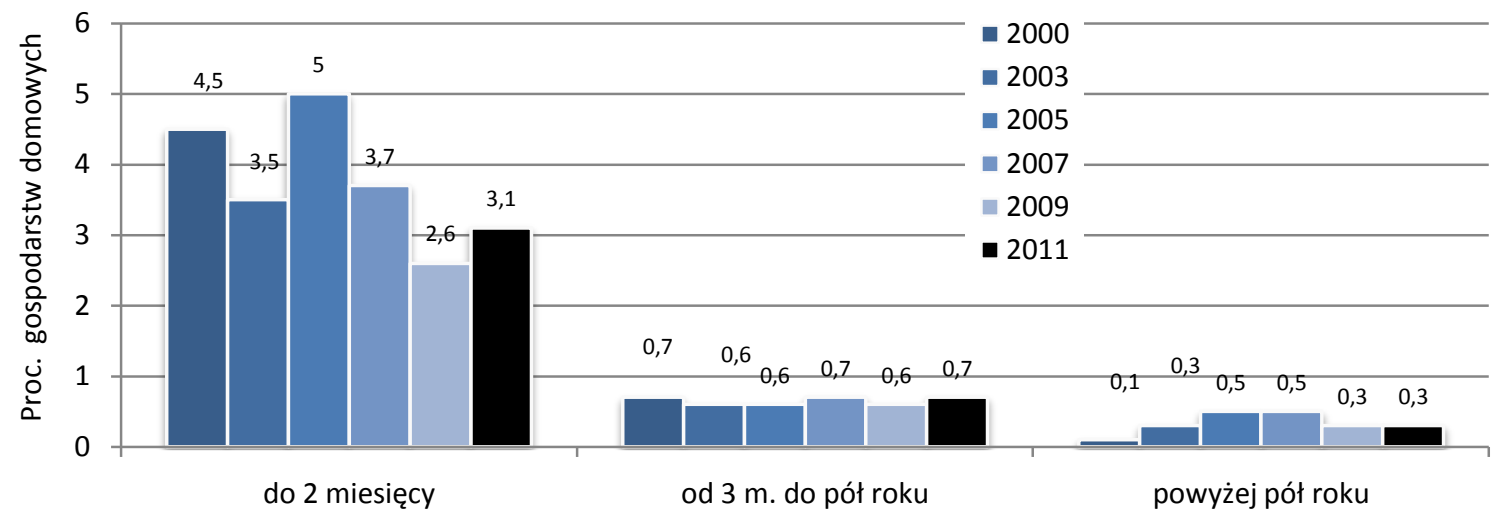

Zaległości w opłatach za gaz i energię

Wykres 4.4.13. Zaległości gospodarstw domowych w opłatach za gaz i energię elektryczna w latach 2000-2011 w catych próbach

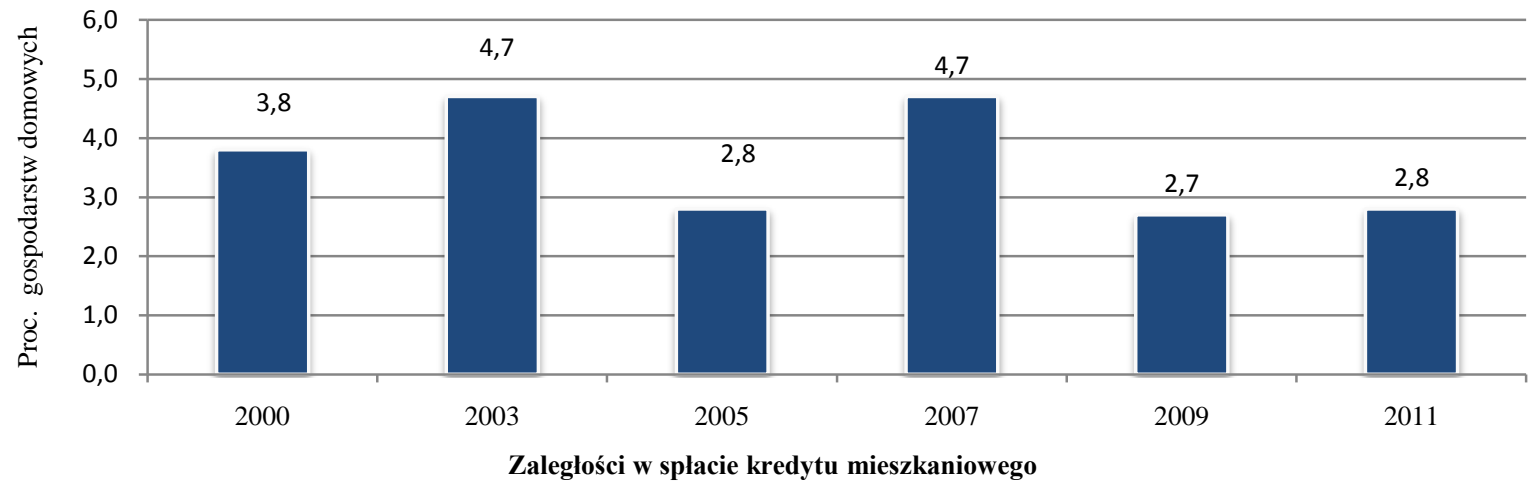

Wykres 4.4.14. Odsetek gospodarstw domowych zalegajacych ze spłata kredytu mieszkaniowego w latach 2000 2011 w catych próbach 


\subsection{Edukacja}

\subsubsection{Status edukacyjny członków gospodarstw domowych \\ Izabela Grabowska, Irena E. Kotowska}

Ocena aktywności edukacyjnej ludności dokonywana jest na podstawie zakresu korzystania z określonej usługi edukacyjnej w trybie szkolnym (nauka w szkołach w trybie stacjonarnym, wieczorowym i zaocznym, wszelkie studia podyplomowe) lub pozaszkolnym. Odsetek osób w określonej grupie wieku korzystających z danej formy usługi edukacyjnej jest podstawą do oceny zakresu korzystania z niej. Miernik ten dla usług edukacyjnych świadczonych w trybie szkolnym odpowiada wskaźnikowi skolaryzacji, dla usług dotyczących dzieci w wieku do 6 lat oznacza wskaźnik dostępności (ang. coverage rate) i jest stosowany do oceny zasięgu opieki instytucjonalnej nad dziećmi, natomiast dla osób wieku 25 lat i więcej może służyć do oceny ich aktywności edukacyjnej. W analizie aktywności edukacyjnej osób dorosłych, czyli osób w wieku 18 lat i więcej, uwzględnione zostaną także formy aktywności edukacyjnej oraz status respondentów na rynku pracy.

\subsubsection{Zaangażowanie członków gospodarstw domowych w aktywność edukacyjna}

W tabeli 4.5.1. zamieszczono wartości wskaźnika korzystania z usług edukacyjnych wyznaczone dla lat 2000, 2003, 2005, 2007 oraz 2009 i 2011, przy czym w badaniach z pięciu ostatnich rund Diagnozy uwzględniono także aktywność edukacyjną w trybie pozaszkolnym, co ma znaczenie dla oceny aktywności edukacyjnej osób dorosłych. W komentarzu skoncentrujemy się na wynikach ostatnich trzech rund i uwzględnimy trendy zmian w latach 20002011 .

Wyniki z 2011 r. wskazują na istotny wzrost korzystania z opieki w przedszkolach lub żłobków (29,1 proc.). W poprzednich badaniach, z wyjątkiem roku 2003, w skali całego kraju zaledwie co piąte dziecko w wieku do 6 lat korzystało z opieki w przedszkolu lub żłobku. Poprawa dostępu do tych usług wystapiła we wszystkich klasach miejscowości zamieszkania, szczególnie w miastach powyżej 500 tys. mieszkańców (o 17 p.p. w porównaniu z 2009 r.) i na wsi (o 7 p.p.). Nadal dzieci w miastach znacznie częściej pozostawały w tych placówkach opiekuńczych niż na wsi, gdzie jedynie 20 proc. dzieci objętych było taką opieką (w przeszłości miernik ten wahał się między 8 proc. a 11-13 proc.). W przeciwieństwie do poprzednich rund badania, które ukazywały pogłębienie zróżnicowania przestrzennego dostępu do opieki instytucjonalnej między miastem (nawet małym) a wsią, w $2011 \mathrm{r}$. odnotowano istotne zmniejszenie się luki pomiędzy miastami, nawet tymi największymi, a wsią. Zwiększenie liczby urodzeń, które obserwowano w Polsce od 2004 r. do 2010 r., będące rezultatem realizacji odroczonych urodzeń i wzrostu liczby kobiet w wieku rozrodczym (wyż demograficzny lat osiemdziesiątych XX wieku), zwiększyło zapotrzebowanie na miejsca w żłobkach i przedszkolach. Rynek tych usług w miastach, szczególnie usług prywatnych, szybciej dostosował się do zwiększonego popytu, co dodatkowo pogłębiło różnice terytorialne w dostępie do tych placówek w poprzednich okresach badania. W 2011 r. tak znaczny wzrost korzystania z opieki oferowanej przez przedszkola lub żłobki jest związany niewątpliwie z dostępnością środków z Europejskiego Funduszu Społecznego w ramach Programu Kapitał Ludzki, z którego możliwe uzyskanie dofinansowania na tworzenie przedszkoli, szczególnie na terenach wiejskich. W kolejnej rundzie badania możliwe będzie zaobserwowanie skutków innej interwencji państwa w tym zakresie, tj. wejścia w życie Ustawy z dnia 4 lutego 2011 r. o opiece nad dziećmi do lat trzech (Dz. U. 2011, nr 45, poz. 235).

Ponadto, podobnie jak w latach ubiegłych, zdecydowana większość dzieci korzystała z publicznych żłobków i przedszkoli $(84,7$ proc. W skali kraju, 90,7 proc. w miastach powyżej 500 tys. mieszkańców oraz 83,7 proc. na wsiach), choć znaczenie niepublicznych placówek wzrasta.

Pomimo tych korzystnych zmian, dostępność tej formy usług edukacyjno-opiekuńczych w Polsce nadal należy do najniższych w Unii Europejskiej. Szczególnie utrzymujący się głęboki niedobór opieki instytucjonalnej nad dziećmi na wsiach może być czynnikiem ograniczającym wzrost aktywności zawodowej kobiet na wsi, a zwłaszcza podejmowanie przez nich zatrudnienia w sektorze pozarolniczym. Konieczne zmiany struktury zatrudnienia ludności wiejskiej związane z przesunięciem części zasobów pracy do sektora pozarolniczego nadają zwiększeniu dostępności opieki instytucjonalnej nad dzieckiem na wsi szczególne znaczenie. Ponadto podkreśla się, że dobrej jakości usługi opiekuńcze, dostępne dla rodziców po odpowiednio niskiej cenie, są skutecznym sposobem zmniejszania nierówności edukacyjnych oraz ekonomicznych (por. np. Kotowska, Sztanderska, Wóycicka 2007, Szukalski, Warzywoda-Kruszyńska, 2005). Niestety w Polsce dostępność tej formy opieki należy do najniższych w Unii Europejskiej.

Podobnie jak w latach ubiegłych, w 2011 r. nie zaobserwowano istotnych terytorialnych różnic w dostępie do edukacji dzieci w wieku 7-15 lat, które w zdecydowanej większości uczą się w szkołach publicznych (od 88 proc. w miastach największych do 94,1 proc. na wsiach). W skali kraju oraz na wsi około 90 proc. dzieci w tym wieku uczyło się, a w miastach ten odsetek wahał się od 88 proc. do 92 proc. W porównaniu z wynikami rund z 2005 r. i 2007 r., utrzymał się zanotowany w 2009 r. nieznaczny spadek stopnia skolaryzacji dzieci w tej grupie wieku (szczególnie dla miast od 20 do 200 tys. mieszkańców), który trudno wytłumaczyć. Wskaźniki, jakie uzyskano w 
2003 r., przypisywano wpływowi reformy edukacyjnej z 1999 r. Wtedy do tej grupy wieku zaliczono po raz pierwszy nie tylko dzieci i młodzież ze szkół podstawowych, lecz także z gimnazjów.

W przeciwieństwie do wyników poprzednich rund badania, w $2011 \mathrm{r}$. zaobserwowano istotne różnice terytorialne w korzystaniu ze szkół dla młodzieży w wieku 16-19 lat (zarówno w formie dziennej, jak i zaocznej oraz eksternistycznej). Odsetek młodzieży w tym wieku korzystającej z nauki w dowolnym typie szkoły nieznacznie zwiększył się w miastach powyżej 500 tys. mieszkańców (o 1,6 p.p.) oraz w miastach od 20 do 100 tys. mieszkańców (o 1,1 p.p.) do około 98 proc., podczas gdy w pozostałych typach miast i na wsi zmalał. Największy spadek zanotowano dla miast średnich (100-200 tys. mieszkańców) do około 86,4 proc. (o 10,7 p.p.), na wsi spadek wskaźnika młodzieży uczącej się w różnych typach szkół był mniejszy (o 1,7 p.p.), osiagając w 2011 r. 92,5 proc. Zmiany te przełożyły się na spadek wskaźnika korzystania z usług edukacyjnych dla młodzieży w tej grupie wieku o 1,9 p.p. do poziomu 93,5 proc., co zahamowało obserwowany w latach poprzednich trend wzrostowy. Ponadto, należy wskazać na niewielkie znaczenie niepublicznych szkół dla młodzieży w tej grupie wieku - nie więcej niż 3 proc. młodzieży uczyło się w szkołach niepublicznych niezależnie od typu miejsca zamieszkania, czyli znacznie mniej niż w przypadku szkół podstawowych i gimnazjalnych.

Pod pojęciem aktywności edukacyjnej osób dorosłych rozumie się uczestnictwo osób w wieku 18 lat $\mathrm{i}$ więcej w różnych formach kształcenia, jednak ze względu na przyjęte powyżej grupowanie według wieku analiza nasza dotyczy osób w wieku 20 lat więcej.

Obraz zróżnicowania terytorialnego dostępu do usług edukacyjnych opisany dla dzieci i młodzieży w wieku 7 19 lat ulega zasadniczej zmianie w odniesieniu do aktywności edukacyjnej osób w starszych grupach wieku. Odsetek osób w wieku 20-24 lata uczących się w trybie szkolnym i pozaszkolnym nieznacznie zmalał (o 2,1 p.p.) w 2011 r. i wyniósł 58,8 proc. (wobec 61 proc. w 2007 r. i 2009 r.). Znacząco zmieniło się natomiast korzystanie z usług edukacyjnych $\mathrm{w}$ tej grupie wieku w ujęciu terytorialnym. Znaczny spadek wskaźnika korzystania $\mathrm{z}$ usług edukacyjnych zanotowano w miastach powyżej 500 tys. mieszkańców - z 83 proc. w 2009 r. do 73,5 proc. w 2011 r., w miastach od 100-200 tys. mieszkańców - z 66,9 proc. w 2009 r. do 57,10 proc. w 2011 r., w miastach od 20 do 100 tys. mieszkańców - z 65,8 proc. do 61,2 proc. Stabilizacji korzystania z usług edukacyjnych w miastach dużych - od 200 do 500 tys. mieszkańców (72,8 proc.) towarzyszył nieznaczny wzrost tego wskaźnika od 58 proc. w 2009 r. do 60,1 proc. w 2011 r. w miastach najmniejszych (poniżej 20 tys. mieszkańców), podobnie jak dla mieszkańców wsi (od 47,6 proc. w 2009 r. do 49,4 proc. w 2011 r.). Zmniejszyły się zatem różnice terytorialnie w korzystaniu z usług edukacyjnych do poziomu obserwowanego w pierwszej połowie tej dekady. Na tym poziomie edukacji wzrasta rola placówek niepublicznych, korzystało z nich 15,6 proc. uczących się osób w największych miastach w porównaniu z 11,9 proc. na wsiach.

Na podkreślenie zasługują pojawiające się w tej grupie wieku istotne różnice aktywności edukacyjnej między kobietami a mężczyznami: kobiety wyraźnie częściej niż mężczyźni kształcą się (68,1 proc. kobiet w 2011 r., 67 proc. w 2009 r., 63 proc. kobiet w 2007 r. wobec 52,5 proc. mężczyzn w 2011 r., 55 proc. w 2009 r., 57 proc. w 2007 r.). Tendencja wzrostowa aktywności edukacyjnej kobiet ulega stopniowemu spowolnieniu, jednak utrzymujący się spadek aktywności edukacyjnej mężczyzn w wieku 20-24 lata powiększa różnice płci w korzystaniu z usług edukacyjnych.

Wyraźnie zmienia się zróżnicowanie aktywności edukacyjnej kobiet i mężczyzn w wieku 20-24 lata według miejsca zamieszkania. W 2011 r. kobiety w wieku 20-24 lata zamieszkałe w miastach w mniejszym stopniu niż w 2009 r. korzystały z usług edukacyjnych w przeciwieństwie do mieszkanek wsi. Odpowiedni wskaźnik waha się w zależności od wielkości miast między 61,3 proc. a 80,2 proc. (w 2009 r. $64-87$ proc., w 2007 r. $60-84$ proc.), na wsi wynosi natomiast 60,8 proc. (w 2009 r. 54,5 proc., w 2007 r. 54 proc.). Odsetek mężczyzn zamieszkujących w miastach i korzystających z usług edukacyjnych w trybie szkolnym i pozaszkolnym wynosi od 54,1 proc. do 72,9 proc. (w 2009 r. 51-81 proc., w 2007 r. 57-81 proc.) wobec wartości 40,9 proc. na wsi (w 2009 r. 42 proc., w 2007 r. 43 proc.), co wskazuje na spadek aktywności edukacyjnej mężczyzn w wieku 20-24 lata we wszystkich klasach miejscowości zamieszkania. Pozytywnym zjawiskiem jest niewątpliwie zwiększenie aktywności edukacyjnej kobiet na wsiach, jednak ogólna tendencja wzrostowa uległa zahamowaniu, szczególnie dla miast największych i średnich. Utrzymujący się spadek aktywności edukacyjnej mężczyzn zarówno w miastach (za wyjątkiem najmniejszych) jak i na wsi, pogłębia lukę aktywności edukacyjnej pomiędzy kobietami i mężczyznami, szczególnie na wsiach i w największych miastach.

Zakres korzystania z usług edukacyjnych zmniejsza się zdecydowanie w następnej grupie wieku, jest także niższy w porównaniu z poprzednią rundą badania, co oznacza odwrócenie wcześniej zaobserwowanych tendencji. Udział osób w wieku 25-29 lat aktywnych edukacyjnie wyniósł w 2011 r. 15,1 proc. (18 proc. w 2009 r., 17 proc. w 2007 r.). Ta zmiana wynika przede wszystkim z pogorszenia wskaźników dotyczących miast od 100 do 200 tys. i od 20 do 100 tys. mieszkańców, choć ich spadek wystąpił we wszystkich typach miejscowości zamieszkania. Wskaźnik ten nie przekracza 26,8 proc. w miastach (29 proc. w 2009 r., 34 proc. w 2007 r.), zaś na wsi wynosi zaledwie 9 proc. (11,4 proc. w 2009 r., 8,5 proc. w 2007 r.). W tej grupie wieku nie zaobserwowano pogłębienia się różnic pomiędzy miastem a wsią, zmieniło się natomiast wzajemne relacje między wskaźnikami w miastach na niekorzyść miast od 20 tys. do 200 tys. mieszkańców. 
Tabela 4.5.1. Ludność w gospodarstwach domowych wedtug statusu edukacyjnego i miejsca zamieszkania (odsetek osób w danym wieku i miejscu zamieszkania korzystajacych z określonej usługi edukacyjnej), 2000-2011 (w proc.)

\begin{tabular}{|c|c|c|c|c|c|c|c|}
\hline \multirow[b]{2}{*}{ Status edukacyjny } & \multicolumn{6}{|c|}{ Klasa miejscowości zamieszkania } & \multirow[b]{2}{*}{ Ogółem } \\
\hline & $\begin{array}{l}\text { Miasta } \\
\text { powyżej } 500 \\
\text { tys. }\end{array}$ & $\begin{array}{l}\text { Miasta } \\
200-500 \\
\text { tys. }\end{array}$ & $\begin{array}{c}\text { Miasta } \\
100-200 \\
\text { tys. }\end{array}$ & $\begin{array}{l}\text { Miasta } \\
20-100 \\
\text { tys. }\end{array}$ & $\begin{array}{l}\text { Miasta } \\
\text { poniżej } 20 \\
\text { tys. }\end{array}$ & Wieś & \\
\hline \multirow{6}{*}{$\begin{array}{l}\text { Ogółem odsetek osób } \\
\text { korzystających z usług } \\
\text { edukacyjnych }\end{array}$} & $25,30^{6}$ & 25,70 & 24,50 & 22,30 & 24,00 & 24,20 & 24,10 \\
\hline & $26,60^{5}$ & 28,00 & 25,00 & 25,10 & 25,30 & 25,60 & 25,80 \\
\hline & $27,09^{4}$ & 27,26 & 27,59 & 25,17 & 27,26 & 26,61 & 26,60 \\
\hline & $28,20^{3}$ & 27,88 & 29,55 & 27,85 & 30,03 & 26,84 & 27,94 \\
\hline & $25,43^{2}$ & 23,78 & 26,73 & 23,97 & 25,76 & 22,22 & 23,91 \\
\hline & $27,02^{1}$ & 26,41 & 24,01 & 27,17 & 27,39 & 24,64 & 25,94 \\
\hline \multirow{6}{*}{$\begin{array}{l}\text { Dzieci w wieku } 0-6 \text { lat } \\
\text { korzystające ze żłobka lub } \\
\text { przedszkola }\end{array}$} & 47,90 & 37,90 & 30,90 & 30,00 & 32,80 & 20,00 & 29,10 \\
\hline & 31,50 & 32,10 & 27,00 & 21,70 & 23,00 & 12,60 & 20,50 \\
\hline & 25,92 & 25,19 & 22,80 & 22,39 & 18,40 & 12,09 & 18,75 \\
\hline & 24,17 & 31,23 & 20,46 & 32,12 & 20,84 & 10,78 & 19,77 \\
\hline & 19,13 & 19,52 & 20,42 & 19,93 & 12,18 & 7,74 & 13,51 \\
\hline & 31,16 & 22,33 & 14,51 & 33,71 & 27,34 & 12,58 & 21,40 \\
\hline \multirow{6}{*}{$\begin{array}{l}\text { Dzieci w wieku 7-15 lat uczące } \\
\text { się w szkołach }\end{array}$} & 91,60 & 90,00 & 87,50 & 88,70 & 92,20 & 91,60 & 90,70 \\
\hline & 88,00 & 89,00 & 93,50 & 91,40 & 92,20 & 89,90 & 90,50 \\
\hline & 96,37 & 97,41 & 97,36 & 99,03 & 96,98 & 98,75 & 98,15 \\
\hline & 92,80 & 91,95 & 92,64 & 95,97 & 95,55 & 93,22 & 93,92 \\
\hline & 76,74 & 77,07 & 81,36 & 78,27 & 79,88 & 80,14 & 79,23 \\
\hline & 99,41 & 98,74 & 99,17 & 98,79 & 98,17 & 97,89 & 98,48 \\
\hline \multirow{6}{*}{$\begin{array}{l}\text { Młodzież w wieku 16-19 lat } \\
\text { ucząca się w szkołach }\end{array}$} & 98,10 & 93,10 & 86,40 & 98,20 & 91,20 & 92,50 & 93,50 \\
\hline & 96,50 & 94,70 & 97,10 & 97,10 & 96,40 & 94,20 & 95,40 \\
\hline & 97,43 & 98,92 & 93,54 & 91,66 & 98,65 & 95,09 & 95,29 \\
\hline & 92,78 & 93,67 & 94,34 & 91,69 & 89,68 & 92,93 & 92,39 \\
\hline & 93,67 & 91,07 & 93,85 & 89,12 & 94,01 & 87,74 & 90,39 \\
\hline & 89,40 & 97,63 & 86,30 & 90,03 & 87,55 & 85,43 & 88,47 \\
\hline \multirow{6}{*}{$\begin{array}{l}\text { Osoby w wieku } 20-24 \text { lata } \\
\text { korzystające z usług } \\
\text { edukacyjnych świadczonych w } \\
\text { trybie szkolnym i } \\
\text { pozaszkolnym }\end{array}$} & 73,50 & 72,80 & 57,10 & 61,20 & 60,10 & 49,40 & 58,80 \\
\hline & 83,00 & 72,60 & 66,90 & 65,80 & 58,00 & 47,60 & 60,90 \\
\hline & 80,23 & 72,82 & 57,50 & 64,64 & 62,75 & 49,23 & 60,76 \\
\hline & 70,44 & 67,61 & 63,80 & 57,34 & 53,64 & 50,76 & 57,51 \\
\hline & 61,64 & 61,51 & 61,02 & 53,92 & 46,33 & 38,98 & 49,90 \\
\hline & 61,06 & 58,22 & 23,93 & 45,18 & 45,77 & 25,99 & 40,55 \\
\hline \multirow{6}{*}{$\begin{array}{l}\text { Osoby w wieku } 25-29 \text { lat } \\
\text { korzystające z usług } \\
\text { edukacyjnych świadczonych w } \\
\text { trybie szkolnym i } \\
\text { pozaszkolnym }\end{array}$} & 26,80 & 24,50 & 10,50 & 13,80 & 16,60 & 9,00 & 15,10 \\
\hline & 28,70 & 26,30 & 21,20 & 19,50 & 16,40 & 11,40 & 18,40 \\
\hline & 34,39 & 19,01 & 26,88 & 16,80 & 15,75 & 8,53 & 17,19 \\
\hline & 24,68 & 15,55 & 21,66 & 12,29 & 18,30 & 8,90 & 14,08 \\
\hline & 18,29 & 17,32 & 14,99 & 17,01 & 10,02 & 7,56 & 12,69 \\
\hline & 16,69 & 18,63 & 2,44 & 18,25 & 8,49 & 7,11 & 11,45 \\
\hline \multirow{6}{*}{$\begin{array}{l}\text { Osoby w wieku } 30-39 \text { lat } \\
\text { korzystające z usług } \\
\text { edukacyjnych świadczonych w } \\
\text { trybie szkolnym i } \\
\text { pozaszkolnym }\end{array}$} & 7,10 & 6,80 & 6,90 & 3,40 & 6,00 & 1,90 & 4,30 \\
\hline & 7,50 & 10,80 & 8,60 & 7,60 & 6,90 & 3,80 & 6,20 \\
\hline & 11,61 & 8,85 & 10,84 & 8,83 & 8,01 & 2,52 & 6,99 \\
\hline & 11,09 & 8,14 & 4,32 & 5,59 & 5,92 & 1,84 & 4,98 \\
\hline & 8,10 & 9,64 & 9,01 & 4,64 & 4,88 & 3,19 & 5,44 \\
\hline & 4,70 & 2,53 & 5,35 & 3,20 & 1,88 & 0,32 & 2,29 \\
\hline \multirow{6}{*}{$\begin{array}{l}\text { Osoby w wieku powyżej } 39 \text { lat } \\
\text { korzystające z usług } \\
\text { edukacyjnych świadczonych w } \\
\text { trybie szkolnym i } \\
\text { pozaszkolnym }\end{array}$} & 3,20 & 2,20 & 2,30 & 1,00 & 0,80 & 0,50 & 1,30 \\
\hline & 2,70 & 2,40 & 1,50 & 1,40 & 1,50 & 0,90 & 1,50 \\
\hline & 4,62 & 2,52 & 2,88 & 1,61 & 1,36 & 1,08 & 1,90 \\
\hline & 2,10 & 0,90 & 1,77 & 1,30 & 1,45 & 0,93 & 1,26 \\
\hline & 2,45 & 0,85 & 2,03 & 0,85 & 2,22 & 0,61 & 1,22 \\
\hline & 0,47 & 0,92 & 0,33 & 0,80 & 1,29 & 0,32 & 0,61 \\
\hline
\end{tabular}

W 2011 r. kobiety w wieku 25-29 lat nadal częściej niż mężczyźni w tym wieku korzystały z usług edukacyjnych (18,1 proc. kobiet w porównaniu z 13,4 proc. mężczyzn wobec 19 proc. kobiet i 17 proc. mężczyzn w 2009 r. i 2007 r.). Ta grupa wieku charakteryzuje się najwyższą płodnością kobiet, co może ograniczać aktywność edukacyjną kobiet oraz zmniejszać motywację mężczyzn do kontynuowania nauki na rzecz zwiększenia motywacji do podjęcia pracy. Dysproporcje terytorialne nieznaczne powiększyły się - odsetek mieszkanek wsi w wieku 25-29 
lat aktywnych edukacyjnie jest 2,75 razy niższy od najwyższego odsetka dla miast, który waha się od 14,1 proc. do 28,6 proc. W 2009 r. odsetek kobiet mieszkających na wsi, które były aktywne edukacyjnie był mniejszy 2,5krotnie, ale w 2007 r. ponad 4-krotnie od najwyższego odsetka dla miast. Dla mężczyzn dysproporcje miasto-wieś są także duże, choć niższe niż w poprzedniej rundzie badania - podobnie jak w 2009 r. jedynie 10,4 proc. mieszkańców wsi (9 proc. w 2007 r.) korzysta z usług edukacyjnych w trybie szkolnym lub pozaszkolnym wobec 7,8-28.9 proc. w miastach (17-26 proc. w 2009 r., 13-35 proc. w 2007 r.). Niekorzystnie wyróżniają się miasta średnie i małe, szczególnie w przypadku mężczyzn.

Różnice terytorialne aktywności edukacyjnej utrzymują się w następnej grupie wieku (30-39 lat). W celu zachowania porównywalnych liczebności próby w stosunku do wyżej omówionych grup wieku zdecydowano na łączne przedstawienie grup wieku 30-34 lata oraz 35-39 lat. Jednak decydujący wpływ na wartość podanych niżej wskaźników ma grupa wieku 30-34 lata. Osoby w wieku 30-39 lat ponad trzykrotnie rzadziej korzystają z różnego rodzaju usług edukacyjnych w porównaniu do osób w wieku 25-29 lat. Odsetek osób aktywnych edukacyjnie w tym wieku w 2011 r. zmniejszył się do poziomu 4,3 proc. (miasta od 3,4 proc. do 7,1 proc., wieś - 1,9 proc, w porównaniu z 6,2 proc. w 2009 r. (miasta od 7 proc. do 11 proc., wieś - 3,8 proc.), oraz z 7 proc. w 2007 r. (miasta od 8 proc. do 12 proc., wieś - 2,5 proc.), ale pozostał na wyższym poziomie niż obserwowany wcześniej). Odsetek kobiet aktywnych edukacyjnie w tej grupie wieku wyniósł 6,2 proc. w porównaniu z 7,7 proc. w 2009 r. i 2007 r. , natomiast dla mężczyzn 3,5 proc. (4,6 proc. w 2009 r., 4,3 proc. w 2007 r.). Blisko 3,4 proc. kobiet ze wsi w wieku 30-39 lat jest aktywnych edukacyjnie (3,9 proc. w 2009 r. oraz 3,3 proc. w 2007 r. ). w porównaniu z 1,1 proc. mężczyzn (1,8 proc. w 2009 r., 2 proc. w 2007 r.). Podobnie jak w poprzednich grupach wieku także i wśród osób w wieku 30-39 lat zmniejszyło się korzystanie z usług edukacyjnych - dotyczy to zarówno kobiet jak i mężczyzn niezależnie od miejsca zamieszkania. Szczególnie negatywnie wyróżniają się miasta od 20-100 tys. mieszkańców. Aktywność edukacyjna zanika wśród osób powyżej 39 lat.

Podsumowując, analiza aktywności edukacyjnej przeprowadzona odrębnie dla dorosłych kobiet i mężczyzn, rozpatrywanych także według wieku i miejsca zamieszkania, uwidacznia nie tylko ogólny spadek stopnia korzystania z usług edukacyjnych i wciąż wyraźnie większe aspiracje edukacyjne kobiet, ale także pokazuje dysproporcje terytorialne, nie tylko miedzy miastem a wsią, ale także pomiędzy miastami, ze szczególnie negatywnym obrazem miast średnich od 100 do 200 tys. mieszkańców oraz mniejszych od 20 do 100 tys. mieszkańców. Tak negatywnych tendencji nie zanotowano dla miast poniżej 20 tys. mieszkańców oraz wsi, co może się wiązać z większą dostępnością różnego typu programów i projektów oferowanych dla tych typów miejscowości np. w ramach Europejskiego Funduszu Społecznego.

\subsubsection{Formy aktywności edukacyjnej osób dorostych}

W 2011 r. aktywność edukacyjna osób w wieku 18 lat i więcej przyjmowała głównie formę nauki w szkołach lub uczelniach wyższych - 93,3 proc. (w porównaniu z 92 proc. w 2009 r., 87 proc. w 2007 r.), z czego 84,1 proc. stanowiły szkoły publiczne (w porównaniu z 83,6 proc. w 2009 r., 80 proc. w 2007 r.). Jest to związane ze strukturą wieku tej populacji. Około 72,8 proc. respondentów korzystających z usług edukacyjnych było w $2011 \mathrm{r}$. w wieku 18-24 lata (w porównaniu z 70,2 proc. w 2009 r., 74 proc. w 2007 r.), 12,7 proc. stanowiły osoby w wieku w wieku 25-29 lat (14 proc. w 2009 r., 11 proc. w 2007 r.), a zaledwie 7,2 proc. osoby w wieku 30-39 lat (8,7 proc. w 2009 r., 8 proc. w 2007 r.). Struktura wieku korzystających z usług edukacyjnych uległa zmianom w stosunku do 2009 r. wzrósł udział osób w grupie wieku 18-24 lata, natomiast spadł udział osób w wieku 25-29 lat i 30-39 lat, co jest przejawem selektywności procesu dokształcania się wśród dorosłych ze względu na wiek.

Wśród osób kształcących się w wieku powyżej 24 lat wzrasta znaczenie usług w trybie pozaszkolnym, organizowanych w formie kursów i szkoleń zarówno w pracy jak i poza nią, jednak nadal nie jest to znacząca forma usług - jedynie około 6,5 proc. osób w wieku 25-29 lat oraz 13,3 proc. osób w wieku 30-39 lat korzystało z tego sposobu dokształcania się (w 2009 r. odpowiednio 7,5 proc. i 31 proc., w 2007 r.). W porównaniu z wynikami poprzednich rund badania w grupie wieku 30-39 lat nastąpił znaczny spadek korzystania z kursów i szkoleń. Jest on znacznie większy niż ogólny spadek aktywności edukacyjnej $\mathrm{w}$ tej grupie wieku, co sugeruje przesuniecie się aktywności edukacyjnej w kierunku ofert szkół, a przede wszystkim uczelni wyższych. Znacznie niższy odsetek osób w wieku 25-29 lat korzystających z usług edukacyjnych w trybie pozaszkolnym w porównaniu z osobami w wieku 30-39 lat wynika, między innymi, z częstszego korzystania z ofert studiów podyplomowych w trybie szkolnym, generalnego rozwoju rynku usług w trybie szkolnym czy też lepszego przygotowania do wymagań rynku pracy (związanych np. z obsługą komputerów) przez osoby młodsze. Warto podkreślić, że 69 proc. osób korzystających z usług w trybie pozaszkolnym miało wykształcenie wyższe (53 proc. w 2009 r., 47 proc. w 2007 r.), a blisko 28 proc. - średnie i policealne (35 proc. w 2009 r., 32 proc. w 2007 r.). Pogłębił się zatem proces selektywności korzystania z usług edukacyjnych ze względu na poziom wykształcenia wśród osób powyżej 24 roku życia - dokształcają się w przeważającej części osoby z wykształceniem wyższym. Odwróceniu uległ trend z poprzednich rund badania polegający na zwiększeniu się udziału osób z wykształceniem średnim uczestniczących w kształceniu ustawicznym. 


\subsubsection{Korzystajacy z ustug edukacyjnych wedtug statusu na rynku pracy}

Analiza osób w wieku 18 lat i więcej, korzystających z usług edukacyjnych, rozpatrywanych według statusu na rynku pracy wskazuje, że zarówno w 2009 r. jak i 2011 r. około 60 proc. stanowią osoby bierne zawodowo, z których około 91 proc. w 2009 r. i 89 proc. w 2011 r. (w porównaniu z 95 proc. w 2007 r.) to osoby w wieku do 24 lat, znajdujące się jeszcze w systemie edukacji szkolnej. W grupie osób aktywnych zawodowo, które korzystały z usług edukacyjnych, jedynie 13,6 proc. stanowiły osoby bezrobotne, w porównaniu z 8,5 proc. w 2009 r. i 14 proc. w 2007 r. W procesie podnoszenia kwalifikacji wśród osób w wieku powyżej 24 lat uczestniczą głównie pracujący, którzy mają i tak stosunkowo wyższe kwalifikacje niż osoby bezrobotne czy bierne zawodowo. Zarówno wśród osób pracujących, jak i bezrobotnych powyżej 18 roku życia wykazujących aktywność edukacyjną najczęściej spotyka się kobiety, które stanowiły 65,5 proc. bezrobotnych oraz 58,2 proc. pracujących (w 2009 r. odpowiednio 54,5 proc. i 53,7 proc., w 2007 r. - 57 proc. i 58 proc.). Osoby aktywne zawodowo i edukacyjnie korzystały głównie z usług świadczonych w systemie szkolnym - 87,2 proc. bezrobotnych oraz 80,7 proc. pracujących (w 2009 r. odpowiednio 93 proc. i 78 proc., w 2007 r. 96,6 proc. i 80 proc.).

Istotną kwestią w analizie aktywności osób młodych w wieku 15-24 lata z punktu widzenia ich dalszych losów na rynku pracy jest odsetek osób niebędących w zatrudnieniu, ani niepodejmujących kształcenia w systemie szkolnym czy pozaszkolnym (ang. NEET - not in employment, education or training). W tabeli 4.5.2. zawarto informacje dotyczące odsetka osób biernych zawodowo i edukacyjnie w wieku 15-24 lata (ang. NEET) w latach 2000-2011.

W latach 2000-2005 odsetek osób biernych zawodowo i edukacyjnie utrzymywał się na stałym poziomie około 13 proc., w 2007 r. zmalał do około 10 proc. i ustabilizował się na poziomie około 9 proc. w latach 2009 r. i 2011 r. Miernik ten wykazywał tendencję spadkową dla kobiet przez cały analizowany okres, dla mężczyzn natomiast wyraźny spadek miał miejsce dopiero po 2005 r. Związane może to być z większą aktywnością edukacyjną kobiet, szczególnie w latach 2000-2005. Analizowany wskaźnik 'bierności ogólnej’ jest na ogół mniejszy dla kobiet niż mężczyzn, niższa aktywność zawodowa kobiet w tej grupie wieku jest rekompensowana ich wyższą aktywnością edukacyjną w porównaniu z mężczyznami. Rozkład wskaźnika NEET według miejsca zamieszkania wskazuje na różnice niekorzystne dla mieszkańców wsi, choć luka we wskaźniku w latach 2007-2011 uległa znacznemu zmniejszeniu.

Wartości wskaźnika NEET wyznaczone na podstawie danych Eurostatu także uwidaczniają jego tendencję spadkową w Polsce w rozpatrywanym okresie. Jego poziom sytuuje Polskę grupie krajów europejskich, w których NEET jest poniżej średniej UE-27, co jest głównie skutkiem relatywnie wysokiej skolaryzacji osób z tej grupy wieku.

Tabela 4.5.2. Osoby bierne zawodowo i edukacyjnie w wieku 15-24 lata wg płci i miejsca zamieszkania w latach 2000-2011 (w proc.)

\begin{tabular}{llllrrc}
\hline Miejsce zamieszkania/ płeć & 2000 & 2003 & 2005 & 2007 & 2009 & 2011 \\
\hline Ogółem & 12,7 & 12,8 & 12,6 & 10,4 & 8,6 & 8,7 \\
Kobiety & 14,7 & 11,8 & 11,9 & 10,7 & 7,8 & 8,2 \\
Mężczyźni & 11,3 & 13,8 & 13,3 & 10,1 & 9,4 & 9,2 \\
Miasto & 10,8 & 11,2 & 11,6 & 9,6 & 7,3 & 7,2 \\
Wieś & 16,0 & 15,3 & 14,5 & 11,5 & 8,6 & 8,7 \\
\hline
\end{tabular}

\subsubsection{Migracje edukacyjne}

Rozszerzenie Unii Europejskiej w maju 2004 roku zwiększyło szanse podejmowania studiów na zagranicznych uczelniach. Poniżej przedstawiona jest analiza migracji edukacyjnych - tych, które miały miejsce w latach 2005 2009 oraz 2007-2011, a ich uczestnicy wrócili do kraju. W kwestionariuszu Diagnozy Społecznej 2011, w przeciwieństwie do rundy z 2009 r., nie umieszczono pytań o zamierzenia w zakresie migracji edukacyjnych, w związku z tym analiza ogranicza się jedynie do migracji zrealizowanych w obu analizowanych okresach.

Ze względu na niewielką grupę respondentów, którzy wzięli udział w migracjach edukacyjnych w latach 2005 2009 ( $\mathrm{N}=157)$ oraz 2007-2011 ( $\mathrm{N}=107)$, analiza tego zjawiska jest ograniczona. Zaledwie 0,4 proc. członków gospodarstw domowych wyjeżdżało za granicę w latach 2007-2011 w celu podjęcia kształcenia, co jest wynikiem zbliżonym do okresu 2005-2009, kiedy wskaźnik ten wyniósł 0,5 proc. Zdecydowana większość osób wyjeżdżających za granicę w okresie 2007-2011 była w wieku 18-34 lata - około 67,3 proc. w porównaniu z 74 proc. w okresie 2005-2009, z czego aż około 62 proc. stanowią kobiety w obu porównywanych okresach. Udział kobiet, które wyemigrowały za granicę w celach edukacyjnych jest wyższy niż wynikałoby to z różnic wskaźnika skolaryzacji kobiet i mężczyzn w tej grupie wieku, co wskazuje na większą skłonność kobiet do podejmowania tego typu migracji. Ze względu na wysoką selektywność migracji edukacyjnych ze względu na wiek dalsza analiza dotyczy osób w wieku 18-34 lata. Odsetek osób, które wyjechały za granicę w celach edukacyjnych wśród populacji w wieku 18-34 lata wynosi zaledwie 0,8 proc. w okresie 2007-2011 w porównaniu z 1,2 proc. w latach 2005-2009, zaś wśród osób dokształcających się w tej grupie wieku 1,6 proc. w latach 2007-2011 w porównaniu z 2,2 proc. W okresie 2005-2009. Wynik taki świadczy o niezmiernie niskim poziomie migracji edukacyjnych, który dodatkowo 
obniżył się w ostatnim okresie. Wśród osób w wieku 18-34 lata, które podjęły naukę za granica, dominują mieszkańcy miast (około 83-85 proc. w obu analizowanych okresach), głównie największych (powyżej 500 tys. mieszkańców - około 39 proc. w okresie 2007-2011 i 29 proc. w okresie 2005-2009). Wśród migrantów w analizowanej grupie wieku przeważały osoby legitymujące się wykształceniem wyższym (około 72,4 proc. w latach 2007-2011 w porównaniu z 56 proc. w okresie 2005-2009) lub średnim (odpowiednio około 18,9 i 39 proc.). Tak duże różnice związane są z wprowadzeniem obowiązkowego poziomu licencjackiego na studiach wyższych, który kwalifikuje się jako wykształcenie wyższe. Wyniki te wskazują, że naukę za granica podejmowali studenci, a także absolwenci szkół wyższych. Migracje edukacyjne w rozpatrywanym okresie dla osób w wieku 18-34 lata miały głównie charakter jednorazowy (prawie 62-63 proc. wskazań w obu analizowanych okresach) i trwały głównie do pół roku (około 68,8 proc. w okresie 2007-2011 w porównaniu z około 54 proc. w latach 2005-2009). Ze względu na konstrukcję pytania w kwestionariuszu Diagnozy Społecznej 2009 i 2011 dotyczącego krajów docelowych migracji ujmującego łącznie migracje edukacyjne i zarobkowe, niewielka liczba osób migrujących w celach edukacyjnych uniemożliwia analizę rozkładu respondentów według miejsca docelowego migracji edukacyjnych.

Doświadczenia migracyjne dotyczące kształcenia wskazują na niewielkie znaczenie tego typu migracji. Wynikać to może $\mathrm{z}$ wielu przyczyn, jak np. koszty czy wciąż niewielkie rozpowszechnienie informacji o możliwościach wyjazdu. Migracje edukacyjne dotyczą właściwie wyłącznie ludzi młodych, głownie studentów, zamieszkujących duże aglomeracje miejskie, będące głównymi ośrodkami akademickimi. Aktywność edukacyjna za granicą jest łączona często z wykonywaniem pracy. Trudno stwierdzić natomiast, czy praca jest podejmowana, aby móc utrzymać się za granicą i studiować, czy raczej jako aktywność dodatkowa.

\subsubsection{Podsumowanie}

Uzyskane informacje o zakresie korzystania z usług edukacyjnych w badaniu z 2011 r. oraz zmian, jakie zaszły w okresie 2009-2011, można podsumować następująco:

- w 2011 r. w porównaniu z 2009 r. dostęp dzieci w wieku 0-6 lat do opieki instytucjonalnej znacznie zwiększył się, szczególnie na wsiach i miastach największych;

- $\quad$ występuje małe zróżnicowanie terytorialne dostępu do kształcenia się wśród dzieci i młodzieży w wieku 7 19 lat, sytuacja w miastach od 100 do 200 tys. mieszkańców pogorszyła się;

- zwiększenie aktywności edukacyjnej kobiet w wieku 20-24 lata na wsiach decyduje o kontynuacji ogólnej tendencji wzrostowej, która jednak uległa spowolnieniu. Natomiast utrzymujący się spadek aktywności edukacyjnej mężczyzn w tym wieku pogłębia lukę aktywności edukacyjnej pomiędzy kobietami i mężczyznami, szczególnie na wsiach i w największych miastach;

- aktywność edukacyjna dorosłych obniżyła się w porównaniu z poprzednią rundą badania, szczególnie niekorzystne zmiany dotyczą miast średnich od 20 do 200 tys.;

- ogólny nieznaczny spadek odsetka osób w wieku 20-24 lat w dużych i średnich miastach kontynuujących naukę i nieznaczny wzrost aktywności edukacyjnej mieszkańców wsi i małych miast przyczynia się do zmniejszenia wciąż znacznych różnic przestrzennych w korzystaniu z usług edukacyjnych;

- $\quad$ ogólny spadek udziału korzystających z usług edukacyjnych wśród osób w wieku 25-29 lat wynika przede wszystkim ze znacznego zmniejszenia aktywności edukacyjnej mieszkańców miast od 20 do 200 tys. mieszkańców. Różnice terytorialne w aktywności edukacyjnej w tej grupie wieku utrzymały;

- niska aktywność edukacyjna osób w wieku 30-39 lat uległa dalszemu pogorszeniu;

- utrzymuje się brak skłonności do korzystania z usług edukacyjnych osób w wieku powyżej 39 lat.

- nadal proces doskonalenia kwalifikacji osób dorosłych jest selektywny z względu na wiek, płeć, miejsce zamieszkania, wykształcenie oraz status na rynku pracy.

Wyniki kolejnych rund Diagnozy Społecznej wskazują, że kształcenie ustawiczne osób dorosłych, uznawane za jeden z podstawowych warunków zwiększenia zdolności do zatrudnienia, ma w Polsce wciąż zakres marginalny, a pozytywne tendencje zaobserwowane w 2009 r. w tym zakresie uległy w znacznej mierze odwróceniu. Jest to sygnał niepokojący, bowiem zestawienie wyników dotyczących aktywności edukacyjnej dorosłej ludności Polski ze strukturą ludności według poziomu wykształcenia i umiejętnościami cywilizacyjnymi, określonymi w początkowych rozdziałach opracowania i miejscem zamieszkania, obrazuje dysproporcje dotyczące szans rozwojowych mieszkańców miast i wsi, a także generalnie osób w wieku 35 lat i więcej, a zwłaszcza osób w wieku niemobilnym. Różnice poziomu wykształcenia i znajomości języków czy obsługi komputera między osobami młodymi i osobami w wieku 35 lat i więcej wskazują na lukę kompetencyjną, która pogłębia się w miarę przechodzenia do starszych grup wieku. Potwierdzają to analizy odwołujące się do syntetycznego miernika kapitału ludzkiego według wieku (por. rozdz. 4.5.2).

Rozpiętość między zapotrzebowaniem na usługi edukacyjne, wynikające $\mathrm{z}$ istniejącego poziomu wykształcenia i kwalifikacji ludności - z jednej strony oraz przemian technologicznych i wymagań dotyczących zasobów pracy - z drugiej strony, a przedstawionym wyżej wzorcem aktywności edukacyjnej wyróżnionych grup ludności świadczy o pilnej konieczności intensyfikacji procesu kształcenia ustawicznego w Polsce. Niezbędny jest rozwój różnych form uzupełniania wykształcenia i podnoszenia kwalifikacji (nauka w trybie wieczorowym, zaocznym czy 
korespondencyjnym, studia podyplomowe, kursy i szkolenia) oraz działania na rzecz wzrostu zakresu korzystania z usług edukacyjnych. Dotyczy to w szczególności osób w wieku niemobilnym.

Zestawienie tych wyników ze spostrzeżeniem o słabym przygotowaniu osób w wieku niemobilnym do funkcjonowania we współczesnym społeczeństwie i na współczesnym rynku pracy za względu na poziom ich kapitału ludzkiego, prowadzi do wniosku, iż zatrzymanie tej grupy osób na rynku pracy wymaga specjalnych działań skierowanych na zwiększenie ich zdolności do zatrudnienia. Polska ma najniższe w Unii Europejskiej wskaźniki zatrudnienia osób w wieku 55-64 lata. Bez wzrostu kapitału ludzkiego tych osób postulowany wzrost ich zatrudnienia jest nierealny, a zagrożenie bezrobociem i biernością będzie wzrastać, nawet w okresach stosunkowo dobrej koniunktury.

\subsubsection{Kapitał ludzki}

Dorota Węziak-Białowolska, Irena E. Kotowska

Rozwój gospodarki opartej na wiedzy i społeczeństwa informacyjnego sprawia, że - niezależnie od definiowania tych pojęć i ich interpretacji - w dyskusji o uwarunkowaniach współczesnych procesów rozwojowych nastąpiło przeniesienie akcentów z zasobów materialnych na zasoby niematerialne (por. np. Drucker, 1999; Kukliński, 2004; Zacher, 1999; OECD, 1998). Są one często utożsamiane z zasobami intelektualnymi. Najważniejszym ich elementem jest kapitał ludzki, któremu przypisuje się też największy potencjał wzrostu. Wielkość i produktywność zasobów intelektualnych jest niezwykle trudna do pomiaru i oceny. Jednak bez prób pomiaru nie można analizować zarówno przebiegu procesów rozwoju w przeszłości, jak i oceniać możliwości rozwojowych poszczególnych krajów lub regionów.

W obecnej edycji Diagnozy, podobnie jak w latach 2007 oraz 2009, dokonano pomiaru kapitału ludzkiego Polaków, rozumianego podobnie jak poprzednio jako zasób wiedzy, umiejętności i kwalifikacji poszczególnych osób, grup osób i całego społeczeństwa, określający ich zdolności do pracy, przystosowania do zachodzących zmian i kreatywność. Analiza dotyczy poziomu kapitału ludzkiego oraz jego zróżnicowania według wybranych charakterystyk demograficznych, ekonomicznych i społecznych. Pozwala to na ocenę różnic wyposażenia w kapitał ludzki różnych społeczno-ekonomicznych grup ludności, jak również porównanie zmian w poziomie kapitału ludzkiego między kolejnymi edycjami Diagnozy Społecznej. W celu umożliwienia porównań w czasie zastosowano identyczną jak w latach poprzednich metodę pomiaru.

\subsubsection{Pomiar kapitału ludzkiego}

Na podstawie danych Diagnozy Społecznej z lat 2007, 2009 oraz 2011 dokonano pomiaru kapitału ludzkiego na podstawie następującej procedury:

- sformułowano model teoretyczny kapitału ludzkiego - definicja kapitału ludzkiego,

- sformułowano model pomiarowy kapitału ludzkiego - wybór zmiennych wskaźnikowych,

- $\quad$ za pomocą eksploracyjnej i konfirmacyjnej analizy czynnikowej sprawdzono poprawność modelu pomiarowego,

- za pomocą analizy głównych składowych dla zmiennych jakościowych (CATPCA) stworzono syntetyczny wskaźnik kapitału ludzkiego.

Metody zastosowane w etapie 3 i 4 tej procedury opisano bliżej w Aneksie, tutaj odwołamy się do niektórych wyników zastosowanej metody pomiaru kapitału ludzkiego.

Syntetyczny wskaźnik kapitału ludzkiego został obliczony dla odpowiednich grup ludności wyłonionych na podstawie cech demograficznych, społecznych i ekonomicznych. Porównanie zmian w czasie wartości tego miernika dla różnych grup ludności pozwala na ocenę ich relatywnej sytuacji oraz jej zmian w czasie.

Podobnie jak w latach poprzednich do pomiaru kapitału ludzkiego na podstawie Diagnozy Społecznej 2011 posłużono się informacjami o wykształceniu respondentów w wieku 16 lat i więcej, ich kompetencjach cywilizacyjnych oraz uczestnictwie w kształceniu ustawicznym i dokształcaniu zmierzających do podnoszenia kwalifikacji zawodowych lub innych umiejętności. Tak jak w roku 2009 poziom wykształcenia był mierzony liczba lat nauki, co pozwoliło na uzyskanie większej precyzji wyników.

Wybór zmiennych wskaźnikowych wynikał z przyjętej definicji kapitału ludzkiego. Definicja ta jeszcze kilkanaście lat temu obejmowała głównie poziom wykształcenia ludzi, obecnie jednak uległa znacznemu rozszerzeniu. Pojawienie się społeczeństwa informacyjnego i gospodarki opartej na wiedzy pociagga za sobą konieczność stałego rozszerzania i aktualizacji zdobytej wiedzy, umiejętności i kompetencji. Nie tylko sprostanie wymaganiom współczesnego rynku pracy, ale także funkcjonowanie w społeczeństwie i przystosowanie się do zachodzących zmian wiąże się z posiadaniem innych umiejętności niż kilkanaście lat temu i koniecznością stałego ich uzupełniania. Należą do nich między innymi:

- znajomość technologii informacyjno-komunikacyjnych (ICT),

- umiejętność pozyskiwania i wykorzystywania informacji ze źródeł elektronicznych,

- szybkie komunikowanie się, 
- znajomość języków obcych, a zwłaszcza języka angielskiego, będącego głównym językiem Internetu i nauki.

Oprócz tego istotna jest świadomość konieczności ciąłego poszerzania i aktualizowania swojej wiedzy i umiejętności poprzez podejmowanie odpowiednich działań edukacyjnych.

Te przesłanki kierowały wyborem zmiennych wskaźnikowych do pomiaru kapitału ludzkiego na podstawie danych Diagnozy Społecznej 2011. Skorzystano zatem z następujących zmiennych:

- $\quad$ wykształcenie - mierzone liczbą lat nauki [liczba lat nauki] ${ }^{30}$,

- $\quad$ kompetencje cywilizacyjne - przyjęto, że przejawiają się one poprzez:

- korzystanie z komputera w pracy, w domu lub w innym miejscu [komputer],

- korzystanie z wyszukiwarki internetowej (np. Google, Yahoo!) w celu znalezienia informacji [wyszukiwarka],

- $\quad$ znajomość języka angielskiego [angielski];

- uczestnictwo w kształceniu ustawicznym i dokształcaniu - pomiaru dokonano na podstawie odpowiedzi na pytanie o podnoszenie kwalifikacji zawodowych lub innych umiejętności w ciagu ostatnich 2 lat [szkolenia];

Zmienne definiujące kapitał ludzki występują w charakterze jego stymulant, co oznacza, że ich wyższe wartości są utożsamiane z wyższym poziomem kapitału ludzkiego.

Jakość modelu pomiarowego kapitału ludzkiego sprawdzono stosując konfirmacyjną analizę czynnikową dla każdej rundy badania osobno oraz na połączonym zbiorze danych. W tym drugim przypadku estymowano model z narzuconymi warunkami równości na wszystkie ładunki czynnikowe, wyraz wolny dla zmiennej [liczba lat nauki] oraz na progi skal odpowiedzi dla pozostałych czterech zmiennych wskaźnikowych.

Uzyskane wyniki potwierdziły, że o poziomie kapitału ludzkiego decydują umiejętności cywilizacyjne, a nie tylko poziom wykształcenia i dokształcanie, choć znaczenia tych dwóch ostatnich nie można bagatelizować.

Do wyznaczenia syntetycznego miernika kapitału ludzkiego zastosowano analizę głównych składowych dla zmiennych jakościowych $^{31}$ (ang. Categorical Principal Component Analysis - CATPCA) - ze względu na jakościowy charakter czterech z pięciu zmiennych wskaźnikowych. Aby możliwe było porównanie poziomów kapitału ludzkiego w latach 2007, 2009 oraz 2011, analizę wykonano na połączonych zbiorach danych z Diagnozy Społecznej 2007, 2009 oraz 2011.

Potwierdzono, że zestaw zmiennych zaproponowanych do zmierzenia kapitału ludzkiego może dobrze diagnozować ukrytą zmienną kapitał ludzki. Okazało się, że dla trzech rund łącznie pięć zmiennych wskaźnikowych daje się zastąpić jedną zmienną syntetyczną, która w 54,42 proc. odtwarza zróżnicowanie zestawu zmiennych wskaźnikowych. Ponadto pierwsza główna składowa może być uznana za syntetyczny wskaźnik kapitału ludzkiego. W celu lepszego pokazania różnic w poziomie kapitału ludzkiego, jego syntetyczny wskaźnik, będący wielkością wystandaryzowaną (o średniej równej 0 i odchyleniu standardowym równym 1), znormalizowano tak, aby przyjmował wartości $\mathrm{z}$ przedziału $0-100^{32}$. Wszystkie analizy porównawcze prowadzono na zmiennej znormalizowanej.

\subsubsection{Kapitał ludzki społeczeństwa polskiego w latach 2007-2011}

Kapitał ludzki Polaków wzrasta systematycznie od roku 2007. W roku 2007 wskaźnik tego zasobu był na poziomie 45,2, w roku 2009 wyniósł 46,17, zaś w roku 2011 - 46,67 (wykres 4.5.1).

Wynik ten jest zgodny z wnioskami płynącymi z analizy dynamiki wartości poszczególnych zmiennych wskaźnikowych w latach 2007-2011 (wykres 4.5.2). W tym okresie wzrosły znacznie odsetki osób używających wyszukiwarki internetowej i używających komputera. Natomiast odsetek osób uczestniczących w aktywności związanej z podnoszeniem kwalifikacji lub umiejętności najpierw wzrósł (w roku 2009 w stosunku do roku 2007), a następnie zmniejszył się (w roku 2011 w stosunku do roku 2009). Udział osób znających język angielski (czynnie lub biernie) był stabilny.

\footnotetext{
${ }^{30} \mathrm{~W}$ nawiasach kwadratowych podano skrótowe nazwy zmiennych; nazwy te wykorzystywane są w dalszej części tekstu.

31 Jak podaje Górniak (2000 s.316), analiza głównych składowych w przeciwieństwie do analizy czynnikowej pozwala na jednoznaczne wyliczenie wartości zmiennych reprezentujących wymiary mierzone przez zestaw zmiennych wskaźnikowych.

${ }^{32}$ Wartościom 0 i 100 przypisano wartości nieznormalizowanego wskaźnika kapitału ludzkiego odpowiadające wartościom minimalnym i maksymalnym zmiennych wskaźnikowych; w przypadku liczby lat nauki za wartość min przyjęto 0 , a max = 30;
} 


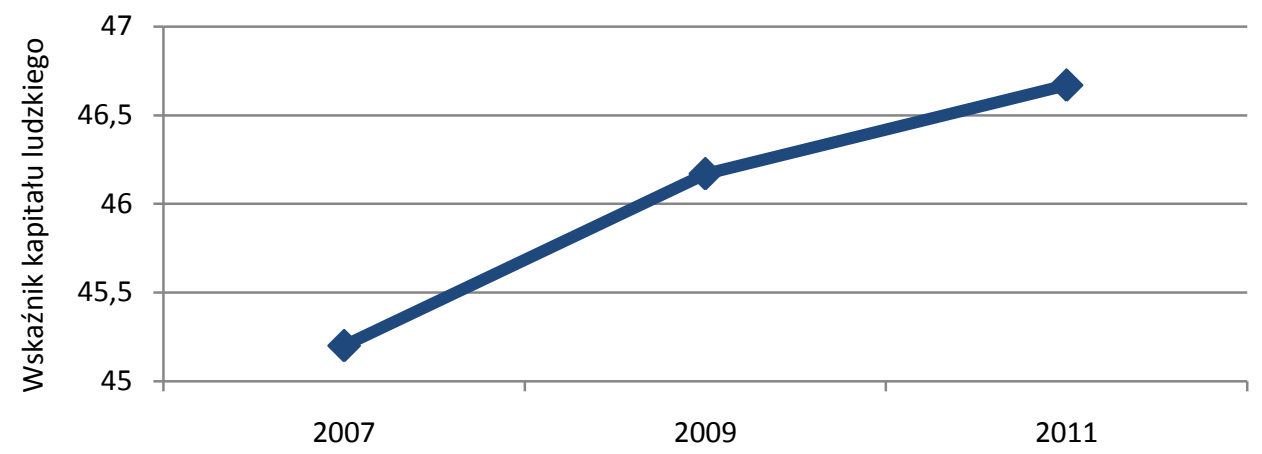

Wykres 4.5.1. Kapitat ludzki w latach 2007, 2009 i 2011.

Wynik ten jest zgodny $\mathrm{z}$ wnioskami płynącymi z analizy dynamiki wartości poszczególnych zmiennych wskaźnikowych w latach 2007-2011 (wykres 4.5.2). W tym okresie wzrosły znacznie odsetki osób używających wyszukiwarki internetowej i używających komputera. Natomiast odsetek osób uczestniczących w aktywności związanej z podnoszeniem kwalifikacji lub umiejętności najpierw wzrósł (w roku 2009 w stosunku do roku 2007), a następnie zmniejszył się (w roku 2011 w stosunku do roku 2009). Udział osób znających język angielski (czynnie lub biernie) był stabilny.

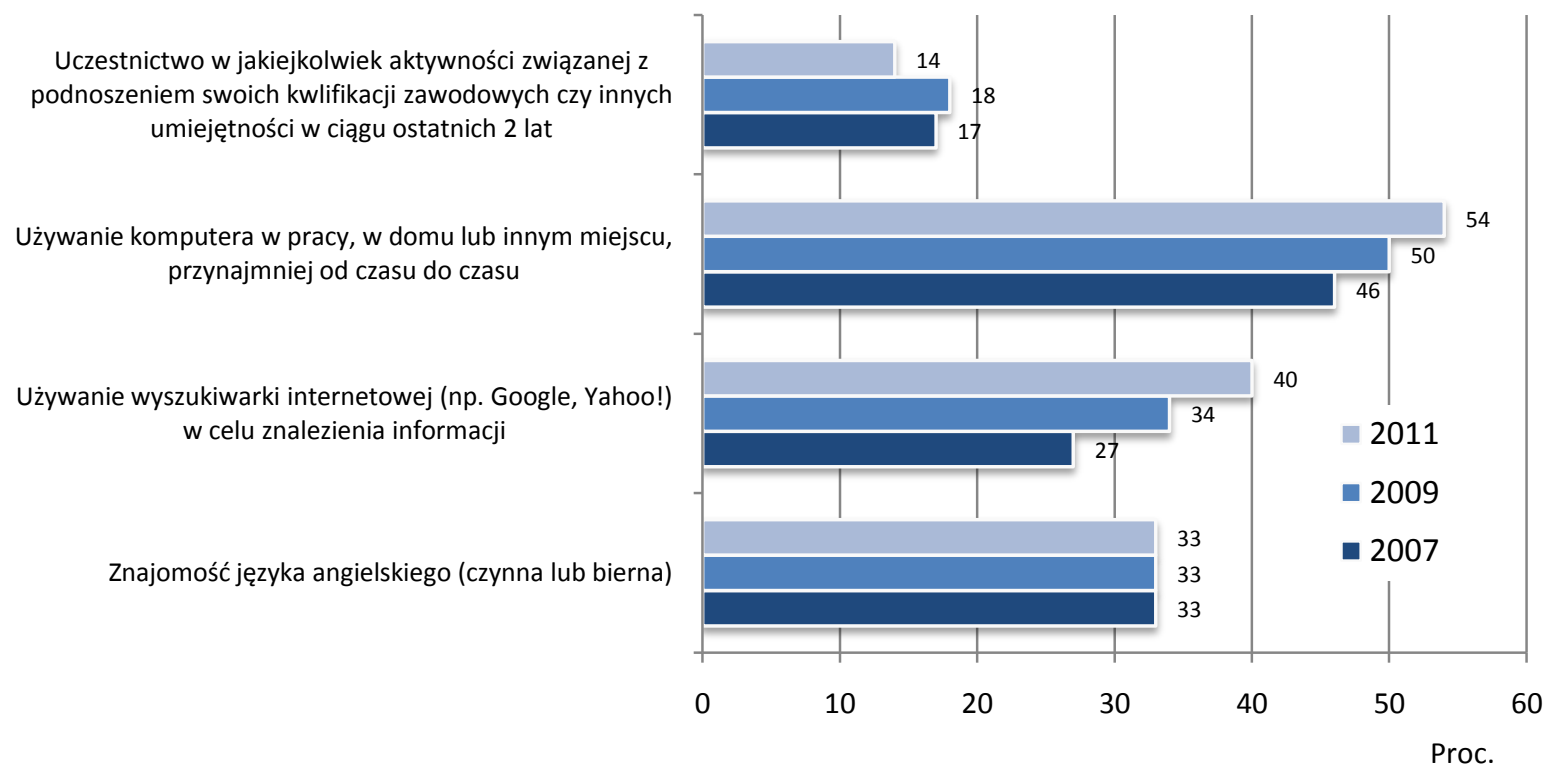

UWAGI: Odsetek osób używających wyszukiwarki internetowej wyrażono w stosunku do wszystkich badanych.

Wykres 4.5.2. Odsetek osób znajacych język angielski (czynnie lub biernie), używajacych wyszukiwarki internetowej $w$ celu znalezienia informacji, użyajacych komputera $w$ pracy lub innym miejscu, uczestniczacych $w$ jakiejkolwiek aktywności zwiqzanej z podnoszeniem swoich kwalifikacji zawodowych czy innych umiejętności w ciagu ostatnich dwóch lat.

Zmiany te są zapewne następstwem coraz większej informatyzacji życia społeczno-gospodarczego w Polsce, a także konsekwencją wchodzenia na rynek pracy osób, które od pierwszych klas szkoły podstawowej miały stały dostęp do komputera $\mathrm{w}$ domu. Nie bez znaczenia jest również bardzo dynamiczny rozwój narzędzi informatycznych, które pozwalają bardziej efektywnie znajdować informacje w sieci, a także zwiększenie dostępności profesjonalnego oprogramowania dedykowanego do pewnych typów działalności gospodarczej.

Wyniki wskazują, że większa dostępność technologii znajduje odzwierciedlenie w większym ich wykorzystaniu. Związany z tym rozwój kapitału ludzkiego będzie sprzyjać zmniejszaniu się luki między Polską a krajami Unii Europejskiej o wysokim poziomie kapitału ludzkiego. 


\subsubsection{Zróżnicowanie kapitału ludzkiego według grup społeczno-ekonomicznych}

Do oceny wyposażenia Polaków w kapitał ludzki w roku 2011 wykorzystano przeciętny poziom tego zasobu wyznaczony dla grup ludności wyróżnionych ze względu na:

- płeć,

- wiek,

- wielkości miejscowości zamieszkania

- $\quad$ status na rynku pracy,

- $\quad$ status społeczno-zawodowego.

Wyniki obliczeń zawierają tabele 4.5.1-4.5.3 oraz wykresy 4.5.3-4.5.7. Porównania wartości poziomu przeciętnego kapitału dla poszczególnych grup demograficzno-społecznych prowadzą do następujących spostrzeżeń:

- $\quad$ od 2009 roku mężczyźni cechowali się wyższym kapitałem ludzkim niż kobiety;

- $\quad$ kapitał ludzki malał wraz z wiekiem - najwyższym poziomem tego zasobu charakteryzowały się osoby w wieku 15-34 lata, zaś najniższym - osoby w wieku 45 lat i więcej; z czasem wzrasta różnica między osobami w wieku niemobilnym oraz osobami w wieku 35-44 lat, które zmniejszyły swój dystans do osób najmłodszych;

- kapitał ludzki malał wraz ze zmniejszaniem się wielkości miejscowości zamieszkania, zatem najlepiej wyposażeni w kapitał ludzki byli mieszkańcy największych miast, zaś najsłabiej - mieszkańcy wsi, choć relatywnie to oni wykazywali najwyraźniejszą poprawę poziomu kapitału; tendencja wzrostowa dotyczyła także mieszkańców innych klas miejscowości z wyjątkiem miast liczących od 100-200 tys. mieszkańców;

- osoby aktywne zawodowo były lepiej wyposażone w kapitał ludzki niż osoby bierne zawodowo, przy czym wśród osób aktywnych zawodowo wyższy kapitał ludzki miały osoby pracujące; zwiększył się dystans między osobami aktywnymi oraz biernymi zawodowo; na podkreślenie zasługuje znaczna poprawa poziomu kapitału ludzkiego wśród bezrobotnych w okresie 2009-2011, co przyczyniło się do wyraźnego zmniejszenia się różnicy między pracującymi i bezrobotnymi w wyposażeniu w kapitał ludzki;

- $\quad$ utrzymują się cztery wyraźne grupy osób wyróżnionych ze względu na status na rynku pracy i poziom kapitału: najwyższy poziom charakteryzuje studentów, druga grupę tworzą: pracownicy sektora publicznego, prywatni przedsiębiorcy oraz pracownicy sektora prywatnego, wymieniani według malejących wartości miernika, trzecia grupa o znacznie mniejszym poziomie kapitału to bezrobotni oraz inni bierni zawodowo, zaś emeryci i renciści tworzą grupę najsłabiej wyposażoną w ten zasób; relatywna poprawa poziomu kapitału dotyczy przede wszystkim grupy bezrobotnych i innych biernych zawodowo, a następnie - choć znacznie słabsza - rolników.

Jeszcze w 2007 roku nie było żadnej różnicy w poziomie kapitału ludzkiego między mężczyznami i kobietami. Różnica taka pojawiła się w 2009 r. i pozostała do 2011 r.

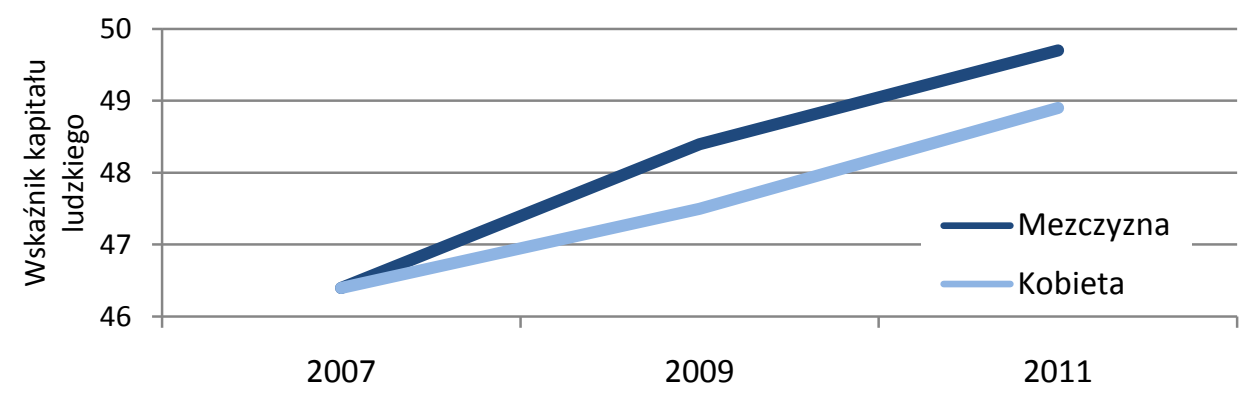

Wykres 4.5.3. Przeciętny poziom kapitału ludzkiego w latach 2007-2011wedtug płci

Malejący bardzo dynamicznie wraz z wiekiem poziom kapitału ludzkiego wydaje się być znakiem współczesnych czasów. Technologie, które są wykorzystywane i uznawane za nowoczesne, mają bardzo krótką historię. W przeszłości człowiek miał dużo więcej czasu na opanowanie umiejętności, które pozostawały w użyciu przez znaczną część jego życia. W gospodarce opartej na wiedzy pozycja jednostki na rynku pracy i jej konkurencyjność, a także sprawne funkcjonowanie w społeczeństwie jest determinowane przez zdolność i chęć do szybkiego przyswajania nowoczesnych technologii, w tym informacji i ich umiejętnego używania. Z tymi wyzwaniami cywilizacyjnymi lepiej radzą sobie ludzie młodzi - stąd najwyższy poziom kapitału ludzkiego w grupach wieku 15-34 lata. 


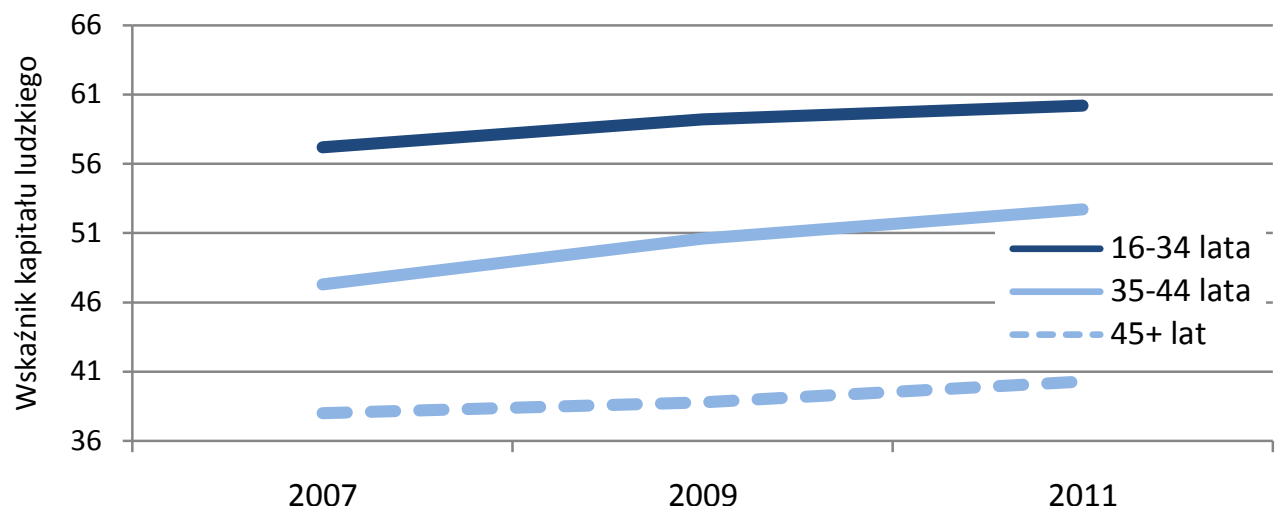

Wykres 4.5.4. Przeciętny poziom kapitału ludzkiego w latach 2007-2011 wedtug wieku

Zmniejszanie się kapitału ludzkiego wraz ze zmniejszaniem się klasy miejscowości zamieszkania jest powodowane kilkoma czynnikami. Po pierwsze, duże miasta dysponują o wiele lepszą bazą edukacyjną. Wszystkie miasta powyżej 500 tys. mieszkańców są ośrodkami akademickimi ze zgromadzonym bardzo znaczącym zasobem kapitału ludzkiego. Posiadają również najlepsze szkoły średnie, a często i podstawowe. Oferują one o wiele lepszą infrastrukturę dla uczniów i studentów, zapewniając chociażby dostęp do bibliotek i miejsc, w których można korzystać z najnowocześniejszych technologii. Po drugie, do dużych miast migrują osoby najlepiej wykształcone, gdyż są one dzięki zgromadzonemu kapitałowi ludzkiemu o wiele bardziej mobilne oraz są w stanie uzyskać lepsze oferty pracy. Po czwarte, w dużych miastach lokalizują swoje siedziby duże przedsiębiorstwa, które zatrudniają pracowników o wyższych kwalifikacjach i przyciagają osoby z wyższym kapitałem ludzkim.

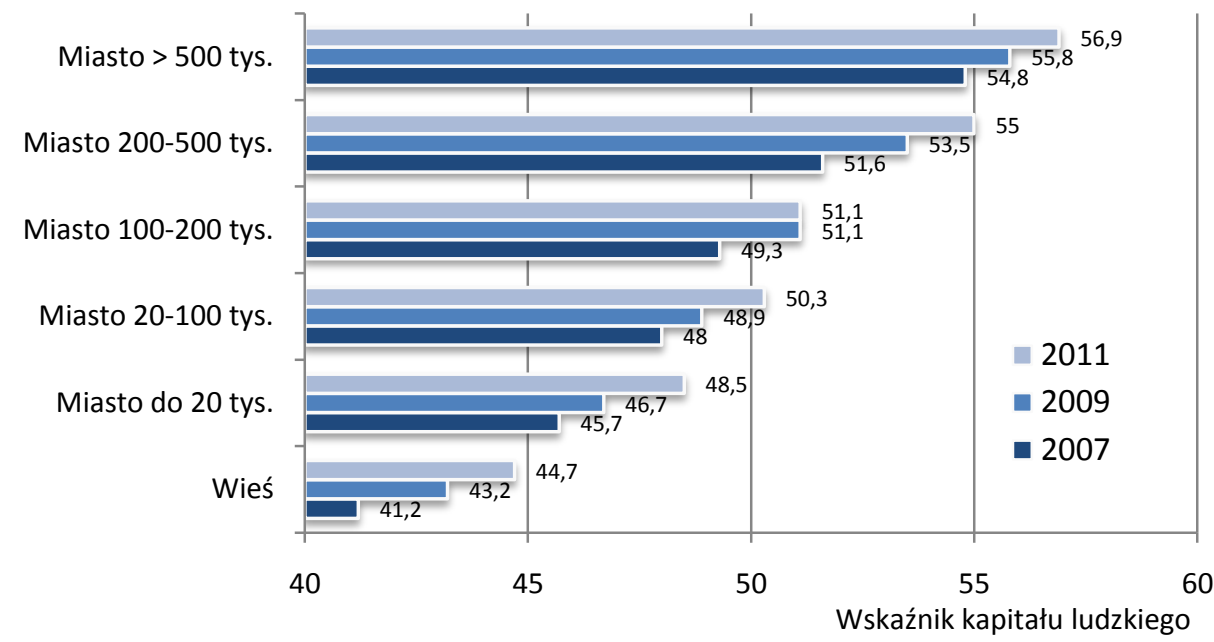

Wykres 4.5.5. Przeciętny poziom kapitału ludzkiego w latach 2007-2011 według klasy miejscowości zamieszkania

Aktywność zawodowa sprzyja podtrzymywaniu poziomu kapitału ludzkiego, a także zdobywaniu nowych umiejętności. Pozostawanie poza rynkiem pracy prowadzi na ogół do stopniowej deprecjacji posiadanych kwalifikacji i umiejętności i przyczynia się do obniżenia kapitału, co z kolei może być przeszkodą w wyjściu z bierności zawodowej.

Aby dokładniej przyjrzeć się wyposażeniu Polaków w kapitał ludzki, sprawdzono, jak kształtował się poziom kapitału ludzkiego przy jednoczesnym uwzględnieniu płci oraz jednej z poniższych cech:

- wiek,

- wielkość miejscowości zamieszkania,

- $\quad$ status społeczno-zawodowy,

- $\quad$ status na rynku pracy.

Wyniki zestawiono w tabeli 4.5.1 (płeć) oraz tabeli 4.5.2 (pozostałe trzy cechy). Miernik syntetyczny kapitału ludzkiego wskazuje, iż w latach 2009 oraz 2011 mężczyźni są lepiej wyposażeni w kapitał ludzki (tabela 1). Jednak uwzględnienie wieku pozwoliło skorygować ten wniosek (tabela 2). We wszystkich analizowanych latach tj. w roku 2007, 2009 jak i 2011 wśród osób w wieku 15-34 lata i 35-44 lata to kobiety charakteryzowały się wyższym poziomem kapitału ludzkiego, natomiast wśród osób w wieku 45 lat i więcej - byli to mężczyźni. Zaobserwowane różnice między kobietami i mężczyznami dla grupy wieku 15-34 lata oraz 45 i więcej lat były statystycznie istotne 
we wszystkich analizowanych okresach ${ }^{33}$, zaś dla grupy wieku 35-44 lata były statystycznie istotne tylko w roku $2011^{34}$.

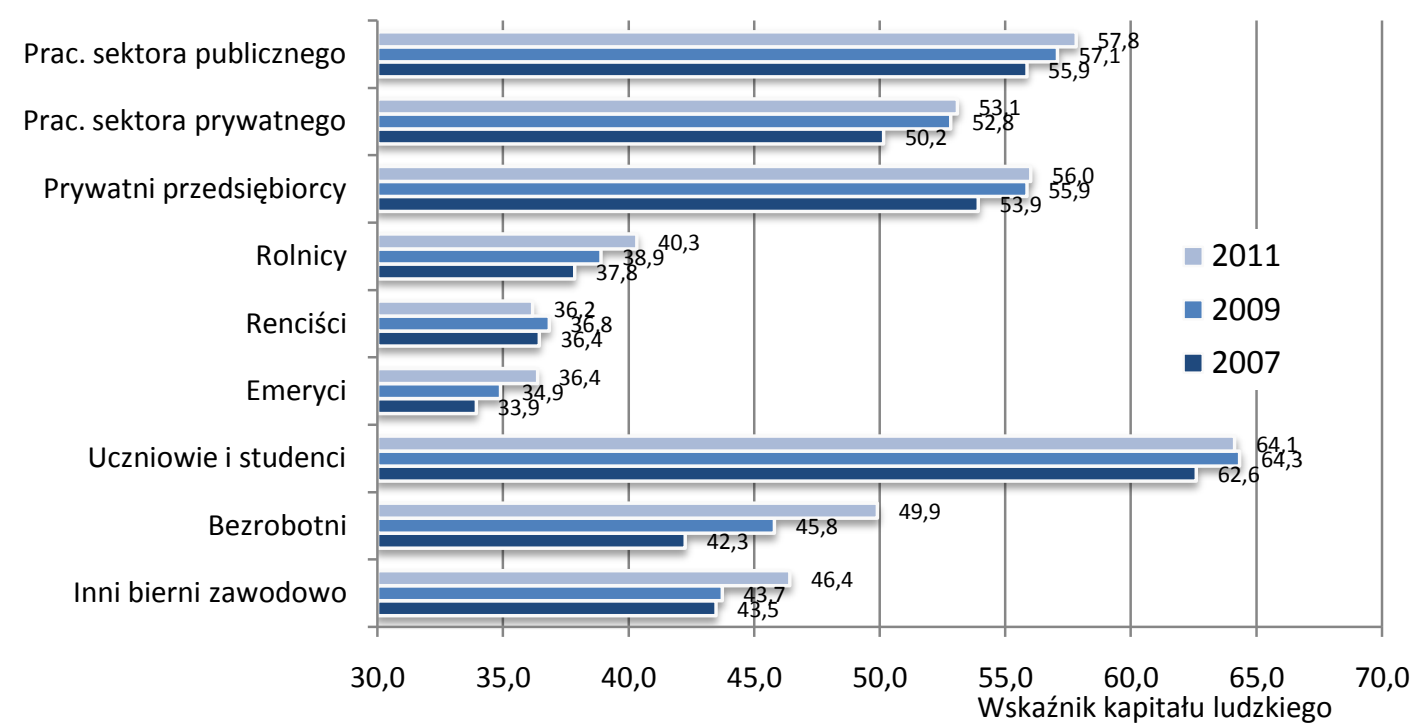

Wykres 4.5.6. Przeciętny poziom kapitału ludzkiego w latach 2007-2011 wedtug statusu społeczno-zawodowego

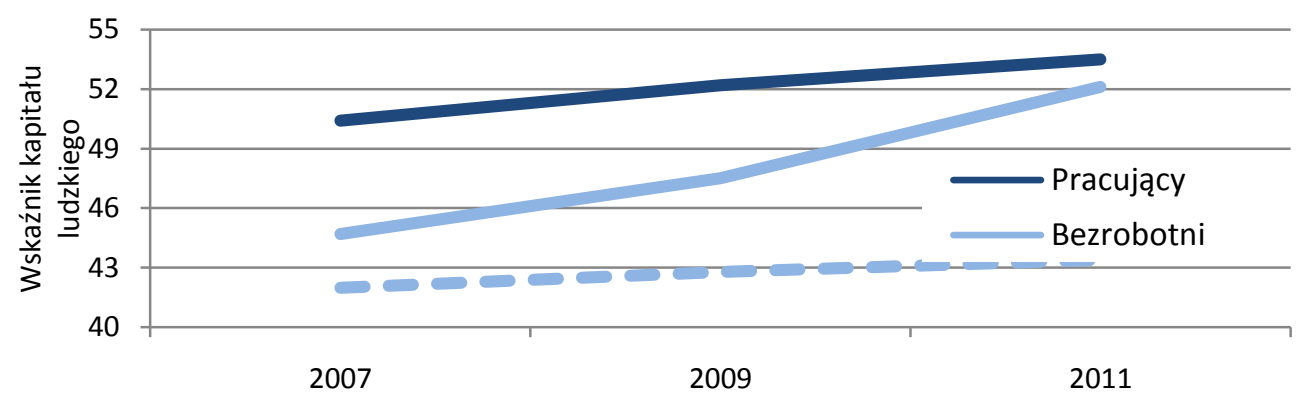

Wykres 4.5.7. Przeciętny poziom kapitalu ludzkiego w latach 2007-2011 wedtug statusu na rynku pracy

Wyższy poziom kapitału ludzkiego kobiet w wieku 15-44 lata jest zapewne konsekwencją większej liczby lat spędzonych przez nie na nauce formalnej oraz większego wskaźnika skolaryzacji na poziomie uniwersyteckim. Wyższy poziom kapitału ludzkiego mężczyzn w wieku 45 lat i więcej w porównaniu do kobiet może wynikać zarówno z niekorzystnych dla kobiet różnic wykształcenia w starszych grupach wieku, jak i z tego, że kobiety wcześniej niż mężczyźni wycofują się z rynku pracy. Tracą więc relatywnie wcześniej kontakt z innowacjami, korzystanie z których najczęściej wymusza rynek pracy.

Tabela 4.5.1. Poziom kapitału ludzkiego wedtug płci i wieku.

\begin{tabular}{clcccccc}
\hline \multirow{2}{*}{$\begin{array}{c}\text { Grupa } \\
\text { wieku }\end{array}$} & \multirow{2}{*}{ Płeć } & \multicolumn{2}{c}{ Kapitał ludzki w 2007 } & \multicolumn{2}{c}{ Kapitał ludzki w 2009 } & \multicolumn{2}{c}{ Kapitał ludzki w 2011 } \\
\cline { 3 - 7 } & & Średnia & Błąd standardowy & Średnia & Błąd standardowy & Srednia & Błąd standardowy \\
\hline \multirow{2}{*}{$15-34$} & mężczyzna & 56,03 & 0,29 & 58,25 & 0,18 & 59,28 & 0,16 \\
& kobieta & 58,15 & 0,26 & 60,08 & 0,17 & 61,20 & 0,15 \\
\multirow{2}{*}{$35-44$} & mężczyzna & 46,91 & 0,46 & 50,34 & 0,31 & 52,13 & 0,30 \\
& kobieta & 47,60 & 0,45 & 50,93 & 0,32 & 53,32 & 0,30 \\
\multirow{2}{*}{45 i wiecej } & mężczyzna & 38,27 & 0,24 & 39,42 & 0,17 & 41,07 & 0,17 \\
& kobieta & 37,71 & 0,22 & 38,28 & 0,15 & 39,76 & 0,15 \\
\hline
\end{tabular}

Wśród mieszkańców poszczególnych klas miejscowości we wszystkich analizowanych okresach bez względu na wielkość miejscowości zamieszkania wyższy poziom kapitału ludzkiego cechował mężczyzn. Jedynym odstępstwem był rok 2007, w którym to kobiety z miast najmniejszych (liczących do 20 tys. mieszkańców) oraz z obszarów wiejskich charakteryzowały się wyższym poziomem kapitału ludzkiego niż mężczyźni. Jednakże zaobserwowane różnice były statystycznie istotne tylko: dla miast największych wyłącznie w roku 2011, dla miast liczących 100-200 tys. mieszkańców tylko w latach 2009 i 2011, dla miast liczących 20-100 tys. mieszkańców we

\footnotetext{
${ }^{33} \mathrm{Na}$ poziomie istotności 0,01 ; jedynym wyjątkiem było porównanie kobiet i mężczyzn przeprowadzone w roku 2007 w grupie wieku $35-44$ lata - było ono istotne na poziomie istotności 0,1 .

${ }^{34}$ Na poziomie istotności 0,01 .
} 
wszystkich analizowanych okresach, dla miast o liczbie mieszkańców poniżej 20 tys. tylko w latach 2009 i 2011. Natomiast w żadnym z analizowanych okresów nie były statystycznie istotne dla mieszkańców wsi oraz miast o liczbie mieszkańców 200-500 tys.

Tabela 4.5.2. Poziom kapitału ludzkiego kobiet i mężczyzn wedtug klasy miejscowości zamieszkania, statusu na rynku pracy oraz statusu społeczno-zawodowego.

\begin{tabular}{|c|c|c|c|c|c|c|c|}
\hline \multirow[b]{2}{*}{$\begin{array}{l}\text { Wartości cech } \\
\text { niezależnych }\end{array}$} & \multirow[b]{2}{*}{ Płeć } & \multicolumn{2}{|c|}{ Kapitał ludzki w 2007} & \multicolumn{2}{|c|}{ Kapitał ludzki w 2009} & \multicolumn{2}{|c|}{ Kapitał ludzki w 2011} \\
\hline & & Średnia & $\begin{array}{c}\text { Błąd } \\
\text { standardowy }\end{array}$ & Średnia & $\begin{array}{c}\text { Błąd } \\
\text { standardowy }\end{array}$ & Średnia & $\begin{array}{c}\text { Błąd } \\
\text { standardowy }\end{array}$ \\
\hline \multicolumn{8}{|c|}{ Klasa miejscowości zamieszkania } \\
\hline \multirow{2}{*}{ Miasta $>500$ tys. } & mężczyzna & 54,88 & 0,68 & 56,07 & 0,40 & 57,77 & 0,37 \\
\hline & kobieta & 54,67 & 0,57 & 55,49 & 0,38 & 56,27 & 0,35 \\
\hline \multirow{2}{*}{ Miasta $200-500$ tys. } & mężczyzna & 52,14 & 0,62 & 53,90 & 0,42 & 55,47 & 0,42 \\
\hline & kobieta & 51,09 & 0,57 & 53,23 & 0,42 & 54,64 & 0,41 \\
\hline \multirow{2}{*}{ Miasta $100-200$ tys. } & mężczyzna & 49,70 & 0,68 & 52,48 & 0,48 & 52,35 & 0,47 \\
\hline & kobieta & 48,94 & 0,63 & 49,84 & 0,49 & 50,09 & 0,46 \\
\hline \multirow{2}{*}{ Miasta 20-100 tys. } & mężczyzna & 48,74 & 0,44 & 49,82 & 0,31 & 50,87 & 0,28 \\
\hline & kobieta & 47,44 & 0,41 & 48,00 & 0,30 & 49,74 & 0,28 \\
\hline \multirow{2}{*}{ Miasta do 20 tys. } & mężczyzna & 45,49 & 0,52 & 47,57 & 0,36 & 49,64 & 0,35 \\
\hline & kobieta & 45,91 & 0,52 & 45,92 & 0,37 & 47,30 & 0,36 \\
\hline \multirow{2}{*}{ Wieś } & mężczyzna & 41,03 & 0,29 & 43,53 & 0,21 & 44,89 & 0,20 \\
\hline & kobieta & 41,30 & 0,30 & 42,97 & 0,22 & 44,41 & 0,22 \\
\hline \multicolumn{8}{|l|}{ Status na rynku pracy } \\
\hline \multirow{2}{*}{ Pracujący } & mężczyzna & 48,64 & 0,26 & 50,81 & 0,17 & 52,38 & 0,16 \\
\hline & kobieta & 52,33 & 0,27 & 53,82 & 0,19 & 54,96 & 0,17 \\
\hline \multirow{2}{*}{ Bezrobotni } & mężczyzna & 43,48 & 0,80 & 46,78 & 0,55 & 50,21 & 0,54 \\
\hline & kobieta & 45,66 & 0,72 & 48,28 & 0,56 & 53,99 & 0,49 \\
\hline \multirow{2}{*}{ Bierni zawodowo } & mężczyzna & 43,44 & 0,35 & 44,19 & 0,25 & 44,63 & 0,24 \\
\hline & kobieta & 41,18 & 0,26 & 41,95 & 0,19 & 42,70 & 0,19 \\
\hline \multicolumn{8}{|c|}{ Status społeczno-zawodowy } \\
\hline \multirow{2}{*}{$\begin{array}{l}\text { Prac. sektora } \\
\text { publicznego }\end{array}$} & mężczyzna & 53,14 & 0,54 & 55,10 & 0,37 & 56,34 & 0,35 \\
\hline & kobieta & 57,65 & 0,41 & 58,58 & 0,29 & 58,97 & 0,28 \\
\hline \multirow{2}{*}{$\begin{array}{l}\text { Prac. sektora } \\
\text { prywatnego }\end{array}$} & mężczyzna & 48,47 & 0,36 & 51,61 & 0,23 & 52,23 & 0,21 \\
\hline & kobieta & 52,42 & 0,40 & 54,65 & 0,28 & 54,37 & 0,26 \\
\hline \multirow{2}{*}{$\begin{array}{l}\text { Prywatni } \\
\text { przedsiębiorcy }\end{array}$} & mężczyzna & 53,52 & 0,64 & 54,78 & 0,44 & 54,80 & 0,42 \\
\hline & kobieta & 54,82 & 1,02 & 58,45 & 0,68 & 58,77 & 0,63 \\
\hline \multirow{2}{*}{ Rolnicy } & mężczyzna & 38,22 & 0,58 & 38,97 & 0,40 & 40,09 & 0,44 \\
\hline & kobieta & 37,44 & 0,56 & 38,76 & 0,49 & 40,69 & 0,54 \\
\hline \multirow{2}{*}{ Renciści } & mężczyzna & 38,37 & 0,59 & 39,71 & 0,45 & 38,86 & 0,41 \\
\hline & kobieta & 35,11 & 0,50 & 34,76 & 0,35 & 34,26 & 0,31 \\
\hline \multirow{2}{*}{ Emeryci } & mężczyzna & 34,26 & 0,32 & 35,56 & 0,23 & 37,14 & 0,26 \\
\hline & kobieta & 33,71 & 0,26 & 34,47 & 0,18 & 35,85 & 0,20 \\
\hline \multirow{2}{*}{ Uczniowie i studenci } & mężczyzna & 62,02 & 0,31 & 64,02 & 0,20 & 63,48 & 0,20 \\
\hline & kobieta & 63,11 & 0,28 & 64,61 & 0,19 & 64,72 & 0,18 \\
\hline \multirow{2}{*}{ Bezrobotni } & mężczyzna & 41,74 & 0,73 & 44,10 & 0,52 & 48,51 & 0,52 \\
\hline & kobieta & 42,55 & 0,54 & 47,16 & 0,48 & 51,00 & 0,44 \\
\hline Inni hierni zawodow & mężczyzna & 42,16 & 0,90 & 43,20 & 0,48 & 46,26 & 0,60 \\
\hline mini Dierni Zawodowo & kobieta & 43,87 & 0,53 & 43,95 & 0,31 & 46,47 & 0,33 \\
\hline
\end{tabular}

Ze względu na status rynku pracy, najwyższym poziomem kapitału ludzkiego charakteryzują się osoby pracujące, następnie bezrobotne, a na końcu - bierne zawodowo. Wniosek ten zasadniczo nie zmienia się w przypadku włączenia do analizy płci. Jedynym wyjątkiem są kobiety bezrobotne, które w roku 2011 charakteryzowały się wyższym poziomem kapitału ludzkiego niż pracujący mężczyźni. Zaobserwowana różnica w wyposażeniu w ten kapitał między tymi dwoma grupami była statystycznie istotna ${ }^{35}$. Warto również zauważyć, że wśród osób pracujących i bezrobotnych to kobiety miały wyższy poziom kapitału ludzkiego (w obu badanych okresach), natomiast wśród biernych zawodowo - mężczyźni. Każdorazowo zaobserwowana różnica w wyposażeniu w ten zasób była statystycznie istotna ${ }^{36}$.

W grupach wyróżnionych według statusu społeczno-zawodowego, we wszystkich analizowanych okresach kobiety charakteryzowały się większym niż mężczyźni kapitałem ludzkim wśród: pracujących w sektorze publicznym i sektorze prywatnym, prywatnych przedsiębiorców, bezrobotnych, innych biernych zawodowo, uczniów i studentów, pracujących w rolnictwie (tylko w roku 2011).

\footnotetext{
${ }^{35} \mathrm{Na}$ poziomie istotności 0,01 .

${ }^{36} \mathrm{Na}$ poziomie istotności 0,01 ;
} 
Tabela 4.5.3. Poziom kapitatu ludzkiego w grupach wieku 15-34 lata, 25-44 lata oraz 45 lat lub więcej wedtug klasy miejscowości zamieszkania, statusu na rynku pracy oraz statusu społeczno-zawodowego.

\begin{tabular}{|c|c|c|c|c|c|c|c|}
\hline \multirow{2}{*}{$\begin{array}{l}\text { Wartości cech } \\
\text { niezależnych }\end{array}$} & \multirow[b]{2}{*}{ Grupa wieku } & \multicolumn{2}{|c|}{ Kapitał ludzki w 2007} & \multicolumn{2}{|c|}{ Kapitał ludzki w 2009} & \multicolumn{2}{|c|}{ Kapitał ludzki w 2011} \\
\hline & & Średnia & $\begin{array}{c}\text { Błąd } \\
\text { standardowy }\end{array}$ & Średnia & $\begin{array}{c}\text { Błąd } \\
\text { standardowy }\end{array}$ & Średnia & $\begin{array}{c}\text { Błąd } \\
\text { standardowy }\end{array}$ \\
\hline \multicolumn{8}{|c|}{ Klasa miejscowości zamieszkania } \\
\hline & $16-34$ & 64,84 & 0,45 & 65,70 & 0,29 & 65,74 & 0,25 \\
\hline \multirow[t]{3}{*}{ Miasta $>500$ tys. } & $35-44$ & 58,93 & 0,97 & 59,93 & 0,60 & 61,93 & 0,51 \\
\hline & 45 i więcej & 45,17 & 0,59 & 46,74 & 0,38 & 48,76 & 0,36 \\
\hline & $16-34$ & 61,47 & 0,51 & 64,28 & 0,30 & 65,53 & 0,29 \\
\hline \multirow[t]{3}{*}{ Miasta $200-500$ tys. } & $35-44$ & 55,48 & 0,95 & 58,84 & 0,61 & 59,95 & 0,54 \\
\hline & $45+$ lat & 42,26 & 0,53 & 43,01 & 0,38 & 45,85 & 0,39 \\
\hline & $16-34$ & 60,15 & 0,61 & 62,22 & 0,38 & 60,71 & 0,41 \\
\hline \multirow[t]{3}{*}{ Miasta $100-200$ tys. } & $35-44$ & 51,29 & 1,08 & 55,59 & 0,82 & 57,07 & 0,71 \\
\hline & 45 i więcej & 41,14 & 0,54 & 42,04 & 0,41 & 43,03 & 0,41 \\
\hline & $16-34$ & 58,98 & 0,37 & 59,84 & 0,28 & 60,97 & 0,23 \\
\hline \multirow[t]{3}{*}{ Miasta $20-100$ tys. } & $35-44$ & 49,65 & 0,70 & 53,46 & 0,46 & 55,75 & 0,41 \\
\hline & $45 \mathrm{i}$ więcej & 39,66 & 0,35 & 40,03 & 0,25 & 41,62 & 0,24 \\
\hline & $16-34$ & 55,12 & 0,55 & 58,12 & 0,34 & 59,81 & 0,30 \\
\hline \multirow[t]{3}{*}{ Miasta do 20 tys. } & $35-44$ & 46,93 & 0,80 & 49,86 & 0,60 & 51,69 & 0,58 \\
\hline & $45 \mathrm{i}$ więcej & 37,77 & 0,42 & 38,62 & 0,29 & 40,10 & 0,29 \\
\hline & $16-34$ & 52,45 & 0,33 & 55,06 & 0,21 & 56,80 & 0,19 \\
\hline \multirow{2}{*}{ Wieś } & $35-44$ & 40,25 & 0,42 & 43,90 & 0,30 & 45,95 & 0,31 \\
\hline & 45 i więcej & 32,91 & 0,20 & 33,84 & 0,14 & 34,84 & 0,15 \\
\hline \multicolumn{8}{|l|}{ Status na rynku pracy } \\
\hline \multirow{4}{*}{ Pracujący } & $16-34$ & 56,59 & 0,28 & 58,66 & 0,18 & 60,34 & 0,16 \\
\hline & $35-44$ & 48,92 & 0,36 & 52,01 & 0,25 & 53,91 & 0,23 \\
\hline & 45 i więcej & 44,93 & 0,29 & 45,65 & 0,19 & 46,93 & 0,18 \\
\hline & $16-34$ & 52,83 & 0,74 & 54,27 & 0,52 & 57,97 & 0,40 \\
\hline \multirow[t]{3}{*}{ Bezrobotni } & $35-44$ & 39,93 & 1,05 & 45,14 & 0,70 & 48,94 & 0,95 \\
\hline & 45 i więcej & 35,68 & 0,58 & 37,35 & 0,53 & 41,97 & 0,62 \\
\hline & $16-34$ & 58,82 & 0,27 & 60,69 & 0,18 & 60,67 & 0,18 \\
\hline \multirow{2}{*}{ Bierni zawodowo } & $35-44$ & 40,11 & 0,73 & 43,19 & 0,59 & 45,38 & 0,57 \\
\hline & 45 i więcej & 33,52 & 0,16 & 34,07 & 0,11 & 35,31 & 0,12 \\
\hline \multicolumn{8}{|c|}{ Status społeczno-zawodowy } \\
\hline \multirow{3}{*}{$\begin{array}{l}\text { prac. sektora } \\
\text { publicznego }\end{array}$} & $16-34$ & 63,62 & 0,48 & 64,34 & 0,33 & 64,35 & 0,31 \\
\hline & $35-44$ & 55,05 & 0,60 & 58,45 & 0,41 & 60,90 & 0,39 \\
\hline & 45 i więcej & 50,52 & 0,51 & 51,66 & 0,34 & 52,71 & 0,33 \\
\hline & $16-34$ & 55,04 & 0,37 & 58,30 & 0,23 & 58,85 & 0,21 \\
\hline prac. sektora & $35-44$ & 46,67 & 0,52 & 51,14 & 0,36 & 52,35 & 0,31 \\
\hline prywatnego & 45 i więcej & 43,98 & 0,47 & 44,69 & 0,31 & 45,27 & 0,28 \\
\hline & $16-34$ & 59,51 & 0,82 & 60,28 & 0,57 & 62,72 & 0,53 \\
\hline prywatni & $35-44$ & 53,37 & 1,10 & 55,99 & 0,68 & 55,75 & 0,61 \\
\hline przedsiębiorcy & 45 i więcej & 50,23 & 0,81 & 52,08 & 0,61 & 51,24 & 0,55 \\
\hline & $16-34$ & 43,59 & 0,94 & 44,16 & 0,73 & 48,93 & 0,81 \\
\hline rolnicy & $35-44$ & 37,80 & 0,68 & 40,86 & 0,55 & 41,99 & 0,64 \\
\hline & 45 i więcej & 34,75 & 0,49 & 35,56 & 0,39 & 36,36 & 0,36 \\
\hline & $16-34$ & 57,47 & 1,12 & 59,74 & 0,82 & 50,68 & 1,63 \\
\hline renciści & $35-44$ & 37,18 & 1,30 & 39,97 & 0,90 & 44,95 & 1,20 \\
\hline & 45 i więcej & 32,86 & 0,28 & 33,20 & 0,21 & 34,77 & 0,24 \\
\hline emeryci & $45 \mathrm{i}$ więcej & 33,90 & 0,20 & 34,84 & 0,14 & 36,30 & 0,16 \\
\hline uczniowie i studenci & $15-34$ & 62,60 & 0,21 & 64,33 & 0,14 & 64,14 & 0,13 \\
\hline & $16-34$ & 48,79 & 0,71 & 53,58 & 0,49 & 56,33 & 0,38 \\
\hline bezrobotni & $35-44$ & 39,51 & 0,85 & 44,76 & 0,73 & 46,94 & 0,80 \\
\hline & $45 \mathrm{i}$ więcej & 36,12 & 0,48 & 36,45 & 0,38 & 39,56 & 0,51 \\
\hline & $15-34$ & 49,93 & 0,66 & 50,07 & 0,39 & 54,50 & 0,41 \\
\hline inni bierni zawodowo & $35-44$ & 41,37 & 0,88 & 43,39 & 0,52 & 46,55 & 0,58 \\
\hline & $45 \mathrm{i}$ więcej & 35,95 & 0,59 & 36,29 & 0,33 & 37,99 & 0,36 \\
\hline
\end{tabular}

Wszystkie zaobserwowane różnice w wyposażeniu w kapitał ludzki między kobietami i mężczyznami w wymienionych grupach według statusu społeczno-zawodowego były statystycznie istotne ${ }^{37}$. Od powyższej prawidłowości zaobserwowano dwa wyjątki dotyczące grup bezrobotnych i prywatnych przedsiębiorców. W roku 2007 różnice między kobietami i mężczyznami na korzyść kobiet były statystycznie nieistotne.

\footnotetext{
${ }^{37}$ Na poziomie istotności 0,01 ;
} 
Natomiast mężczyźni charakteryzowali się wyższym od kobiet poziomem kapitału ludzkiego wśród: rolników (w latach 2007 i 2009), emerytów, rencistów, przy czym różnice w wyposażeniu w kapitał ludzki były statystycznie istotne tylko w grupach emerytów i rencistów.

Biorąc pod uwagę status społeczno-zawodowy, w każdym z analizowanych okresów najwyższym poziomem kapitału ludzkiego charakteryzowały się uczennice i studentki, następnie uczniowie i studenci i kobiety pracujące w sektorze publicznym, pracujące jako prywatni przedsiębiorcy oraz pracujące w sektorze prywatnym. Natomiast najsłabiej wyposażeni w ten zasób są emerytki i rencistki oraz emeryci i renciści.

Analogiczne analizy przeprowadzono dla wieku, czyli sprawdzono, jak kształtował się poziom kapitału ludzkiego ze względu na grupę wieku oraz: wielkość miejscowości zamieszkania, status na rynku pracy, status społeczno-zawodowy. Wyniki zestawiono w tabeli 4.5.3.

Ponownie najwyższym poziomem kapitału ludzkiego charakteryzowały się osoby najmłodsze (25-34 lata), natomiast najniższym - osoby w wieku co najmniej 45 lat. Prawidłowość ta została potwierdzona we wszystkich przekrojach ze względu na wielkość miejscowości zamieszkania, status na rynku pracy oraz status społeczno-zawodowy.

Aby zbadać łączny wpływ rozpatrywanych cech tzn. płci, wieku, klasy miejscowości zamieszkania oraz statusu na rynku pracy w Polsce w 2011 roku, oszacowano model regresji dwupoziomowej z losowym wyrazem wolnym. Poziom pierwszy analizy stanowili członkowie gospodarstw domowych, zaś poziom drugi ich - gospodarstwa domowe. Zastosowanie modelu dwupoziomowego było konieczne ze względu na przypuszczenie, że kapitał ludzki członków jednego gospodarstwa domowego jest wyraźnie ze sobą skorelowany. Aby potwierdzić to przypuszczenie, dla wskaźnika kapitału ludzkiego w roku 2011 obliczono współczynnik korelacji wewnątrzgrupowej (ang. intraclass correlation coefficient). Uzyskana wartość na poziomie 0,595 jest wielkością znaczącą i oznacza, że wpływ przynależności do gospodarstwa domowego na poziom kapitału ludzkiego jest na tyle duży, że nie należy go ignorować. Ponadto w takiej sytuacji stosowanie klasycznego (jednopoziomowego) modelu regresji prowadzić może do nieprawidłowych wyników. Oceny parametrów efektów stałych dla ostatecznego modelu ${ }^{38}$ zestawiono w tabeli 4.5.4.

Tabela 4.5.4. Oceny parametrów efektów stałych w modelu regresji dwupoziomowej z losowym wyrazem wolnym ${ }^{39}$, Diagnoza Społeczna 2011

\begin{tabular}{lccc}
\hline Zmienne & Oszacowanie & Błąd standardowy & Istotność \\
\hline Stała & 33,39 & 0,20 & 0,00 \\
\hline Status na rynku pracy & & & 0,00 \\
pracujący & 6,05 & 0,17 & 0,00 \\
bezrobotni & 4,63 & 0,36 & 0,00 \\
bierni zawodowo & ref. & & 0,00 \\
\hline Wiek & 18,48 & 0,13 & 0,00 \\
15-34 & 8,72 & 0,20 & 0,00 \\
35-44 & ref. & \\
45 i więcej & & & 0,00 \\
\hline Status na rynku pracy i płeć & $-1,58$ & 0,14 & \\
pracujący mężczyzna & ref. & 0,00 \\
pracująca kobieta & $-2,56$ & 0,48 & \\
bezrobotny mężczyzna & ref. & 0,00 \\
bezrobotna kobieta & 0,83 & 0,18 & 0,00 \\
bierny zawodowo mezżczyzna & ref. & & 0,00 \\
bierna zawodowo kobieta & & & 0,00 \\
\hline Klasa miejscowości & 11,58 & 0,35 & \\
miasta o liczbie mieszkańców 500 tys. i więcej & 10,07 & 0,37 & \\
miasta o liczbie mieszkańców 200-500 tys. & 6,76 & 0,40 & 0,29 \\
miasta o liczbie mieszkańców 100-200 tys. & 5,98 & 0,33 & \\
miasta o liczbie mieszkańców 20-100 tys. & 4,27 & & \\
miasta o liczbie mieszkańców poniżej 20 tys. & ref. & & \\
wieś & & & \\
\hline
\end{tabular}

Uzyskane rezultaty są zgodne z wynikami wcześniejszych analiz opisowych. Potwierdzają zatem, że pod względem kapitału ludzkiego istotnie różnią się między sobą osoby o różnym statusie na rynku pracy (najwyższy kapitał ludzki mają osoby pracujące, mniejszy osoby bezrobotne, a najniższy bierni zawodowo); aktywne zawodowo kobiety (zarówno pracujące jak i bezrobotne) mają wyższy kapitał ludzki niż aktywni zawodowo mężczyźni, jednak wśród osób biernych zawodowo to mężczyźni charakteryzują się wyższym poziomem kapitału ludzkiego; różnicuje wiek - prawidłowością jest, że im młodsza osoba, tym kapitał ludzki jest wyższy -- oraz klasa

\footnotetext{
${ }^{38}$ Modele regresji wielopoziomowej estymuje się iteracyjnie. Oznacza to, że rozpoczyna się od modelu jedynie ze stałą i w kolejnych krokach włącza się do modelu kolejne zmienne, podejmując jednocześnie decyzje o uwzględnieniu efektów stałych i/lub losowych. Jakość oszacowanych modeli ocenia się na podstawie kryteriów informacyjnych i za pomocą testu ilorazu wiarygodności.

${ }^{39}$ Parametry szacowano metodą residual maximum likelihood (REML)
} 
miejscowości zamieszkania - im większa miejscowość zamieszkania, tym kapitał ludzki członków gospodarstw jest wyższy.

\subsubsection{Podsumowanie}

Rezultaty analiz wykorzystujących dane Diagnozy Społecznej 2011 potwierdziły kontynuację tendencji wzrostowej kapitału ludzkiego polskiego społeczeństwa. Wynika ona przede wszystkim z utrzymywania się rosnącego trendu korzystania z nowoczesnych technologii informatycznych, bowiem inne składowe pomiaru kapitału (znajomość języka angielskiego, kształcenie ustawiczne) wskazują na stagnację bądź nawet regres odpowiednich wartości. W 2011 roku utrzymują się zasadnicze, korzystne dla osób młodszych, różnice w wyposażeniu w kapitał ludzki między nimi a osobami starszymi. $Z$ jednej strony jest to dobry sygnał, który pokazuje, że kolejne roczniki wchodzące na rynek pracy będą $w$ stanie sprostać wymaganiom narzuconym przez nowoczesne technologie. $Z$ drugiej strony, dysproporcje w poziomie kapitału ludzkiego między wyróżnionymi grupami wieku oraz między grupami wieku z kontrolą płci zmniejszyły w roku 2011 w porównaniu z latami 2009 i 2007 wyłącznie w przypadku najmłodszej grupy wieku. Dla najstarszej grupy wieku różnice wzrosły. Wskazuje to na szczególne zagrożenie narastania dysproporcji kapitału ludzkiego według wieku i potwierdza kluczową rolę kształcenia ustawicznego w celu w przeciwdziałania tej zmianie. Ten wynik unaocznia również, iż zatrzymanie na rynku pracy osób w starszych grupach wieku produkcyjnego - uznawane za konieczne w celu przeciwdziałania wielorakim skutkom zmiany struktur wieku ludności - wymaga znaczącego wysiłku w celu poprawy ich kapitału ludzkiego.

Wśród osób w wieku mobilnym kobiety dysponują większym kapitałem ludzkim niż mężczyźni. Dla osób w wieku 45 lat i więcej ta relacja ulega odwróceniu. Ponieważ niska aktywność zawodowa osób w starszych grupach wieku produkcyjnego jest silnie zdeterminowana wcześniejszym wycofywaniem się kobiet z rynku pracy, wynik ten unaocznia jak ważna jest poprawa kapitału ludzkiego kobiet w tym wieku dla wzrostu zatrudnienia w tej grupie ludności.

Niekorzystne dla mieszkańców wsi różnice w wyposażeniu w kapitał ludzki nieznacznie się zmniejszyły, choć nadal charakteryzują się oni najniższym poziomem kapitału ludzkiego. Mimo poprawy poziomu kapitału ludzkiego utrzymuje się niska pozycja osób pracujących w rolnictwie w uporządkowaniu grup społeczno-zawodowych według poziomu tego kapitału. To podkreśla skalę niezbędnych inwestycji w kapitał ludzki zarówno mieszkańców wsi jak i rolników. Inwestycje te konieczne są do zmniejszenia nierówności w poziomie kapitału, które mogą hamować przekształcenia obszarów wiejskich. Wyższy poziom kapitału ludzkiego na wsi będzie oznaczał zdolność adoptowania nowoczesnych technologii przez gospodarstwa rolne, co w kraju wysokorozwiniętym jest konieczne do zapewnienia konkurencyjności w tym sektorze gospodarki.

Analiza kapitału ludzkiego ze względu na status na rynku pracy pokazuje, jak istotną rolę w jego kształtowaniu odgrywa fakt uczestnictwa w rynku pracy. Na podkreślenie zasługuje poprawa poziomu kapitału nie tylko wśród osób pracujących, ale także bardzo widoczna zmiana wśród osób bezrobotnych. Różnica między osobami pracującymi a bezrobotnymi w okresie 2009 - 2011 zmniejszyła się ponad trzykrotnie, zaś w latach 2007 - 2011 czterokrotnie. Można przypuszczać, że przyczyniły się do tego także programy rozwoju zasobów ludzkich, tak szeroko wykorzystywane w ostatnich latach. Jednak innym czynnikiem tej zmiany może być rosnące zagrożenie bezrobociem osób z wykształceniem wyższym, zwłaszcza wśród osób młodych wkraczających na rynek pracy. Za tym przypuszczeniem zdaje się przemawiać także innym wynik - kobiety bezrobotne mają wyższy poziom kapitału ludzkiego nie tylko od mężczyzn poszukujących pracy, ale także od mężczyzn pracujących. Niepokojące jest także to, że nadal narasta dysproporcja w poziomie kapitału ludzkiego między osobami aktywnymi i biernymi zawodowo. Konieczność wzrostu zatrudnienia w Polsce wymaga również aktywizacji osób pozostających poza rynkiem pracy, a to może być trudne ze względu na rosnące różnice w wyposażeniu w kapitał ludzki.

Wyniki analiz pokazały również, że największym zasobem kapitału ludzkiego charakteryzują się studenci. W trakcie studiów zdobywają oni konieczne umiejętności posługiwania się bazą wiedzy dostępną dzięki nowoczesnym technologiom. Należy jednak pamiętać, że w kolejnych latach będą oni musieli wykorzystywać zdobyte umiejętności w pracy. Niestety coraz częściej pojawiają się głosy, że uczelnie nie przygotowują właściwie do wykorzystywania zdobytej wiedzy w praktyce. Dodatkowo wskazuje się na niedostosowanie struktury kształcenia według kierunków do potrzeb gospodarki (nadmiar absolwentów kierunków społecznych i humanistycznych oraz niedobór absolwentów kierunków ścisłych i technicznych). Te spostrzeżenia zdają się potwierdzać przytoczone wyżej uwagi. Znacząca poprawa kapitału ludzkiego bezrobotnych w 2011 r. w porównaniu z latami 2009 i 2007 może wynikać także z większego ryzyka bezrobocia wśród osób o stosunkowo wysokim poziomie wykształcenia. 


\subsubsection{Kształcenie dzieci}

Tomasz Panek

Zdecydowana większość gospodarstw domowych chciała w marcu 2011 r., aby ich dzieci ukończyły szkołę wyższą na poziomie magisterskim (prawie 69 proc.). Natomiast ponad 20 proc. gospodarstw uważało za wystarczający poziom wykształcenia dla ich dzieci ukończenie technikum lub liceum zawodowego, a prawie 15 proc. — szkoły wyższej zawodowej (licencjat). Przeciętne szanse uzyskania powyższych poziomów wykształcenia gospodarstwa domowe oceniają jako dosyć duże.

Najczęściej ukończenie przez ich dzieci szkoły wyższej na poziomie magisterskim wskazywały w marcu $2011 \mathrm{r}$. gospodarstwa domowe pracujących na własny rachunek i gospodarstwa pracowników (odpowiednio ponad 76 i ponad 72 proc. gospodarstw) oraz gospodarstwa małżeństw z 2 dzieci (ponad 75 proc. gospodarstw). Gospodarstwa domowe bez bezrobotnych zdecydowanie częściej wskazywały na ten poziom wykształcenia niż gospodarstwa domowe $\mathrm{z}$ bezrobotnymi (prawie 72 proc. gospodarstw w pierwszą $\mathrm{z}$ tych grup wobec 56 proc. gospodarstw w drugiej z grup). Gospodarstwa o tego typu aspiracjach w zakresie kształcenia dzieci najczęściej zamieszkiwały duże miasta powyżej 200 tys. mieszkańców, (ponad 78 proc. gospodarstw z tych miast) oraz województwa świętokrzyskie i lubelskie (odpowiednio ponad 85 i prawie 82 proc. gospodarstw z tych województw). Najrzadziej ten poziom wykształcenia dzieci jako spełnienie swoich aspiracji wskazywały gospodarstwa utrzymujących się z niezarobkowych źródeł (około 37 proc. gospodarstw) oraz gospodarstwa wielorodzinne (niecałe 59 proc. gospodarstw). Gospodarstwa te relatywnie najczęściej zamieszkiwały wieś (około 64 proc. gospodarstw) oraz województwo warmińsko-mazurskie (niecałe 52 proc. gospodarstw).

Gospodarstwami domowymi, które jako pożądany poziom wykształcenia swoich dzieci uznały ukończenie technikum lub liceum zawodowego, relatywnie najczęściej były gospodarstwa utrzymujących się z niezarobkowych źródeł i rencistów (odpowiednio ponad 36 i ponad 35 proc. gospodarstw z tych grup) oraz gospodarstwa małżeństw wielodzietnych (ponad 31 proc. gospodarstw). Gospodarstwa o tym poziomie aspiracji w zakresie wykształcenia dzieci relatywnie najczęściej zamieszkiwały wieś (prawie 28 proc. gospodarstw) oraz województwa pomorskie i wielkopolskie (po ponad 25 proc. gospodarstw).

Najczęściej gospodarstwa domowe były zmuszane ze względów finansowych w r. szkolnym 2010/2011 do rezygnacji z zajęć dodatkowych i korepetycji dla dziecka (odpowiednio ponad 14 i ponad 12 proc. gospodarstw). Najrzadziej dochodziło do zmiany szkoły na wymagającą mniejszych opłat (w niecałe 1 proc. gospodarstw).

W latach 2007-2011 $1^{40}$ obserwujemy spadek wszystkich rodzajów wymuszonych sytuacją finansową rezygnacji i ograniczeń w zakresie kształcenia dzieci, przy czym największy w przypadku zawieszenia opłat za szkołę (o prawie 6 p.p, wykres 4.5.8).

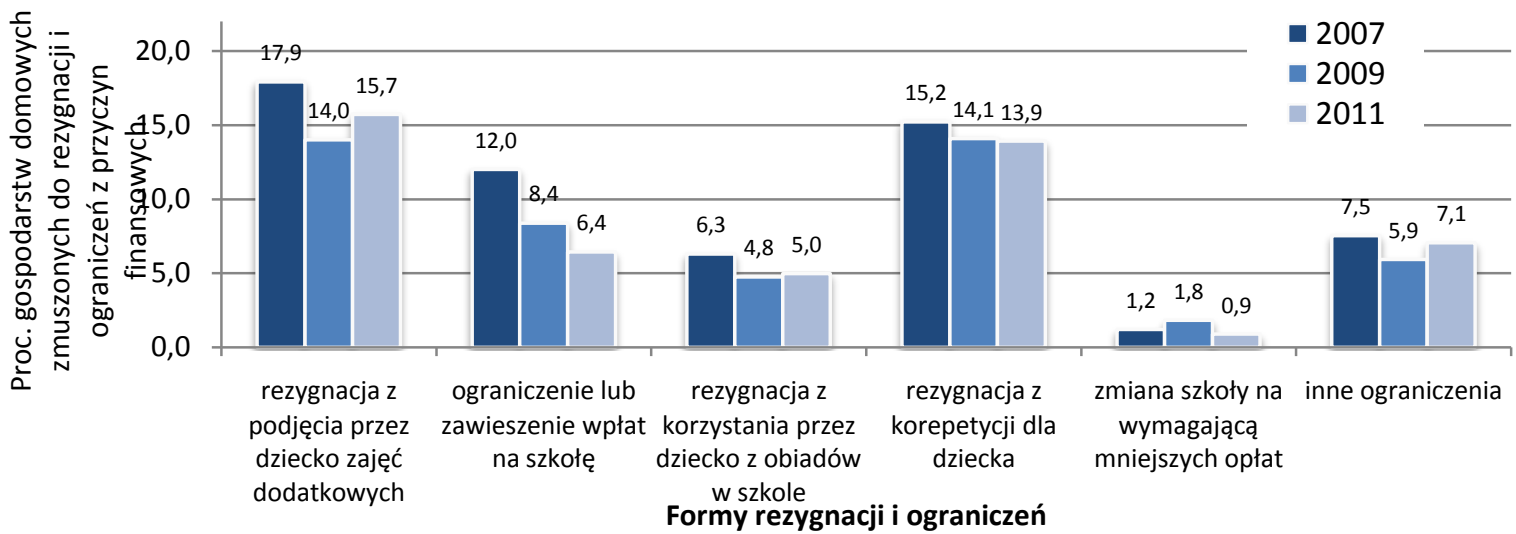

Wykres 4.5.8. Trudności finansowe gospodarstw domowych $w$ zakresie kształcenia dzieci w latach 2007-2011 w próbie panelowej.

W ostatnich dwóch latach ${ }^{41}$ nie nastąpiły istotne zmiany w częstotliwości rezygnacji i ograniczeń gospodarstw domowych w obszarze kształcenia dzieci (wykres 4.5.9).

Gospodarstwami domowymi, które były najczęściej zmuszane do różnego rodzaju ograniczeń finansowych związanych z kształceniem dzieci, były gospodarstwa utrzymujących się z niezarobkowych źródeł i rencistów (odpowiednio ponad 40 i ponad 25 proc. gospodarstw w przypadku rezygnacji z zajęć dodatkowych). Znacznie częściej do ograniczeń w zakresie kształcenia dzieci były zmuszane ze względów finansowych gospodarstwa domowe z bezrobotnymi niż gospodarstwa domowe bez bezrobotnych. Analiza skali wymuszonych ze względów

\footnotetext{
40 Wszystkie zmiany w zakresie kształcenia dzieci w latach 2007-2011 dotyczą próby gospodarstw domowych dla tych lat, czyli tych gospodarstw domowych, które zostały zbadane zarówno w 2007 r. jak i w latach 2009 oraz 2011.

${ }^{41}$ Zmiany w zakresie kształcenia dzieci w latach 2009-2011 dla tych lat, czyli tych gospodarstw domowych, które zostały zbadane zarówno z 2009 jak i w 2011 r.
} 
finansowych ograniczeń w zakresie kształcenia dzieci według typu gospodarstwa wskazuje, że najliczniej dotknęły one w badanym okresie gospodarstwa rodzin niepełnych oraz małżeństw wielodzietnych (odpowiednio prawie $23 \mathrm{i}$ ponad 20 proc. gospodarstw z tych grup w przypadku rezygnacji z zajęć dodatkowych). Relatywnie najczęściej do omawianych ograniczeń zmuszane były gospodarstwa zamieszkujące największe miasta, miasta średniej wielkości o liczbie mieszkańców 100-200 tys. oraz województwo warmińsko-mazurskie (odpowiednio prawie 18, ponad 17 i ponad 21 proc. gospodarstw w przypadku rezygnacji z zajęć dodatkowych).

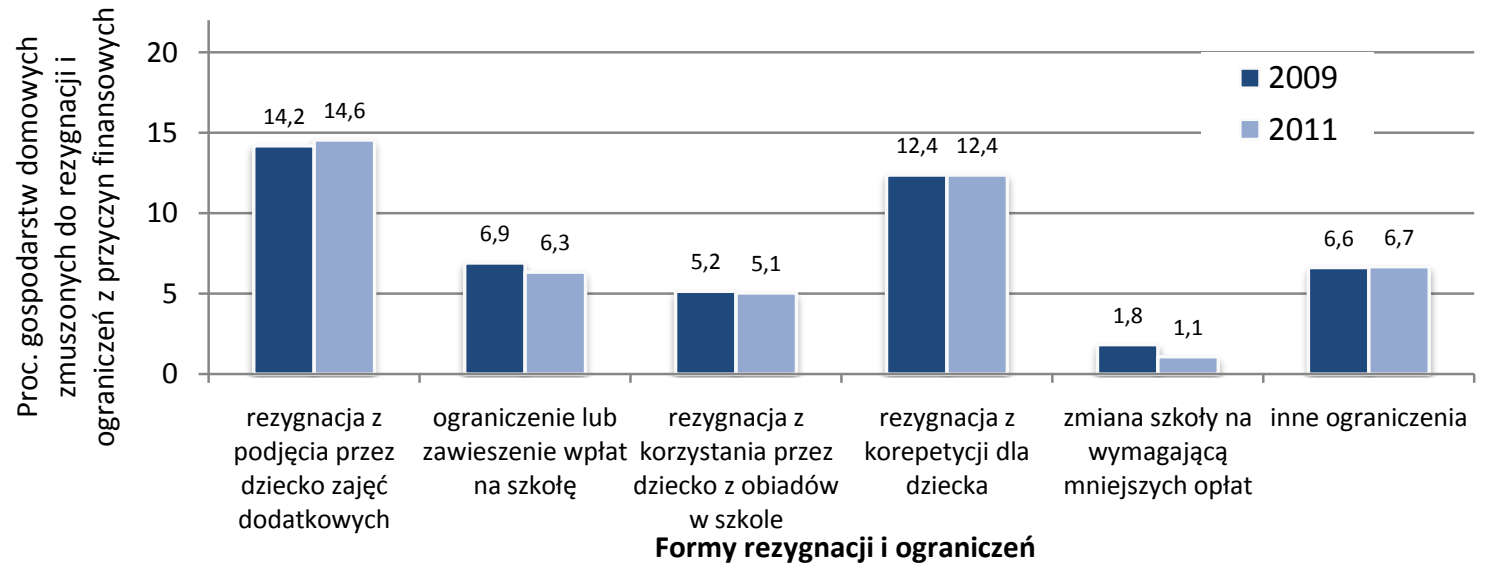

Wykres 4.5.9. Trudności finansowe gospodarstw domowych w zakresie kształcenia dzieci w 2009 i 2011 r. w próbie panelowej.

W ciągu ostatnich dwóch lat nastąił znaczący wzrost ograniczeń, szczególnie w przypadku rezygnacji z podjęcia przez dziecko zajęć dodatkowych, w grupie gospodarstw domowych utrzymujących się z niezarobkowych źródeł, wielorodzinnych oraz zamieszkujących najmniejsze miasta (odsetek gospodarstw zmuszonych do rezygnacji wzrósł odpowiednio o ponad 11, ponad 5 oraz ponad 2 p.p).

Prawie 78 proc. gospodarstw domowych uważało w marcu 2011 r., że poziom zaspokojenia ich potrzeb związanych z kształceniem dzieci w porównaniu do sytuacji sprzed dwóch lat nie zmienił się, około 16 proc. odczuło pogorszenie, a niecałe 6 proc. poprawę. W stosunku do 2009 r. wzrósł odsetek ocen negatywnych, przy jednoczesnym spadku odsetka ocen pozytywnych, odnośnie zmian w poziomie zaspokojenia rozważanych potrzeb gospodarstw domowych w ostatnich dwóch latach. Najczęściej zmiany na gorsze deklarowały gospodarstwa domowe utrzymujących się z niezarobkowych źródeł i rencistów (odpowiednio prawie 36 i ponad 26 proc. gospodarstw) oraz gospodarstwa domowe rodzin niepełnych i rodzinne wielodzietne (odpowiednio prawie 23 i ponad 21 proc. gospodarstw). Widoczna jest znacząca przewaga częstości występowania gospodarstw domowych z bezrobotnymi nad gospodarstwami bez bezrobotnych, uważającymi, że ich zaspokojenie potrzeb związanych z kształceniem dzieci pogorszyło się, w stosunku do sytuacji sprzed dwóch lat (odpowiednio ponad 26 proc. i ponad 14 proc. gospodarstw w tych grupach). Gospodarstwa domowe wskazujące na pogorszenie się stopnia zaspokojenia ich potrzeb w zakresie kształcenia dzieci nie są zróżnicowane znacząco ze względu na klasę miejscowości zamieszkania. Najczęściej negatywne oceny zmian w omawianym obszarze deklarowały gospodarstwa domowe zamieszkujące województwa łódzkie, dolnośląskie i lubuskie (odpowiednio ponad 21 i po ponad 20 proc. gospodarstw). 


\subsection{Kultura i wypoczynek}

\subsubsection{Kultura}

Tomasz Panek, Janusz Czapiński

Od 20 do 13 proc. badanych gospodarstw domowych musiało z powodów finansowych zrezygnować w $2011 \mathrm{r}$. z wyjścia do kina, teatru, opery, operetki, filharmonii (na koncert), zwiedzenia muzeum czy też wystawy, z zakupu książki lub prasy Najwięcej rezygnacji (20,4 proc. gospodarstw) dotyczyło zakupu książki a najmniej (12,6 proc.) zwiedzenia muzeum lub wystawy. Nastapiła jednak pod tym względem wyraźna poprawa w ciągu ostatnich czterech lat $^{42}$ (wykres 4.6.1). Liczba gospodarstw domowych, które musiały zrezygnować $\mathrm{z}$ wyjścia na imprezy kulturalne lub zakupu książek i prasy zmniejszyła się w stosunku do 2007 r. w próbie panelowej od prawie 6 p.p. w przypadku teatru do ponad 3 p.p. w przypadku muzeum. Warto jednak podkreślić, że spadek rezygnacji ze względów finansowych wynikał głównie ze spadku zainteresowania tymi formami uczestnictwa w kulturze Brak potrzeby uczestniczenia w kulturze wzrósł w stosunku do 2007 r. od 8 p.p. w przypadku muzeum i wystawy do 2,5 p.p. w przypadku zakupu prasy.

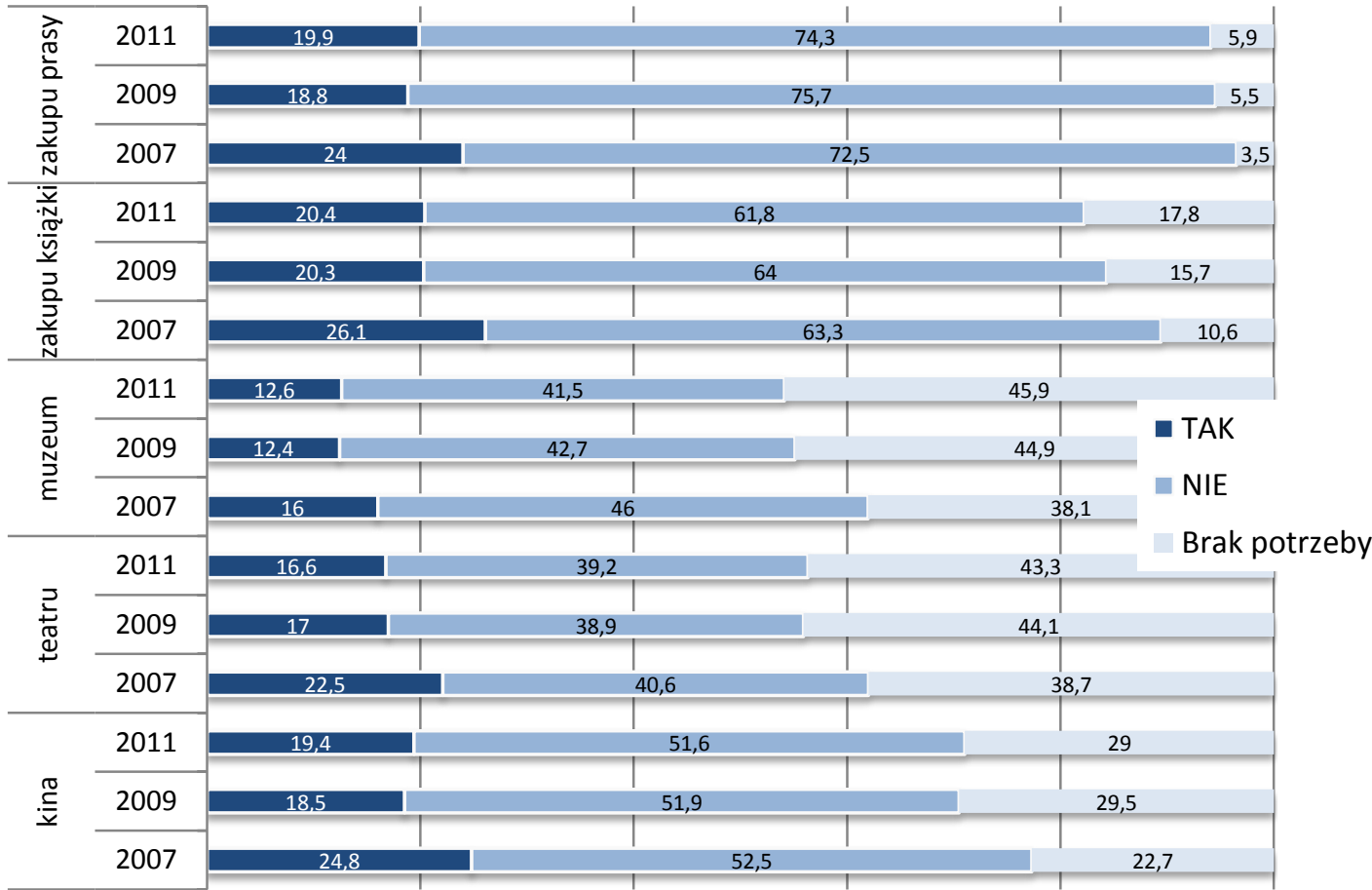

Wykres 4.6.1 Czy ktokolwiek z członków gospodarstwa domowego musiał z powodu braku pieniędzy zrezygnować w ostatnim roku z: (dane z próby panelowej 2007-2011 w procentach odpowiedzi)

W 2011 r. w porównaniu z 2009 r. ${ }^{43}$ skala trudności finansowych gospodarstw domowych w korzystaniu z wybranych form uczestnictwa w kulturze nie zmieniła się istotnie (wykres 4.6.1.2).

Zdecydowanie najwyższy odsetek gospodarstw (nawet ponad 57 proc. w przypadku teatru, opery, operetki, filharmonii lub koncertu) zmuszonych do rezygnacji z korzystania $\mathrm{z}$ wybranych form uczestnictwa w kulturze charakteryzował w marcu 2011 r. grupę gospodarstw najuboższych, utrzymujących się z niezarobkowych źródeł, a najmniejszy (16 proc. lub mniej) gospodarstw pracujących na własny rachunek. Jednocześnie właśnie w tej pierwszej grupie gospodarstw zwiększyła się znacząco w 2011 r. w porównaniu z 2009 rokiem liczba tych rezygnacji (od prawie 4 p.p. w przypadku kina do ponad 9 p.p. w przypadku teatru, opery, operetki, filharmonii, koncertu oraz muzeum lub wystawy). Druga grupa gospodarstw, w której zanotowano wzrost tego typu rezygnacji w ostatnich dwóch latach, były gospodarstwa domowe pracowników (o ponad 2 p.p. w przypadku teatru, opery, operetki, filharmonii i koncertu oraz o ponad 1 punkt procentowy w przypadku muzeum lub wystawy).

Wśród grup gospodarstw domowych wyróżnionych ze względu na typ najczęściej musiały rezygnować $z$ wybranych form uczestnictwa w kulturze gospodarstwa rodzin niepełnych oraz wielodzietnych, w których częstość

\footnotetext{
${ }^{42}$ Wszystkie zmiany w zakresie uczestnictwa gospodarstw domowych w kulturze w latach 2007-2011 dotyczą próby panelowej z tych lat, czyli tych gospodarstw domowych, które zostały zbadane w 2007 r. jak i w 2009 r. oraz w 2011 r.

${ }^{43}$ Wszystkie zmiany w zakresie uczestnictwa gospodarstw domowych w latach 2009-2011 dotyczą próby panelowej dla tych lat, czyli tych gospodarstw domowych, które zostały zbadane zarówno w 2009 r. jak i w 2011 r.
} 
rezygnacji z tych form uczestnictwa w kulturze przekraczała nawet 40 proc. W $2011 \mathrm{r}$. nie nastapiły, w stosunku do sytuacji sprzed dwóch lat, znaczące zmiany w częstości rezygnacji $\mathrm{z}$ tych form uczestnictwa w kulturze w analizowanych typach gospodarstw domowych.

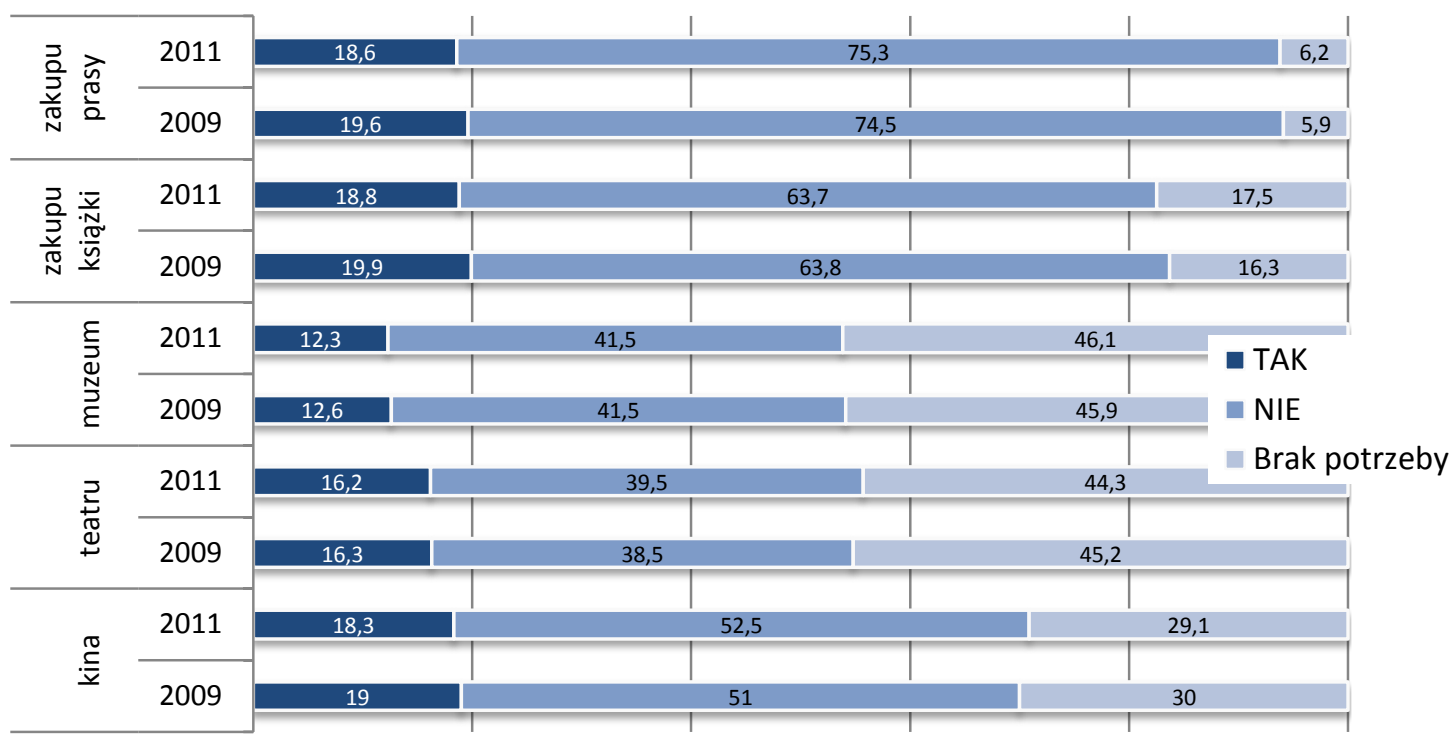

Wykres 4.6.2 Czy ktokolwiek z członków gospodarstwa domowego musiał z powodu braku pieniędzy zrezygnować w ostatnim roku z: (dane z próby panelowej 2009-2011 w procentach odpowiedzi)

Rezygnacje ze względów finansowych ze wszystkich analizowanych form uczestnictwa w kulturze, w gospodarstwach domowych z bezrobotnymi były w 2011 r. o około 20 p.p. częstsze niż w gospodarstwach domowych bez bezrobotnych. W ostatnich dwóch latach nie obserwujemy znaczących zmian odsetka gospodarstw zmuszanych ze względów finansowych do tego typu rezygnacji w obu grupach gospodarstw.

Zróżnicowanie pomiędzy grupami gospodarstw domowych zamieszkujących różne klasy miejscowości, pod względem konieczności rezygnacji ze względów finansowych z wybranych form uczestnictwa w kulturze, nie było w 2011 r. zbyt duże. Rozpatrując rezygnacje w układzie wojewódzkim, najczęściej zgłaszały ten fakt gospodarstwa domowe zamieszkujące województwo łódzkie. W ostatnich dwóch latach wzrost konieczności rezygnacji, ze względów finansowych, $\mathrm{z}$ wybranych form uczestnictwa w kulturze obserwujemy w największych miastach (o ponad 3 p.p. w przypadku rezygnacji z teatru, opery, operetki, filharmonii, koncertu oraz muzeum i wystawy) oraz w miastach o liczbie mieszkańców 100-200 tys. (o ponad 3 p.p. w przypadku rezygnacji z muzeum lub wystawy). Zmniejszenie się możliwości uczestnictwa w kulturze w tym okresie zgłaszały gospodarstwa zamieszkujące województwa opolskie (wzrost zgłoszeń o prawie 3 do ponad 5 p.p), podlaskie (wzrost od ponad 1 do prawie 7 p.p), dolnośląskie (wzrost od prawie 5 do ponad 11 p.p) oraz małopolskie (wzrost zgłoszeń od ponad 2 do ponad 6 p.p).

Prawie 23 proc. badanych gospodarstw zostało zmuszonych w ostatnim roku do rezygnacji ze względów finansowych z zakupu książki. Liczba rezygnacji w 2011 r. spadła w stosunku do 2007 r. o prawie 5 p.p. (wykres 4.6.1.1). W ostatnich dwóch latach odsetek rezygnacji ze względów finansowych z zakupu książki zmniejszył się o 1 punkt procentowy (wykres 4.6.1.2).

Wyraźnie najczęściej rezygnacje z zakupu książki dotyczyły w 2011 r. gospodarstw domowych utrzymujących się z niezarobkowych źródeł (ponad 53 proc. gospodarstw), rodzin niepełnych i nierodzinnych jednoosobowych (odpowiednio prawie 33 proc. i prawie 29 proc. gospodarstw) oraz gospodarstw domowych z bezrobotnymi (prawie 38 proc. gospodarstw). Tylko w grupie gospodarstw domowych utrzymujących się z niezarobkowych źródeł nastapił wzrost rezygnacji, ze względów finansowych, z zakupu książek w 2011 r. w stosunku do 2009 r. (o prawie 13 p.p).

Konieczność rezygnacji z zakupu książki gospodarstwa domowe wiejskie zgłaszały podobnie często jak gospodarstwa domowe miejskie. Zróżnicowanie międzywojewódzkie gospodarstw, które musiały rezygnować ze względów finansowych z zakupu książki, było także stosunkowo nieznaczne. Najczęściej konieczność takiej rezygnacji zgłaszały gospodarstwa domowe zamieszkujące województwo łódzkie (ponad 32 proc. gospodarstw). W 2011 r. w porównaniu z 2009 r. nastąpił znaczący wzrost konieczności rezygnacji gospodarstw domowych z zakupu tylko w największych miastach (o prawie 4 p.p). Istotny wzrost tego typu sytuacji obserwujemy w układzie wojewódzkim wyłącznie w województwach dolnośląskim (o prawie 3 p.p) oraz opolskim (o prawie 2 p.p).

Ponad 19 proc. gospodarstw było zmuszonych, w 2011 r., do rezygnacji ze względów finansowych z zakupu prasy. W 2011 r. w stosunku do roku 2007 liczba rezygnacji spadła o ponad 4 p.p. (wykres 4.6.1.1). Natomiast w ciagu ostatnich dwóch lat nie obserwujemy znaczących zmian w trudnościach finansowych w zakupie prasy (wykres 4.6.1.2). 
Grupą społeczno-ekonomiczną, którą zdecydowanie najsilniej dotknęły ograniczenia w zakupie prasy w $2011 \mathrm{r}$. były gospodarstwa utrzymujących się z niezarobkowych źródeł (ponad 45 proc. gospodarstw zrezygnowało z zakupu prasy). Najrzadziej ograniczenia finansowe w zakupie prasy zgłaszały natomiast gospodarstwa pracujaccych na własny rachunek (około 11 proc. gospodarstw). Częstość rezygnacji z zakupu prasy wzrosła znacząco w $2011 \mathrm{r}$. w porównaniu z 2009 r., w grupie gospodarstw domowych utrzymujących się z niezarobkowych źródeł (wzrost o prawie 6 p.p).

Konieczność rezygnacji z zakupu prasy występowała w 2011 r. zdecydowanie częściej w grupie gospodarstw domowych $\mathrm{z}$ bezrobotnymi niż $\mathrm{w}$ grupie gospodarstw domowych bez bezrobotnych (odpowiednio w ponad 32 proc. gospodarstw i w ponad 17 proc. gospodarstw z tych grup). W latach 2011 - 2009 w obu grupach gospodarstw domowych nie nastapiły znaczące zmiany częstości tego typu rezygnacji.

Wśród typów gospodarstw najczęściej brak pieniędzy na zakup prasy dotyczył w 2011 r. rodzin wielodzietnych oraz niepełnych (odpowiednio ponad 28 i ponad 25 proc. gospodarstw). W ostatnich dwóch latach nie nastąpiły znaczące zmiany w skali rezygnacji z zakupu prasy w żadnym z typów gospodarstw domowych.

$\mathrm{Z}$ zakupu prasy najczęściej musiały rezygnować ze względów finansowych w 2011 r. gospodarstwa zamieszkujące małe miasta o liczbie mieszkańców 20-100 tys. (ponad 20 proc. gospodarstw). Brak pieniędzy na zakup prasy zdecydowanie najczęściej dotykał gospodarstwa zamieszkujące województwa łódzkie, zachodniopomorskie i dolnośląskie (odpowiednio ponad 25, prawie 24 i ponad 23 proc. gospodarstw). Wzrost tego typu rezygnacji, w ostatnich dwóch latach, obserwujemy w największych miastach i w małych miastach o liczbie mieszkańców 20-100 tys. (o prawie 2 p.p) oraz w województwach dolnośląskim oraz podkarpackim (o odpowiednio ponad 5 oraz o prawie 4 p.p).

W 2011 r. oprócz rezygnacji gospodarstw domowych z uczestnictwa w kulturze z powodów finansowych, badano także brak odczuwania przez nie takiej potrzeby. Najrzadziej gospodarstwa deklarują brak potrzeby zakupu prasy (6 proc. gospodarstw), a najczęściej zwiedzania muzeum lub wystawy (44 proc. gospodarstw). Brak potrzeby wyjścia do teatru, opery, operetki, filharmonii czy na koncert zgłasza prawie 42 proc. gospodarstw, wyjścia do kina prawie 27 proc. gospodarstw i zakupu książki 11 proc. gospodarstw.

W latach 2007-2011 wzrósł znacząco odsetek gospodarstw domowych nieodczuwających potrzeby korzystania z każdej z analizowanych form uczestnictwa w kulturze (wykres 4.6.1). Najsilniejszy wzrost braku zainteresowania gospodarstw domowych rozważanymi formami uczestnictwa w kulturze dotyczył przy tym zakupu książki (wzrost o ponad 7 p.p), a najsłabszy zakupu prasy (wzrost o ponad 2 p.p). Natomiast w dwóch ostatnich latach zmiany częstości braku zainteresowania gospodarstw domowych wybranymi formami uczestnictwa w kulturze obserwujemy tylko w przypadku zakupu książki (wzrost o ponad 1 punkt procentowy). Wzrosła jednocześnie wśród badanych gospodarstw domowych potrzeba wyjścia do kina (o 1 punkt procentowy) (wykres 4.6.2).

Jeśli chodzi o grupę społeczno-ekonomiczną, najwięcej niezainteresowanych zakupem prasy jest wśród grupy gospodarstw utrzymujących się z niezarobkowych źródeł (prawie 14 proc. gospodarstw), a najmniej w grupie gospodarstw pracowników (niecałe 4 proc. gospodarstw). Zakupem książek najrzadziej zainteresowane są gospodarstwa rencistów (ponad 34 proc. gospodarstw deklaruje brak takiej potrzeby) i utrzymujących się z niezarobkowych źródeł (29 proc. gospodarstw), a najczęściej gospodarstwa pracujących na własny rachunek (tylko 4 proc. deklaruje brak potrzeby zakupu książek) i pracowników (ponad 8 proc. niezainteresowanych).

Teatrem, operą, operetką, filharmonią czy koncertem najczęściej niezainteresowane są gospodarstwa rencistów (ponad 61 proc. gospodarstw) rolników i emerytów (odpowiednio 54 proc. i prawie 53 proc. gospodarstw), a najrzadziej gospodarstwa pracujących na własny rachunek (niecałe 26 proc. gospodarstw) i pracowników (ponad 33 proc. gospodarstw). Podobne różnice dotyczą potrzeby zwiedzania muzeum lub wystawy i kina.

W przekroju typu gospodarstwa brak potrzeby uczestniczenia w kulturze zgłaszają najczęściej gospodarstwa nierodzinne (zarówno jednoosobowe, jak i wieloosobowe) i małżeństw bez dzieci, a najrzadziej małżeństw z dwójką dzieci.

Im mniejsza miejscowość tym częstszy brak potrzeb kulturalnych. Wyjątek stanowi prasa i książka, których zakupem interesują się mieszkańcy zarówno dużych miast, jak i małych miast i wsi. Niezbyt duże jest też terytorialne zróżnicowanie potrzeb kulturalnych. Z wyjątkiem prasy i książki, najmniej zainteresowane uczestnictwem w kulturze są gospodarstwa z województw wschodnich, a najbardziej mieszkańcy województw pomorskiego i wielkopolskiego.

$\mathrm{Na}$ uczestnictwo gospodarstw domowych w kulturze wskazuje pośrednio także między innymi wielkość księgozbiorów posiadanych przez gospodarstwa domowe. Wielkość księgozbioru utrzymuje się na podobnym poziomie od 2007 r. (tabela 4.6.1). Przybyło, co prawda, niewielkich zbiorów do 100 woluminów, ale ubyło zbiorów większych -- powyżej 100 woluminów.

Tabela 4.6.1. Odsetek gospodarstw domowych majacych określonq wielkość księgozbioru w 2007, 2009 i 2011 r.

\begin{tabular}{lrrr}
\hline Liczba woluminów & 2011 & 2009 & 2007 \\
\hline 0 & 12,5 & 12,8 & 10,1 \\
do 25 & 21,9 & 22,3 & 23,1 \\
$26-50$ & 22,1 & 21,6 & 21,5 \\
$51-100$ & 21,2 & 20,7 & 20,6 \\
$101-500$ & 16,9 & 17,2 & 19,8 \\
ponad 500 & 5,4 & 5,5 & 5,9 \\
\hline
\end{tabular}


Najczęściej deklaracje, że nie posiadają żadnych księgozbiorów, składały w marcu 2011 r. gospodarstwa domowe rencistów oraz utrzymujących się z niezarobkowych źródeł utrzymania (po ponad 27 proc. gospodarstw domowych w tych grupach społeczno-ekonomicznych). Najliczniejsze księgozbiory, powyżej 500 sztuk, posiadały natomiast gospodarstwa domowe pracujących na własny rachunek. W ostatnich dwóch latach znacząco zwiększył się odsetek gospodarstw domowych utrzymujących się z niezarobkowych źródeł deklarujących, że nie posiadają księgozbiorów (o ponad 3 p.p). Jednocześnie w tym samym okresie wzrósł odsetek gospodarstw domowych rolników oraz rencistów posiadających księgozbiory (odpowiednio o ponad 4 i o ponad 2 p.p).

Różnice w wielkości księgozbiorów pomiędzy grupami gospodarstw domowych bez bezrobotnych i z bezrobotnymi nie były znaczne. Odsetki gospodarstw domowych w tych grupach gospodarstw, nieposiadające księgozbiorów, nie uległy w ciągu ostatnich dwóch lat znaczącym zmianom.

Wśród wyróżnionych w badaniu typów gospodarstw domowych najczęściej nie posiadały w ogóle księgozbioru w marcu 2011 r. gospodarstwa domowe nierodzinne jednoosobowe (prawie 25 proc. gospodarstw z tej grupy). Najczęściej gospodarstwa o najliczniejszych księgozbiorach, o liczbie woluminów powyżej 500 sztuk, występowały wśród gospodarstw domowych małżeństw bezdzietnych i małżeństw z 1 dzieckiem (odpowiednio prawie 7 i ponad 6 proc. gospodarstw).

Gospodarstwa domowe wiejskie znacznie częściej nie posiadają księgozbiorów niż gospodarstwa domowe miejskie (od ponad 20 proc. gospodarstw wiejskich do niecałych 5 proc. gospodarstw zamieszkujących największe miasta). Zdecydowanie najczęściej gospodarstwa domowe posiadające najliczniejsze księgozbiory zamieszkiwały największe miasta (ponad 14 proc. gospodarstw domowych z tej grupy). Zmiany odsetka gospodarstw domowych nieposiadających księgozbiorów nie były $\mathrm{w}$ ostatnich latach istotne $\mathrm{w}$ żadnym $\mathrm{z}$ wyszczególnionych typów gospodarstw domowych i miejsc ich zamieszkania. Województwami, w których najczęściej gospodarstwa domowe nie posiadały księgozbiorów były w marcu 2011 r. gospodarstwa zamieszkujące województwa świętokrzyskie i lubelskie (odpowiednio ponad 20 i ponad 19 proc. gospodarstw z tych województw).

Najczęściej gospodarstwa domowe oceniały (ponad 79 proc. gospodarstw), że poziom zaspokojenia ich potrzeb związanych z kulturą, w ostatnich dwóch latach nie zmienił się. Natomiast prawie 17 proc. gospodarstw uważa, że sytuacja w tym obszarze pogorszyła się, a tylko niecałe 4 proc., że uległa poprawie. W porównaniu z marcem 2009 r. znacząco (o ponad 3 p.p) spadł odsetek gospodarstw domowych negatywnie oceniających zmiany zaspokojenia swoich potrzeb związanych z kulturą.

Najbardziej pesymistycznie oceniają w marcu 2011 r. zmiany zaspokojenia swoich potrzeb związanych z kulturą gospodarstwa domowe utrzymujących się z niezarobkowych źródeł (około 29 proc. odczuło pogorszenie się poziomu zaspokojenia swoich potrzeb związanych z kulturą). Wśród typów gospodarstw najgorzej oceniają zmiany rodziny niepełne (prawie 23 proc. negatywnych ocen). W grupie gospodarstw domowych $\mathrm{z}$ bezrobotnymi negatywne oceny dało prawie 25 proc., podczas gdy w grupie gospodarstw domowych bez bezrobotnych tylko ponad 15 proc. Negatywne oceny zmian zachodzących w poziomie zaspokojenia potrzeb związanych z kulturą najczęściej formułowały gospodarstwa domowe zamieszkujące największe miasta (prawie 22 proc. gospodarstw z tych miast). Najwyższy procent gospodarstw pesymistycznie oceniających zmiany poziomu zaspokojenia potrzeb w obszarze kultury występuje w województwach łódzkim, dolnośląskim i lubuskim (odpowiednio ponad 20 i po ponad 19 proc. gospodarstw z tych województw).

Wielkość księgozbioru, podobnie jak wcześniej omawiane formy uczestnictwa w kulturze, związana jest z dobrobytem materialnym (dochodami i wyposażeniem gospodarstw domowych) i ze skorelowanym $z$ nim poziomem cywilizacyjnym (liczbą nowoczesnych urządzeń komunikacyjnych). Ponieważ zarówno dobrobyt materialny, jak i poziom cywilizacyjny zależą od poziomu wykształcenia, można oczekiwać, że wiele form uczestniczenia w kulturze skorelowanych jest z poziomem wykształcenia członków gospodarstwa domowego. I tak $\mathrm{w}$ istocie jest (tabele 4.6.2, 4.6.3). Niemal we wszystkich gospodarstwach, których głowa ma wyższe wykształcenie, jest jakiś księgozbiór, najczęściej (33 proc.) o wielkości między 100 a 500 woluminów) i najrzadszy jest brak zainteresowania zakupem prasy, zakupem książek, wystawami, teatrem i kinem.

Nie oznacza to oczywiście, że osoby z niskimi wskaźnikami cywilizacyjnymi (niskim wykształceniu, niskich dochodach i słabym wyposażeniu gospodarstw domowych w nowoczesne technologie komunikacyjne) w ogóle nie uczestniczą w kulturze. Uczestniczą, ale niemal wyłączenie w jednej formie — poprzez oglądanie telewizji. Tabela 4.6.4. dowodzi, że zależność między stopniem wyposażenia gospodarstwa domowego w nowoczesne urządzenia komunikacyjne związane z kulturą a czasem poświęcanym przez domowników na oglądanie telewizji jest odwrotnie proporcjonalna. Przez ponad trzy godziny dziennie ogląda telewizję 31 proc. członków gospodarstw o najuboższym wyposażeniu, a 27 proc. członków gospodarstw o najbogatszym wyposażeniu. Z kolei mniej niż dwie godziny dziennie ogląda telewizję 47 proc. członków gospodarstw o najbogatszym wyposażeniu a 33 proc. członków gospodarstw o najuboższym wyposażeniu w urządzenia elektroniczne związane z kulturą. Taki sama, tyle że jeszcze silniejsza zależność dotyczy poziomu wykształcenia (tabela 4.6.5). Dwukrotnie większy odsetek osób z wykształceniem podstawowym i niższym w porównaniu z osobami z wykształceniem wyższym i policealnym ogląda telewizję ponad 3 godziny dziennie (odpowiednio 43 proc. i 20 proc.).

Tabela 4.6.2. Odsetek gospodarstw domowych posiadajacych określonq wielkość księgozbioru, wedtug poziomu wykształcenia głowy gospodarstwa 


\begin{tabular}{|c|c|c|c|c|c|c|}
\hline \multirow{2}{*}{$\begin{array}{l}\text { Poziom wykształcenia głowy } \\
\text { gospodarstwa domowego }\end{array}$} & \multicolumn{6}{|c|}{ Wielkość księgozbioru } \\
\hline & brak & do 25 sztuk & 26-50 sztuk & $51-100$ sztuk & $\begin{array}{l}101-500 \\
\text { sztuk }\end{array}$ & $\begin{array}{c}\text { ponad } 500 \\
\text { sztuk }\end{array}$ \\
\hline Podstawowe i niżej & 37,4 & 33,2 & 19,0 & 6,8 & 3,2 & ,5 \\
\hline Zasadnicze zawodowe/gimnazjum & 14,1 & 28,2 & 27,0 & 20,8 & 8,6 & 1,4 \\
\hline Średnie & 4,9 & 19,0 & 24,4 & 26,8 & 20,4 & 4,4 \\
\hline Wyższe i pomaturalne & 1,8 & 9,0 & 15,3 & 24,4 & 33,4 & 16,0 \\
\hline
\end{tabular}

Chi-kwadrat $=3762,459, \mathrm{df}=15, \mathrm{p}<0,000$.

Tabela 4.6.3. Odsetek gospodarstw niezainteresowanych różnymi formami uczestnictwa w kulturze ze względu na poziom wykształcenia głowy gospodarstwa w 2007, 2009 i $2011 \mathrm{r}$.

\begin{tabular}{|c|c|c|c|c|c|c|c|c|c|c|}
\hline \multirow{3}{*}{$\begin{array}{l}\text { Poziom wykształcenia głowy } \\
\text { gospodarstwa domowego }\end{array}$} & \multicolumn{10}{|c|}{ Brak zainteresowania } \\
\hline & \multicolumn{2}{|c|}{ kinem } & \multicolumn{2}{|c|}{ teatrem } & \multicolumn{2}{|c|}{ wystawami } & \multicolumn{2}{|c|}{$\begin{array}{c}\text { zakupem } \\
\text { książek }\end{array}$} & \multicolumn{2}{|c|}{ zakupem prasy } \\
\hline & 2011 & 2009 & 2011 & 2009 & 2011 & 2009 & 2011 & 2009 & 2011 & 2009 \\
\hline Podstawowe i niżej & 59,8 & 59,0 & 71,6 & 71,1 & 72,9 & 72,2 & 43,3 & 41,6 & 15,8 & 15,9 \\
\hline Zasadnicze zawodowe/gimnazjum & 27,4 & 32,8 & 48,0 & 52,6 & 51,5 & 53,1 & 17,9 & 18,1 & 5,9 & 6,1 \\
\hline Średnie & 20,3 & 21,2 & 36,3 & 36,8 & 38,4 & 37,6 & 10,0 & 9,0 & 4,2 & 3,4 \\
\hline Wyższe i pomaturalne & 8,9 & 9,2 & 20,5 & 19,3 & 21,9 & 20,2 & 4,0 & 3,2 & 2,9 & 2,0 \\
\hline
\end{tabular}

Tabela 4.6.4. Odsetek respondentów poświęcajacych różnq ilość czasu na oglądanie telewizji wedtug liczby urzqdzeń technicznych zwiqzanych z kulturq w ich gospodarstwach domowych

\begin{tabular}{lcccccc}
\hline $\begin{array}{c}\text { Liczba urządzeń technicznych } \\
\text { związanych z kulturą na } \\
\text { wyposażeniu gospodarstwa } \\
\text { domowego }\end{array}$ & \multicolumn{5}{c}{ Ilość czasu poświęcanego przeciętnie dziennie na oglądanie telewizji } \\
\cline { 2 - 7 } & nie oglądają & $\begin{array}{c}\text { mniej niż } \\
\text { godzinę }\end{array}$ & $\begin{array}{c}\text { od godziny } \\
\text { do dwóch } \\
\text { godzin }\end{array}$ & $\begin{array}{c}\text { od dwóch } \\
\text { do trzech } \\
\text { godzin }\end{array}$ & $\begin{array}{c}\text { od trzech do } \\
\text { czterech } \\
\text { godzin }\end{array}$ & $\begin{array}{c}\text { powyżej } \\
\text { czterech } \\
\text { godzin }\end{array}$ \\
\hline $0-2$ & 3,7 & 6,4 & 22,5 & 26,2 & 18,3 & 22,9 \\
$3-4$ & 4,5 & 10,2 & 28,4 & 25,2 & 15,1 & 16,6 \\
$5-7$ & 2,4 & 11,6 & 32,6 & 26,8 & 13,5 & 13,1 \\
Ogółem & 3,4 & 10,2 & 29,4 & 26,1 & 14,9 & 16,0 \\
\hline
\end{tabular}

Chi-kwadrat $=522,480, \mathrm{df}=10, \mathrm{p}<0,000$.

Tabela 4.6.5. Odsetek respondentów poświęcajacych różnq ilość czasu na ogladanie telewizji wedtug poziomu wyksztatcenia

\begin{tabular}{lcccccc}
\hline & \multicolumn{5}{c}{ Ilość czasu poświęcanego przeciętnie dziennie na oglądanie telewizji } \\
\cline { 2 - 7 } \multicolumn{1}{c}{ Poziom wykształcenia } & nie oglądają & $\begin{array}{c}\text { mniej niż } \\
\text { godzinę }\end{array}$ & $\begin{array}{c}\text { od godziny } \\
\text { do dwóch } \\
\text { godzin }\end{array}$ & $\begin{array}{c}\text { od dwóch } \\
\text { do trzech } \\
\text { godzin }\end{array}$ & $\begin{array}{c}\text { od trzech do } \\
\text { czterech } \\
\text { godzin }\end{array}$ & $\begin{array}{c}\text { powyżej } \\
\text { czterech } \\
\text { godzin }\end{array}$ \\
\hline Podstawowe i niżej & 2,7 & 6,4 & 23,4 & 24,6 & 19,1 & 23,7 \\
Zasadnicze zawodowe/gimnazjum & 2,4 & 8,6 & 28,5 & 27,1 & 15,8 & 17,6 \\
Średnie & 3,0 & 10,8 & 29,7 & 26,7 & 14,7 & 15,2 \\
Wyższe i pomaturalne & 6,0 & 14,6 & 34,5 & 24,7 & 10,8 & 9,3 \\
\hline
\end{tabular}

Chi-kwadrat $=907,811, \mathrm{df}=15, \mathrm{p}<0,000$

Także internet staje się coraz popularniejszym nośnikiem treści kulturalnych, zastępując papierowe wydania prasy czy koncerty (wykres 4.6.3).

Ogólnie, ograniczenia uczestnictwa w kulturze ze względu na brak środków finansowych, brak potrzeb związanych z tym uczestnictwem, ocena poziomu zaspokojenia potrzeb kulturalnych i wielkość księgozbioru zależą w głównej mierze od warunków materialnych, poziomu wykształcenia i poziomu cywilizacyjnego. Tylko telewizja $\mathrm{i}$ - w coraz większym stopniu - internet są powszechnie dostępnymi nośnikami treści kulturalnych; z telewizji więcej korzystają ci, którzy nie mają innych potrzeb kulturalnych (więcej na temat roli telewizji patrz rozdz. 5.11).

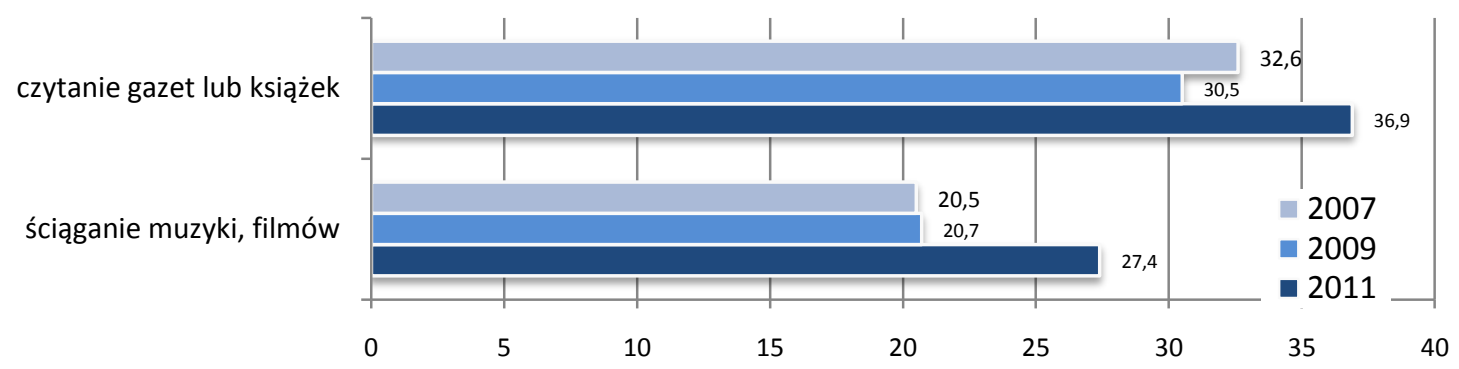

Wykres 4.6.3. Odsetek osób wykonujacych wybrane czynności $w$ internecie $w$ ostatnim tygodniu w latach 2007 i 2011 w próbie panelowej 


\subsubsection{Wypoczynek}

Tomasz Panek

Procent gospodarstw domowych zmuszonych w 2011 r. do rezygnacji z wyjazdów wypoczynkowych z powodów finansowych wahał się od ponad 38 proc. w przypadku wyjazdów grupowych dzieci (kolonii, obozów, itp.) do prawie 47 proc. dla wyjazdów dorosłych. Jednakże obserwujemy znaczącą poprawę w tym zakresie w stosunku do 2007 r. $^{44}$ (wykres 4.6.4). Spadek konieczności tego typu rezygnacji wyniósł od prawie 20 p.p. przy wyjazdach dorosłych do około 33 p.p. przy pozostałych typach wyjazdów.

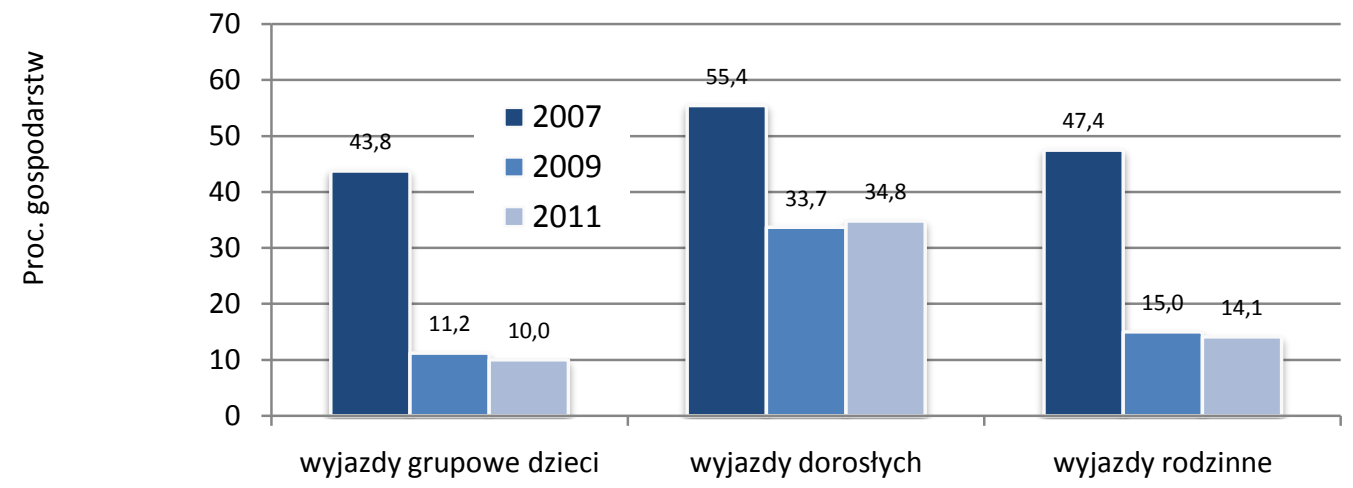

Formy wypocznyku

Wykres 4.6.4. Procent gospodarstw domowych zmuszonych do rezygnacji $z$ wybranych form wypoczynku w latach 2007-2011 w próbie panelowej.

W ostatnich dwóch latach nastąpił natomiast znaczący spadek konieczności rezygnacji ze względów finansowych z wyjazdów rodzinnych ${ }^{45}$ (o prawie 2 p.p, wykres 4.6.5).

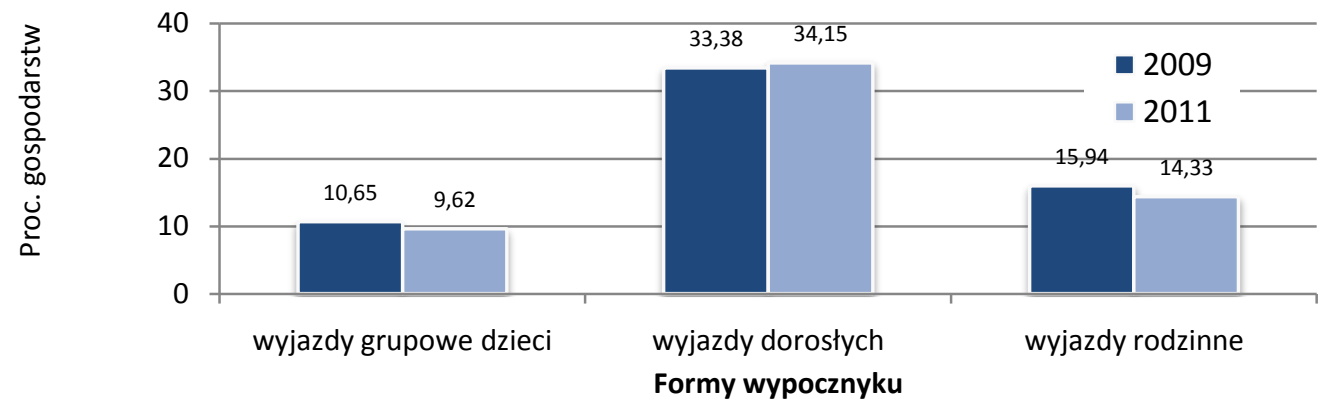

Wykres 4.6.5. Procent gospodarstw domowych zmuszonych do rezygnacji $z$ wybranych form wypoczynku $w 2009 i$ 2011 r. w próbie panelowej.

Rezygnacja ze względów finansowych w ostatniej kolejności z wyjazdów dzieci jest widoczna w 2011 r. prawie we wszystkich zastosowanych w badaniu klasyfikacjach gospodarstw domowych. Zdecydowanie najczęściej sytuacje rezygnacji z wyjazdów wypoczynkowych zdarzały się w gospodarstwach domowych utrzymujących się $\mathrm{z}$ niezarobkowych źródeł i rencistów (od ponad 70 proc. gospodarstw w przypadku wyjazdów dorosłych, do ponad 75 proc. gospodarstw w przypadku wyjazdów rodzinnych w pierwszej z grup gospodarstw oraz od ponad 69 proc. gospodarstw w przypadku wyjazdów grupowych dzieci do prawie 74 proc. gospodarstw w przypadku wyjazdów rodzinnych w drugiej z grup gospodarstw), a najrzadziej w gospodarstwach pracujących na własny rachunek (od ponad 21 proc. gospodarstw w przypadku wyjazdów grupowych dzieci, do prawie 29 proc. gospodarstw w przypadku wyjazdów dorosłych). Wzrost rezygnacji był znaczący w $2011 \mathrm{r}$. w porównaniu do $2009 \mathrm{r}$. w przypadku wyjazdów grupowych dzieci, wyjazdów dorosłych oraz wyjazdów rodzinnych tylko w grupie gospodarstw domowych utrzymujących się z niezarobkowych źródeł (odpowiednio o ponad 9, ponad 4 i prawie 10 p.p).

Do rezygnacji $\mathrm{z}$ wyjazdów ze względów finansowych najczęściej były zmuszane w 2011 r. gospodarstwa domowe małżeństw wielodzietnych i rodzin niepełnych (od prawie 51 proc. $z$ wyjazdów grupowych dzieci do około 61 proc. gospodarstw z wyjazdów dorosłych w pierwszej z grup gospodarstw oraz od prawie 53 proc. gospodarstw z wyjazdów grupowych dzieci do prawie 60 proc. gospodarstw z wyjazdów dorosłych w drugiej $\mathrm{z}$ grup). W ciagu

\footnotetext{
${ }^{44}$ Wszystkie zmiany w zakresie korzystania z wybranych form uczestnictwa w wypoczynku w latach 2007-2011 dotyczą próby panelowej z tych lat, czyli tych gospodarstw domowych, które zostały zbadane zarówno w 2007 r. jak i w 2009 r. i w 2011 r.

${ }^{45}$ Zmiany w zakresie korzystania $\mathrm{z}$ wybranych form uczestnictwa w wypoczynku w latach 2009-2011 dotyczą próby panelowej gospodarstw domowych $\mathrm{z}$ tych lat, czyli tych gospodarstw domowych, które zostały zbadane zarówno w 2009 r. jak i w 2011 r.
} 
ostatnich dwóch lat częstotliwość rezygnacji ze względów finansowych z wyjazdów wypoczynkowych zwiększyła się znacząco tylko w przypadku wyjazdów dorosłych w grupie gospodarstw domowych nierodzinnych jednoosobowych (o prawie 5 p.p).

Częstotliwość konieczności rezygnacji ze względów finansowych z wyjazdów była w 2011 r. znacznie wyższa $\mathrm{w}$ grupie gospodarstw $\mathrm{z}$ bezrobotnymi niż w grupie gospodarstw bez bezrobotnych (odpowiednio od prawie 62 proc. i około 34 proc. gospodarstw z wyjazdów grupowych oraz 67 proc. i około 44 proc. gospodarstw z wyjazdów dorosłych). W latach 2009-2011 w obu tych grupach gospodarstw zmniejszyła się częstotliwość rezygnacji z wyjazdów wypoczynkowych z wyjątkiem grupy gospodarstw domowych z bezrobotnymi w przypadku wyjazdów rodzinnych (wzrost rezygnacji o prawie 2 p.p).

Najwyższy procent gospodarstw zmuszonych do rezygnacji ze względów finansowych z wybranych form wypoczynku występował w 2011 r. na wsi. W przypadku wyjazdów dorosłych w gospodarstwach zamieszkujących wieś rezygnacje te dotyczyły prawie 58 proc. gospodarstw, a w odniesieniu do wyjazdów grupowych dzieci prawie 48 proc. gospodarstw. Najgorsza sytuacja pod względem rezygnacji z wyjazdów rodzinnych występowała w województwach warmińsko-mazurskim i podkarpackim (rezygnację z wyjazdów zgłosiło po prawie 51 proc. gospodarstw z tych województw), a z wyjazdów dorosłych także w województwie podkarpackim oraz łódzkim (zrezygnowało z wyjazdów odpowiednio ponad 56 proc. i ponad 55 proc. gospodarstw z tych województw). Najczęściej $\mathrm{z}$ wyjazdów dzieci musiały natomiast rezygnować gospodarstwa domowe w województwie podkarpackim (rezygnację zgłosiło prawie 57 proc. gospodarstw z tego województwa).

We wszystkich wyróżnionych w badaniu klasach miejscowości zamieszkania częstotliwość konieczności rezygnacji z wyjazdów wypoczynkowych spadła w porównaniu z 2009 rokiem, z wyjątkiem małych miast o liczbie mieszkańców 20-100 tys., w przypadku wyjazdów rodzinnych (wzrost rezygnacji o prawie 5 p.p) i najmniejszych miast w przypadku wyjazdów grupowych dzieci (wzrost rezygnacji o prawie 2 p.p). Znaczący wzrost rezygnacji z wyjazdów grupowych dzieci nastąpił w ostatnich dwóch latach w województwach podlaskim, dolnośląskim, podkarpackim i małopolskim (odpowiednio o ponad 16, prawie 7, prawie 5 i ponad 4 p.p), z wyjazdów dorosłych w województwach opolskim i dolnośląskim (odpowiednio o prawie 9 i o ponad 4 p.p), a z wyjazdów rodzinnych w województwach podlaskim, opolskim, pomorskim, warmińsko-mazurskim i wielkopolskim (odpowiednio o 19, ponad 10, ponad 8, prawie 5 i prawie 4 p.p).

Prawie 73 proc. gospodarstw domowych uważa, że zaspokojenie ich potrzeb związanych z wypoczynkiem w 2011 r. w porównaniu do sytuacji sprzed dwóch lat nie zmieniło się. Jednocześnie prawie 24 proc. gospodarstw wskazuje na pogorszenie się sytuacji w tym obszarze, a tylko niecałe 4 proc. na jej poprawę. Jest to jednak nieco lepiej niż przed dwoma laty (spadek negatywnych ocen o ponad 1 punkt procentowy). Najbardziej pesymistycznie oceniają zmiany gospodarstwa domowe utrzymujących się z niezarobkowych źródeł (ponad 35 proc. gospodarstw w tej grupie wystawiło negatywne oceny zmian). Wśród grup gospodarstw wyróżnionych ze względu na typ najgorzej oceniaja zmiany $\mathrm{w}$ zakresie zaspokojenia potrzeb związanych $\mathrm{z}$ wypoczynkiem gospodarstwa małżeństw wielodzietnych i rodzin niepełnych (po prawie 31 proc. ocen negatywnych). W grupie gospodarstw domowych z bezrobotnymi negatywne oceny zmian występowały znacznie częściej niż w grupie gospodarstw domowych bez bezrobotnych (odpowiednio w prawie 35 proc. i w ponad 22 proc. gospodarstw $\mathrm{z}$ tych grup). Negatywne oceny zmian zachodzących w poziomie zaspokojenia potrzeb w omawianym obszarze najczęściej formułowały gospodarstwa zamieszkujące największe miasta z ponad 500 tys. mieszkańców (prawie 28 proc. gospodarstw). Największy odsetek gospodarstw pesymistycznie oceniających zmiany w poziomie zaspokojenia potrzeb związanych z wypoczynkiem występuje w województwach łódzkim (prawie 30 proc. gospodarstw) i dolnośląskim (ponad 29 proc. gospodarstw). 


\title{
4.7. Opieka zdrowotna
}

\author{
Janusz Czapiński, Tomasz Panek
}

\subsubsection{Korzystanie z opieki zdrowotnej}

Według deklaracji gospodarstw domowych w marcu 2011 r. ponad 91 proc. z nich w ciagu ostatniego roku korzystało z placówek służby zdrowia opłacanych przez NFZ, ale też prawie połowa z nich korzystała z usług placówek, w których trzeba płacić z własnej kieszeni, i ponad 6 proc. z placówek opłacanych przez pracodawcę, który wykupił abonament lub ubezpieczenie. W porównaniu z poprzednimi latami wzrósł znacząco odsetek gospodarstw korzystających z abonamentu (tabela 4.7.1)

Tabela 4.7.1. Odsetek gospodarstw domowych korzystajacych z placówek opieki zdrowotnej wedtug źródła finansowania ustug

\begin{tabular}{llll}
\hline Rok badania & Środki publiczne & Środki prywatne & Abonamenty \\
\hline 2000 & 86,4 & 38,6 & 4,9 \\
2003 & 89,6 & 35,6 & 4,5 \\
2005 & 91,2 & 37,4 & 4,3 \\
2007 & 92,4 & 44,0 & 5,0 \\
2009 & 92,0 & 49,0 & 5,1 \\
2011 & 91,5 & 49,1 & 6,3 \\
\hline
\end{tabular}

W latach 2007-2011 ${ }^{46}$ znacząco wzrósł odsetek gospodarstw domowych korzystających z usług placówek, w których trzeba płacić z własnej kieszeni (o ok. 4 p.p., wykres 4.7.1) oraz nieznacznie spadł odsetek gospodarstw korzystających z placówek służby zdrowia opłacanych przez NFZ (o niecałe 2 p.p.).

Korzystanie przez gospodarstwa domowe z usług zdrowotnych opłacanych przez NFZ jest słabo zróżnicowane w różnych przekrojach społeczno-demograficznych (tabela 4.7.2). Wyróżniają się jedynie niższą częstością korzystania z takich usług gospodarstwa utrzymujące się z niezarobkowych źródeł oraz gospodarstwa nierodzinne, zarówno jedno- jak i wieloosobowe.

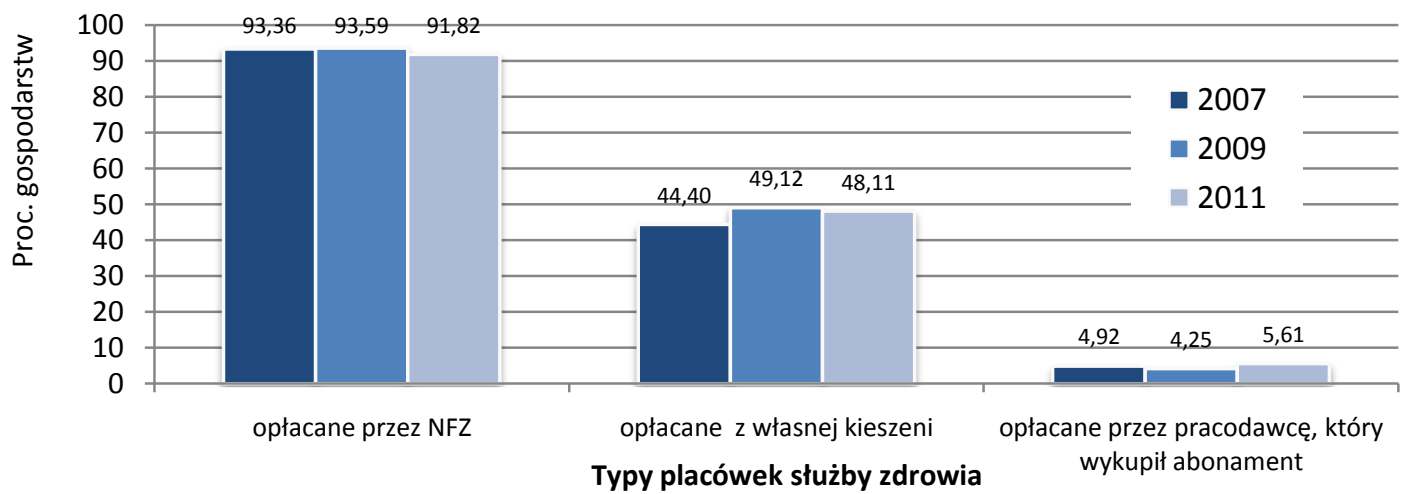

Wykres 4.7.1. Zakres korzystania przez gospodarstwa domowe z ustug placówek służby zdrowia w latach 2007-2011 w próbie panelowej.

Duże jest natomiast zróżnicowanie w zakresie korzystania z usług opłacanych przez same gospodarstwa. Najczęściej korzystają z nich gospodarstwa pracujących na własny rachunek (ponad 70 proc.), małżeństwa z 1 lub 2 dzieci (ok. 60 proc.), gospodarstwa z dochodem na jednostkę ekwiwalentną powyżej górnego kwartyla (ponad 2/3) i gospodarstwa zamieszkujące największe miasta (60 proc.), a najrzadziej płacą z własnej kieszeni za usługi zdrowotne gospodarstwa rencistów (29 proc.), emerytów (42 proc.), nierodzinne jednoosobowe (34 proc.), gospodarstwa $\mathrm{z}$ dochodem poniżej dolnego kwartyla (30 proc.) i gospodarstwa z woj. warmińsko-mazurskiego (27 proc.).

Z abonamentu korzystają najczęściej gospodarstwa domowe pracowników (11 proc.), małżeństwa z dziećmi (od 6 do 9 proc.) i przede wszystkim mieszkające w największych miastach (17 proc. ( wzrost w ostatnich 2 latach o 5 p.p.) i woj. mazowieckim (13 proc., głównie za sprawą mieszkańców Warszawy) oraz gospodarstwa z dochodem powyżej górnego kwartyla (14,5 proc.).

\footnotetext{
${ }^{46}$ Zmiany w zakresie opieki zdrowotnej w latach 2007-2011 dotyczą próby panelowej z tych lat, czyli tych gospodarstw domowych, które zostały zbadane zarówno w 2007 r. jak i w 2009 r. oraz 2011 r.
} 
Tabela 4.7.2. Odsetek gospodarstw domowych korzystajacych z ustug różnych placówek ochrony zdrowia w ciagu ostatniego roku

\begin{tabular}{|c|c|c|c|c|c|c|}
\hline \multirow[t]{2}{*}{ Grupa społeczno-demograficzna } & \multicolumn{2}{|c|}{ Opłacanych przez NFZ } & \multicolumn{2}{|c|}{$\begin{array}{c}\text { Opłacanych z własnej } \\
\text { kieszeni }\end{array}$} & \multicolumn{2}{|c|}{$\begin{array}{c}\text { Opłacanych przez } \\
\text { pracodawcę (abonament) }\end{array}$} \\
\hline & 2011 & 2009 & 2011 & 2009 & 2011 & 2009 \\
\hline \multicolumn{7}{|l|}{ Grupa społeczno-ekonomiczna } \\
\hline Pracownicy & 91,0 & 91,4 & 55,3 & 56,4 & 10,8 & 9,5 \\
\hline Rolnicy & 90,0 & 90,6 & 48,9 & 45,2 & - & - \\
\hline Pracujący na własny rachunek & 88,3 & 89,2 & 70,7 & 67,8 & 6,0 & 4,5 \\
\hline Emeryci & 93,9 & 93,7 & 42,1 & 39,6 & - & - \\
\hline Renciści & 94,3 & 94,7 & 28,6 & 29,7 & - & - \\
\hline Utrzymujący się z niezarobkowych źródeł & 82,8 & 87,1 & 29,0 & 36,3 & - & - \\
\hline \multicolumn{7}{|l|}{ Typ gospodarstwa domowego } \\
\hline $\begin{array}{l}\text { Jednorodzinne: } \\
\text { Małżeństwa bez dzieci }\end{array}$ & 92,7 & 93,5 & 52,1 & 52,6 & 6,4 & 5,4 \\
\hline Małżeństwa z 1 dzieckiem & 93,6 & 95,0 & 60,1 & 61,3 & 9,4 & 8,4 \\
\hline Małżeństwa z 2 dzieci & 93,7 & 94,2 & 59,4 & 61,2 & 9,3 & 7,6 \\
\hline Małżeństwa z 3 i więcej dzieci & 95,2 & 95,4 & 51,2 & 48,2 & 6,1 & 5,2 \\
\hline Rodziny niepełne & 92,0 & 93,3 & 41,7 & 40,5 & 4,5 & 3,3 \\
\hline Wielorodzinne & 95,3 & 96,0 & 53,3 & 53,0 & 5,8 & 3,3 \\
\hline $\begin{array}{l}\text { Nierodzinne: } \\
\text { Jednoosobowe }\end{array}$ & 85,4 & 84,9 & 33,8 & 33,3 & 3,2 & 2,3 \\
\hline Wieloosobowe & 88,7 & 85,1 & 39,7 & 40,5 & 0,7 & 3,3 \\
\hline \multicolumn{7}{|l|}{ Klasa miejscowości zamieszkania } \\
\hline Miasta powyżej 500 tys. & 90,1 & 88,1 & 59,8 & 58,7 & 16,9 & 11,9 \\
\hline Miasta $200-500$ tys. & 90,9 & 93,4 & 54,5 & 54,1 & 9,1 & 8,3 \\
\hline Miasta $100-200$ tys. & 92,0 & 92,8 & 46,1 & 47,9 & 6,4 & 4,8 \\
\hline Miasta 20-100 tys. & 92,2 & 92,6 & 49,8 & 49,6 & 4,7 & 4,4 \\
\hline Miasta poniżej 20 tys. & 91,5 & 92,3 & 44,4 & 45,7 & 4,0 & 3,3 \\
\hline Wieś & 91,9 & 92,2 & 44,8 & 43,8 & 2,8 & 2,2 \\
\hline \multicolumn{7}{|l|}{ Województwa } \\
\hline Dolnośląskie & 91,5 & 92,5 & 52,6 & 56,5 & 7,9 & 4,0 \\
\hline Kujawsko-pomorskie & 90,8 & 90,7 & 42,9 & 40,2 & 2,9 & 2,8 \\
\hline Lubelskie & 93,0 & 94,1 & 48,3 & 51,2 & 5,0 & 4,0 \\
\hline Lubuskie & 94,1 & 90,8 & 56,4 & 53,8 & 6,1 & 3,6 \\
\hline Łódzkie & 92,6 & 91,7 & 49,9 & 46,4 & 2,8 & 2,8 \\
\hline Małopolskie & 92,5 & 96,2 & 54,4 & 54,2 & 6,3 & 6,0 \\
\hline Mazowieckie & 89,3 & 87,7 & 52,4 & 53,1 & 13,0 & 10,4 \\
\hline Opolskie & 90,5 & 87,5 & 39,4 & 42,4 & 3,1 & 3,4 \\
\hline Podkarpackie & 95,2 & 96,0 & 56,7 & 54,4 & 2,6 & 3,5 \\
\hline Podlaskie & 93,1 & 92,3 & 50,2 & 46,5 & 2,8 & 3,0 \\
\hline Pomorskie & 91,6 & 93,2 & 52,2 & 52,6 & 9,7 & 10,4 \\
\hline Śląskie & 91,7 & 93,9 & 46,6 & 43,4 & 5,6 & 4,4 \\
\hline Świętokrzyskie & 89,1 & 91,0 & 47,4 & 48,2 & 3,1 & 2,1 \\
\hline Warmińsko-mazurskie & 90,0 & 91,1 & 27,3 & 26,4 & 1,9 &, 5 \\
\hline Wielkopolskie & 92,2 & 91,1 & 50,5 & 52,8 & 6,7 & 4,0 \\
\hline Zachodniopomorskie & 89,9 & 89,8 & 42,9 & 42,5 & 4,8 & 3,9 \\
\hline \multicolumn{7}{|l|}{ Dochód na osobę } \\
\hline Dolny kwartyl & 91,9 & 91,8 & 29,7 & 30,4 & 1,3 & 1,4 \\
\hline Środkowe 50 proc. & 93,2 & 94,0 & 48,9 & 49,0 & 4,6 & 3,3 \\
\hline Górny kwartyl & 88,2 & 89,1 & 68,1 & 65,5 & 14,5 & 11,6 \\
\hline Ogółem & 91,5 & 91,9 & 49,1 & 48,9 & 6,3 & 5,1 \\
\hline
\end{tabular}

- oznacza zbyt małą liczbę przypadków.

W szpitalu $\mathrm{z}$ powodów innych niż ciąża przebywał $\mathrm{W}$ minionym roku ktoś z członków co czwartego gospodarstwa domowego (tabela 4.7.3). Najczęściej były to gospodarstwa rencistów (31 proc.) i emerytów (28 proc.), a w przekroju typu gospodarstwa: wielorodzinne (34 proc.) oraz gospodarstwa małżeństw z 3 i większą liczbą dzieci. Klasa miejscowości zamieszkania i województwo słabiej różnicują korzystanie z opieki szpitalnej.

W porównaniu z poprzednią edycją Diagnozy częstość korzystania z opieki szpitalnej uległa niewielkim zmianom, zarówno ogólnie, jak i różnych przekrojach społeczno-demograficznych. 
Tabela 4.7.3. Odsetek gospodarstw domowych, których członek przebywał w ostatnim roku w szpitalu

\begin{tabular}{|c|c|c|}
\hline Grupa & 2011 & 2009 \\
\hline \multicolumn{3}{|l|}{ Grupa społeczno ekonomiczna } \\
\hline Pracownicy & 22,7 & 23,5 \\
\hline Rolnicy & 26,0 & 25,4 \\
\hline Pracujący na własny rachunek & 23,1 & 21,0 \\
\hline Emeryci & 28,0 & 28,3 \\
\hline Renciści & 31,0 & 32,0 \\
\hline Utrzymujący się z niezarobkowych źródeł & 22,3 & 21,1 \\
\hline \multicolumn{3}{|l|}{ Typ gospodarstwa domowego } \\
\hline \multicolumn{3}{|l|}{ Jednorodzinne: } \\
\hline Małżeństwa bez dzieci & 28,7 & 28,3 \\
\hline Małżeństwa z 1 dzieckiem & 24,7 & 25,6 \\
\hline Małżeństwa z 2 dzieci & 24,7 & 25,4 \\
\hline Małżeństwa z 3 i więcej dzieci & 28,5 & 30,5 \\
\hline Rodziny niepełne & 23,2 & 25,9 \\
\hline Wielorodzinne & 33,6 & 34,5 \\
\hline \multicolumn{3}{|l|}{ Nierodzinne: } \\
\hline Jednoosobowe & 19,9 & 19,4 \\
\hline Wieloosobowe & 23,3 & 17,4 \\
\hline \multicolumn{3}{|l|}{ Klasa miejscowości zamieszkania } \\
\hline Miasta powyżej 500 tys. & 23,8 & 22,0 \\
\hline Miasta 200-500 tys. & 25,0 & 24,7 \\
\hline Miasta $100-200$ tys. & 23,3 & 25,3 \\
\hline Miasta $20-100$ tys. & 25,2 & 24,6 \\
\hline Miasta poniżej 20 tys. & 25,8 & 26,0 \\
\hline Wieś & 25,4 & 27,1 \\
\hline \multicolumn{3}{|l|}{ Województwa } \\
\hline Dolnośląskie & 29,2 & 25,7 \\
\hline Kujawsko-pomorskie & 26,7 & 24,2 \\
\hline Lubelskie & 27,1 & 28,2 \\
\hline Lubuskie & 25,7 & 27,0 \\
\hline Łódzkie & 28,3 & 26,1 \\
\hline Małopolskie & 23,1 & 23,5 \\
\hline Mazowieckie & 23,8 & 25,1 \\
\hline Opolskie & 26,5 & 22,5 \\
\hline Podkarpackie & 26,3 & 28,3 \\
\hline Podlaskie & 29,1 & 28,2 \\
\hline Pomorskie & 19,9 & 23,5 \\
\hline Śląskie & 23,4 & 24,6 \\
\hline Świętokrzyskie & 28,8 & 25,0 \\
\hline Warmińsko-mazurskie & 18,4 & 24,2 \\
\hline Wielkopolskie & 26,0 & 26,6 \\
\hline Zachodniopomorskie & 20,7 & 23,8 \\
\hline Ogółem & 25,0 & 25,3 \\
\hline
\end{tabular}

\subsubsection{Rezygnacje $z$ opieki zdrowotnej}

Największa grupa gospodarstw domowych zmuszona była z powodu braku środków zrezygnować z leków i leczenia zębów (wykres 4.7.2). W 0,8 proc. gospodarstw zdarzyła się sytuacja, że rezygnowano z pobytu w szpitalu, ponieważ nie posiadano środków na opłacenie kosztów hospitalizacji. Znacznie większa grupa gospodarstw domowych zmuszona była z powodu braku środków finansowych zrezygnować z usług lekarza (14 proc.) i z badań medycznych (7,5 proc.). Nie pytaliśmy, czy w takiej sytuacji w ogóle rezygnowano $\mathrm{z}$ usług medycznych, czy jedynie z usług wymagających płacenia z własnej kieszeni (część pacjentów z tej grupy mogła przecież otrzymać świadczenia opłacane ze środków publicznych). Interesowała nas bowiem tutaj skala barier, na jakie napotykają gospodarstwa, które odczuwają jakieś subiektywne potrzeby zdrowotne i zaspokoiłyby je, gdyby miały na to prywatne środki w sektorze opłacanym prywatnie.

Skala rezygnacji z poszczególnych rodzajów usług medycznych z powodów finansowych była w $2011 \mathrm{r}$. niemal dokładnie taka sama jak dwa lata wcześniej. Nieznacznie tylko, w granicach 2 p.p, spadła skala rezygnacji z zakupu leków, wykonania protez zębowych i z sanatorium, a wzrosła w tych samych granicach skala rezygnacji z wizyt u lekarza.

Zakres rezygnacji z powodów finansowych z poszczególnych świadczeń zdrowotnych nie rozkłada się równo w przekroju grup społeczno-demograficznych Tabela 4.7.4). Biorąc pod uwagę tylko te gospodarstwa, które miały odpowiednie potrzeby, najwięcej rezygnacji z wszystkich lub większości świadczeń wystapiło w gospodarstwach utrzymujących się z niezarobkowych źródeł, rencistów, w rodzinach niepełnych, gospodarstwach nierodzinnych 
jedno- i wieloosobowych, w gospodarstwach zamieszkujących na wsi i w województwach łódzkim i świętokrzyskim.

Najrzadziej z wszelkich rodzajów usług zdrowotnych rezygnują gospodarstwa pracujących na własny rachunek, a najczęściej gospodarstwa rencistów i utrzymujących się ze źródeł niezarobkowych. Różnice ty wynikają głównie $\mathrm{z}$ różnic $\mathrm{w}$ poziomie zamożności.

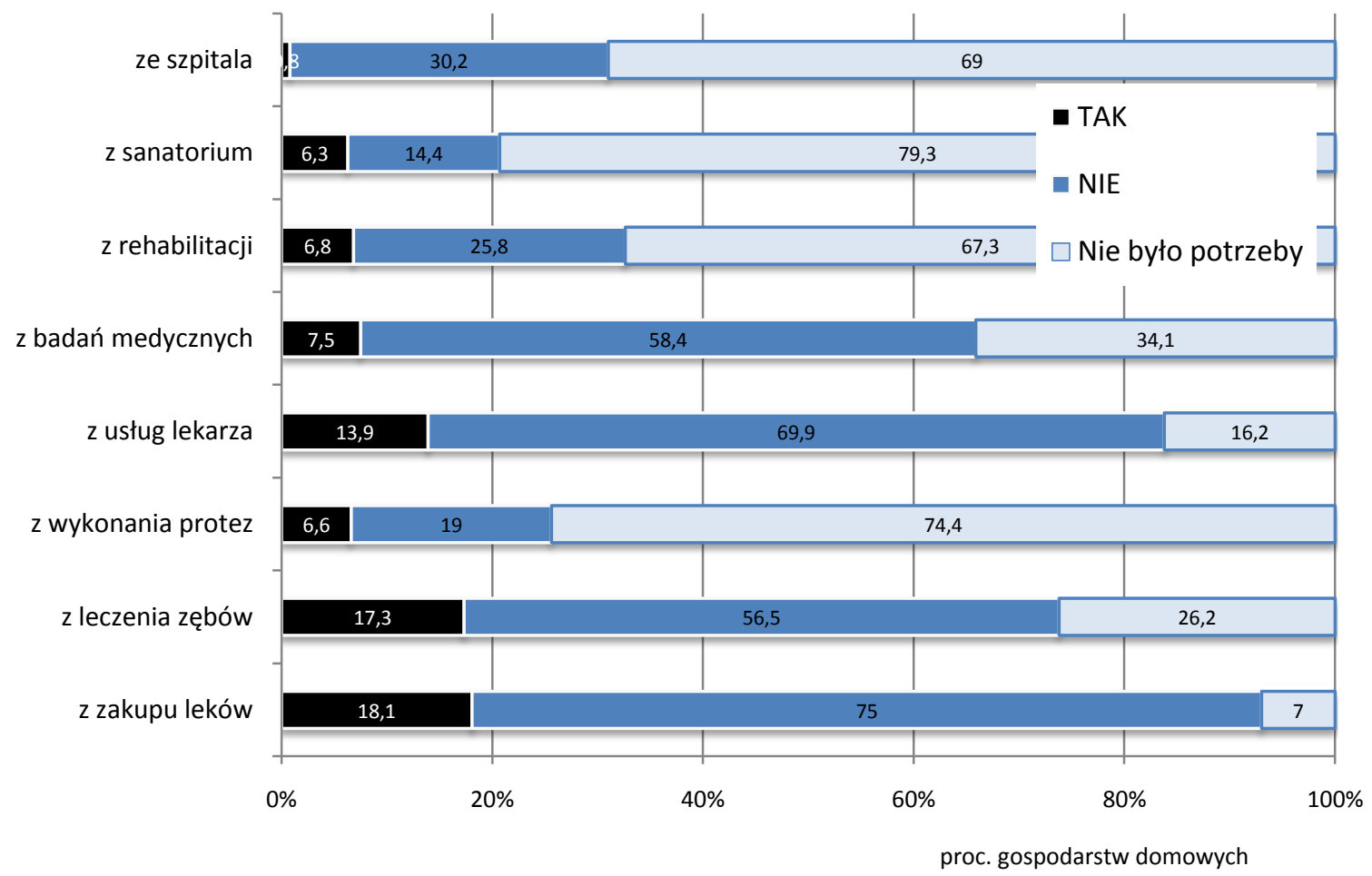

Wykres 4.7.2. Procent gospodarstw domowych, które zrezygnowaty z korzystania z wybranych rodzajów świadczeń zdrowotnych z powodu trudności finansowych

Rzadko też rezygnują małżeństwa z dziećmi, zwłaszcza z mniejszą liczbą dzieci. W małżeństwach z większą liczbą dzieci ( 3 i więcej) potrzeby zapewne są nie mniejsze, ale zasoby finansowe zdecydowanie mniejsze. Najwięcej rezygnacji w przekroju ze względu na typ gospodarstwa jest w rodzinach niepełnych, również uboższych od rodzin pełnych.

Więcej przeciętnie jest rezygnacji na wsi niż w miastach. I znów czynnikiem decydującym jest tutaj zamożność. W przekroju wojewódzkim nasilenie rezygnacji zależy od rodzaju usługi. Na przykład ze szpitala najczęściej rezygnują mieszkańcy woj. łódzkiego i małopolskiego, a najrzadziej woj. wielkopolskiego; z badań najczęściej rezygnuja gospodarstwa domowe z woj. łódzkiego, a najrzadziej mieszkańcy woj. opolskiego; z wizyt u lekarza najczęściej rezygnują gospodarstwa z woj. świętokrzyskiego, a najrzadziej mieszkańcy woj. opolskiego. 
Tabela 4.7.4. Odsetek gospodarstw domowych, które zrezygnowały z powodów finansowych z korzystania $z$ wybranych świadczeń zdrowotnych, mimo że ich potrzebowaty

\begin{tabular}{|c|c|c|c|c|c|c|c|c|}
\hline \multirow{2}{*}{ Grupa } & \multicolumn{8}{|c|}{ Procent gospodarstw domowych, które zrezygnowały z: } \\
\hline & $\begin{array}{l}\text { zakupu } \\
\text { leków }\end{array}$ & $\begin{array}{c}\text { leczenia } \\
\text { zębów }\end{array}$ & protez & $\begin{array}{l}\text { usług } \\
\text { lekarza }\end{array}$ & badań & $\begin{array}{c}\text { rehabili- } \\
\text { tacji }\end{array}$ & $\begin{array}{l}\text { sanato- } \\
\text { rium }\end{array}$ & szpitala \\
\hline \multicolumn{9}{|l|}{ Grupa społeczno ekonomiczna } \\
\hline Pracownicy & 14,6 & 21,1 & 21,1 & 13,4 & 8,8 & 17,7 & 22,9 & 2,0 \\
\hline Rolnicy & 14,3 & 23,1 & 19,6 & 11,6 & 8,6 & 17,2 & 29,2 & 0,9 \\
\hline Pracujący na własny rachunek & 5,3 & 11,3 & 19,2 & 6,0 & 4,4 & 11,4 & 10,6 & 1,3 \\
\hline Emeryci & 23,0 & 22,1 & 25,6 & 18,3 & 12,7 & 20,9 & 33,0 & 2,8 \\
\hline Renciści & 38,1 & 43,7 & 43,6 & 31,5 & 22,2 & 32,3 & 46,3 & 4,6 \\
\hline Utrzymujący się z niezarobkowych źródeł & 44,8 & 55,9 & 49,9 & 39,7 & 28,0 & 44,8 & 53,9 & 8,5 \\
\hline \multicolumn{9}{|l|}{ Typ gospodarstwa domowego } \\
\hline \multicolumn{8}{|l|}{ Małżeństwa bez dzieci } & 2,8 \\
\hline Małżeństwa z 1 dzieckiem & 13,9 & 18,9 & 21,6 & 12,3 & 9,7 & 17,0 & 26,4 & 1,9 \\
\hline Małżeństwa z 2 dzieci & 13,3 & 19,3 & 24,5 & 12,0 & 7,2 & 16,1 & 18,0 & 1,2 \\
\hline Małżeństwa z 3 i więcej dzieci & 23,8 & 32,3 & 32,2 & 20,0 & 14,0 & 23,9 & 33,8 & 1,4 \\
\hline Rodziny niepełne & 26,5 & 34,2 & 34,6 & 25,6 & 14,7 & 27,1 & 39,7 & 4,3 \\
\hline Wielorodzinne & 19,8 & 24,7 & 22,1 & 13,1 & 12,6 & 22,2 & 25,1 & 2,0 \\
\hline Nierodzinne: & 25,9 & 25,6 & 28,3 & 20,5 & 14,6 & 24,5 & 37,0 & 4,0 \\
\hline \multicolumn{9}{|l|}{ Jednoosobowe } \\
\hline Wieloosobowe & 22,2 & 24,9 & 31,7 & 28,9 & 17,8 & 26,6 & 29,8 & 2,8 \\
\hline \multicolumn{9}{|l|}{ Klasa miejscowości zamieszkania } \\
\hline Miasta powyżej 500 tys. & 15,4 & 20,5 & 20,2 & 15,3 & 12,1 & 17,9 & 24,9 & 3,3 \\
\hline Miasta 200-500 tys. & 17,1 & 20,0 & 29,4 & 14,4 & 10,3 & 25,3 & 30,6 & 3,0 \\
\hline Miasta $100-200$ tys. & 18,1 & 21,8 & 26,0 & 15,4 & 12,7 & 23,7 & 32,4 & 2,8 \\
\hline Miasta 20-100 tys. & 19,4 & 22,5 & 22,9 & 16,7 & 10,6 & 21,8 & 27,9 & 1,7 \\
\hline Miasta poniżej 20 tys. & 18,7 & 22,7 & 21,0 & 15,5 & 11,2 & 18,9 & 30,3 & 3,2 \\
\hline Wieś & 22,6 & 27,3 & 31,0 & 18,7 & 11,9 & 20,3 & 34,8 & 2,7 \\
\hline \multicolumn{9}{|l|}{ Województwa } \\
\hline Dolnośląskie & 22,5 & 28,1 & 27,0 & 20,7 & 15,2 & 26,3 & 29,9 & 3,3 \\
\hline Kujawsko-pomorskie & 17,8 & 19,8 & 19,4 & 12,0 & 9,0 & 18,7 & 25,3 & 3,1 \\
\hline Lubelskie & 23,9 & 28,3 & 29,9 & 16,1 & 13,5 & 19,5 & 30,9 & 1,3 \\
\hline Lubuskie & 21,1 & 31,2 & 30,7 & 19,2 & 12,7 & 24,2 & 41,8 & 3,9 \\
\hline Łódzkie & 24,7 & 27,5 & 26,0 & 20,8 & 19,3 & 27,0 & 41,4 & 5,3 \\
\hline Małopolskie & 18,0 & 20,1 & 19,3 & 15,7 & 8,9 & 15,9 & 25,8 & 5,2 \\
\hline Mazowieckie & 16,6 & 20,8 & 23,6 & 15,9 & 9,4 & 18,2 & 31,8 & 1,5 \\
\hline Opolskie & 19,5 & 19,8 & 24,9 & 13,0 & 5,1 & 18,9 & 21,1 & 1,2 \\
\hline Podkarpackie & 20,3 & 27,1 & 27,6 & 15,8 & 11,7 & 17,6 & 40,7 & 1,7 \\
\hline Podlaskie & 12,3 & 22,3 & 25,8 & 14,5 & 14,7 & 19,0 & 23,9 & 1,5 \\
\hline Pomorskie & 16,8 & 23,7 & 31,7 & 19,1 & 14,2 & 24,8 & 37,1 & 2,3 \\
\hline Śląskie & 19,3 & 20,8 & 24,4 & 14,0 & 9,1 & 22,4 & 25,0 & 1,9 \\
\hline Świętokrzyskie & 24,0 & 24,4 & 33,9 & 23,6 & 12,7 & 23,6 & 30,1 & 3,7 \\
\hline Warmińsko-mazurskie & 24,0 & 32,5 & 37,9 & 17,4 & 9,5 & 18,4 & 33,0 & 2,6 \\
\hline Wielkopolskie & 16,6 & 19,3 & 20,3 & 16,4 & 10,8 & 19,2 & 26,6 & 0,9 \\
\hline Zachodniopomorskie & 18,5 & 22,2 & 34,6 & 14,4 & 8,4 & 20,7 & 37,7 & 3,6 \\
\hline \multicolumn{9}{|l|}{ Dochód ekwiwalentny gospodarstwa } \\
\hline$<1$ kwartyla & 41,6 & 50,5 & 49,8 & 36,2 & 25,9 & 38,0 & 56,0 & 6,4 \\
\hline $1-2$ kwartyl & 22,8 & 27,2 & 28,8 & 18,1 & 12,8 & 24,5 & 34,6 & 1,9 \\
\hline $2-3$ kwartyl & 11,2 & 14,6 & 17,0 & 10,6 & 7,8 & 14,8 & 21,5 & 1,7 \\
\hline$>3$ kwartyla & 3,9 & 7,7 & 7,5 & 3,8 & 2,8 & 7,9 & 8,5 & 0,5 \\
\hline Ogółem & 19,4 & 23,4 & 25,8 & 16,6 & 11,4 & 20,9 & 30,6 & 2,6 \\
\hline
\end{tabular}

\subsubsection{Wydatki ponoszone przez gospodarstwa domowe na świadczenia medyczne}

Wcześniej stwierdziliśmy, że już niemal połowa gospodarstw ponosi jakieś wydatki na usługi zdrowotne z własnej kieszeni. Spójrzmy teraz, na co i w jakiej wysokości szły te pieniądze w okresie jednego tylko kwartału poprzedzającego badanie (tabela 4.7.5).

Przeciętnie najwięcej kosztowały gospodarstwa ponoszące dany rodzaj wydatków leczenie i badania ambulatoryjne (550 zł), w dalszej kolejności był zakup leków (375 zł); tzw. dowody wdzięczności, czyli „łapówki”, dzięki którym próbowano pozyskać lepszą czy szybszą (np. większe zainteresowanie problemami pacjenta, więcej troski o jego zdrowie, wybór lekarza operującego lub opiekującego się pacjentem w szpitalu, przyspieszenie usługi itp.) to średnio 311 zł. Przeciętna opłata w szpitalu publicznym nie przekraczała 300 zł, a wysokość szczerego dowodu wdzięczności wręczanego za już uzyskaną opiekę wyniosła średnio 142 zł. 
Tabela 4.7.5. Procent gospodarstw domowych ponoszacych w okresie jednego kwartału wydatki na ochronę zdrowia i przeciętna wysokość tych wydatków w latach 2007-2011 w całych próbach

\begin{tabular}{|c|c|c|c|c|c|c|c|c|c|c|c|c|c|c|c|}
\hline & \multicolumn{3}{|c|}{$\begin{array}{l}\text { Leki i artykuły } \\
\text { farmaceutyczne }\end{array}$} & \multicolumn{3}{|c|}{$\begin{array}{c}\text { Kupowanie usług w } \\
\text { zakresie } \\
\text { ambulatoryjnej } \\
\text { opieki zdrowotnej } \\
\end{array}$} & \multicolumn{3}{|c|}{$\begin{array}{c}\text { Opłaty nieformalne, } \\
\text { tzw. dowody } \\
\text { wdzięczności } \\
\text { (,łapówki”) }\end{array}$} & \multicolumn{3}{|c|}{$\begin{array}{l}\text { Prezenty jako } \\
\text { dowody szczerej } \\
\text { wdzięczności }\end{array}$} & \multicolumn{3}{|c|}{$\begin{array}{l}\text { Opłaty w szpitalu } \\
\text { publicznym }\end{array}$} \\
\hline & 2011 & 2009 & 2007 & 2011 & 2009 & 2007 & 2011 & 2009 & 2007 & 2011 & 2009 & 2007 & 2011 & 2009 & 2007 \\
\hline $\begin{array}{l}\text { Procent gospodarstw } \\
\text { ponoszących wydatki } \\
\text { danego rodzaju }\end{array}$ & 87 & 89 & 87 & 39 & 35 & 32 & 1,7 & 1,3 & 1,8 & 1,6 & 1,9 & 2,4 & 2,1 & 1,6 & 1,7 \\
\hline $\begin{array}{l}\text { Przeciętna wysokość } \\
\text { wydatków w zł }\end{array}$ & 375 & 379 & 307 & 550 & 524 & 384 & 311 & 308 & 265 & 142 & 136 & 114 & 285 & 198 & 119 \\
\hline
\end{tabular}

W porównaniu z wcześniejszym okresem wzrosły realnie jedynie opłaty w szpitalu publicznym. Inne wydatki, choć nominalnie wzrosły (np. prezenty, czy usługi ambulatoryjne), realnie pozostały na poziomie sprzed dwóch i czterech lat. Spadły (zarówno realnie, jak również nominalnie) koszty zakupu leków. Potwierdza to porównanie wydatków w próbie panelowej (wykres 4.7.3).

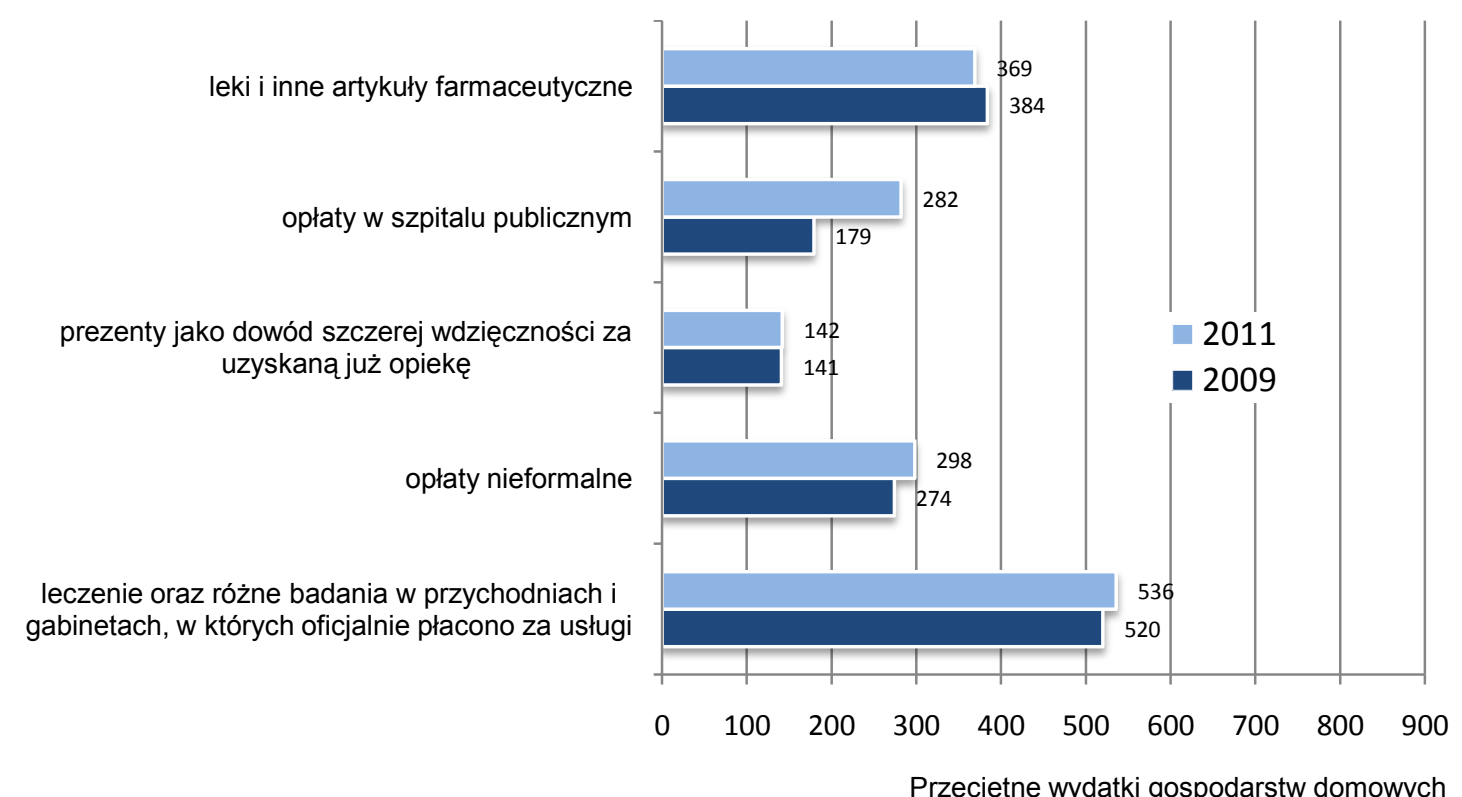

Wykres 4.7.3. Wydatki gospodarstw domowych zwiazanych z ochronq zdrowia $w$ ostatnich trzech miesiacach $w$ 2009 i 2011 r. w próbie panelowej.

Wysokość poszczególnych wydatków jest zróżnicowana w przekroju grup społeczno-demograficznych (tabela 4.7.6). Najwięcej na leczenie i badania wydawały gospodarstwa pracujących na własny rachunek, a na lekarstwa renciści. Rolnicy na usługi ambulatoryjne wydawali średnio tyle samo, co gospodarstwa emerytów, ale znacznie mniej od nich na lekarstwa. W przekroju typu gospodarstwa wydatki na opiekę ambulatoryjną i leki rozkładają się dosyć równomiernie, z wyjątkiem gospodarstw nierodzinnych, które w obu kategoriach ponoszą zdecydowanie mniejsze wydatki. W przekroju klasy miejscowości zamieszkania, najwięcej wydają przeciętnie mieszkańcy największych miast, a najmniej mieszkańcy małych miast i wsi. W przypadku opłat za usługi ambulatoryjne przoduje pod względem wydatków prywatnych województwo mazowieckie, a na przeciwnym krańcu jest woj. warmińsko-mazurskie (różnica trzykrotna). W wydatkach na leki przoduje woj. śląskie a najbardziej oszczędne jest ponownie woj. warmińsko-mazurskie. 
Tabela 4.7.6. Obciqżenie gospodarstw domowych wydatkami na leczenie i badania oraz na leki i inne artykuly farmaceutyczne wedtug grupy społeczno-ekonomicznej, typu gospodarstwa, klasy miejscowości zamieszkania, województwa i dochodu $w$ z $ł$ w catych próbach w 2009 i 2011 r. w grupie gospodarstw ponoszacych poszczególne kategorie kosztów (dane za 3 miesiqce)

\begin{tabular}{|c|c|c|c|c|}
\hline \multirow{3}{*}{ Grupa } & \multicolumn{4}{|c|}{ Wysokość wydatków (w zł) ponoszonych na: } \\
\hline & \multicolumn{2}{|c|}{ leczenie i różne badania } & \multicolumn{2}{|c|}{$\begin{array}{c}\text { leki i inne artykuły farmaceutyczne } \\
\text { związane z chorobą }\end{array}$} \\
\hline & 2011 & 2009 & 2011 & 2009 \\
\hline \multicolumn{5}{|l|}{ Grupa społeczno ekonomiczna } \\
\hline Pracownicy & 571 & 540 & 331 & 345 \\
\hline Rolnicy & 450 & 450 & 386 & 380 \\
\hline Pracujący na własny rachunek & 826 & 789 & 370 & 381 \\
\hline Emeryci & 466 & 473 & 436 & 450 \\
\hline Renciści & 389 & 398 & 484 & 390 \\
\hline Utrzymujący się z niezarobkowych źródeł & 460 & 311 & 265 & 253 \\
\hline \multicolumn{5}{|l|}{ Typ gospodarstwa domowego } \\
\hline \multicolumn{5}{|l|}{ Jednorodzinne: } \\
\hline Małżeństwa bez dzieci & 561 & 588 & 440 & 480 \\
\hline Małżeństwa z 1 dzieckiem & 563 & 495 & 371 & 372 \\
\hline Małżeństwa z 2 dzieci & 609 & 535 & 388 & 355 \\
\hline Małżeństwa z 3 i więcej dzieci & 587 & 604 & 361 & 350 \\
\hline Rodziny niepełne & 529 & 422 & 319 & 342 \\
\hline Wielorodzinne & 586 & 610 & 458 & 498 \\
\hline \multicolumn{5}{|l|}{ Nierodzinne: } \\
\hline Jednoosobowe & 427 & 467 & 323 & 318 \\
\hline Wieloosobowe & 395 & 294 & 284 & 306 \\
\hline \multicolumn{5}{|l|}{ Klasa miejscowości zamieszkania } \\
\hline Miasta powyżej 500 tys. & 772 & 727 & 411 & 423 \\
\hline Miasta $200-500$ tys. & 538 & 617 & 346 & 359 \\
\hline Miasta $100-200$ tys. & 514 & 475 & 444 & 363 \\
\hline Miasta 20-100 tys. & 487 & 445 & 367 & 388 \\
\hline Miasta poniżej 20 tys. & 564 & 484 & 360 & 371 \\
\hline Wieś & 480 & 457 & 367 & 370 \\
\hline \multicolumn{5}{|l|}{ Województwa } \\
\hline Dolnośląskie & 597 & 653 & 398 & 390 \\
\hline Kujawsko-pomorskie & 581 & 468 & 352 & 316 \\
\hline Lubelskie & 468 & 397 & 356 & 362 \\
\hline Lubuskie & 606 & 467 & 345 & 382 \\
\hline Łódzkie & 403 & 443 & 367 & 372 \\
\hline Małopolskie & 552 & 544 & 399 & 407 \\
\hline Mazowieckie & 768 & 686 & 389 & 433 \\
\hline Opolskie & 560 & 493 & 377 & 376 \\
\hline Podkarpackie & 470 & 354 & 369 & 357 \\
\hline Podlaskie & 453 & 690 & 354 & 378 \\
\hline Pomorskie & 529 & 539 & 335 & 341 \\
\hline Śląskie & 511 & 480 & 416 & 376 \\
\hline Świętokrzyskie & 480 & 378 & 343 & 382 \\
\hline Warmińsko-mazurskie & 264 & 293 & 280 & 300 \\
\hline Wielkopolskie & 578 & 504 & 415 & 406 \\
\hline Zachodniopomorskie & 526 & 559 & 315 & 353 \\
\hline \multicolumn{5}{|l|}{ Dochód ekwiwalentny gospodarstwa } \\
\hline 1 kwartyl & 406 & 364 & 324 & 331 \\
\hline 2 kwartyl & 463 & 453 & 410 & 384 \\
\hline 3 kwartyl & 502 & 474 & 377 & 389 \\
\hline 4 kwartyl & 718 & 690 & 387 & 409 \\
\hline Ogółem & 550 & 524 & 375 & 379 \\
\hline
\end{tabular}

\subsubsection{Ocena zmian w zaspokajaniu potrzeb zdrowotnych}

Mimo niesłabnącego narzekania na system ochrony zdrowia spada systematycznie odsetek negatywnych retrospektywnych ocen zmiany w stopniu zaspokojenia potrzeb zdrowotnych - z $41 \mathrm{w} 2000 \mathrm{r}$ do 26 obecnie (tabela 4.7.9). Nie rośnie jednak odsetek ocen pozytywnych, przybywa tylko liczby gospodarstw, które nie widzą zmian.

Negatywnych ocen zmian w zaspokojeniu potrzeb zdrowotnych w porównaniu do sytuacji w 2009 r. było znacznie więcej $\mathrm{w}$ grupie gospodarstw domowych $\mathrm{z}$ bezrobotnymi niż $\mathrm{w}$ grupie gospodarstw domowych bez bezrobotnych (odpowiednio prawie 31 i niecałe 25 proc. gospodarstw domowych dało oceny negatywne zmian). Najczęściej oceny negatywne tych zmian były formułowane, w przypadku wyróżnionych typów gospodarstw domowych, w grupach gospodarstw rodzin niepełnych i nierodzinnych jednoosobowych (w prawie 30 i prawie 29 
proc.). Gospodarstwa domowe najczęściej oceniające negatywnie zmiany w poziomie zaspokojenia ich potrzeb zdrowotnych zamieszkiwały w małych miastach o liczbie mieszkańców 20-100 tys. (około 27 proc.) oraz województwa warmińsko-mazurskie, łódzkie i świętokrzyskie (odpowiednio około 32 i po ponad 30 proc.).

Tabela 4.7.9. Ocena zmiany zaspokojenia potrzeb zdrowotnych w okresie minionych latach (od ostatniego pomiaru) w kolejnych rundach badania (w proc.)

\begin{tabular}{lrrrrrr}
\hline Zaspokajanie potrzeb zdrowotnych & \multicolumn{1}{c}{2000} & 2003 & 2005 & 2007 & 2009 & 2011 \\
\hline Pogorszyło się & 41 & 38 & 38 & 27 & 25 & 26 \\
Poprawiło się & 3 & 4 & 3 & 4 & 3 & 2 \\
Nie zmieniło sie & 57 & 58 & 59 & 69 & 72 & 72 \\
\hline
\end{tabular}




\title{
4.8. Analiza warunków życia gospodarstw domowych w układzie wojewódzkim
}

\author{
Tomasz Panek
}

\subsubsection{Porównanie poziomu warunków życia gospodarstw domowych}

Porównanie poziomu warunków życia gospodarstw domowych w układzie wojewódzkim zostało przeprowadzone w oparciu o taksonomiczną miarę warunków życia47. Warunki życia gospodarstw domowych były przy tym rozpatrywane przez pryzmat możliwości finansowych zaspokojenia ich potrzeb.

Taksonomiczna miara warunków życia jest wielkością syntetyczną, wypadkową oddziaływania wszystkich zmiennych (wskaźników) opisujących finansowe możliwości zaspokojenie potrzeb we wszystkich wyróżnionych w badaniu obszarach warunków życia w układzie wojewódzkim.

Warunki życia gospodarstw domowych w poszczególnych województwach są oceniane poprzez porównywanie wartości wyróżnionych zmiennych dla tych województw z wartościami tych zmiennych dla hipotetycznego województwa, czyli tzw. województwa wzorcowego.

Zmienne wykorzystywane w konstrukcji taksonomicznej miary warunków życia mają różny charakter, a mianowicie:

stymulant - zmienne, których większe wartości wskazują na lepsze warunki życia gospodarstw domowych w województwie,

destymulant - zmienne, których większe wartości wskazują na gorsze warunki życia gospodarstw domowych w województwie.

Punktem wyjścia konstrukcji taksonomicznej miary warunków życia jest wyznaczenie wartości zmiennych dla wzorowego województwa. Są to optymalne wartości poszczególnych zmiennych opisujących warunki życia gospodarstw domowych w województwach. Dla zmiennych stymulant są to wartości maksymalne, a dla zmiennych destymulant minimalne zaobserwowane wśród wszystkich porównywanych województw. Gdy analiza porównawcza dotyczy kilku okresów równocześnie, wartości optymalne są ustalone jako wartości najmniejsze lub największe wśród wszystkich porównywanych województw we wszystkich analizowanych okresach. Wzorcowe województwo stanowi tym samym pewien idealny wzorzec, z którym porównywane są poszczególne województwa. Formalnie rzecz biorąc, porównywane województwa oraz województwo wzorcowe reprezentowane są przez punkty w przestrzeni opisujących je zmiennych. Wymiar tej przestrzeni (liczba osi liczbowych określających ten wymiar) jest równy liczbie zmiennych opisujących warunki życia województw.

W następnym kroku procedury standaryzujemy wartości wyróżnionych zmiennych. Postępowanie takie umożliwia zarówno eliminację jednostek miary, jak i uniknięcie większego udziału zmiennych o wyższym poziomie w wartości liczbowej miary warunków życia.

Wartości syntetycznych miar warunków życia (podobnie jak grupowych miar warunków życia w poszczególnych ich dziedzinach) otrzymujemy przez obliczenie odległości poszczególnych punktów reprezentujących województwa od punktu reprezentującego wzorcowe województwo. Im lepsze warunki życia gospodarstw domowych w danym województwie tym mniejsza jest odległość reprezentującego go punktu od punktu reprezentującego wzorcowe województwo. Dzięki odpowiedniej normalizacji, zarówno grupowe miary warunków życia dla poszczególnych jego dziedzin, jak i syntetyczna miara warunków życia przyjmują zawsze wartości z przedziału [0;1]. Im lepsze warunki życia w województwie, tym odpowiadająca mu miara warunków życia przyjmuje mniejszą wartość (bliższą zeru). Czym gorsze warunki życia w województwie, tym odpowiednia miara warunków życia ma większą (bliższą jedności) wartość.

Analiza porównawcza warunków życia w układzie wojewódzkim była rozpatrywana, jak już wspomniano, pod kątem finansowych możliwości gospodarstw domowych zaspokojenia potrzeb w wybranych obszarach. Oznacza to, że na ocenę poziomu zaspokojenia niektórych potrzeb, szczególnie w obszarach kultury i wypoczynku, może także wpływać brak odczuwania tych potrzeb, co z kolei powoduje brak trudności finansowych w tym zakresie.

Województwami o najwyższym poziomie warunków życia (kolumna $10 \mathrm{w}$ tabeli 4.8.1) były w $2009 \mathrm{r}$. województwa mazowieckie, opolskie i wielkopolskie, a o najniższym warmińsko-mazurskie, łódzkie i dolnośląskie.

Hierarchia województw ze względu na poziom zaspokojenia potrzeb w poszczególnych obszarach warunków życia była zróżnicowana. W przypadku obszaru dochodów wyraźnie najlepsza sytuacja występowała w województwach mazowieckim, pomorskim i małopolskim, a najgorsza w województwach lubelskim, świętokrzyskim i podkarpackim.

W obszarze wyżywienia najwyższym poziomem zaspokojenia potrzeb charakteryzowały się województwa mazowieckie, wielkopolskie i śląskie, a najniższym łódzkie, warmińsko-mazurskie i dolnośląskie.

Potrzeby w zakresie zasobności materialnej były najwyżej zaspokojone w województwach podlaskim i małopolskim, a najniżej w województwach warmińsko-mazurskim i kujawsko-pomorskim.

Najwyższy poziom zaspokojenia potrzeb w zakresie warunków mieszkaniowych występował w województwach podkarpackim, mazowieckim i pomorskim, a najniższy w województwach świętokrzyskim i warmińsko-mazurskim.

\footnotetext{
47 Algorytm szacunku taksonomicznej miary warunków życia został przedstawiony w Aneksie 4.1. Taksonomiczna miara warunków życia została oparta na konstrukcji taksonomicznej miary rozwoju (por. np. Hellwig, 1968).
} 
W obszarze kształcenia dzieci najlepsza sytuacja występowała w województwach opolskim i wielkopolskim, a najgorsza w warmińsko-mazurskim, łódzkim, lubuskim.

Potrzeby w zakresie ochrony zdrowia na najwyższym poziomie były zaspokojone w województwach kojawskopomorskim i mazowieckim, a na najniższym w województwach dolnośląskim, łódzkim i lubuskim.

Najwyższym poziomem zaspokojenia potrzeb w zakresie uczestnictwa w kulturze charakteryzowały się województwa opolskie, kujawsko-pomorskie i wielkopolskie, a najniższym województwa łódzkie, dolnośląskie i pomorskie. W zakresie wypoczynku najwyższy poziom zaspokojenia potrzeb występuje w województwach śląskim, wielkopolskim i mazowieckim, a najniższy w województwach podlaskim i warmińsko-mazurskim.

Tabela 4.8.1. Warunki życia gospodarstw domowych $w$ układzie wojewódzkim $w 2011$ r. w porzqdku od najlepszych do najgorszych wedlug wielkości w kolumnie 10.

\begin{tabular}{|c|c|c|c|c|c|c|c|c|c|}
\hline \multirow[b]{2}{*}{ Województwo } & \multicolumn{9}{|c|}{ Obszary warunków życia } \\
\hline & Dochody & $\begin{array}{c}\text { Wyżywie- } \\
\text { nie }\end{array}$ & $\begin{array}{l}\text { Zasobność } \\
\text { materialna }\end{array}$ & $\begin{array}{l}\text { Warunki } \\
\text { mieszkanio- } \\
\text { we }\end{array}$ & $\begin{array}{l}\text { Kształcenie } \\
\text { dzieci }\end{array}$ & $\begin{array}{l}\text { Ochrona } \\
\text { zdrowia }\end{array}$ & $\begin{array}{l}\text { Uczestnictw } \\
\text { o w kulturze }\end{array}$ & $\begin{array}{l}\text { Wypoczy- } \\
\text { nek }\end{array}$ & Razem \\
\hline Mazowieckie & 0,000 & 0,162 & 0,504 & 0,132 & 0,560 & 0,237 & 0,377 & 0,194 & 0,290 \\
\hline Opolskie & 0,574 & 0,307 & 0,558 & 0,141 & 0,183 & 0,285 & 0,168 & 0,223 & 0,331 \\
\hline Wielkopolskie & 0,395 & 0,185 & 0,737 & 0,139 & 0,239 & 0,267 & 0,308 & 0,177 & 0,323 \\
\hline Śląskie & 0,422 & 0,192 & 0,731 & 0,612 & 0,267 & 0,336 & 0,409 & 0,130 & 0,459 \\
\hline Kujawsko-pomorskie & 0,553 & 0,430 & 0,764 & 0,152 & 0,576 & 0,229 & 0,306 & 0,343 & 0,492 \\
\hline Małopolskie & 0,333 & 0,349 & 0,469 & 0,622 & 0,595 & 0,240 & 0,697 & 0,364 & 0,539 \\
\hline Podlaskie & 0,562 & 0,499 & 0,386 & 0,157 & 0,523 & 0,375 & 0,437 & 0,662 & 0,543 \\
\hline Pomorskie & 0,296 & 0,502 & 0,597 & 0,134 & 0,371 & 0,497 & 0,728 & 0,629 & 0,569 \\
\hline Podkarpackie & 0,618 & 0,575 & 0,540 & 0,126 & 0,258 & 0,604 & 0,384 & 0,614 & 0,582 \\
\hline Zachodniopomorskie & 0,410 & 0,539 & 0,604 & 0,574 & 0,626 & 0,252 & 0,674 & 0,238 & 0,591 \\
\hline Lubelskie & 0,752 & 0,489 & 0,671 & 0,177 & 0,538 & 0,641 & 0,340 & 0,448 & 0,667 \\
\hline Świętokrzyskie & 0,699 & 0,577 & 0,470 & 0,626 & 0,598 & 0,643 & 0,345 & 0,403 & 0,677 \\
\hline Lubuskie & 0,468 & 0,582 & 0,743 & 0,170 & 0,673 & 0,665 & 0,405 & 0,635 & 0,700 \\
\hline Dolnośląskie & 0,360 & 0,619 & 0,704 & 0,620 & 0,579 & 0,688 & 0,732 & 0,628 & 0,732 \\
\hline Łódzkie & 0,553 & 0,779 & 0,746 & 0,149 & 0,682 & 0,685 & 0,739 & 0,538 & 0,736 \\
\hline Warmińsko-mazurskie & 0,580 & 0,691 & 0,810 & 0,624 & 0,691 & 0,589 & 0,391 & 0,662 & 0,755 \\
\hline
\end{tabular}

\subsubsection{Grupowanie województw ze względu na podobieństwo struktury warunków życia}

Zasadniczym celem grupowania województw było utworzenie grup województw jak najbardziej jednorodnych ze względu na strukturę warunków życia, opisywaną przez zmienne stanowiące oceny poziomu zaspokojenia potrzeb w poszczególnych obszarach warunków życia otrzymane w oparciu o taksonomiczną miarę warunków życia (por. tabela 4.8.1). Grupowania województw dokonano za pomocą metody $k$-średnich ${ }^{48}$ (Panek, 2009). Metoda ta maksymalizuje zróżnicowanie międzygrupowe województw oraz minimalizuje zróżnicowanie wewnątrz grup województw.

Punktem wyjścia metody $k$-średnich jest decyzja o liczbie, na które jest dzielona badana populacja województw. W przeprowadzonym badaniu przyjęto podział województw na 4 grupy. Wyodrębniono następujące grupy województw o podobnej strukturze warunków życia w 2011 r. (wykres 4.8.1):

grupa 1: kujawsko-pomorskie, mazowickie, opolskie i wielkopolskie,

grupa 2: lubelskie, lubuskie, łódzkie, podkarpackie, podlaskie i pomorskie,

grupa 3: małopolskie, śląskie i zachodnio-pomorskie,

grupa 4: dolnośląskie, świętokrzyskie i warmińsko-mazurskie.

Grupa 1 województw charakteryzuje się relatywnie najwyższym przeciętnym poziomem zaspokojenia potrzeb we wszystkich wyróżnionych obszarach warunków życia.

W grupie 2 województw obserwujemy najniższy przeciętny poziom zaspokojenia potrzeb w obszarze wypoczynku. Natomiast w pozostałych obszarach warunków życia przeciętne zaspokojenie potrzeb jest relatywne, poza obszarem warunków mieszkaniowych, także niskie.

W grupie 3 województwa były w 2011 r. relatywnie najsłabiej zaspokojone potrzeby w obszarze uczestnictwa w kulturze przy relatywnie wysokim przeciętnym, w stosunku do innych grup województw, poziomie zaspokojenia potrzeb w pozostałych analizowanych obszarach warunków życia. W przypadku zagospodarowania materialnego zaspokojenie potrzeb było w tej grupie województw nawet relatywnie najwyższe.

Wreszcie w grupie 4 województw relatywnie najsłabiej były zaspokojone potrzeby we wszystkich wyróżnionych obszarach warunków życia poza uczestnictwem w kulturze i wypoczynku.

\footnotetext{
${ }^{48}$ Opis metody $k$-średnich został przedstawiony w Aneksie 4.2.
} 


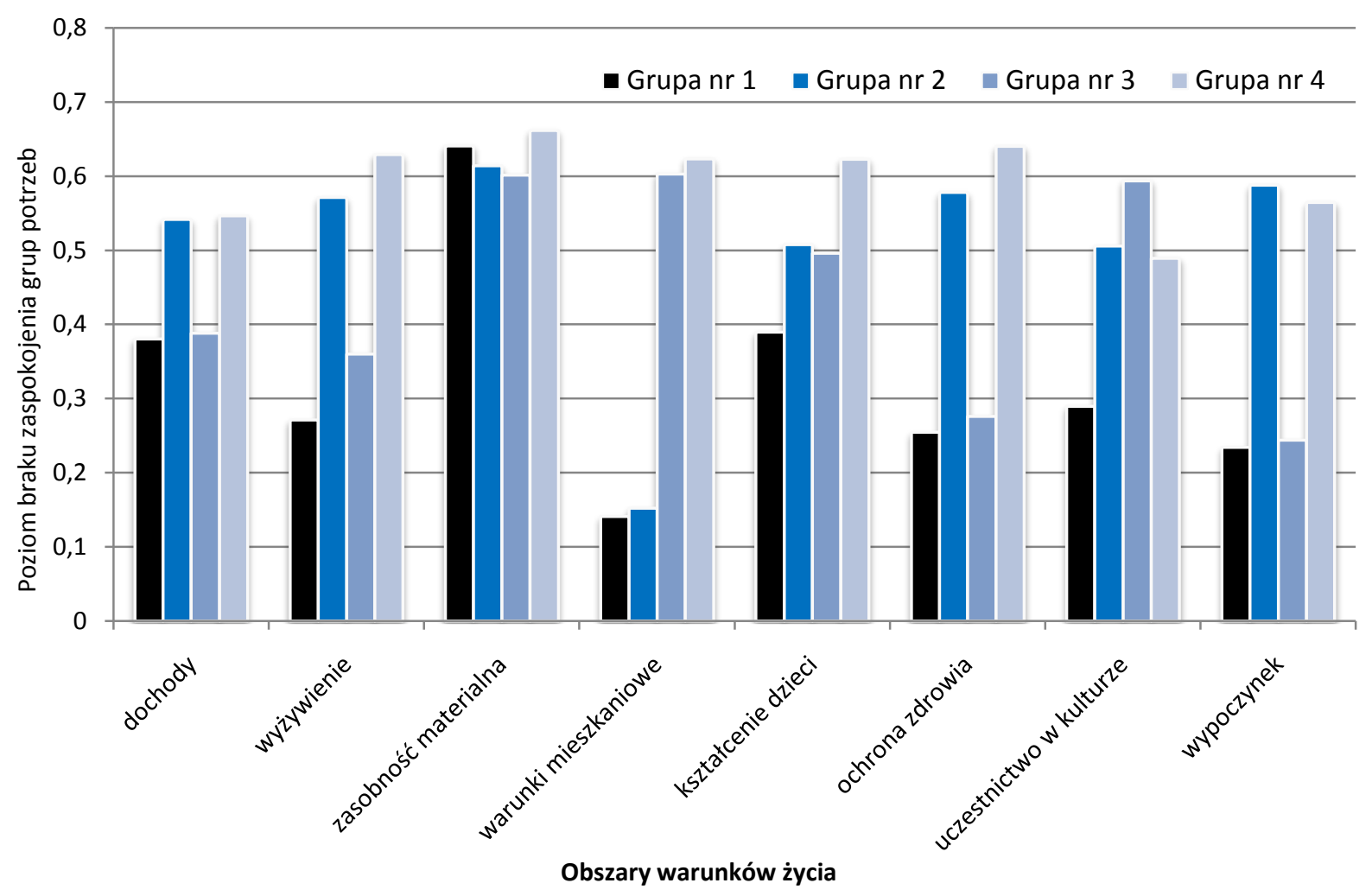

Wykres 4.8.1. Oceny warunków życia gospodarstw domowych dla grup województw w 2011 r. 


\subsection{Rynek pracy}

Pawel Strzelecki, Irena E. Kotowska

Spowolnienie wzrostu gospodarczego w Polsce było najbardziej odczuwalne pod koniec 2009 r., przyczyniając się do skokowej redukcji zatrudnienia oraz spadku popytu na pracę. Druga połowa 2010 roku i początek 2011 roku przyniosły zahamowanie zwolnień i stopniowe zwiększanie się popytu na pracę i liczby ofert pracy (GUS, 2011). Poza czynnikami ekonomicznymi w 2011 r. zmniejszyła się liczba ofert pracy dostępnych w urzędach pracy, co było częściowo związane $\mathrm{z}$ mniejszymi środkami na aktywne formy walki z bezrobociem (w tym dofinansowaniem tworzenia miejsc pracy). Najważniejszą strukturalną zmianą w latach 2009-2011 była kontynuacja niespotykanego od początku transformacji wzrostu aktywności zawodowej, zwłaszcza wśród osób w wieku 45-59 lat. ${ }^{49}$ Ważnym elementem zmian na polskim rynku pracy jest też stopniowy wzrost znaczenia umów na czas określony. Wydaje się jednak, że ocena tego zjawiska powinna być dokonana w kontekście oceny intensywności poszukiwania pracy i jej skuteczności zwłaszcza przez osoby młode.

Tym zagadnieniom poświecimy uwagę w niniejszym rozdziale. Najpierw przedstawione zostaną ogólne tendencje na rynku pracy w świetle wyników obecnej edycji Diagnozy Spolecznej. Następnie dokonamy szerszej analizy osób, które jednocześnie pracują na podstawie różnych form umów i poszukują innej pracy, a także zajmiemy się określeniem źródeł wzrostu aktywności zawodowej osób w wieku 45-59 lat. Ponadto, podobnie jak w poprzednim raporcie, odrębną część rozważań poświęcimy opiniom respondentów na temat rozwiązań sprzyjających godzeniu rodzicielstwa z aktywnością zawodową.

\subsubsection{Ogólne tendencje}

Porównanie wyników badania z 2009r. oraz 2011 r. przedstawia tabela 4.9.1. Pomimo spowolnienia gospodarczego wzrósł wskaźnik zatrudnienia, natomiast jednoczesny wzrost stopy bezrobocia był efektem wyraźnego wzrostu liczby osób aktywnych na rynku pracy (pracujących lub poszukujących pracy).

Wyniki Badania Aktywności Ekonomicznej Ludności (BAEL), które jest podstawowym źródłem danych o rynku pracy także pokazują te tendencje. Według BAEL wzrost wskaźnika zatrudnienia nastąpił jednak dopiero od drugiej połowy 2010 r. i zdążył jedynie wyrównać spadek, jaki nastąpił w związku ze spowolnieniem mającym apogeum pod koniec $2009 \mathrm{r}$.

Tabela 4.9.1. Podstawowe wskaźniki rynku pracy (w proc.) w badaniach Diagnozy Społecznej w latach 2000-2011

\begin{tabular}{|c|c|c|c|c|c|c|}
\hline Wskaźniki rynku pracy & 2000 & 2003 & 2005 & 2007 & 2009 & 2011 \\
\hline \multicolumn{7}{|c|}{ Wskaźniki rynku pracy Diagnoza Społeczna* } \\
\hline Stopa bezrobocia & 17,6 & 18,6 & 13,4 & 10,6 & 8,8 & 9,7 \\
\hline Współczynnik aktywności zawodowej & 61,3 & 56,8 & 56,8 & 56,3 & 56,3 & 58,3 \\
\hline Wskaźnik zatrudnienia & 50,5 & 46,2 & 49,3 & 50,4 & 51,3 & 52,6 \\
\hline \multicolumn{7}{|c|}{ Wskaźniki rynku pracy BAEL (II kw. każdego roku) } \\
\hline Stopa bezrobocia & 16,3 & 19,4 & 18,1 & 9,6 & 7,9 & 9,5 \\
\hline Współczynnik aktywności zawodowej & 56,4 & 54,6 & 54,5 & 53,5 & 54,7 & 55,6 \\
\hline Wskaźnik zatrudnienia & 47,2 & 44,0 & 44,6 & 18,3 & 50,4 & 50,7 \\
\hline
\end{tabular}

*Wskaźniki rynku pracy z Diagnozy Społecznej obliczone w sposób porównywalny z BAEL;. stopa bezrobocia obliczona dla grupy osób 15 i więcej lat w oparciu o definicję Międzynarodowej Organizacji Pracy.

Zgodnie z danymi o aktywności członków gospodarstw domowych wzrost bezrobocia był zapewne mniej odczuwalny w skali całych gospodarstw domowych niż wynikałoby to z tendencji ocenianej na postawie danych indywidualnych (tabela 4.9.2). W porównaniu z badaniem w 2009 r. wzrost liczby bezrobotnych nastąpił w gospodarstwach, w których inni członkowie mieli pracę zapewniającą dochód. Kontynuowana była natomiast tendencja systematycznego spadku odsetka gospodarstw domowych, w których wszyscy aktywni na rynku pracy członkowie bezskutecznie poszukiwali pracy (około 3 proc. w 2011r.).Wzrost aktywności zawodowej spowodował ponadto, że spadła liczba gospodarstw domowych, w których żaden z członków nie uczestniczył w rynku pracy (do blisko 18 proc.)

Analiza zmian ogólnej struktury zawodów osób pracujących wskazuje na systematyczny wzrost udziału specjalistów oraz spadek udziału pracowników biurowych, co potwierdza hipotezę redukowania roli zawodów związanych z obsługą biurową przez postęp technologiczny (tabela 4.9.3). Zmniejsza się też udział osób pracujących w rolnictwie w efekcie restrukturyzacji polskiego rolnictwa. Recesja, która dotknęła partnerów handlowych Polski, odbiła się w pierwszym rzędzie na przedsiębiorstwach eksportujących. One zmniejszały zatrudnienie w największym stopniu, co może tłumaczyć spadek udziału osób na stanowiskach robotniczych wśród ogółu pracujących. Spowolnienie gospodarcze było relatywnie najmniej odczuwalne w sektorze usług i tym tłumaczyć można istotny wzrost w 2011 r. odsetka osób pracujących w usługach osobistych.

\footnotetext{
${ }^{49}$ Więcej o zmianach na polskim rynku pracy znaleźć można w (Cichocki, Pawel Strzelecki, Tyrowicz, \& Wyszynski, 2011)
} 
Tabela 4.9.2. Udział osób z gospodarstw domowych sklasyfikowanych wedtug aktywności zawodowej ich członków $w$ latach 2003-2011*

\begin{tabular}{lcccccc}
\hline \multicolumn{1}{c}{ Grupy gospodarstw domowych } & 2003 & 2005 & 2007 & 2009 & 2011 \\
\hline Bez osób bezrobotnych oraz pracujących & 15,6 & 19,9 & 17,3 & & 19,3 & 17,8 \\
Z osobami bezrobotnymi, bez osób pracujących & 6,9 & 5,4 & 3,3 & 3,2 & 2,9 \\
Bez osób bezrobotnych, z osobami pracującymi & 57,7 & 60,4 & 67,7 & 68,1 & 67,3 \\
Z osobami bezrobotnymi i z osobami pracującymi & 19,7 & 14,2 & 11,7 & 9,4 & 12,0 \\
\hline *Brano pod uwage zarejestrowanych bezrobotnych.
\end{tabular}

*Brano pod uwage zarejestrowanych bezrobotnych.

Tabela 4.9.3. Struktura osób pracujacych wedtug grup zawodów w latach 2005-2011 (w proc.)

\begin{tabular}{|c|c|c|c|c|}
\hline Grupy zawodów & 2005 & 2007 & 2009 & 2011 \\
\hline Menedżerowie, kierownicy, wyżsi urzędnicy & 5,1 & 5,5 & 5,7 & 5,1 \\
\hline Specjaliści & 14,3 & 15 & 16,5 & 17,9 \\
\hline Technicy i personel pośredni & 12,7 & 11,1 & 11,7 & 10,5 \\
\hline Pracownicy biurowi & 8,2 & 7,6 & 7,5 & 7,3 \\
\hline Pracownicy usług osobistych, sprzedawcy & 12,8 & 12,5 & 11,5 & 13,3 \\
\hline Rolnicy, ogrodnicy, leśnicy, rybacy & 14,4 & 13,3 & 12,8 & 11,5 \\
\hline Robotnicy przemysłowi, rzemieślnicy & 16 & 17,5 & 18 & 16,2 \\
\hline Operatorzy i monterzy maszyn & 8,6 & 8,3 & 8,8 & 10,3 \\
\hline Pracownicy przy pracach prostych & 7,9 & 9,1 & 7,6 & 8,0 \\
\hline
\end{tabular}

W porównaniu do wyników z 2009 r. nie zmieniły się znacząco proporcje zawodów wśród osób bezrobotnych. Wciąż najwięcej osób bezrobotnych rekrutuje się spośród robotników, pracowników przy pracach prostych oraz także pracowników usług osobistych ze względu na stosowaną przez pracodawców wysoką rotację kadr (tabela 4.9.4). Nowością w stosunku do 2009 r., która wiąże się zapewne z osłabieniem popytu na pracę i wyższą podażą pracy osób o wysokich kwalifikacjach z dobrze wykształconego pokolenia wyżu demograficznego, był wzrost wśród bezrobotnych udziału osób, które poprzednio pracowały w zawodach wymagających kwalifikacji takich jak kadra kierownicza oraz specjaliści.

Tabela 4.9.4. Struktura bezrobotnych wedtug ostatnio wykonywanego zawodu w latach 2005-2011 (w proc bezrobotnych, którzy wcześniej pracowali)

\begin{tabular}{lcccc}
\hline \multicolumn{1}{c}{ Zawód ostatnio wykonywany } & 2005 & 2007 & 2009 & 2011 \\
\hline Menedżerowie, kierownicy, wyżsi urzędnicy & 1,8 & 1,7 & 0,5 & 1,3 \\
Specjaliści & 3,5 & 3,0 & 3,0 & 6,1 \\
Technicy i personel pośredni & 9,1 & 6,3 & 7,2 & 6,3 \\
Pracownicy biurowi & 8,3 & 11,1 & 8,2 & 10,2 \\
Pracownicy usług osobistych, sprzedawcy & 15,7 & 23,6 & 20,1 & 21,9 \\
Rolnictwo, ogrodnictwo, leśnictwo, rybołówstwo & 2,9 & 3,9 & 1,4 & 1,3 \\
Robotnicy przemysłowi, rzemieślnicy & 30,5 & 21,8 & 29,4 & 23,8 \\
Operatorzy i monterzy maszyn & 9,6 & 8,9 & 8,5 & 6,8 \\
Pracownicy przy pracach prostych & 18,6 & 19,6 & 21,6 & 22,2 \\
\hline
\end{tabular}

Porównanie bezrobocia rejestrowanego z bezrobotnymi według definicji BAEL prowadzi do wniosku, że od 2007 r. wśród osób zarejestrowanych odsetek tych, które naprawdę szukają pracy i są gotowe ją podjąć, jest zbliżony do 60\% (tabela 4.9.5). Dane z 2011 r. wskazują natomiast na kontynuację spadku odsetka osób zarejestrowanych w urzędach pracy, które nie poszukują pracy. W 2007 r. osoby takie stanowiły ponad 38 proc. ogółu zarejestrowanych bezrobotnych, w 2009 r. - 30 proc., natomiast w 2011 r. - około 24 proc. Z drugiej strony systematycznie rośnie odsetek osób deklarujących jednocześnie pracę i zarejestrowanie w urzędzie pracy (do 14 proc.), co można wiązać albo z szarą strefą albo z błędami klasyfikacji ze względu na wielość miejsc aktywizacji (bezrobotni skierowani w 2009r. i 2010 r. do miejsc aktywizacji zawodowej przez urzędy pracy byli formalnie wyrejestrowani z urzędów pracy, ale w kwestionariuszach ankietowych mogli przypuszczalnie wiązać swoją obecną aktywność zawodową z poprzednią rejestracją w urzędzie pracy).

Tabela 4.9.5. Bezrobocie a rejestracja $w$ urzędach pracy $w$ latach 2003-2011 (bezrobotni rejestrowani ogółem $w$ danym roku $=100$ )

\begin{tabular}{|c|c|c|c|c|c|}
\hline Grupy osób wyróżnione ze względu na definicję bezrobotnego & 2003 & 2005 & 2007 & 2009 & 2011 \\
\hline Osoby zarejestrowane i spełniające definicję bezrobotnego BAEL* & 69,9 & 56,6 & 60,6 & 62,0 & 61,9 \\
\hline Osoby zarejestrowane, ale nieposzukujące pracy & 21,3 & 31,9 & 38,6 & 30,1 & 23,7 \\
\hline Osoby zarejestrowane, ale pracujące zarobkowo & 8,8 & 11,5 & 0,8 & 7,9 & 14,4 \\
\hline Osoby niezarejestrowane, ale spełniające definicję bezrobotnego BAEL* & 17,0 & 24,6 & 27,6 & 29,1 & 21,7 \\
\hline
\end{tabular}

*definicja bezrobotnego BAEL nie zależy od rejestracji i obejmuje osoby nieposiadające pracy, poszukujące pracy i mogące ją podjąć w kolejnym tygodniu badania. 


\subsubsection{Poszukiwanie pracy i rodzaje kontraktów}

Osoby bezrobotne nie są jedynymi, które poszukują pracy. Według danych Diagnozy Społecznej 2011 bezrobotni zarejestrowani aktywnie poszukujący pracy to około 44 proc. wszystkich poszukujących pracy (wykres 4.9.1). Kolejne 16 proc. to osoby nierejestrujące się w urzędach pracy, ale poszukujące pracy i mogące natychmiast podjąć zatrudnienie. Ponadto około 40 proc. poszukujących pracy to nie są osoby bezrobotne. O tym, że granica między bezrobociem a biernością zawodową jest płynna, świadczy fakt, iż niektóre osoby pomimo pozostawania poza rynkiem pracy poszukują pracy, choć nie od razu mogłyby ją podjąć. Stanowią one 7 proc. wszystkich poszukujących pracy. Niektóre badania wskazują, że osoby „czekające” poza rynkiem pracy na atrakcyjne dla nich oferty wyraźnie wyróżniają się na tle innych osób nieaktywnych i ich zachowanie także może wpływać na rynek pracy (Jones \& Riddell, 1999) i powinno być brane pod uwagę w analizach rynku pracy. Ponadto znaczącym zjawiskiem jest także poszukiwanie innej pracy przez już pracujące osoby - takie osoby stanowią 33 proc. wszystkich poszukujących pracy.

Ciekawym zagadnieniem wydają się powody różnicujące nasilenie poszukiwania pracy pomimo jej posiadania. Wydaje się, że są one uzależnione od indywidualnej sytuacji na rynku pracy. Z jednej strony osoby o stabilnej pozycji zawodowej, które poszukują alternatywnych propozycji zatrudnienia, mogą kierować się chęcią znalezienia pracy na lepszych warunkach (lepiej wynagradzanej lub bardziej stabilnej). Z drugiej strony osoby o niestabilnej sytuacji zawodowej bardzo często są zmuszone szukać innej pracy ze względu na ograniczoną długość dotychczasowego kontraktu. Dane Diagnozy Społecznej wskazują, że wśród osób pracujących udział osób poszukujących innej pracy wynosi około 4-6 proc., przy czym odsetek ten wzrósł w ostatnich latach (wykres 4.9.2).

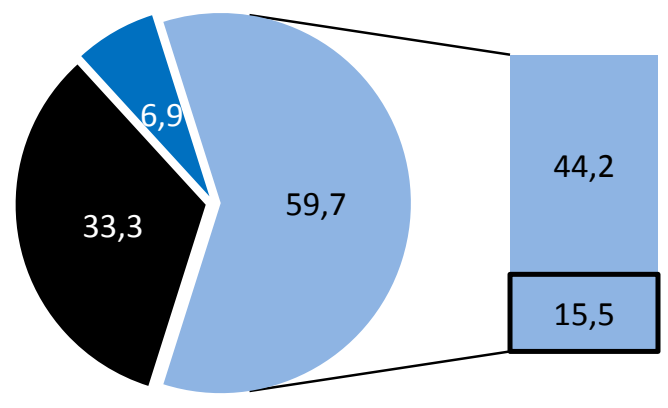

Poszukujący innej pracy

Nieaktywni

Bezrobotni zarejestrowani

Bezrobotni niezarejestrowani

Wykres 4.9.1. Struktura osób poszukujacych pracy w 2011 r. (w proc. ogółu osób poszukujacych pracy)

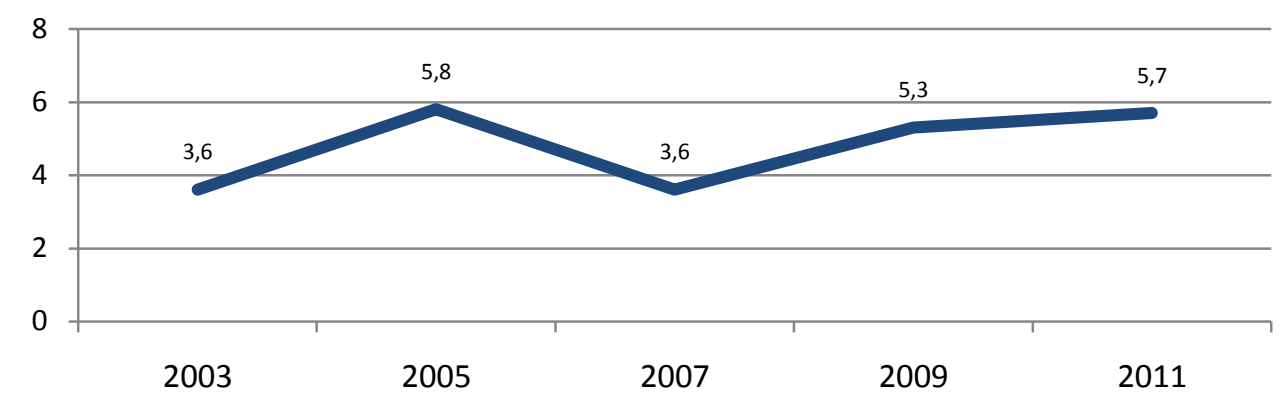

Wykres 4.9.2. Osoby pracujace poszukujace pracy (w proc. osób pracujacych)

Odwołując się do danych Diagnozy Społecznej 2011, można potwierdzić, że niepewność zatrudnienia jest najważniejszym czynnikiem zwiększającym udział osób poszukujących pracy wśród pracujących. Ranking najmniej stabilnych form zatrudnienia odzwierciedla jednocześnie skłonność do poszukiwania dodatkowego zatrudnienia (wykres 4.9.3). Wśród osób pracujących dorywczo na podstawie różnego typu umów cywilno-prawnych lub krótkoterminowych kontraktów, a nawet bez formalnej umowy odsetek tych, którzy poszukują innej pracy wynosi ponad 20 proc. Tylko około 3 proc. pracujących na czas nieokreślony podejmuje wysiłek poszukiwania innej pracy wobec około 6 proc. pracujących na czas określony, którzy szukają innej pracy.

Wyniki dotyczące czynników wpływających na intensywność poszukiwania pracy przez osoby pracujące są w odniesieniu do typu kontraktów, płci oraz wieku zgodne z obserwacjami z innych krajów (Pissarides \& Wadsworth, 1994). Bez dokładniejszych analiz wpływu różnych czynników trudno jest znaleźć potwierdzenie innej 
prawidłowości postulowanej w literaturze tzn. większego zaangażowania w poszukiwanie pracy osób pracujących z wyższym wykształceniem. Według danych Diagnozy Społecznej jest raczej odwrotnie - im wyższe wykształcenie, tym większa stabilność zatrudnienia i tym mniejsze bodźce do poszukiwania innej pracy (wykres. 4.9.4). Najwyższy odsetek pracujących poszukujących dodatkowej pracy występuje wśród osób z najniższym wykształceniem i osób młodych, które najczęściej są zatrudniane na najmniej stabilnych kontraktach. Ponadto kobiety szukają innej pracy wyraźnie rzadziej niezależnie od wieku i wykształcenia, z wyjątkiem kobiet w wieku 35-44 lata, które czynią to częściej niż mężczyźni (wykresy 4.9.5, 4.9.6).

Wyniki analiz opartych na danych z Diagnozy Społecznej 2011 wskazują, zatem, że niestabilność kontraktów, w tym kontraktów osób młodych, jest pozytywnie skorelowana z natężeniem poszukiwania pracy. Wśród osób wieku poniżej 25 lat umowy o pracę na czas nieokreślony stanowią zdecydowaną mniejszość (30 proc. wśród mężczyzn i 23 proc. wśród kobiet). Warto jednak zwrócić uwagę, że wraz z wiekiem w większości przypadków następuje stabilizacja warunków zatrudnienia - w grupie wieku 25-34 lata odsetek zatrudnionych na czas określony wynosi 53 proc. wśród mężczyzn i 60 proc. wśród kobiet. Może to świadczyć o tym, że wraz ze zdobywaniem doświadczenia na rynku pracy rośnie stabilność zatrudnienia. Wniosek ten nie jest na tyle silny, aby sformułować konkluzję dotycząca roli mniej stabilnych form zatrudnienia w karierze zawodowej. Diagnoza Społeczna pozwala jednak na analizę dalszych losów na rynku pracy osób pracujących na podstawie różnych typów umów o pracę i bezrobotnych.

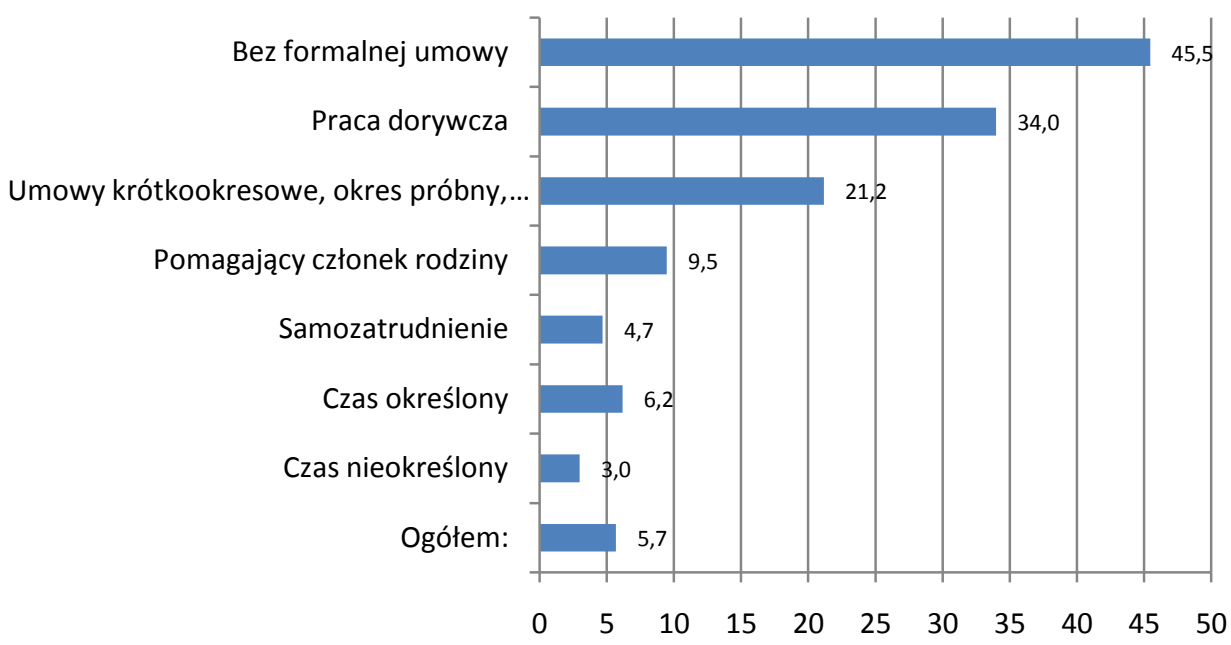

Wykres 4.9.3. Udziat poszukujacych pracy wśród pracujacych wedtug rodzajów pracy

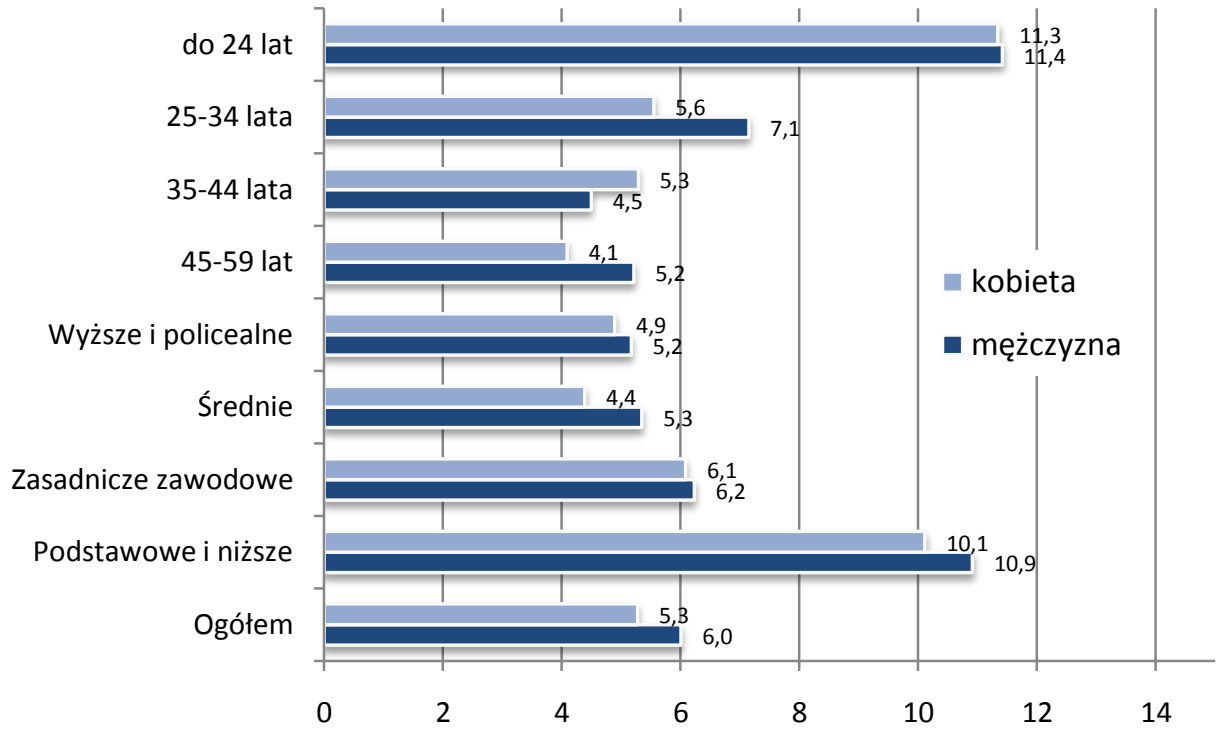

Wykres 4.9.4 Udział poszukujacych pracy wśród pracujacych wedtug płci, wieku i wykształcenia 


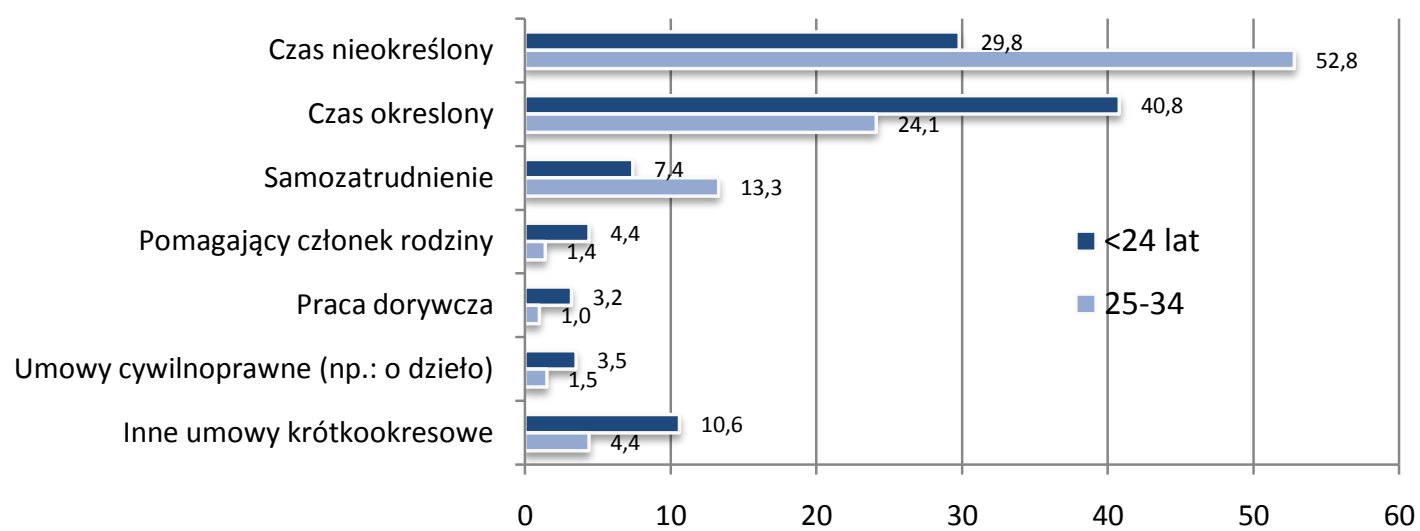

Wykres 4.9.5. Odsetek pracujacych mężczyzn wedtug różnych rodzajów umów

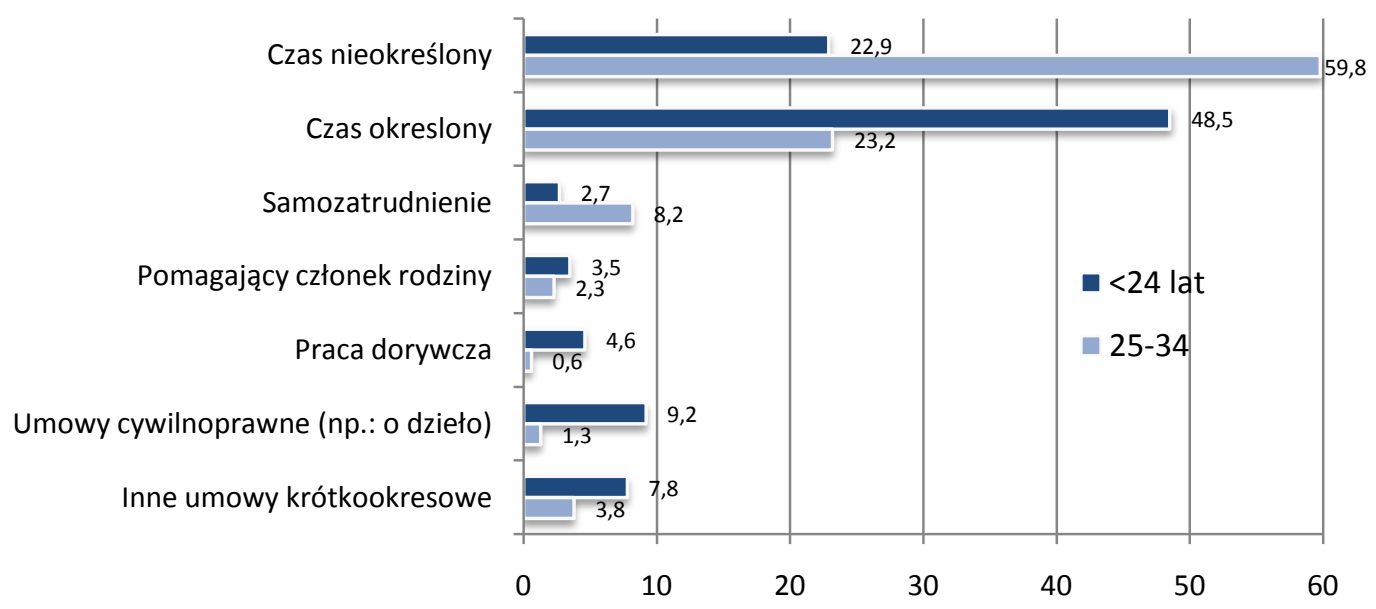

Wykres 4.9.6. Odsetek pracujacych kobiet wedtug różnych rodzajów umów

Analiza dalszych losów w 2011r. osób o różnym statusie na rynku pracy w 2009 r. (tabela 4.9.6) wskazuje, że każda z form czasowego zatrudnienia była związana z wyższą szansą zatrudnienia na czas nieokreślony dwa lata później (około 40 proc. szans) niż w przypadku, gdy osób, która zaczynały, jako bezrobotne (13 proc. szans) lub nieaktywne (6 proc. szans). Z drugiej strony większość umów o pracę oraz samozatrudnienie zmniejszały także ryzyko trafienia do bezrobocia dwa lata później niż poszukiwanie pracy bez podjęcia nawet mniej stabilnego początkowo zatrudnienia. Warto również zwrócić uwagę, że przejście z bezrobocia do umowy na czas określony jest stosunkowo łatwe w porównaniu z umową na czas nieokreślony, co powoduje, że umowy czasowe dają realną szansę na znalezienie pracy osobom, które trudniej znaleźć stabilniejszą formę zatrudnienia. Wyniki te są zgodne z ustaleniami analiz Baranowskiej i Lewandowskiego (2008) o wpływie pracy na czas określony na szanse pozostania w zatrudnieniu, przeprowadzonymi na podstawie danych BAEL z lat 2004-2006. Szanse te są większe wśród pracujących na czas określony niż szanse podjęcia pracy przez osoby bezrobotne lub bierne. Stwierdzili oni wręcz, że 'podejmowanie pracy okresowej przez bezrobotnych wydaje się pełnić rolę 'pomostu' do zatrudnienia' (s.59). Osoby bezrobotne w wieku 15-29 lat, które podjęły pracę na czas określony miały większe szanse podjęcia pracy stałej w porównaniu do osób, które pozostały bezrobotne (s.62).

Jednak pogłębione analizy Baranowskiej (2010) pokazały, że doświadczenie zawodowe pozyskane w trakcie pracy na czas określony nie przekłada się jednoznacznie na wzrost szans podjęcia pracy stałej. Nie stwierdzono jednocześnie, iż zatrudnienie czasowe jest pułapką tzn. im dłuższy okres pracy na czas określony, tym niższe szanse podjęcia pracy stałej i wyższe ryzyko utraty pracy. Skokowy wzrost szans podjęcia stałej pracy po 10-12 miesiącach pracy na czas określony przemawia raczej za występowaniem „efektu screeningu” tzn. umowy na czas na czas określony są proponowane przez pracodawców, by przekonać się o umiejętnościach potencjalnego pracownika i jego przydatności na określonym stanowisku pracy przed zatrudnieniem go na czas nieokreślony.

W świetle tych danych rekomendacje sformułowane w szeroko komentowanym raporcie (Szafraniec, 2011) wydają się warte ponownego przemyślenia. Alternatywą dla nietrwałych form zatrudnienia osób młodych, które w większości pracując poszukują coraz lepszych ofert pracy, jest bowiem pozostawanie na bezrobociu, które zmniejsza szanse na lepszą i stabilniejszą pracę w przyszłości. 
Tabela 4.9.6. Zmiany statusu na rynku pracy w latach 2009 - 2011 wśród osób w wieku 15-34 lat ( proc. osób o określonym statusie w 2009 r.)

\begin{tabular}{lccc}
\hline \multicolumn{1}{c}{ Status w 2009 r. } & $\begin{array}{c}\text { Szansa na zatrudnienie na czas } \\
\text { nieokreślony w 2011 r., według } \\
\text { statusu w 2009 r. }\end{array}$ & $\begin{array}{c}\text { Szansa uzyskania } \\
\text { określonego statusu w } \\
\text { 2011 r. przez osoby } \\
\text { bezrobotne w 2009 r. }\end{array}$ & $\begin{array}{c}\text { Ryzyko bezrobocia w } \\
\text { 2011 r. wedkg statusu w } \\
2009 \text { r. }\end{array}$ \\
\hline Umowa na czas nieokreślony & 75,6 & 13,0 & 3,4 \\
Umowa na czas określony & 40,3 & 22,3 & 7,8 \\
Przedsiębiorca zatrudniający & 12,5 & 0,0 & 0,0 \\
Samozatrudnienie & 7,1 & 3,8 & 2,7 \\
Pomagający członek rodziny & 5,3 & 0,0 & 6,7 \\
Praca dorywcza & 27,3 & 1,4 & 18,2 \\
Inna krótkookresowa umowa o pracę & 28,8 & 2,1 & 13,6 \\
Praca na okres próbny & 53,8 & 0,0 & 15,4 \\
Umowa o dzieło & 30,0 & 3,1 & 10,0 \\
Praca bez formalnej umowy & 10,0 & 4,1 & 36,7 \\
Pozostałe formy pracy & 14,3 & 0,3 & 0,0 \\
Bezrobotny & 13,0 & 31,8 & 31,8 \\
Nieaktywny & 6,1 & 18,2 & 9,8 \\
\hline
\end{tabular}

\subsubsection{Wzrost aktywności zawodowej osób w wieku przedemerytalnym}

W latach 2008-2011 nastapił bezprecedensowy po 1989 roku wzrost odsetka osób aktywnych zawodowo, który dokumentują dane BAEL ${ }^{50}$. Dane Diagnozy Społecznej potwierdzają tę tendencję i wskazują, że głównym źródłem tego wzrostu była zwiększająca się aktywność ekonomiczna osób w wieku 45-59 lat (wykres 4.9.7).

W niniejszej części podejmujemy próbę identyfikacji czynników, które mogły wpłynąć na ten wzrost takich jak zmiany prawne, demograficzne oraz ekonomiczne. Punktem wyjścia dla uzasadnienia wzrastającej aktywności osób w badanej grupie wieku jest ustalenie, czy zmiany struktury wieku wiążące się ze starzeniem się wyżów i niżów demograficznych nie wpłynęły na ten wzrost (wykres 4.9.8). Dane o strukturach wieku ludności pokazują jednak, że od 2003 r. systematycznie maleje w grupie osób w wieku 45-59 lat odsetek osób młodszych (45-49 lat) na korzyść osób w wieku 50-59 lat. Ponadto w latach 2009-2011 osób w wieku bliskim 60 lat było tak wiele, że ich odpływ z rozpatrywanego przedziału wieku związany ze starzeniem przekroczył coraz mniej liczny napływ osób, które w kolejnych latach obchodziły swoje 45 urodziny. Struktura demograficzna osób w wieku przedemerytalnym nie tylko nie wpływała pozytywnie na wzrost aktywności, ale prawdopodobnie hamowała obserwowane wzrosty.

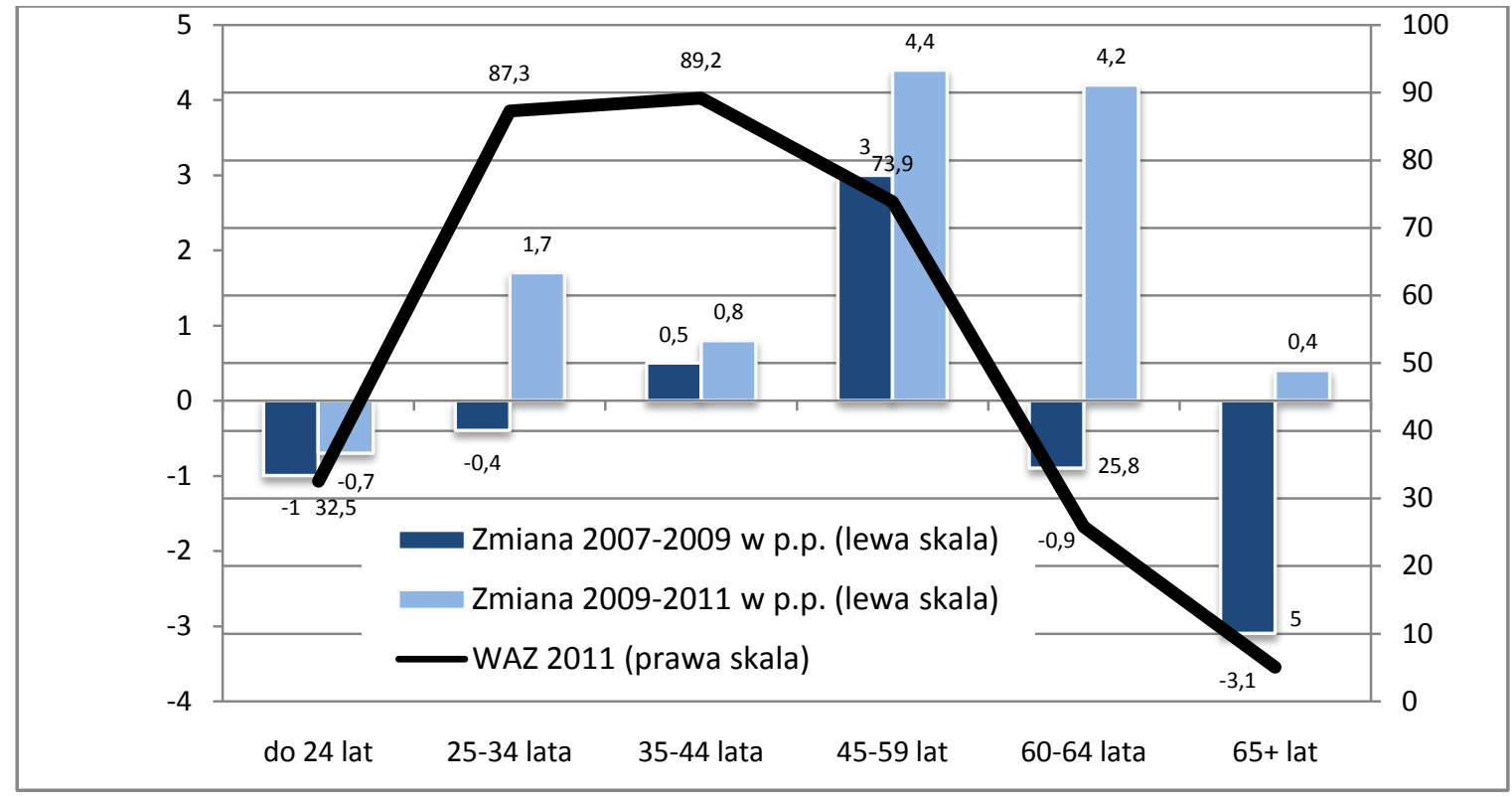

Wykres 4.9.7. Zmiany współczynników aktywności zawodowej według wieku

\footnotetext{
${ }^{50}$ Szerszą analizę na ten temat można znaleźć w pracy (Cichocki et al., 2011, s 11)
} 


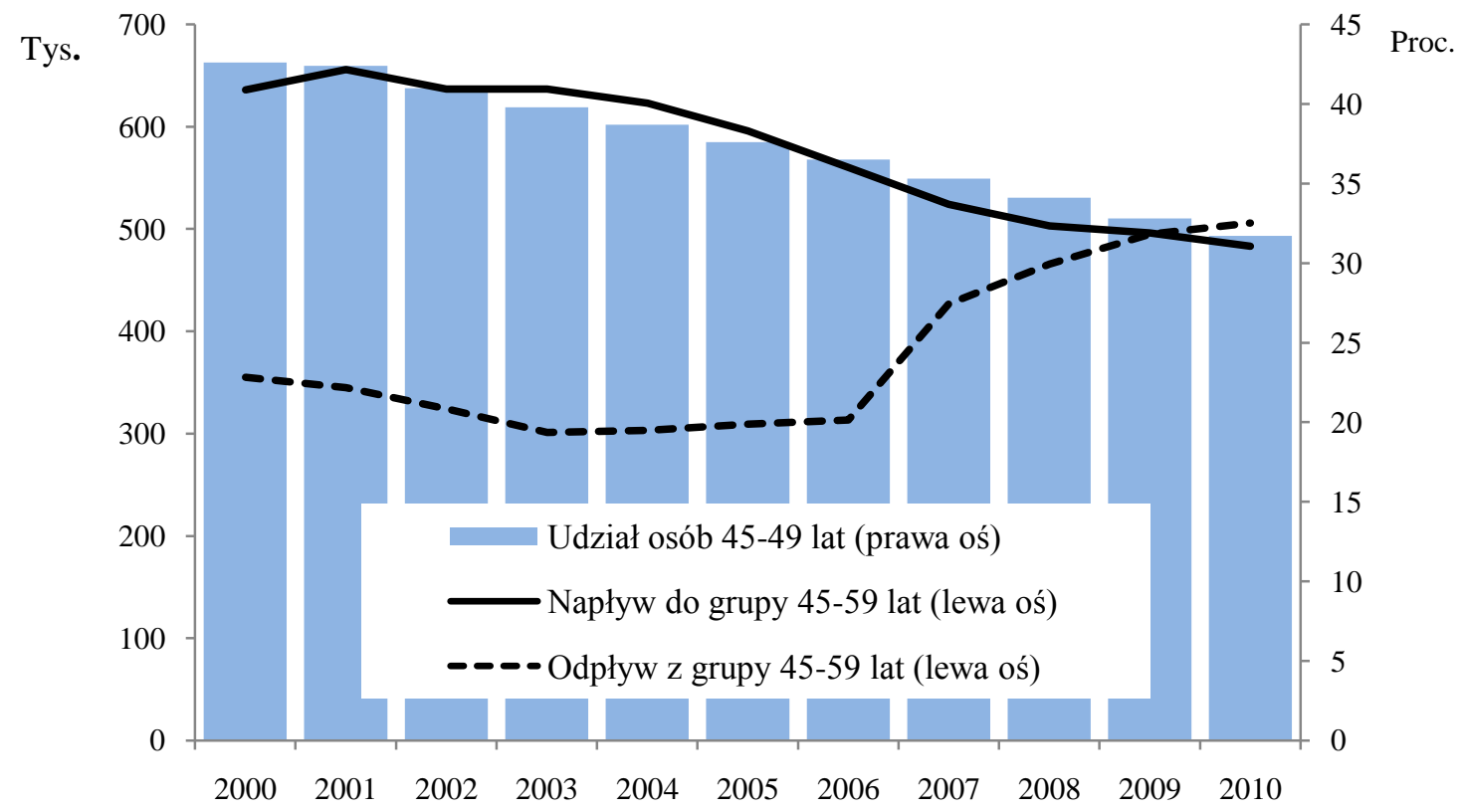

Wykres 4.9.8. Zmiany liczby osób $w$ wieku 45-59 lat-naplywy i odplywy zwiqzane z ,falowaniem” struktury wieku populacji -- oraz procentowy udziat $w$ grupie wieku 45-59 lat osób w wieku 45-49 lat

Poszukując odpowiedzi na pytanie o źródła wzrostu aktywności zawodowej wśród osób w wieku 45-59 lat, warto przyjrzeć się sytuacji osób w tej grupie wieku na rynku pracy oraz źródłom ich utrzymania, jeśli są to osoby bierne zawodowo (tabela 4.9.7). Wzrost aktywności zawodowej w latach 2007-2011 w grupie 45-49 lat wiązał się ze zwiększeniem udziału osób pracujących w tym wieku, natomiast zmiany stopy bezrobocia były stosunkowo niewielkie i odzwierciedlały zmiany sytuacji na rynku pracy. Widać, zatem, że wzrost aktywności osób w rozpatrywanej grupie wieku, w tym osób $\mathrm{w}$ wieku przedemerytalnym, nie wiązał się z zasilaniem przez te osoby szeregów bezrobotnych.

Tabela 4.9.7. Struktura osób w wieku 45-59 lat wedtug aktywności na rynku pracy iźródet utrzymania w latach 2007-2011 (w proc.)

\begin{tabular}{lrrr}
\hline \multicolumn{1}{c}{ Status na rynku pracy i źródła utrzymania } & 2007 & 2009 & 2011 \\
\hline Pracujący & 61,0 & 64,4 & 68,3 \\
Bezrobotni & 5,5 & 5,0 & 5,6 \\
Nieaktywni wg źródeł utrzymania: & & & \\
Dochody z pracy & 0,4 & 0,5 & 0,3 \\
Emerytury & 10,2 & 9,9 & 6,9 \\
Renty inwalidzkie i rodzinne & 12,6 & 10,3 & 9,3 \\
Inne zasiłki i świadczenia (transfery od Państwa) & 4,4 & 3,5 & 3,1 \\
Pozostałe przychody (poza transferami od Państwa) & 0,4 & 0,7 & 0,6 \\
Na utrzymaniu innych członków gospodarstwa & 5,4 & 5,7 & 5,9 \\
Razem & 100,0 & 100,0 & 100,0 \\
\hline
\end{tabular}

Spadek liczby osób nieaktywnych wiązał się także ze zmniejszeniem się udziału osób, których głównym źródłem dochodu były transfery od państwa, w tym odsetka osób deklarujących, że utrzymują się głównie z emerytury. Wskaźnik ten spadł w latach 2009-2011 z blisko 10 proc. do prawie 7 proc., co można uznać przede wszystkim za efekt ograniczenia możliwości wcześniejszego przejścia na emeryturę. Warto także zwrócić uwagę, że do wzrostu aktywności zawodowej systematycznie przyczyniało się ograniczenie możliwości korzystania z rent inwalidzkich. Oddziaływanie tego czynnika można dostrzec już w 2005 r. i wiązać z surowszym orzecznictwem oraz zmianami przepisów dotyczących kontroli stanu zdrowia osób pobierających renty. Systematycznie maleje też udział osób deklarujących, że głównym źródłem utrzymania były pozostałe zasiłki i świadczenia. Z jednej strony mógł być to efekt poprawiającej się do 2009 r. sytuacji na rynku pracy (mniej osób otrzymywało zasiłki dla bezrobotnych), z drugiej strony można zauważyć, że coraz niższa wartość tych świadczeń w porównaniu z płacami (niska waloryzacja) stwarzała bodźce do dodatkowej aktywności na rynku pracy.

Wśród przypuszczalnych czynników wpływających na spadek udziału osób deklarujących rentę jako główne źródło utrzymania można wskazać mniejszą dostępności tego typu świadczeń, coraz lepszy stan zdrowia lub większe możliwości znalezienia pracy pozwalającej osiagnąć dochód przewyższający świadczenie rentowe przez osoby niepełnosprawne. Dane Diagnozy Społecznej upoważniają do stwierdzenia, że wzrost aktywności zawodowej 
w latach 2007-2011 nie był raczej wynikiem poprawy stanu zdrowia (tabela 4.9.8), gdyż odsetek osób posiadających zaświadczenie o niepełnosprawności wśród osób w wieku 45-59 lat nie zmieniał się w znaczący sposób w jednym kierunku. Wśród osób niepełnosprawnych znacznie wzrósł natomiast odsetek pracujących, a spadł odsetek osób nieaktywnych deklarujących rentę, jako główne źródło utrzymania.

Ostatecznie pozytywna zmiana aktywności zawodowej wydaje się z jednej strony być związana $\mathrm{z}$ ograniczeniami dostępu do rent, ale pozostawanie na stosunkowo niewielkim poziomie odsetka osób bezrobotnych wskazuje, że osobom niepełnosprawnym było stosunkowo łatwo znajdować pracę pozwalającą na zastępowanie świadczeń rentowych dochodami $\mathrm{z}$ pracy. $\mathrm{Z}$ drugiej strony relatywnie nieznacznie wzrasta odsetek osób otrzymujących inne świadczenia, co prowadzi do wniosku, że zjawisko poszukiwania innych świadczeń zastępujących świadczenia z tytułu rent nie stanowiło istotnego problemu. Dane wskazują, że prawie nie zmienił się odsetek osób niepełnosprawnych, których głównym źródłem utrzymania jest emerytura, natomiast odsetek osób korzystających z innych świadczeń wzrósł w latach 2007-2011 o 3,7 pp. wobec zmniejszenia się udziału korzystających z rent o 14,8 pp.

Tabela 4.9.8. Aktywność zawodowa i źródta utrzymania osób niepetnosprawnych (w proc.)

\begin{tabular}{lrrr}
\hline & 2007 & 2009 & 2011 \\
\hline Odsetek niepełnosprawnych w populacji w wieku 45-59 lat & 13,4 & 14,5 & 13,4 \\
Udziały wśród niepełnosprawnych 45-59: & & & \\
Pracujący & 18,6 & 24,6 & 28,7 \\
Bezrobotni & 5,4 & 3,3 & 4,5 \\
Bierni zawodowo na emeryturze & 3,9 & 3,8 & 3,7 \\
Bierni zawodowo na rencie & 68,8 & 61,0 & 54,0 \\
Bierni zawodowo utrzymujący się z innych świadczeń & 2,6 & 5,2 & 6,3 \\
Bierni zawodowo utrzymujących się z innych źródeł dochodu & 0,6 & 2,1 & 2,7 \\
\hline
\end{tabular}

Panelowy charakter badania Diagnozy Społecznej pozwala także na prześledzenie procesu przechodzenia na emerytury i renty w rozpatrywanym okresie, odwołując się do indywidualnych zachowań. W kolejnych latach 2007, 2009, $2011 \mathrm{w}$ grupie wieku 45-59 lat wyróżniono następujące stany zdefiniowane przez status na rynku pracy i źródło utrzymania osób biernych zawodowo: pracujący, bezrobotny oraz bierny zawodowo utrzymujący się z następujących źródeł: emerytura, renta inne świadczenie, inny typ dochodu, na utrzymaniu rodziny. Przedmiotem analiz były przejścia pomiędzy zdefiniowanymi stanami w okresach 2007-2009 oraz 2009-2011. Oszacowane prawdopodobieństwa przejścia ze stanów 'pracujący' i ‘bezrobotny' do stanu bierności w związku z otrzymaniem różnych kategorii świadczeń przedstawia tabela 4.9.9, natomiast prawdopodobieństwa przejść ze stanu bierności do stanu aktywności zawodowej zaprezentowano w tabeli 4.9.10.

Wyniki analizy dla napływu do bierności wskazują, że w okresie 2009-2011 nastapił w porównaniu z okresem 2007-2009 bardzo wyraźny spadek prawdopodobieństwa przechodzenia na wcześniejszą emeryturę zarówno wśród pracujących jak i bezrobotnych. Szansa odejścia z rynku pracy z powodu otrzymania renty lub innych świadczeń zmniejszyła się jedynie wśród osób bezrobotnych, co mogło wynikać ze znacznego wzrostu prawdopodobieństwa znajdowania pracy przez osoby w wieku przedemerytalnym (wzrost prawdopodobieństwa znajdowania pracy przez osoby bezrobotne $\mathrm{z}$ około 0,25 do 0,30 ), pomimo gorszych warunków na rynku pracy i widocznego wzrostu ryzyka utraty pracy (prawdopodobieństwo przejścia do bezrobocia przez osoby pracujące wzrosło z 0,025 w okresie 20072009 do 0,032).

Przeprowadzone analizy wskazują, zatem, że ograniczenie dostępu do świadczeń emerytalnych było najistotniejszym czynnikiem zapobiegającym odpływom do nieaktywności. Pozostawanie w aktywności wspierały też relatywnie wysokie i rosnące szanse znalezienia pracy przez analizowane osoby w wieku 45-59 lat.

Tabela 4.9.9. Oszacowania prawdopodobieństw odejść z rynku pracy (z pracy lub z bezrobocia) osób w wieku 45-59 lat do różnych źródel utrzymywania się (kolor szary) lub zmiany statusu na rynku pracy w dwóch okresach 2007-2009 i 2009-2011

\begin{tabular}{llccccccc}
\hline & \multicolumn{7}{c}{ Status końcowy (2 lata później) } \\
\cline { 3 - 9 } \multicolumn{2}{c}{ Status początkowy } & Emerytura & Renta & $\begin{array}{c}\text { Inne } \\
\text { świadczenie }\end{array}$ & $\begin{array}{c}\text { Inny typ } \\
\text { dochodu }\end{array}$ & $\begin{array}{c}\text { Utrzymanie } \\
\text { rodziny }\end{array}$ & Bezrobotny & Pracujący \\
\hline \multirow{2}{*}{ Pracujący } & $2007-2009$ & 0,050 & 0,014 & 0,008 & 0,010 & 0,014 & 0,025 & 0,878 \\
& $2009-2011$ & 0,017 & 0,018 & 0,011 & 0,003 & 0,007 & 0,032 & 0,912 \\
\multirow{2}{*}{ Bezrobotni } & $2007-2009$ & 0,083 & 0,050 & 0,083 & 0,033 & 0,157 & 0,347 & 0,248 \\
& $2009-2011$ & 0,037 & 0,041 & 0,046 & 0,041 & 0,146 & 0,388 & 0,301 \\
\hline
\end{tabular}

*Wiersze sumują się do 100

Tabela 4.9.10, dotycząca napływu do pracy ze stanu bierności zawodowej, ilustruje, że w latach 2009-2011 powroty z emerytury i podejmowanie pracy przez rencistów były rzadsze niż w okresie 2007-2009. Odwołując się do częstościowej interpretacji uzyskanych oszacowań, możemy stwierdzić , że jedynie 6,3 proc osób, które otrzymywały emerytury w 2009 r. deklarowało w 2011r., że pracuje (wobec 7,8 proc przechodzących do 
zatrudnienia w okresie 2007-2009). Jedynie 5,6 proc osób, które pobierały renty w 2009 r. deklarowało w 2011 r., że pracuja, podczas gdy 2 lata wcześniej odsetek ten wynosił 14,2 proc. Można domniemywać, że w „trudniejszych czasach" na rynku pracy osoby, które otrzymały uprawnienia do tego typu świadczeń w satysfakcjonującej wysokości były mniej skłonne do całkowitej lub częściowej rezygnacji z nich, wracając na rynek pracy.

Warto jednak zwrócić uwagę, że nastąpił wzrost szansy przejścia do nieaktywności wśród osób otrzymujących inne typy świadczeń, co mogło wynikać ze stopniowego wygasania praw do niektórych świadczeń przyznawanych wcześniej - np. duża liczba zarejestrowanych osób bezrobotnych pod koniec 2009 r. utraciła w większości prawo do zasiłku dla bezrobotnych pod koniec 2010 r. Można, zatem powiedzieć, że powroty na rynek pracy osób z grupy 45 59 lat są także zależne od koniunktury na rynku pracy. W stosunkowo niewielkim stopniu dotyczą osób, które uzyskały prawa do długookresowych świadczeń takich jak emerytury lub renty, natomiast są relatywnie częstsze wśród osób uzyskujących świadczenia lub zasiłki krótkookresowe.

Tabela 4.9.10. Oszacowania prawdopodobieństw powrotów na rynek pracy (do pracy lub do bezrobocia) osób w wieku 45-59 lat, które wcześniej byly bierne zawodowo i utrzymywaty się z różnego rodzaju świadczeń w dwóch okresach: 2007-2009 oraz 2009-2011.

\begin{tabular}{|c|c|c|c|c|}
\hline \multirow{3}{*}{$\begin{array}{l}\text { Źródło utrzymania w } \\
\text { początkowym okresie }\end{array}$} & \multicolumn{4}{|c|}{ Aktywność na rynku pracy 2 lata później } \\
\hline & \multicolumn{2}{|c|}{ Pracujący } & \multicolumn{2}{|c|}{ Bezrobotni } \\
\hline & $2007-2009$ & 2009-2011 & $2007-2009$ & $2009-2011$ \\
\hline Emerytura & 0,078 & 0,063 & 0,0 & 0,014 \\
\hline Renta & 0,142 & 0,056 & 0,014 & 0,016 \\
\hline Inne świadczenie & 0,071 & 0,097 & 0,024 & 0,062 \\
\hline Inny typ dochodu & 0,250 & 0,320 & 0,0 & 0,280 \\
\hline Utrzymanie rodziny & 0,114 & 0,120 & 0,076 & 0,060 \\
\hline
\end{tabular}

\subsubsection{Godzenie posiadania dzieci i pracy zawodowej - opinie o niektórych rozwiązaniach polityki społecznej}

W Diagnozie Społecznej 2011 ponownie zostało zadane pytanie o rozwiązania, które ułatwiłyby godzenie pracy zawodowej $\mathrm{z}$ obowiązkami rodzinnymi, $\mathrm{w}$ tym zwłaszcza $\mathrm{z}$ obowiązkami rodzicielskimi. Najczęściej wskazywanymi jako najlepsze rozwiązaniami zarówno wśród kobiet jak i mężczyzn były rozwiązania polegające na:

- wydłużaniu urlopu macierzyńskiego - opowiedzieli się za nim, co piąty mężczyzna i co czwarta kobieta,

- lepszej możliwości elastycznego dostosowywania czasu pracy - wskazane przez blisko 26 proc. mężczyzn i 23 proc. kobiet,

- $\quad$ lepszej możliwości opieki poza domem nad dziećmi do 7 roku życia - wymieniło je około 16 proc. respondentów.

Tabela 4.9.11. Preferencje dotyczqce rozwiqzań umożliwiajacych godzenie pracy zawodowej i obowiqzków rodzicielskich

\begin{tabular}{|c|c|c|c|c|}
\hline \multirow[t]{2}{*}{$\begin{array}{c}\text { Rozwiązania umożliwiające godzenie pracy zawodowej i } \\
\text { wychowywania dzieci. }\end{array}$} & \multicolumn{2}{|c|}{$\begin{array}{l}\text { Odsetek wskazujących } \\
\text { rozwiązanie jako } \\
\text { najważniejsze }\end{array}$} & \multicolumn{2}{|c|}{$\begin{array}{l}\text { Średnia punktacja } \\
\quad \text { od } 0 \text { do } 9\end{array}$} \\
\hline & Mężczyźni & Kobiety & Mężczyźni & Kobiety \\
\hline Praca w niepełnym wymiarze & 11,4 & 11,5 & 4,2 & 4,2 \\
\hline Praca w systemie zmianowym & 7,7 & 6,4 & 3,8 & 3,3 \\
\hline Elastyczny czas pracy & 25,6 & 22,9 & 5,7 & 5,7 \\
\hline Możliwość wykonywania części pracy w domu & 9,1 & 7,4 & 4,5 & 4,5 \\
\hline Więcej wolnych dni w tygodniu & 6,9 & 5,9 & 3,8 & 3,6 \\
\hline Dłuższy urlop macierzyński & 20,3 & 26,3 & 5,6 & 6,1 \\
\hline Dłuższy płatny urlop wychowawczy & 9,8 & 11,0 & 5,3 & 5,5 \\
\hline Wyższe zasiłki (wychowawczy, na dzieci) & 12,1 & 13,1 & 4,9 & 5,0 \\
\hline Lepsze możliwości opieki poza domem dzieci do 7 lat & 16,2 & 16,8 & 5,0 & 5,1 \\
\hline Lepsze możliwości opieki poza domem dzieci w wieku 7-12 lat & 7,4 & 7,4 & 3,9 & 3,9 \\
\hline
\end{tabular}

Pomimo wprowadzenia w życie dłuższych urlopów macierzyńskich lista głównych postulowanych rozwiązań nie zmieniła się w stosunku do 2009 r., choć wzrosła częstość wskazań dotyczących elastycznego czasu pracy oraz możliwości opieki poza domem nad dziećmi do 7 roku życia. Nadal nieco częściej najwyższą ocenę dłuższym urlopom macierzyńskim przypisywały kobiety, natomiast mężczyźni - elastyczności pracy. Powyższe wnioski znalazły także odzwierciedlenie w średnich rangach nadanych poszczególnym rozwiązaniom (tabela 4.9.11).

Preferencje dotyczące rozwiązań polityki rodzinnej ułatwiających godzenie pracy zawodowej i obowiązków rodzicielskich są zależne od typu gospodarstwa określonego przez wiek dzieci i ich liczbę (tabela 4.9.12). 
Obecność w gospodarstwie domowym dziecka do 2 lat znacznie podnosiła i tak wysoką nawet wśród osób bez dzieci rangę nadawaną wydłużaniu urlopów macierzyńskich i płatnych urlopów wychowawczych zarówno przez kobiety jak i przez mężczyzn. Ponadto wspomniane rozwiązania były zdecydowanie częściej preferowane przez kobiety w gospodarstwach $\mathrm{z}$ więcej niż dwójką dzieci, co można tłumaczyć dużym obciążeniem czasowym wynikającym z wychowania większej liczby dzieci. Kobiety z gospodarstw domowych z dziećmi zdecydowanie lepiej oceniały też pomoc finansową (zasiłków związanych z posiadaniem dzieci).

Elastyczny czas pracy jest jednym z najbardziej docenianych rozwiązań pozwalających na godzenie aktywności zawodowej z rodzicielstwem wśród osób, w których gospodarstwach domowych nie ma dzieci. Pojawienie się na świecie dziecka zmusza rodziców do organizacji czasu opieki nad dzieckiem, a rozwiązania preferowane przez rodziców posiadających dzieci są nieco inne niż opinie osób z gospodarstw domowych bez dzieci.

Kobiety w gospodarstwach z dziećmi oceniają elastyczny czas pracy niżej, zaś wyższą rangę nadają relatywnie najmniej popularnemu rozwiązaniu, jakim jest możliwość pracy zmianowej. Może to być związane z faktem, iż elastyczny czas pracy w praktyce może powodować większą ilość niepłatnych nadgodzin, podczas gdy praca zmianowa oferuje uelastycznienie czasu pracy z jasnym sprecyzowaniem zakresu obowiązków związanych z pracą. Możliwe, że z podobnych względów gorzej oceniane jest rozwiązanie polegające na wykonywaniu pracy w domu.

Większa ilość wolnych dni w tygodniu jest generalnie jednym z najrzadziej wskazywanych rozwiązań. Jest ono zdecydowanie niżej oceniane przez rodziny $\mathrm{z}$ małymi dziećmi oraz mężczyzn w rodzinach $\mathrm{z}$ dziećmi zapewne dlatego, że w niewielkim stopniu pozwala na rozwiązanie problemu codziennej opieki nad dziećmi, a wiąże się z uzyskiwaniem mniejszych dochodów.

Warto zwrócić uwagę, że o ile opieka nad dziećmi do 7 roku życia uzyskuje stosunkowo wysoką ocenę, to do opieki nad dziećmi w wieku 7-15 lat nie przywiązuje się już takiego znaczenia. Wyjątkiem są osoby posiadające dzieci w wieku 7-15 lat - być może kierują się własnymi doświadczeniami, a mniej stereotypami na temat mniejszej potrzeby opieki nad dziećmi w tym wieku. W przypadku obu typów opieki pozadomowej skłonność do częstszego oceniania jej jako ważną przejawiają mężczyźni w gospodarstwach domowych z dziećmi.

Tabela 4.9.12.Punktacja ważności rozwiazań ułatwiajacych godzenie pracy $i$ wychowania dzieci w gospodarstwach domowych charakteryzujacych się różna liczbq i wiekiem dzieci

\begin{tabular}{|c|c|c|c|c|c|c|c|c|c|c|}
\hline \multirow{2}{*}{$\begin{array}{l}\text { Rozwiązania ułatwiajace } \\
\text { godzenie pracy zawodowej } \\
\text { i wychowywanie dzieci }\end{array}$} & \multicolumn{2}{|c|}{$\begin{array}{c}\text { Osoby bez } \\
\text { dzieci 20-34 lata }\end{array}$} & \multicolumn{2}{|c|}{ Dzieci do 2 lat } & \multicolumn{2}{|c|}{ Dzieci 3-8 lat } & \multicolumn{2}{|c|}{ Dzieci 8-15 lat } & \multicolumn{2}{|c|}{ Wiecej niż 2 dzieci } \\
\hline & $\mathrm{M}$ & $\mathrm{K}$ & M & $\mathrm{K}$ & M & $\mathrm{K}$ & M & $\mathrm{K}$ & M & $\mathrm{K}$ \\
\hline $\begin{array}{l}\text { praca w niepełnym } \\
\text { wymiarze }\end{array}$ & 4,3 & 4,3 & 0,1 & $-0,4$ & 0,1 & 0,2 & $-0,1$ & 0,1 & 0,5 & 0,1 \\
\hline $\begin{array}{l}\text { praca w systemie } \\
\text { zmianowym }\end{array}$ & 3,7 & 3,3 & $-0,2$ & 0,3 & 0,3 & 0,4 & 0,1 & 0,3 & 0,3 & 0,3 \\
\hline elastyczny czas pracy & 5,8 & 5,7 & 0,0 & $-0,5$ & $-0,1$ & $-0,3$ & $-0,1$ & $-0,5$ & $-0,4$ & $-0,8$ \\
\hline $\begin{array}{l}\text { możliwość pracy w domu } \\
\text { więcej wolnych dni w }\end{array}$ & 4,6 & 4,6 & 0,0 & $-0,4$ & $-0,1$ & $-0,5$ & $-0,3$ & $-0,7$ & $-0,3$ & $-0,9$ \\
\hline tygodniu & 3,8 & 3,6 & $-0,8$ & $-0,6$ & $-0,2$ & 0,1 & $-0,3$ & 0,0 & $-0,3$ & 0,0 \\
\hline $\begin{array}{l}\text { dłuższy urlop macierzyński } \\
\text { dłuższy płatny urlop }\end{array}$ & 5,6 & 6,0 & 0,5 & 1,0 & 0,0 & 0,1 & 0,1 & 0,2 & $-0,1$ & 0,5 \\
\hline $\begin{array}{l}\text { wychowawczy } \\
\text { wyższe zasiłki zwiazane z }\end{array}$ & 5,3 & 5,5 & 0,4 & 0,8 & 0,0 & 0,0 & 0,1 & 0,3 & 0,0 & 0,6 \\
\hline $\begin{array}{l}\text { wyższe zasiłk1 związane z } \\
\text { dziećmi }\end{array}$ & 4,8 & 4,9 & 0,5 & 0,6 & 0,3 & 0,3 & 0,3 & 0,4 & 0,1 & 0,9 \\
\hline $\begin{array}{l}\text { lepsza opieka poza domem } \\
\text { do lat } 7 \\
\text { lepsza opieka poza domem }\end{array}$ & 4,8 & 5,1 & 0,3 & 0,2 & 0,1 & $-0,3$ & 0,4 & 0,1 & $-0,1$ & $-0,1$ \\
\hline w wieku 7-12 & 3,7 & 3,9 & $-0,1$ & 0,0 & 0,2 & 0,0 & 0,4 & 0,2 & 0,0 & $-0,2$ \\
\hline
\end{tabular}

Wyniki Diagnozy Społecznej 2011 wskazują, że dla dużej części rodziców mających małe dziecko lub rozważających posiadanie dziecka atrakcyjnym rozwiązaniem jest wydłużenie urlopów macierzyńskiego i wychowawczego, gdyż pozwala to komfortowo opiekować się dzieckiem w pierwszych miesiącach jego życia. Ma to szczególne znaczenie w warunkach relatywnie słabo rozwiniętej i kosztownej infrastruktury opiekuńczej. Naturalną odpowiedzią na pytanie o godzenie aktywności zawodowej z wychowaniem dzieci jest również preferowanie uelastycznienia czasu pracy, choć ze względu na powszechnie występujący w Polsce model opieki nad dzieckiem, wyżej tego typu rozwiązania oceniają mężczyźni. Trzecim, co do ważności rozwiązaniem jest poprawa dostępu do opieki instytucjonalnej nad dzieckiem w wieku do 7 lat.

Istnieją pewne różnice $\mathrm{w}$ deklaracjach osób z gospodarstw domowych z różną liczbą dzieci. Z jednej strony wśród rodziców obciążonych czasowo wychowaniem dzieci (początkujących rodziców oraz wychowujących więcej niż dwoje dzieci) występuje wyraźna preferencja wydłużenia płatnych urlopów oraz zwiększania wysokości zasiłków dla rodziny. Z drugiej strony mężczyźni w gospodarstwach domowych, w których są dzieci w wieku przedszkolnym lub starsze, wyżej niż przeciętnie oceniają rozwiązania polegające na poprawie opieki poza domem. Warto zauważyć, że możliwość pracy w domu była zdecydowanie słabiej niż przeciętna oceniana przez kobiety w gospodarstwach domowych z dziećmi, co może utrudniać jego wprowadzenie w praktyce. Matki nadawały wyższą 
niż przeciętna rangę rozwiązaniom pozwalające na elastyczny czas pracy, ale oddzielony od obowiązków domowych.

\subsubsection{Emigracja zarobkowa - sytuacja emigrantów po powrocie do kraju}

Według danych GUS lata 2009-2011 nie przyniosły znaczącego wzrostu liczby emigrantów zarobkowych. Sytuacja na rynkach pracy w głównych krajach emigracji zarobkowej z Polski ustabilizowała się (Wielka Brytania, Niemcy) lub w dalszym ciągu pogarszała (Irlandia, Hiszpania). Diagnoza Społeczna pozwala na uzyskanie informacji o osobach, które w momencie badania znajdowały się na terytorium Polski, zatem trudno na tej podstawie wnioskować o wielkości obecnej emigracji. Informacje od osób, które wróciły wskazują jednak, że utrata pracy była zdecydowanie rzadziej wskazywana, jako powód powrotu z emigracji zarobkowej (tabela 4.9.13.).

Tabela 4.9.13.Przyczyny powrotów z emigracji zarobkowej (w proc.)

\begin{tabular}{|c|c|c|}
\hline Przyczyny powrotu z emigracji & 2009 & 2011 \\
\hline \multicolumn{3}{|l|}{ Przyczyny ekonomiczne } \\
\hline Zakończenie/utrata pracy & 31,9 & 23,3 \\
\hline Z powodu spadku wysokości dochodów z pracy w porównaniu z zarobkami w kraju & 4,8 & 2,5 \\
\hline Nie mogła znaleźć pracy za granicą & 1,6 & 1,3 \\
\hline \multicolumn{3}{|l|}{ Inne przyczyny } \\
\hline Taki był plan wyjeżdżając zagranicę & 28,5 & 33,5 \\
\hline $\mathrm{Z}$ powodów rodzinnych & 17,3 & 14,6 \\
\hline Z powodów zdrowotnych & 3,2 & 3,6 \\
\hline Czasowo, dla załatwienia spraw w kraju & 3,8 & 9,0 \\
\hline inne powody/ trudno powiedzieć/zakończyła naukę & 7,9 & 11,5 \\
\hline
\end{tabular}

Osoby, które powróciły z emigracji w latach 2009-2011, rzadziej wskazywały powody ekonomiczne powrotów (tabela 4.9.13). Częściej niż w 2009 r. powroty były częścią planów zarówno w przypadku osób, które wróciły na dłużej, jak też osób, które powróciły do kraju przejściowo dla załatwienia różnych spraw. Można zatem ocenić, że dla emigrantów szok, jakim był kryzys w krajach Europy Zachodniej, został już zaabsorbowany i uwzględniony odpowiednio w ich decyzjach.

Procesy migracyjne po wejściu Polski do UE spowodowały, iż doświadczenia z zagraniczną migracją zarobkową stały się częścią biografii dla znaczącej liczby Polaków. Część emigrantów w momencie badania była nadal na emigracji, jednak ciekawym zagadnieniem rozwijanym dalej w niniejszym rozdziale, jest wpływ doświadczeń migracyjnych osób, które wróciły, na ich zachowanie na rynku pracy i w innych dziedzinach.

Wśród osób pozostających w Polsce największy udział osób z doświadczeniami w emigracji zarobkowej obserwowany był wśród osób z wykształceniem zasadniczym zawodowym (niecałe 5,5 proc.) (tabela 4.9.14). Analizy na próbie panelowej wskazują, że w tej grupie wieku ponad 40 proc. osób deklarujących doświadczenia w okresie 2005-2007 wyjeżdżało ponownie pracować za granicę w latach 2007-2011. Nieco większą powtarzalność (około 45 proc.) miały migracje wśród osób z wykształceniem średnim - z tej grupy około 5 proc. emigrowało w latach 2007-2011. Warto zwrócić uwagę, że w okresie 2005-2007 doświadczenia z emigracjami zarobkowymi miało też powyżej 4 proc. osób z wyższym wykształceniem, jednak odsetek ten spadł poniżej 4 proc. w kolejnych latach, a jednym $\mathrm{z}$ powodów było prawdopodobnie relatywnie niewielkie zainteresowanie kolejnymi wyjazdami ze strony osób, które zdobyły doświadczenia w latach 2005-2007.

Stosunkowo niewielka grupa osób, które w 2011 r. miały poniżej 24 lata, była w stanie podjąć w latach 2005 2007 samodzielne wyjazdy i zdobyć doświadczenia migracyjne. W grupie tej jednak 4,8 proc. stanowią osoby, które doświadczyły migracji w latach 2007-2011. Prawie 10 proc. osób mających obecnie 25-34 lata było na emigracji w latach 2005-2007, ale wyjazdy te zwykle nie były kontynuowane w latach 2007-2011 ( powtórzyło je 22 proc. tych osób). Z drugiej strony stosunkowo mniej osób starszych, które wyjechały w latach 2005-2007, zdecydowanie częściej przyjmowało strategię migracji krótkookresowej lub cyrkulacyjnej i osoby te wyjeżdżały ponownie w latach 2007-2011.

Wcześniejsze doświadczenia migracyjne są skorelowanie ze statusem na rynku pracy. Przede wszystkim osoby mające doświadczenia migracyjne są bardziej aktywne na rynku pracy (tabela 4.9.15). Bez szczegółowej analizy trudno jednak mówić tu o związkach przyczynowo-skutkowych, gdyż obserwacja ta może wynikać zarówno z wpływu migracji na postawę osób na rynku pracy jak i selekcję do migracji a potem powrotów osób, które mają predyspozycję do bycia bardziej aktywnym na rynku pracy i gdyby nie wyjechali podnosiliby aktywność osób pozostających w Polsce. 
Tabela 4.9.14.Udziały w populacji w 2011 roku osób z doświadczeniami migracyjnymi w okresie 2005-2007 i w okresie 2008-2011.

\begin{tabular}{|c|c|c|c|}
\hline Cechy emigrantów & $\begin{array}{l}\text { Doświadczenia w } \\
\text { latach 2005-2007 }\end{array}$ & $\begin{array}{l}\text { Doświadczenia w } \\
\text { latach 2007-2011 }\end{array}$ & $\begin{array}{c}\text { Odsetek powtarzających migracje } \\
\text { po okresie } 2005-2007 *\end{array}$ \\
\hline \multicolumn{4}{|l|}{ Wykształcenie } \\
\hline Mężczyźni & 5,8 & 5,5 & 55,2 \\
\hline Kobiety & 2,8 & 2,3 & 30,0 \\
\hline \multicolumn{4}{|l|}{ Wykształcenie } \\
\hline Podstawowe & 2,6 & 2,8 & 0,0 \\
\hline Zasadnicze zawodowe & 5,3 & 5,4 & 41,2 \\
\hline Średnie & 4,1 & 4,9 & 45,5 \\
\hline Wyższe & 4,2 & 3,9 & 22,2 \\
\hline \multicolumn{4}{|l|}{ Wiek } \\
\hline Poniżej 24 & 0,9 & 4,8 & 0,0 \\
\hline $25-34$ & 9,9 & 6,7 & 21,9 \\
\hline $35-44$ & 6,5 & 6,1 & 37,5 \\
\hline $45-59$ & 4,1 & 3,3 & 45,5 \\
\hline $60-65$ & 1,0 & 0,4 & 0,0 \\
\hline \multicolumn{4}{|l|}{ Miejscowość zamieszkania } \\
\hline miasta 500 tys. i więcej & 3,9 & 3,2 & 11,1 \\
\hline miasta200-500 tys. & 5,7 & 4,9 & 92,3 \\
\hline miasta100-200 tys. & 4,5 & 3,7 & 50,0 \\
\hline miasta $20-100$ tys. & 4,8 & 4,0 & 52,6 \\
\hline miasta poniżej 20 tys. & 5,6 & 5,6 & 26,1 \\
\hline wieś & 5,8 & 5,2 & 23,8 \\
\hline
\end{tabular}

Tabela 4.9.15.Doświadczenia migracyjne osób w wieku produkcyjnym a ich status na rynku pracy w 2009 i 2011 r.

\begin{tabular}{lccc}
\hline \multirow{2}{*}{ Status na rynku pracy w 2011 roku } & $\begin{array}{c}\text { Odsetek osób z doświadczeniami w ciągu } \\
\text { ostatnich 4 lat }\end{array}$ & $\begin{array}{c}\text { Odsetek wśród osób w } \\
\text { wieku produkcyjnym } \\
\text { ogółem w 2011 roku }\end{array}$ \\
\cline { 2 - 3 } & 2009 & 2011 & \\
\hline Pracujący & \multicolumn{2}{c}{ Mężczyźni } \\
w tym na własny rachunek & 75,9 & 80,1 & 71,0 \\
Bezrobotni & 7,9 & 9,3 & 7,5 \\
Nieaktywni zawodowo & 16,2 & 14,8 & 6,8 \\
\hline & 7,9 & 5,1 & 22,2 \\
\hline Pracujące & \multicolumn{3}{c}{ Kobiety } \\
w tym na własny rachunek & 56,3 & 54,4 & 57,6 \\
Bezrobotne & 4,2 & 2,7 & 3,3 \\
Nieaktywne zawodowo & 16,9 & 22,8 & 7,1 \\
\hline & 26,8 & 22,8 & 37,7 \\
\hline
\end{tabular}

Zestawienie danych o osobach mających doświadczenia migracyjne w ciągu 4 lat przed badaniem w 2009 r. i w 2011 r. prowadzi do wniosku, że w obu badaniach widać wyraźne różnice pomiędzy kobietami i mężczyznami uczestniczących $\mathrm{w}$ wyjazdach $\mathrm{w}$ ostatnich czterech latach. Wśród mężczyzn wcześniejsze doświadczenia $\mathrm{z}$ emigracją wiązały się nie tylko z wyższym niż przeciętne bezrobociem, ale i z większymi szansami zatrudnienia oraz większym niż przeciętny odsetkiem prowadzących własną działalność zawodową. W przypadku kobiet odsetek pracujących wśród kobiet $\mathrm{z}$ doświadczeniami migracyjnymi był nawet nieco niższy od obserwowanego ogółem, mniejsze było też ich zaangażowanie we własną działalność gospodarczą, natomiast wyższa aktywność zawodowa wynikała z trzykrotnie większego niż w całej populacji kobiet odsetka bezrobotnych.

W stosunku do 2009 r. wyraźnie pogłębiły się różnice pomiędzy pozycją na rynku pracy mężczyzn i kobiet mających doświadczenia migracyjne. Pomimo wzrostu bezrobocia w Polsce w okresie 2009 -2011 odsetek byłych emigrantów na bezrobociu wśród mężczyzn zmniejszył się. Wśród kobiet, które pracowały na emigracji, odsetek ten natomiast zdecydowanie wzrósł.

Od 2009 r. sytuacja na rynkach pracy w większości krajów UE ustabilizowała się, a kraje o relatywnie niskim bezrobociu i rosnącym popycie na pracę zniosły ostatnie bariery dla pracowników z Polski. Pomimo to odsetek osób deklarujących w momencie badania chęć wyjazdu w ciagu najbliższych 2 lat wynosił 8,2 i niewiele różnił się od poziomu 7,6 proc. obserwowanego dwa lata wcześniej. W porównaniu do danych z 2007 r., kiedy 13,5 proc. respondentów deklarowało chęć emigracji, deklaracje chęci wyjazdu są o wiele rzadsze, co może wskazywać, że gorączka emigracyjnej z okresu po wejściu Polski do Unii Europejskiej już się nie powtórzy. Może na to wpływać spowolnienie gospodarcze, które w Europie Zachodniej nastąiło już w 2008 r. 
Struktura osób chcących wyjechać zmieniła się nieznacznie (tabela 4.9.16). W 2011 r. podobnie jak w 2009 r. zamiar wyjazdu zarobkowego poza Polskę w ciagu następnych dwóch lat deklaruje około jedna piąta osób bezrobotnych, około 8 proc. osób nieaktywnych zawodowo i około 7 proc. osób pracujących. Główną różnicą w stosunku do wyników z 2009 r. jest wzrost chęci wyjazdu przez osoby bezrobotne z wykształceniem zasadniczym zawodowym, czyli tych osób, którym praca za granicą może przynieść relatywnie największy wzrost potencjalnego wynagrodzenia.

Tabela 4.9.16. Osoby planujace emigrację zarobkowq wedtug statusu na rynku pracy oraz wykształcenia w 2007, 2009 i $2011 \mathrm{r}$

\begin{tabular}{lccc}
\hline \multirow{2}{*}{ Wykształcenie } & Pracujący & Bezrobotny & Bierny \\
\cline { 2 - 3 } & Deklaracje wyjazdu w 2011 roku & 6,7 \\
Wyższe i policealne & 5,1 & 16,3 & 10,0 \\
Średnie & 7,4 & 23,5 & 9,0 \\
Zasadnicze zawodowe/gimnazjum & 8,1 & 22,1 & 3,1 \\
Podstawowe i niższe & 5,9 & 14,4 & 8,3 \\
Ogółem & 6,8 & 20,5 & 7,0 \\
\hline & Deklaracje wyjazdu w 2009 roku & 9,2 \\
\hline Wyższe i policealne & 4,2 & 17,4 & 8,8 \\
Średnie & 6,5 & 24,2 & 3,0 \\
Zasadnicze zawodowe/gimnazjum & 7,7 & 17,8 & 7,9 \\
Podstawowe i niższe & 6,8 & 15,5 & 14,0 \\
Ogółem & 6,2 & 19,5 & 18,2 \\
& Deklaracje wyjazdu w 2007 roku & 15,5 \\
\hline Wyższe i policealne & 8,3 & 19,3 & 3,8 \\
Średnie & 13,0 & 31,9 & 14,5 \\
Zasadnicze zawodowe/gimnazjum & 14,3 & 23,0 & 21,5 \\
Podstawowe i niższe & 8,1 & 25,4 & \\
Ogółem & 11,7 & & \\
\hline
\end{tabular}

Większość deklarujących wyjazd za granicę (74,5 proc.) nie miała doświadczeń migracyjnych w ciągu ostatnich czterech lat. Jednak to właśnie wśród osób, które pracowały za granicą w latach 2007-2011, około 46 proc. planowało kolejny wyjazd, podczas gdy wśród pozostałych osób było to około $6 \%$ proc. Wyniki te potwierdzają wcześniejsze spostrzeżenie, że doświadczenia migracyjne wpływają na postrzeganie emigracji jako potencjalnej opcji wyboru i zwiększają częstość kolejnych wyjazdów.

W stosunku do 2007r. i 2009 r. istotnie mniejszy był udział osób deklarujących wyjazdy krótkookresowe poniżej 1 roku oraz wśród mężczyzn także poniżej 2 lat (tabela 4.9.17). Wzrósł natomiast udział osób deklarujących, że wyjechałby na stałe. Wydaje się, że część mężczyzn deklarujących do tej pory migracje krótkookresowe mogła także w ostatnim badaniu wybrać odpowiedź „to zależy”. Wraz z ogólnym wzrostem skłonności do migracji na stałe może to oznaczać, że po okresie, w którym część osób doceniała zalety życia w zawieszeniu pomiędzy Polską a docelowym krajem migracji, obecnie więcej osób zaczyna traktować emigrację, jako decyzję długookresową powiązaną z innymi zdarzeniami w swej biografii, takimi jak zakładanie rodziny, funkcjonowanie w kręgu najbliższych, osiedlanie się itd.

Tabela 4.9.17. Planowany czas pozostawania za granicq osób deklarujacych chęć wyjazdu w latach 2007, 2009 $i$ 2011

\begin{tabular}{|c|c|c|c|c|c|c|}
\hline \multirow{3}{*}{$\begin{array}{c}\text { Planowany czas pobytu } \\
\text { za granicą }\end{array}$} & \multicolumn{6}{|c|}{ Odsetek odpowiedzi wśród osób deklarujących migrację zarobkową w ciągu następnych 2 lat } \\
\hline & \multicolumn{3}{|c|}{ Mężczyźni } & \multicolumn{3}{|c|}{ Kobiety } \\
\hline & 2007 & 2009 & 2011 & 2007 & 2009 & 2011 \\
\hline Poniżej 1 roku & 33,4 & 35,1 & 27,4 & 37,1 & 42,9 & 38,3 \\
\hline 1-2 lata & 10,8 & 11,7 & 6,9 & 7,7 & 8,4 & 8,4 \\
\hline Więcej niż 2 lata & 6,6 & 6,2 & 6,8 & 7,4 & 3,6 & 5,8 \\
\hline Na zawsze & 6,0 & 6,7 & 9,4 & 5,3 & 3,7 & 5,0 \\
\hline To zależy & 43,1 & 40,4 & 49,5 & 42,5 & 41,3 & 42,5 \\
\hline
\end{tabular}

Stan gospodarki poszczególnych krajów docelowych ma duże znacznie dla deklaracji wyjazdowych. W $2011 \mathrm{r}$. osoby, które wskazały kierunek swojego możliwego wyjazdu, najczęściej deklarowały wyjazd do Niemiec (wykres 4.9.9. Otwarcie rynków pracy w Niemczech i Austrii mogło w pewnym stopniu wpłynąc na dodatkowe uatrakcyjnienie tego kierunku wyjazdów, ale analizy ekonometryczne (Strzelecki \& Wyszyński, 2011) wskazują, że głównym czynnikiem oddziaływującym na emigrację z Polski do krajów UE w horyzoncie kilku lat są różnice w stopach bezrobocia pomiędzy krajami, a wzmożone migracje związane z efektami „nowości” otwierających się rynków pracy kolejnych państw Europy Zachodniej były na ogół niewielkie po 2005 r. 


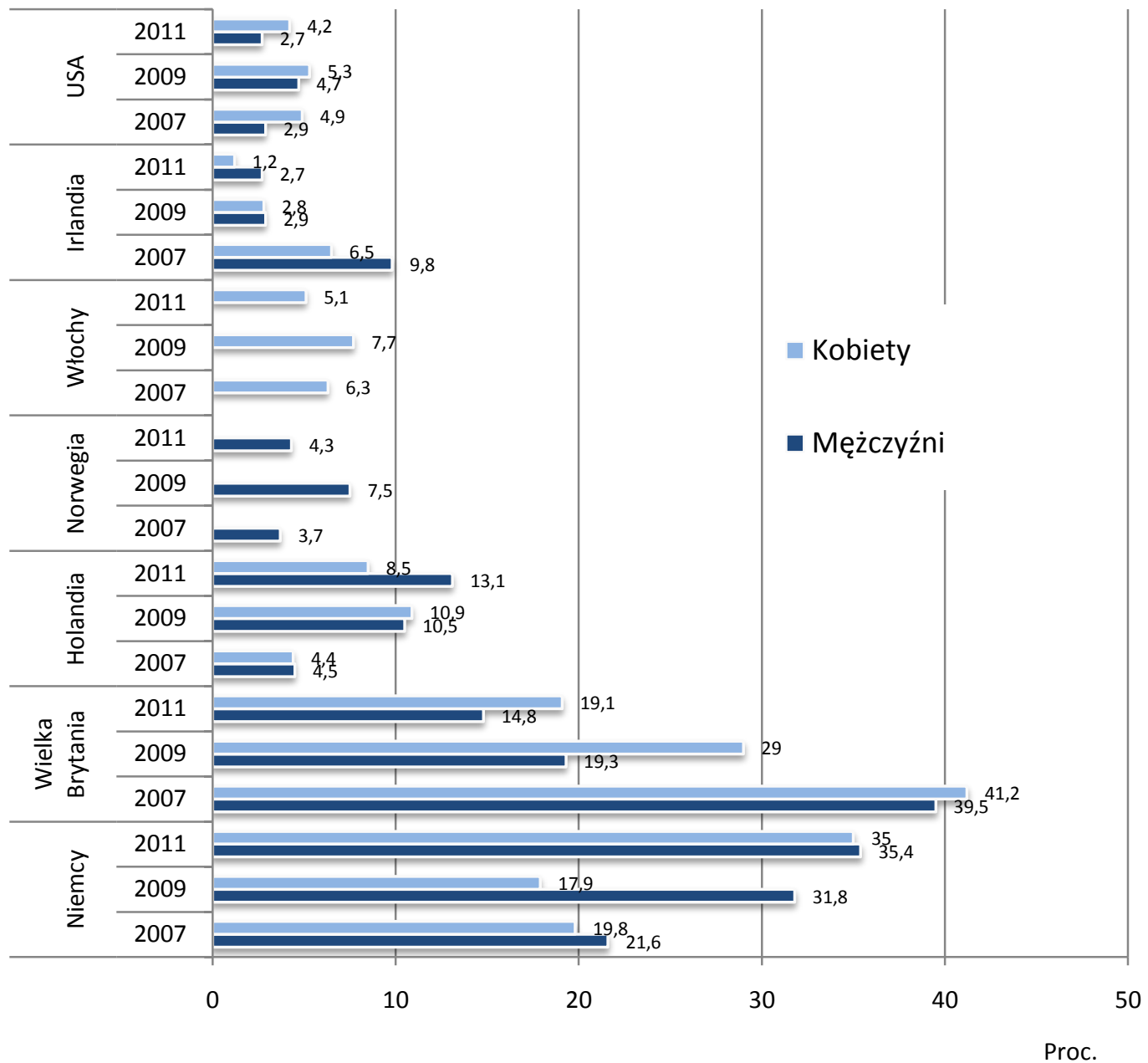

UWAGI: nie ma danych dotyczących Norwegii dla kobiet i Włoch dla mężczyzn, ponieważ kierunki te nie należały do atrakcyjnych dla danej plci

Wykres 4.9.9. Najpopularniejsze dla kobiet i mężczyzn kierunki zamierzonych emigracji zarobkowych w 2007, 2009 i $2011 \mathrm{r}$.

Niepewna sytuacja na rynku pracy w Wielkiej Brytanii oraz katastrofalna sytuacja gospodarcza Irlandii spowodowały, że wyjazd do tych krajów deklaruje coraz mniej osób. Wśród mężczyzn rośnie natomiast popularność wyjazdów do Holandii. Po wzroście w 2009r. zmniejszył się natomiast odsetek deklarujących wyjazdy do krajów, które w 2009 r. postrzegane były jako bezpieczne alternatywy dla ogarniętych kryzysem typowych krajów docelowych emigracji. Dla deklarujących wyjazd mężczyzn takim krajem była Norwegia, natomiast dla kobiet Włochy. Na stabilnym kilkuprocentowym poziomie (wyższym wśród kobiet) utrzymuje się odsetek osób chcących wyemigrować do USA.

Analizy dotyczące deklaracji wyjazdowych warto zakończyć podsumowaniem, iż spadek deklaracji wyjazdu w 2009 r. wiązał się z poprawą ich wiarygodności. Wśród respondentów deklarujących chęć wyjazdu za granicę, o których uzyskano ponownie informację w 2011 r., około 19,5 proc. zrealizowało te plany i wróciło, natomiast realizacja deklaracji z $2007 \mathrm{r}$. była w badaniu z 2009 r. na poziomie 14,4 proc., a kolejne 2,5 proc. przebywało nadal za granicą w momencie wywiadu ${ }^{51}$.

\footnotetext{
${ }^{51}$ Ze względu na brak uwzględnienia informacji o gospodarstwach domowych, które w całości wyemigrowały odsetek ten jest prawdopodobnie wyższy.
} 


\subsubsection{Doskonalenie zawodowe a status na rynku pracy}

Izabela Grabowska, Irena E. Kotowska

\subsubsection{Zasięg dokształcania zawodowego}

Na podstawie danych z wcześniejszych edycji Diagnozy Społecznej możliwa jest analiza aktywności związanej z podnoszeniem przez respondentów swoich kwalifikacji zawodowych czy innych umiejętności w okresie 2005-2007, 2007-2009 oraz 2009-2011 52 .

Zaledwie około 11 proc. osób w wieku 25 lat i więcej uczestniczyło w latach 2009-2001 w jakiejkolwiek aktywności związanej z podnoszeniem swoich kwalifikacji zawodowych czy innych umiejętności, a więc nieco rzadziej niż wskazywały na to wyniki z lat 2005-2007 i 2007-2009. Analiza struktury osób, które w Diagnozie Społecznej 2007, 2009, 2011 zadeklarowały taką aktywność, wskazuje na wysoką i utrzymującą się selektywność procesu dokształcania się głównie ze względu na wiek, poziom wykształcenia oraz miejsce zamieszkania (tabela 4.9.24.).

Tabela 4.9.24. Struktura osób $w$ wieku 25 lat $i$ więcej uczestniczqcych w jakiejkolwiek aktywności zwiqzanej z podnoszeniem swoich kwalifikacji zawodowych czy innych umiejętności w latach 2005-2007, 2007-2009, 2009 2011 według płci, wykształcenia, miejsca zamieszkania i wieku (w proc.)

\begin{tabular}{|c|c|c|c|}
\hline \multirow[t]{2}{*}{ Cechy demograficzno-społeczne } & \multicolumn{3}{|c|}{$\begin{array}{l}\text { Odsetek osób w wieku } 25 \text { lat i więcej uczestniczących w podnoszeniu } \\
\text { swoich kwalifikacji zawodowych czy innych umiejętności w latach }\end{array}$} \\
\hline & $2005-2007$ & $2007-2009$ & $2009-2011$ \\
\hline Ogółem & 11,7 & 11,9 & 10,7 \\
\hline Kobiety & 56,8 & 51,9 & 54,0 \\
\hline Mężczyźni & 43,2 & 48,1 & 46,0 \\
\hline Wyższe i policealne & 57,5 & 57,4 & 62,2 \\
\hline Średnie & 28,5 & 29,0 & 24,7 \\
\hline Zasadnicze zawodowe & 11,8 & 11,9 & 10,6 \\
\hline Podstawowe i poniżej & 2,2 & 1,7 & 2,5 \\
\hline Miasta powyżej 500 tys. & 23,6 & 24,1 & 25,2 \\
\hline Miasta od 200 do 500 tys. & 17,0 & 17,2 & 17,2 \\
\hline Miasta od 100 do 200 tys. & 8,4 & 8,0 & 8,0 \\
\hline Miasta od 20 do 100 tys. & 19,6 & 19,2 & 20,0 \\
\hline Miasta poniżej 20 tys. & 11,8 & 10,4 & 10,6 \\
\hline Wieś & 19,6 & 21,0 & 19,0 \\
\hline 25-29 lat & 25,8 & 27,3 & 25,7 \\
\hline 30-34 lata & 20,9 & 18,7 & 19,9 \\
\hline 35-39 lat & 14,3 & 16,4 & 16,2 \\
\hline 40-44 lata & 12,8 & 12,0 & 12,6 \\
\hline 45-49 lat & 10,4 & 10,6 & 9,2 \\
\hline 50-54 lata & 9,3 & 8,4 & 8,0 \\
\hline 55 lat $\mathrm{i}$ więcej & 6,4 & 6,6 & 8,5 \\
\hline
\end{tabular}

Wśród osób podnoszących swe umiejętności w latach 2009-2011 większość wciąż stanowiły kobiety, około 54 proc. (około 52 proc. w latach 2007-2009 r. i 57 proc. w 2005-2007), a ich udział nieznacznie wzrósł w porównaniu z poprzednią rundą badania. Około 62 proc. osób dokształcających się w ciągu ostatnich dwóch lat miało wykształcenie wyższe lub policealne w porównaniu z około 57 proc. w latach 2005-2007 i 2007-2009, odsetek osób z wykształceniem średnim podnoszących swoje umiejętności wyniósł blisko 25 proc. wobec około 29 proc. W dwóch poprzednich rundach badania, a posiadających wykształcenie gimnazjalne lub zasadnicze zawodowe było zaledwie 11 proc. (około 12 proc. w dwóch poprzednich rundach). Najmniej osób podnoszących swoje kwalifikacje w latach 2009-2011 legitymowało się wykształceniem co najwyżej podstawowym - 2,5 proc. (2,2 proc. w latach 2005-2007 i 1,7 proc. w latach 2007-2009).

Struktura dokształcających się według klasy miejscowości zamieszkania także nie uległa większym zmianom w latach 2009-2011 w porównaniu do dwóch poprzednich rund. Jedynie co piąta osoba, która podnosiła swoje kwalifikacje zamieszkiwała na wsi. Wśród dokształcających się mieszkańców miast wciąż nieco ponad połowę stanowią osoby pochodzące z miast powyżej 100 tys. mieszkańców, około 20 proc. z miast od 20 do 100 tys. mieszkańców, a około 11 proc. z miast poniżej 20 tys. mieszkańców (13-15 proc. dla lat 2005-2007 i 2007-2009). Nie zaobserwowano także istotnych zmian w strukturze dokształcających się według wieku w trzech

\footnotetext{
${ }^{52}$ Wyników otrzymanych w Diagnozie Społecznej 2007, 2009 i 2011 nie można porównywać bezpośrednio z wynikami badania BAEL dotyczącymi aktywności edukacyjnej dorosłych. W Diagnozie Społecznej pytano o aktywność edukacyjną w ciagu ostatnich dwóch lat, natomiast w BAEL pomiar dotyczy ostatnich 4 tygodni przed badaniem. Ponadto pytanie o aktywność związaną z podnoszeniem kwalifikacji zawodowych czy innych umiejętności w Diagnozie obejmuje zarówno aktywność w systemie szkolnym jak i pozaszkolnym, natomiast w przypadku BAEL obie kategorie rozpatrywane są odrębnie. Ponadto w niniejszej części opracowania analiza aktywności w zakresie doskonalenia zawodowego obejmuje osoby w wieku 25 lat i więcej.
} 
rozpatrywanych okresach. Osoby dokształcające się to wciąż głównie osoby młode - około $46-47$ proc. jest w wieku 25-34 lata. Osoby w wieku 35-44 lat stanowią około 28-29 proc. wśród dokształcających się, a osoby będące w wieku 45-54 lata - około 17 proc. w latach 2009-2011 oraz 19-21 proc. w latach 2005-2007 i 2007-2009. Udział osób w wieku 55 lat więcej wśród osób podnoszących swoje kwalifikacje wynosi zaledwie około 7-8,5 proc.

Podsumowując, typowa osoba uczestnicząca w jakiejkolwiek aktywności związanej z podnoszeniem swoich kwalifikacji zawodowych czy innych umiejętności to wciąż osoba z wyższym wykształceniem, w wieku 25-34 lata, mieszkająca w dużym mieście, częściej kobieta niż mężczyzna.

Powyższe dane odzwierciedlają strukturę osób podnoszących swoje kwalifikacje w latach 2005-2007, 20072009 oraz 2009-2011, która zależy nie tylko od aktywności edukacyjnej określonych grup ludności, ale także od struktury respondentów według rozpatrywanych cech53. Odniesienie ich do odpowiednich subpopulacji pozwala na ocenę natężenia procesu.

Tabela 4.9.25. Uczestnictwo osób $w$ wieku powyżej 25 lat w jakiejkolwiek aktywności zwiqzanej z podnoszeniem kwalifikacji zawodowych lub innych umiejętności w ciqgu ostatnich 2 lat wedtug miejsca zamieszkania oraz płci w latach 2005-2007, 2007-2009, 2009-2011 (w proc. osób danej kategorii)

\begin{tabular}{|c|c|c|c|c|c|c|c|}
\hline Wyszczególnienie & $\begin{array}{c}\text { Miasta } \\
>500 \text { tys. }\end{array}$ & $\begin{array}{l}\text { Miasta 200- } \\
500 \text { tys. }\end{array}$ & $\begin{array}{l}\text { Miasta } 100 \\
-200 \text { tys. }\end{array}$ & $\begin{array}{l}\text { Miasta } 20 \text { - } \\
100 \text { tys. }\end{array}$ & $\begin{array}{c}\text { Miasta }<20 \\
\text { tys. }\end{array}$ & Wieś & Ogółem \\
\hline \multicolumn{8}{|c|}{$2005-2007$} \\
\hline Ogółem & 24,4 & 17,0 & 11,8 & 11,0 & 10,6 & 6,2 & 11,7 \\
\hline Kobiety & 24,7 & 18,0 & 11,3 & 11,5 & 11,0 & 6,6 & 11,9 \\
\hline Mężczyźni & \multicolumn{6}{|c|}{ 2007-2009 } & 11,2 \\
\hline Ogółem & 22,8 & 18,2 & 13,5 & 11,9 & 9,3 & 6,8 & 11,9 \\
\hline Kobiety & 23,5 & 18,6 & 12,1 & 11,3 & 8,7 & 6,0 & 11,6 \\
\hline Mężczyźni & \multicolumn{6}{|c|}{ 2009-2011 } & 12,2 \\
\hline Ogółem & 20,9 & 18,3 & 11,2 & 11,0 & 8,8 & 5,5 & 10,7 \\
\hline Kobiety & 20,7 & 18,0 & 10,4 & 11,3 & 8,6 & 5,2 & 10,8 \\
\hline Mężczyźni & 21,2 & 17,5 & 12,0 & 10,6 & 9,1 & 5,8 & 10,6 \\
\hline
\end{tabular}

Dane zamieszczone w tabeli 4.9.25 potwierdzają selektywność procesu doskonalenia umiejętności zawodowych w odniesieniu do miejsca zamieszkania, niekorzystną szczególnie dla mieszkańców wsi. Wraz ze wzrostem wielkości miejscowości zamieszkania aktywność związana $\mathrm{z}$ doskonaleniem zawodowym jest częściej podejmowana - udział aktywnych osób zmienia się od około 10-15 proc. dla miast liczących poniżej 200 tys. mieszkańców do 22-25 proc. dla miast liczących powyżej 500 tys. mieszkańców dla trzech analizowanych okresów. Jedynie około 5-7 proc. mieszkańców wsi brało udział w podnoszeniu swych kwalifikacji.

W latach 2009-2011 zanotowano niewielki spadek aktywności związanej z podnoszeniem własnych kwalifikacji czy umiejętności zawodowych dla wszystkich typów klasy miejscowości zamieszkania, zarówno dla kobiet jak i mężczyzn. Obserwowany w latach 2007-2009 wzrost aktywności edukacyjnej mężczyzn zamieszkujących przede wszystkim wsie, a także miasta małe i średnie nie utrzymał się, ale mężczyźni nadal czynili to nieznacznie częściej niż kobiety z analogicznych typów miejscowości.

Uczestnictwo w doskonaleniu zawodowym według wieku w latach 2009-2011 nie uległo istotnej zmianie w porównaniu z latami 2005-2007 i 2007-2009.

Podobnie nie zmieniła się aktywność związana z podnoszeniem kwalifikacji według poziomu wykształcenia (tabela 4.9.26.). Osoby lepiej wykształcone chętniej brały udział w różnych formach doskonalenia umiejętności zawodowych. Najczęściej dokształcały się osoby z wyższym wykształceniem (około 27 proc.), równie często kobiety i mężczyźni, choć czynili to nieco rzadziej niż w okresie 2005-2007 i 2007-2009 (około 30 proc.). Wyraźnie rzadziej podnosiły swe kwalifikacje osoby z wykształceniem średnim (9 proc. wobec 11-12 proc. w latach $2005-$ 2007 i 2007-2009), przy czym nadal nieco bardziej aktywni byli mężczyzn o tym poziomie wykształcenia niż kobiety. Natomiast osoby o wykształceniu zasadniczym zawodowym stale podejmują tego typu aktywność ponad dwa razy rzadziej niż osoby z wykształceniem średnim (około 4-5 proc.). Co prawda kobiety z wykształceniem zasadniczym zawodowym są mniej aktywne niż mężczyźni w doskonaleniu swych umiejętności, ale ta różnica zmniejszyła się. Osoby z wykształceniem co najwyżej podstawowym niezmiennie nie uczestniczą w tym procesie.

Wyniki te potwierdzają wysoko selektywny charakter procesu dokształcania, podobnie zresztą jak rezultaty badania Kształcenie Dorosłych (Główny Urząd Statystyczny, Warszawa 2009)54. Pomimo nieco odmiennej definicji uczestnictwa w różnego typu usługach edukacyjnych w obu badaniach, uniemożliwiającej bezpośrednie porównanie wyników liczbowych, konkluzje sformułowane na ich podstawie są analogiczne. Dokształcają się głównie ludzie młodzi, dobrze wykształceni i mieszkańcy większych miast. Około 40 proc. osób dokształcających się w latach 2007-2009 podejmowała aktywność edukacyjną także w latach 2009-2011, a 44 proc. dokształcających

\footnotetext{
${ }^{53} \mathrm{~Np}$. w 2007 mieszkańcy miast największych stanowili 11 proc. ogółu respondentów w wieku 25 lat i więcej, a mieszkańcy miast najmniejszych oraz wsi odpowiednio 13 proc. oraz 38 proc., w 2009 r. odsetki te kształtowały się następująco: 12,5 proc., 13,3 proc. oraz 37 proc., a w 2011 r.: 12,8 proc., 12,9 proc. oraz 37 proc.

${ }^{54}$ Definicja kształcenia się w badaniu Kształcenie Dorostych obejmuje dodatkowo także samodzielne dokształcenie się/uczenie.
} 
się w latach 2005-2007 podjęło dalszą aktywność edukacyjną w latach 2007-2009. Oznacza to, że bardzo niewielka część osób - nie więcej niż około 5 proc. - w wieku powyżej 25 lat stale się dokształca, co należy uznać za niepokojący wynik.

Tabela 4.9.26. Uczestnictwo osób $w$ wieku powyżej 25 lat w jakiejkolwiek aktywności zwiqzanej z podnoszeniem kwalifikacji zawodowych lub innych umiejętności w ciagu ostatnich 2 lat wedtug wykształcenia oraz ptci (w proc. osób danej kategorii) w latach 2005-2007, 2007-2009 oraz 2009-2011

\begin{tabular}{lccccc}
\hline Wyszczególnienie & $\begin{array}{c}\text { Co najwyżej } \\
\text { podstawowe }\end{array}$ & $\begin{array}{c}\text { Zasadnicze } \\
\text { zawodowe i } \\
\text { gimnazjum }\end{array}$ & Średnie & $\begin{array}{c}\text { Wyższe i } \\
\text { policealne }\end{array}$ & Ogółem \\
\hline Ogółem & 1,3 & $2005-2007$ & & & \\
Kobiety & 0,8 & 4,7 & 11,4 & 30,7 & 11,7 \\
Mężczyźni & 1,9 & 3,0 & 10,8 & 31,3 & 11,9 \\
& & 5,8 & 12,2 & 29,7 & 11,2 \\
Ogółem & 1,1 & $2007-2009$ & & & 11,9 \\
Kobiety & 0,7 & 4,8 & 12,0 & 30,6 & 11,6 \\
Mężczyźni & 1,5 & 2,9 & 10,3 & 30,3 & 12,2 \\
Ogółem & 1,5 & $2009-2011$ & 14,2 & 31,1 & 10,7 \\
Kobiety & 1,1 & 4,0 & 8,9 & 27,5 & 10,8 \\
Mężczyźni & 2,1 & 3,3 & 7,4 & 27,6 & 27,2 \\
\hline
\end{tabular}

\subsubsection{Formy doksztatcania zawodowego}

Analiza form dokształcania zawodowego wraz $\mathrm{z}$ analizą osób uczestniczących w dokształcaniu się pozwala na wskazanie tych form, które powinny być rozwijane. Należy jednak podkreślić, że Diagnoza Społeczna nie zawiera informacji, czy szkolenie było podejmowane z własnej inicjatywy czy nie, a ponadto respondent mógł uczestniczyć w kilku formach edukacyjnych. Dodatkowo informacje o źródłach finansowania także nie są precyzyjne55.

Dane zawarte w tabeli 4.9.27 świadczą o tym, że podnoszenie kwalifikacji zawodowych czy innych umiejętności przez osoby w wieku 25 lat i więcej przyjmuje najczęściej formę kursów finansowanych przez pracodawcę (około 36 proc. wskazań w latach 2005-2007, blisko 40 proc. w 2007-2009 oraz 41 proc. w latach 20092011). Szkolenia, na które kieruje pracodawca, są zwykle najskuteczniejsze ze względu na perspektywy zatrudnienia. Około 15 proc. respondentów wskazało na szkoły czy uczelnie wyższe (z pominięciem studiów doktoranckich) w porównaniu 20 proc. w latach 2005-2007 i 2007-2009. Ten spadek może być związany z aspiracjami edukacyjnymi młodzieży, która chce kontynuować naukę bezpośrednio po ukończeniu szkoły średniej i coraz więcej osób w tym wieku legitymuje się wykształceniem wyższym. Nieco częściej niż okresie 2005-2007 korzystano z kursów doszkalających finansowanych ze środków własnych (13 proc. wobec 10 proc.), dwukrotnie częściej niż z kursów dofinansowywanych z Europejskiego Funduszu Społecznego (EFS). Niezmiennie około 7-8 proc. respondentów wskazało na podejmowanie aktywności edukacyjnej związanej z podnoszeniem innych umiejętności np. nauka jazdy, a zaledwie około 5-6 proc. respondentów korzystało ze szkoleń finansowanych z Funduszu Pracy (FP).

Zakres korzystania $\mathrm{z}$ różnych form dokształcania świadczy także o selektywności tego procesu. Najwięcej respondentów wskazuje na działania finansowane przez pracodawcę, co wskazuje, że kwalifikacje podnoszą głównie osoby pracujące (szerzej na ten temat piszemy rozdz. 4.9.6.5.

Zwrócić należy uwagę także na działania finansowane z Europejskiego Funduszu Społecznego (EFS). Choć EFS wdrażany jest w Polsce od kilku lat, to udział osób biorących udział w działaniach finansowanych z EFS przekroczył udział uczestniczących w szkoleniach finansowanych z Funduszu Pracy. Należy jednak wziąć pod uwagę, że grupy docelowe działań EFS są szersze niż FP (obejmują także osoby już pracujące), co przy małych liczebnościach odpowiednich grup uniemożliwia szczegółowe porównania. Pomimo okresu najintensywniejszego wdrażania EFS z perspektywy finansowej 2007-201356, w którym Polska uzyskała znaczną część środków z tego funduszu, w minionych dwóch latach zakres dofinansowania z tego źródła nieznacznie tylko zwiększył się.

\footnotetext{
55 Znaczna część działań edukacyjnych ludności dorosłej współfinansowana jest z 2 lub więcej źródeł. Natomiast kafeteria odpowiedniego pytania Diagnozy Społecznej może sugerować rozłączność źródeł finansowania. Trudno więc jest określić czy respondent wskazując na to, że finansował działanie edukacyjne, odzwierciedla stan faktyczny czy np. to, ze jego wkład był dla niego bardziej odczuwalny niż inne źródła i dlatego je pominął.

${ }^{56}$ www.efs.gov.pl. 
Tabela 4.9.27. Osoby $w$ wieku 25 lat $i$ więcej uczestniczqce w jakiejkolwiek aktywności zwiqzanej z podnoszeniem kwalifikacji zawodowych czy innych umiejętności w latach 2005-20011 wedtug formy doksztatcania się 57

\begin{tabular}{lccc}
\hline \multicolumn{1}{c}{ Forma dokształcania } & \multicolumn{2}{c}{ Odsetek wskazań na daną formę kształcenia w } \\
& \multicolumn{2}{c}{ latach } \\
& $2005-2007$ & $2007-2009$ & $2009-2011$ \\
& 19,9 & 19,1 & 15,3 \\
Nauka w szkołach lub uczelniach wyższych bez studiów & & 10,1 & 8,9 \\
podyplomowych i doktoranckich & 7,9 & 10,0 & 13,3 \\
Studia podyplomowe i doktoranckie & 15,1 & 6,1 & 7,3 \\
Kursy doszkalające finansowane ze środków własnych & 7,1 & 5,2 & 6,5 \\
Kursy doszkalające finansowane ze środków EFS & 5,7 & 39,6 & 40,8 \\
Kursy doszkalające finansowane ze środków FP & 36,5 & 7,0 & 7,9 \\
Kursy doszkalające finansowane ze środków pracodawcy & 7,8 & 7,0 \\
Inne formy doskonalenia umiejętności (np. prawo jazdy) & &
\end{tabular}

Należy jednak pamiętać, że wiele działań edukacyjnych jest współfinansowanych z różnych źródeł np. ze środków pracodawcy i środków własnych. W pytaniu zadanym w Diagnozie Społecznej w latach 2007, 2009 i 2011 nie przewidziano odpowiedzi dotyczącej współfinansowania, więc dane zawarte w tabeli 4.9.27 należy traktować jako pewne przybliżenie znaczenia poszczególnych źródeł finansowania.

Ze względu na małe liczebności dla poszczególnych form dokształcania niemożliwe jest przeprowadzenie analizy form dokształcania się według statusu na rynku pracy respondenta, w szczególności dla osób niepracujących.

\subsubsection{Kwalifikacje zawodowe a status na rynku pracy lata 2000-2011}

Analiza osób, które nie pracowały z powodu braku kwalifikacji odpowiadających pracodawcom oraz osób pracujących pozwoli na przynajmniej częściową ocenę skali niedopasowań strukturalnych na rynku pracy w odniesieniu do kwalifikacji zawodowych posiadanych przez osoby w wieku produkcyjnym. Pamiętać jednak należy, iż jest to subiektywna ocena respondentów, która zapewne odbiega od oceny pracodawców.

Ze względu na sposób ujęcia pytań o przyczyny niewykonywania pracy zawodowej w kwestionariuszu porównania można przeprowadzić dla trzech okresów: 2000-2007, 2005-2009 oraz 2007-2011. Mimo braku ich rozłączności można uznać, że pierwszy okres obejmuje głownie lata spowolnienia polskiej gospodarki (2002-2004), drugi - lata stosunkowo dobrej koniunktury gospodarczej, choć już zapewne skutki kryzysu gospodarczego mogły wpływać na odpowiedzi respondentów, a trzeci okres przypada na lata spowolnienia gospodarczego wywołanego kryzysem.

Wśród osób niepracujących zawodowo w latach 2000-2007, czyli osób bezrobotnych i biernych, zaledwie około 4 proc. wskazało na brak kwalifikacji wymaganych przez pracodawcę58, z czego większość stanowiły kobiety (około 57 proc.) (tabela 4.9.28). W okresie 2005-2009 sytuacja była analogiczna (około 5 proc. respondentów, w tym 54 proc. kobiet). Natomiast w okresie 2007-2011 około 3 proc. uznało brak kwalifikacji jako przyczynę pozostawania bez pracy, z czego aż około 62 proc. stanowiły kobiety.

Należy pamiętać, że jest to subiektywna ocena respondenta, więc przewaga kobiet może wynikać z większego ich krytycyzmu. Na ten wynik może też wpływać znaczenie wykształcenie jako determinanty zatrudnienia, większe dla kobiet niż mężczyzn (np. Sztanderska, Grotkowska, 2007).

Wśród niepracujących zawodowo $\mathrm{z}$ powodu braku kwalifikacji w latach 2007-2011 18 proc. miało wykształcenie co najwyżej podstawowe, mniej niż w okresach poprzednich (około 24 proc.). Z kolei aż 48 proc. legitymowało się wykształceniem zasadniczym zawodowym (wobec 40-42 proc. poprzednio). Lącznie ta grupa stanowiła niezmiennie około dwie trzecie niepracujących z powodu braku kwalifikacji. Około 27-28 proc. niepracujących miało wykształcenie średnie, zaś najmniej było osób z wykształceniem wyższym (6 proc. w latach 2000-2007, 9 proc. w latach 2005-2009 oraz blisko 7 proc. w latach 2007-2011).

Struktura respondentów o kwalifikacjach niewystarczających do wykonywania pracy zawodowej według miejsca zamieszkania jest zbliżona $\mathrm{w}$ trzech wyróżnionych okresach. Osoby niepracujące $\mathrm{z}$ powodu braku odpowiednich kwalifikacji pochodziły głównie ze wsi (około 36 proc. w latach 2000-2007 oraz 43 proc. w następnych okresach) oraz miast liczących do 100 tys. mieszkańców (około 37 proc. w latach 2000-2007 oraz 32 proc. w następnych okresach). Około co piąta osoba o niewystarczających kwalifikacjach pochodziła z miast średnich, zaś odsetek osób o niewystarczających kwalifikacjach z miast dużych i średnich nie przekraczał 9 proc. we wszystkich analizowanych okresach.

\footnotetext{
${ }^{57}$ Respondent mógł wymienić trzy aktywności, które podjął w ciągu 2 ostatnich lat w celu podnoszenia swych kwalifikacji zawodowych czy innych umiejętności. Do analiz użyto formy wymienione jako pierwsze - najważniejsze.

${ }^{58}$ Ankietowani mogli wskazać więcej niż jeden powód pozostawania bez pracy, odsetek wskazań informuje więc o randze danego powodu. 
Tabela 4.9.28. Struktura osób niepracujacych w latach 2000-20011, dla których przyczyna pozostawania bez pracy byt brak wymaganych przez pracodawce kwalifikacji, wedtug płci, wykształcenia, miejsca zamieszkania $i$ wieku (w proc.)

\begin{tabular}{|c|c|c|c|}
\hline \multirow[t]{2}{*}{ Cechy demograficzno-społeczne } & \multicolumn{3}{|c|}{$\begin{array}{l}\text { Odsetek osób niepracujących z powodu braku kwalifikacji odpowiadających } \\
\text { pracodawcom (ocena subiektywna respondenta) w latach }\end{array}$} \\
\hline & $2000-2007$ & $2005-2009$ & $2007-2011$ \\
\hline Ogółem, w tym: & 4,2 & 4,9 & 2,9 \\
\hline Kobiety & 57,4 & 54,1 & 61,8 \\
\hline Mężczyźni & 42,6 & 45,7 & 38,2 \\
\hline Wyższe i policealne & 6,0 & 9,2 & 6,7 \\
\hline Średnie & 28,6 & 27,0 & 27,1 \\
\hline Zasadnicze zawodowe i gimnazjalne & 42,0 & 39,8 & 48,2 \\
\hline Podstawowe i poniżej & 23,4 & 23,8 & 18,0 \\
\hline Miasta powyżej 500 tys. mieszkańców & 7,2 & 8,3 & 8,4 \\
\hline Miasta od 200 do 500 tys. mieszkańców & 14,5 & 9,7 & 8,8 \\
\hline Miasta od 100 do 200 tys. mieszkańców & 5,6 & 7,6 & 7,7 \\
\hline Miasta od 20 do 100 tys. mieszkańców & 22,9 & 20,2 & 20,7 \\
\hline Miasta poniżej 20 tys. mieszkańców & 13,6 & 11,5 & 11,2 \\
\hline Wieś & 36,2 & 42,7 & 43,2 \\
\hline do 24 lat & 41,8 & 25,8 & 37,7 \\
\hline 25-29 lat & 9,3 & 16,3 & 11,3 \\
\hline 30-34 lata & 7,8 & 9,4 & 9,2 \\
\hline 35-39 lat & 7,5 & 7,3 & 5,6 \\
\hline 40-44 lata & 10,0 & 9,5 & 7,4 \\
\hline 45-49 lat & 7,4 & 9,4 & 6,0 \\
\hline 50-54 lata & 9,1 & 11,7 & 7,7 \\
\hline 55 lat $\mathrm{i}$ więcej & 7,1 & 10,6 & 15,1 \\
\hline
\end{tabular}

Struktury wieku osób niepracujących z powodu niewystarczających kwalifikacji różniły się głównie ze względu na udział osób do 29 lat. Udział osób z poszczególnych pięcioletnich grup wieku powyżej 30 roku życia był stosunkowo stabilny i oscylował między 7-12 proc., nie przekraczając różnicy około 3 p.p. dla trzech porównywanych okresów. Natomiast w latach 2005-2009 znacząco zmniejszył się udział osób najmłodszych w porównaniu z okresem 2000-2007 (z 50 proc. do 42 proc.), by w latach 2007-2011 powrócić do poziomu około 50 proc. Udział osób w wieku niemobilnym (45 lat i więcej) był niższy od udziału osób młodych (około 24 proc. w latach 2000-2007, 32 proc. w latach 2005-2009 i 28 proc. w latach 2007-2011), co zdaje się wskazywać na relatywnie gorszą sytuację osób młodych niepracujących pod względem deficytu kwalifikacji zawodowych.

Ponadto wśród niepracujących z powodu braku odpowiednich kwalifikacji w latach 2000-2007 jedynie około 26 proc. uczestniczyło $\mathrm{w}$ jakiejkolwiek aktywności związanej z podnoszeniem swoich kwalifikacji w ciągu dwóch ostatnich lat poprzedzających daną rundę badania (kobiety blisko 24 proc., mężczyźni 29 proc.). Informacja ta jest niepełna, ponieważ dane o podejmowaniu aktywności edukacyjnej nie dotyczą całego okresu, w którym kwalifikacje respondenta były niewystarczające. Dla lat 2005-2009 i 2007-2011 dysponujemy już pełną informacją dotyczącą podejmowania aktywności edukacyjnej przez osoby o niewystarczających do podjęcia zatrudnienia kwalifikacjach. Jedynie około 27 proc. niepracujących z powodu braku odpowiednich kwalifikacji w latach 20052009 oraz 2007-2011 było aktywnych edukacyjnie w tym okresie.

Podsumowując, wśród osób niepracujących $\mathrm{z}$ powodu braku wymaganych kwalifikacji we wszystkich wyodrębnionych okresach zdecydowaną większość stanowiły osoby o wykształceniu co najwyżej zasadniczym zawodowym, mieszkające na wsi lub w miastach małych i średnich. Około połowa z nich nie skończyła 30 lat. Blisko trzy czwarte nie podjęło żadnej aktywności, by zmniejszyć deficyt kapitału ludzkiego i podnieść swoje kwalifikacje i umiejętności zawodowe.

\subsubsection{Inne przyczyny pozostawania kiedykolwiek bez pracy w latach 2000-2011}

Z naszych analiz wynika, że w ocenie respondentów niedostosowanie kwalifikacji do wymagań pracodawcy ma generalnie niewielkie znaczenie jako przyczyna pozostawania bez pracy. Pojawia się zatem pytanie, jakie znaczenie mają pozostałe przyczyny. Odwołanie się do tych samych cech demograficzno-społecznych powinno dostarczyć odpowiedzi na to pytanie.

Zgodnie z oczekiwaniami ranga różnych przyczyn jest odmienna dla kobiet i mężczyzn oraz zmienia się dla różnych grup wieku (tabela 4.9.29).

Wśród podstawowych przyczyn pozostawania bez pracy największe znaczenie miały przyczyny związane w wiekiem: nauka w najmłodszych grupach wieku (24-27 proc. wskazań) oraz emerytura w grupach najstarszych (odpowiednio 34 proc., 40 proc. i 43 proc.). Stosunkowo często wskazywano niezmiennie na zdrowie (14-16 proc.), 
a także na trudności ze znalezieniem pracy (14-16 proc. w latach 2000-2007 i 2005-2009, 10 proc. w latach 20072011). Pozostałe przyczyny były wskazywane przez kilka procent respondentów.

Tabela 4.9.29. Struktura osób niepracujacych wedtug płci $i$ wieku oraz wybranych przyczyn pozostawania bez pracy w latach 2000-2011 (w proc. danej grupy ludności)

\begin{tabular}{|c|c|c|c|c|c|c|c|c|c|c|}
\hline Wiek/ płeć & Nauka & $\begin{array}{c}\text { Zajmowa- } \\
\text { nie się } \\
\text { domem }\end{array}$ & $\begin{array}{c}\text { Opieka } \\
\text { nad } \\
\text { dziećmi }\end{array}$ & $\begin{array}{l}\text { Zdro- } \\
\text { wie }\end{array}$ & $\begin{array}{c}\text { Nieodpo } \\
\text {-wiedni } \\
\text { wiek }\end{array}$ & $\begin{array}{c}\text { Emery- } \\
\text { tura }\end{array}$ & $\begin{array}{l}\text { Trudności } \\
\text { ze zna- } \\
\text { lezieniem } \\
\text { pracy }\end{array}$ & $\begin{array}{l}\text { Otrzymywa- } \\
\text { nie } \\
\text { świadczeń } \\
\text { społecznych }\end{array}$ & $\begin{array}{c}\text { Brak } \\
\text { chęci do } \\
\text { pracy }\end{array}$ & $\begin{array}{l}\text { Opieka nad } \\
\text { niepełno- } \\
\text { sprawnymi/ } \\
\text { starszymi } \\
\text { członkami } \\
\text { gosp. dom. }\end{array}$ \\
\hline
\end{tabular}

\begin{tabular}{|c|c|c|c|c|c|c|c|c|c|c|}
\hline \multicolumn{11}{|c|}{$2000-2007$} \\
\hline Ogółem & 24,3 & 7,1 & 6,5 & 15,7 & 11,6 & 33,9 & 13,9 & 4,3 & 2,4 & 1,85 \\
\hline Kobiety & 53,1 & 96,1 & 96,1 & 57,2 & 66,6 & 37,9 & 58,4 & 57,2 & 63,1 & \\
\hline Mężczyźni & 46,9 & 3,9 & 3,9 & 42,8 & 33,4 & 62,1 & 41,6 & 42,8 & 36,9 & \\
\hline $15-24$ & 90,6 & $4,2 *$ & $11,7^{*}$ & & 29,8 & & $20,3 *$ & & $36,7 *$ & \\
\hline
\end{tabular}

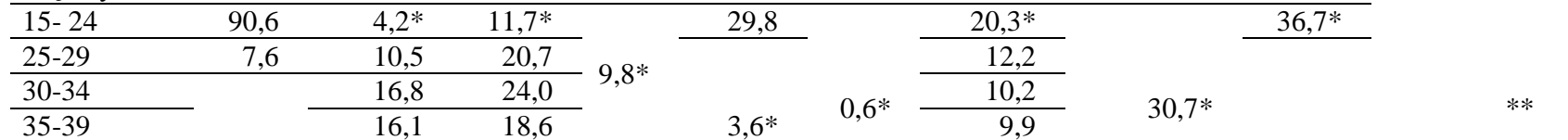

\begin{tabular}{|c|c|c|c|c|c|c|c|c|c|c|}
\hline \multirow{2}{*}{\multicolumn{2}{|c|}{$\frac{50-54}{35-39}$}} & & & & \multirow{4}{*}{$3,6^{*}$} & \multirow{2}{*}{$0,6^{*}$} & & \multirow{2}{*}{$30,7 *$} & \multirow{6}{*}{$63,3 *$} & \multirow{2}{*}{$* *$} \\
\hline & & 16,1 & 18,6 & & & & 9,9 & & & \\
\hline $40-44$ & \multirow{4}{*}{$1,8^{*}$} & 12,0 & 11,0 & 3,9 & & & 10,2 & & & \\
\hline $45-49$ & & 11,2 & 5,4 & 9,6 & & & 9,5 & & & \\
\hline $50-54$ & & 14,2 & 5,0 & 17,3 & 6,0 & 2,1 & 14,2 & 17,8 & & \\
\hline $55+$ & & 14,9 & 3,7 & 59,4 & 60,6 & 97,3 & 13,4 & 52,0 & & \\
\hline \multicolumn{11}{|c|}{$2005-2009$} \\
\hline Ogółem & 25,6 & 8,4 & 9,0 & 15,7 & 12 & 40,4 & 15,5 & 4,4 & 3,8 & 2,5 \\
\hline Kobiety & 50,5 & 92,4 & 95,6 & 51,7 & 66,7 & 62,0 & 54,4 & 55,2 & 57,6 & 77,3 \\
\hline Mężczyźni & 49,5 & 7,6 & 4,4 & 48,2 & 33,2 & 38,0 & 45,6 & 44,6 & 42,4 & 22,7 \\
\hline do 24 lat & 89,1 & 7,6 & 13,3 & \multirow{2}{*}{$5,1^{*}$} & 26,1 & \multirow{6}{*}{$1,3^{*}$} & 16,1 & \multirow{2}{*}{$11,6^{*}$} & 28,6 & \multirow{5}{*}{$31,7 *$} \\
\hline $25-29$ & 9,0 & 11,3 & 23,2 & & \multirow{5}{*}{$3,6^{*}$} & & 15,1 & & 16,2 & \\
\hline $30-34$ & \multirow{6}{*}{$1,9^{*}$} & 15,9 & 26,2 & \multirow{2}{*}{$5,5^{*}$} & & & 10,8 & \multirow{3}{*}{$11,5^{*}$} & \multirow{5}{*}{$20,7 *$} & \\
\hline $35-39$ & & 14,5 & 18,5 & & & & 9,2 & & & \\
\hline $40-44$ & & 11,1 & 7,8 & 4,8 & & & 8,9 & & & \\
\hline $45-49$ & & 10,2 & 5,3 & 7,6 & & & 10,7 & \multirow[b]{2}{*}{$20,0 *$} & & \multirow{2}{*}{$33,2 *$} \\
\hline $50-54$ & & 12,6 & \multirow{2}{*}{$5,7^{*}$} & 17,6 & 5,5 & 2,3 & 15,5 & & & \\
\hline $55+$ & & 16,8 & & 59,3 & 64,8 & 96,4 & 13,7 & 57,0 & 34,6 & 35,1 \\
\hline \multicolumn{11}{|c|}{$2007-2011$} \\
\hline Ogółem & 26,6 & 6,5 & 6,3 & 13,7 & 8,9 & 43,5 & 9,8 & 3,1 & 2,7 & 1,5 \\
\hline Kobiety & 53,5 & 96,1 & 98,1 & 50,0 & 72,1 & 63,7 & 59,2 & 62,9 & 64,2 & 75,5 \\
\hline Mężczyźni & 46,5 & 3,9 & 2,9 & 50,0 & 27,9 & 36,3 & 40,8 & 37,1 & 35,9 & 24,5 \\
\hline $15-24$ & 92,5 & 4,7 & 9,4 & \multirow{2}{*}{$5,6^{*}$} & 27,4 & \multirow{5}{*}{$0^{*}$} & 19,2 & \multirow{6}{*}{$15,9 *$} & 21,3 & \multirow{5}{*}{$28,6^{*}$} \\
\hline $25-29$ & 6,5 & 8,5 & 18,1 & & \multirow{5}{*}{$1,9^{*}$} & & 17,9 & & \multirow{2}{*}{$13,6^{*}$} & \\
\hline $30-34$ & \multirow{6}{*}{$0,9^{*}$} & 15,5 & 32,1 & \multirow{2}{*}{$5,0 *$} & & & 6,9 & & & \\
\hline $35-39$ & & 10,6 & 15,2 & & & & 6,3 & & & \\
\hline $40-44$ & & 11,5 & 9,4 & 4,8 & & & 5,1 & & $14,0^{*}$ & \\
\hline $45-49$ & & 12,6 & 6,3 & 6,6 & & $11 *$ & 9,9 & & & $367 *$ \\
\hline $50-54$ & & 13,8 & & 17,2 & 4,2 & $1,1^{*}$ & 14,0 & 14,9 & & $36,1 *$ \\
\hline $55+$ & & 22,8 & $9,6^{*}$ & 60,8 & 66,5 & 98,7 & 20,8 & 69,2 & $50,6^{*}$ & 34,7 \\
\hline
\end{tabular}

Uwaga: Respondent mógł wskazać maksymalnie 3 przyczyny.

* łączenie grup wieku ze względu na małe liczebności

** zbyt małe liczebności do analizy struktury według cech społeczno - gospodarczych

Struktura respondentów niepracujących z określonej przyczyny jest silnie determinowana fazą przebiegu życia w porównywalnych okresach: wśród niepracujących z powodu nauki dominują osoby młode do 24 roku życia, zaś wśród niepracujących z powodu emerytury przeważają wyraźnie osoby powyżej 60 roku życia.

Opieka nad dziećmi, zajmowanie się domem czy sprawowanie opieki nad starszymi lub niepełnosprawnymi członkami gospodarstw są podawane jako powód pozostawania bez pracy właściwie tylko przez kobiety, co wskazuje wciąż na silne uwarunkowania kulturowe powiązania pracy zawodowej i obowiązków domowych. Struktura niepracujących według wieku ze względu na trudności ze znalezieniem zatrudnienia jest stosunkowo równomierna, $\mathrm{z}$ niewielką przewagą osób $\mathrm{w}$ najmłodszych grupach wieku, tj. do 24 roku życia. Wśród niepracujących z powodu kłopotów ze zdrowiem zdecydowanie dominują osoby w wieku powyżej 54 lat. Ponadto, potwierdzi się też destymulujący wpływ otrzymywanych świadczeń społecznych zarówno wśród osób w wieku 1549 lat, jak i w wieku 50-59 lat. Ustalenie, jakie świadczenia otrzymywali respondenci i powiązanie ich z pozostawaniem bez pracy jest jednak niemożliwe. Stosowne pytanie skierowane było bowiem do osób, które kiedykolwiek nie pracowały w latach 2000-2007 i 2005-2009, przy czym nie dezagregowano świadczeń w kafeterii 
odpowiedzi. Analogicznie wygląda sytuacja wśród niepracujących z powodu braku chęci do pracy - także w tej grupie dominują kobiety.

Respondentów niepracujących zawodowo w latach 2005-2009 oraz 2007-2011 zapytano dodatkowo o warunki, które skłoniłyby ich do podjęcia pracy zawodowej w kraju (tabela 4.9.30). Analiza warunków podjęcia zatrudniania przez osoby niepracujące jest niezmiernie ważna biorąc pod uwagę niskie wskaźniki zatrudnienia w Polsce, szczególnie dla grup znajdujących się w mniej korzystnej sytuacji na rynku pracy, a więc - między innymi - kobiet oraz osób starszych.

Około połowa niepracujących kiedykolwiek w latach 2005-2009 i 2007-2011 nie chciała pracować, częściej w latach 2007-2011 niż w poprzednim okresie. Na inne niż wymienione kwestionariuszu powody wskazało prawie 22 proc. w latach 2005-2009 i 16 proc. w latach 2007-2011. Spośród pozostałych warunków podjęcia pracy możliwość zatrudnienia w niepełnym wymiarze czasu pracy oraz elastyczny czas pracy podawane były stosunkowo często (1314 proc. respondentów w latach 2005-2009 i 10-12 proc. w latach 2007-2011), rzadziej wskazywano na możliwość wykonywania pracy w domu (9 proc. respondentów w latach 2005-2009 i 7 proc. w latach 2007-2011).

Tabela 4.9.30. Struktura osób niepracujacych wedtug płci i wieku oraz warunków podjęcia pracy w latach 2007 -

2011(w proc. danej grupy ludności)

\begin{tabular}{|c|c|c|c|c|c|c|c|c|c|}
\hline Wiek/ płeć & $\begin{array}{c}\text { Niepełny } \\
\text { wymiar } \\
\text { czasu } \\
\text { pracy }\end{array}$ & $\begin{array}{c}\text { Możliwość } \\
\text { wykonywania } \\
\text { części pracy w } \\
\text { domu }\end{array}$ & $\begin{array}{l}\text { Elastyczny } \\
\text { czas pracy }\end{array}$ & $\begin{array}{l}\text { Większa } \\
\text { pomoc } \\
\text { członków } \\
\text { rodziny w } \\
\text { obowiązkach } \\
\text { domowych }\end{array}$ & $\begin{array}{l}\text { Możliwość } \\
\text { opieki nad } \\
\text { dziećmi lub } \\
\text { chorymi }\end{array}$ & $\begin{array}{c}\text { Możliwość } \\
\text { zachowania } \\
\text { prawa do } \\
\text { świadczeń } \\
\text { społecznych }\end{array}$ & $\begin{array}{c}\text { Dogodne } \\
\text { warunki } \\
\text { dojazdu i } \\
\text { pracy dla osób } \\
\text { niepełno- } \\
\text { sprawnych }\end{array}$ & Inne & $\begin{array}{c}\text { Brak } \\
\text { chęci } \\
\text { do } \\
\text { pracy }\end{array}$ \\
\hline
\end{tabular}

\begin{tabular}{|c|c|c|c|c|c|c|c|c|c|}
\hline \multicolumn{10}{|c|}{ 2005-2009 } \\
\hline Ogółem & 13,4 & 8,8 & 14 & 3,3 & 3,7 & 5,9 & 3,2 & 22,1 & 48,2 \\
\hline Mężczyźni & 35,8 & 32,9 & 41,7 & 20,0 & 12,0 & 50,3 & 58,1 & 52,2 & 36,5 \\
\hline Kobiety & 64,2 & 67,1 & 58,3 & 80,0 & 88,0 & 49,7 & 41,9 & 47,8 & 63,5 \\
\hline do 24 lat & 27,8 & 27,6 & 44,8 & 21,0 & 18,0 & \multirow{2}{*}{$17,0^{*}$} & 11,7 & 41,0 & 13 \\
\hline 25-29 lat & 8,5 & 9,8 & 14,0 & 21,4 & 21,9 & & 6,2 & 10,0 & 1,0 \\
\hline 30-34 lata & 6,8 & 9,1 & 9,5 & 17,0 & 20,3 & \multirow{2}{*}{$6,8^{*}$} & \multirow{2}{*}{$11,4^{*}$} & 5,1 & \multirow{2}{*}{$1,2 *$} \\
\hline 35-39 lata & 6,3 & 8,5 & 6,7 & 10,0 & 15,3 & & & 5,1 & \\
\hline 40-44 lata & 4,2 & 7,4 & 5,0 & \multirow{2}{*}{$16,2 *$} & \multirow{2}{*}{$12,0^{*}$} & \multirow{2}{*}{$12,3^{*}$} & 7,6 & 6,0 & 0,9 \\
\hline 45-49 lata & 5,2 & 7,2 & 4,6 & & & & 8,6 & 6,8 & 1,5 \\
\hline 50-54 lata & 9,2 & 8,9 & 5,6 & \multirow{2}{*}{$14,3 *$} & \multirow{2}{*}{$12,6^{*}$} & 14,9 & 23,1 & 8,1 & 3,9 \\
\hline $55+$ & 32,0 & 21,4 & 10,2 & & & 48,9 & 31,4 & 17,9 & 78,4 \\
\hline \multicolumn{10}{|c|}{$2007-2011$} \\
\hline Ogółem & 11,7 & 7,0 & 10,1 & 0,3 & 2,6 & 4,3 & 2,6 & 16,0 & 56,6 \\
\hline Mężczyźni & 34,9 & 31,0 & 40,8 & 14,1 & 9,6 & 44,0 & 44,0 & 45,4 & 35,9 \\
\hline Kobiety & 65,1 & 69,0 & 59,2 & 85,9 & 90,4 & 56,0 & 56,0 & 54,6 & 64,1 \\
\hline do 24 lat & 34,5 & 34,8 & 60,4 & 16,0 & 22,3 & \multirow{2}{*}{$17,0^{*}$} & 17,0 & 50,5 & 13,3 \\
\hline 25-29 lat & 5,9 & 9,1 & 10,2 & 15,6 & 17,1 & & 4,2 & 7,3 & \multirow{2}{*}{$1,3^{*}$} \\
\hline 30-34 lata & 6,5 & 8,3 & 4,7 & 19,1 & 29,5 & \multirow{2}{*}{$6,6^{*}$} & \multirow{2}{*}{$4,9^{*}$} & 3,1 & \\
\hline 35-39 lata & 4,5 & 5,2 & 4,3 & 15,1 & 8,8 & & & 2,4 & \\
\hline 40-44 lata & 3,0 & 4,3 & 3,1 & \multirow{2}{*}{$15,0^{*}$} & \multirow{2}{*}{$10,4^{*}$} & \multirow{2}{*}{$14,3 *$} & 4,9 & 4,3 & $1,1^{*}$ \\
\hline 45-49 lata & 4,3 & 5,4 & & & & & 5,7 & 4,3 & 1,2 \\
\hline 50-54 lata & 7,9 & 7,6 & $5,4^{*}$ & \multirow{2}{*}{$19,1^{*}$} & \multirow{2}{*}{$12,0^{*}$} & 8,6 & 8,6 & 7,4 & 3,0 \\
\hline $55+$ & 33,5 & 25,2 & 11,9 & & & 54,8 & 54,8 & 20,6 & 80,0 \\
\hline
\end{tabular}

Uwaga: Respondent mógł wskazać maksymalnie 2 warunki

* łączenie grup wieku ze względu na małe liczebności

Rozkład respondentów według wieku, którzy wskazali na istnienie warunków skłaniających ich do podjęcia pracy jest w dużej mierze determinowany przebiegiem życia jednostki i podziałem ról w rodzinie. Wśród osób wskazujących na możliwość pracy w niepełnym wymiarze czasu, wykonywanie pracy w domu, elastyczny czas pracy, większą pomoc członków rodziny w obowiązkach domowych czy możliwość uzyskania opieki nad dziećmi lub chorymi jednoznacznie dominują kobiety z młodszych i starszych grup wieku. Kobiety młodsze opiekują się dziećmi i je wychowują, starsze natomiast opiekują się osobami starszymi czy wnukami. Wśród osób, które wskazały, że do pracy skłoniłaby je możliwość zachowania świadczeń społecznych około połowa to osoby w wieku powyżej 55 lat, a wskaźnik ten wskazuje na tendencję wzrostową w okresie 2007-2011. Dla tych osób możliwość łączenia pracy z pobieraniem emerytury byłaby czynnikiem aktywizującym, co w obliczu procesu starzenia się ludności nabiera istotnego znaczenia. Niepokojący jest natomiast wyjątkowy duży i rosnący odsetek wskazań na brak chęci do pracy, który w ostatnim analizowanym okresie istotnie wzrósł (około 48 proc. dla okresu 2005-2009, 56 proc. dla okresu 2007-2011). W tej grupie respondentów zdecydowanie dominują osoby powyżej 55 roku życia (78-80 proc.) we wszystkich analizowanych okresach. 


\subsubsection{Aktywność edukacyjna osób dorostych a dynamika rynku pracy}

Znaczenie dokształcania się dla statusu na rynku pracy potwierdziły analizy przepływów na rynku pracy pomiędzy trzema stanami: pracujący, bezrobotni oraz bierni zawodowo, które przeprowadzone zostały na podstawie panelowej bazy danych. W Diagnozie Społecznej 2005 dokonano analizy przepływów pomiędzy rokiem 2003 a 2005 dla osób, które skorzystały w 2003 r. z usług edukacyjnych, zarówno w trybie dziennym, zaocznym i eksternistycznym, jak i w formie kursów doszkalających w porównaniu z pozostałą częścią populacji, która nie korzystała z tego typu usług. W analizie przepływów na podstawie danych z edycji Diagnozy Społecznej 2007, 2009 i 2011 posłużono się inną miarą aktywności edukacyjnej, która została wprowadzona dopiero w kwestionariuszu w 2007 roku tj. uczestnictwem w jakiejkolwiek aktywności zawiązanej z podnoszeniem swoich kwalifikacji zawodowych czy innych umiejętności w ciągu ostatnich 2 lat. Rozpatrujemy jedynie osoby w wieku 25-39 lat ze względu na fakt, że aktywność edukacyjna po 39 roku życia znacznie spada i dotyczy marginalnej części populacji. W poniższych tabelach (tabele 4.9.30., 4.9.31., 4.9.32.) przedstawiono dane dla trzech okresów: 2005-2007, 2007-2009 i 20072009, jednak szczegółowy opis dotyczy głównie ostatniego okresu, dla wcześniejszych edycji Diagnozy Społecznej znajduje się on w poprzednich opracowaniach.

Tabela 4.9.30. Przepływy na rynku pracy osób $w$ wieku 25-39 lat wedlug udziału w podnoszeniu kwalifikacji w latach 2005-2011(w proc.)

a) lata 2005-2007

\begin{tabular}{|c|c|c|c|c|}
\hline \multirow{2}{*}{ Stan w marcu 2005} & \multicolumn{4}{|c|}{ Stan w marcu 2007} \\
\hline & Pracujący & Bezrobotni & Bierni & Ogółem \\
\hline \multicolumn{5}{|c|}{ Osoby uczestniczące w podnoszeniu kwalifikacji w ciagu ostatnich 2 lat $(\mathrm{N}=282)$} \\
\hline Pracujący & 67,9 & 2,9 & 3,3 & 74,1 \\
\hline Bezrobotni & 4,4 & 1,8 & 1,8 & 8,0 \\
\hline Bierni & 12,8 & 1,8 & 3,3 & 17,9 \\
\hline Ogółem & 85,1 & 6,5 & 8,4 & 100,0 \\
\hline \multicolumn{5}{|c|}{ Pozostali respondenci $(\mathrm{N}=1141)$} \\
\hline Pracujący & 63,3 & 1,6 & 4,0 & 68,9 \\
\hline Bezrobotni & 8,8 & 3,1 & 2,3 & 14,2 \\
\hline Bierni & 6,6 & 1,8 & 8,5 & 16,9 \\
\hline Ogółem & 78,7 & 6,5 & 14,8 & 100,0 \\
\hline
\end{tabular}

b) lata 2007-2009

\begin{tabular}{lllll}
\multirow{2}{*}{ Stan w marcu 2007 } & \multicolumn{4}{c}{ Stan w marcu 2009 } \\
\cline { 2 - 4 } & Pracujący & Bezrobotni & Bierni & Ogółem \\
\hline
\end{tabular}

\begin{tabular}{|c|c|c|c|c|}
\hline \multirow{2}{*}{\multicolumn{5}{|c|}{ ji w ciagu ostatnich 2 lat $(\mathrm{N}=445)$}} \\
\hline & & & & \\
\hline Pracujący & 75,7 & $2,9 *$ & $2,2 *$ & 80,9 \\
\hline Bezrobotni & $3,4^{*}$ & $1,3 *$ & $0,4^{*}$ & 5,2 \\
\hline Bierni & 7,2 & $0,4^{*}$ & $6,3 *$ & 13,9 \\
\hline Ogółem & 86,3 & 4,7 & 9,0 & 100 \\
\hline \multicolumn{5}{|c|}{ Pozostali respondenci $(\mathrm{N}=1620)$} \\
\hline Pracujący & 67,3 & 3,3 & 3,7 & 74,3 \\
\hline Bezrobotni & 4,3 & 2,5 & 1,4 & 8,1 \\
\hline Bierni & 6,5 & 1,6 & 9,5 & 17,6 \\
\hline Ogółem & 78,0 & 7,4 & 14,6 & 100,0 \\
\hline \multicolumn{5}{|l|}{ lata 2009-20011 } \\
\hline \multirow{2}{*}{ Stan w marcu 2009} & \multicolumn{4}{|c|}{ Stan w marcu 2011} \\
\hline & Pracujący & Bezrobotni & Bierni & Ogółem \\
\hline \multicolumn{5}{|c|}{ Osoby uczestniczące w podnoszeniu kwalifikacji w ciagu ostatnich 2 lat $(\mathrm{N}=806)$} \\
\hline Pracujący & 67,3 & 4,3 & $1,9 *$ & 73,6 \\
\hline Bezrobotni & 4,7 & $1,4 *$ & $0,4 *$ & 6,5 \\
\hline Bierni & 8,4 & 3,8 & 7,7 & 20,0 \\
\hline Ogółem & 80,5 & 9,6 & 9,8 & 100,0 \\
\hline \multicolumn{5}{|c|}{ Pozostali respondenci $(\mathrm{N}=3670)$} \\
\hline Pracujący & 67,6 & 3,1 & 3,2 & 73,9 \\
\hline Bezrobotni & 4,3 & 2,6 & 1,6 & 8,4 \\
\hline Bierni & 5,9 & 1,9 & 9,9 & 17,7 \\
\hline Ogółem & 77,7 & 7,6 & 14,7 & 100,0 \\
\hline
\end{tabular}

* małe liczebności

Wśród osób w wieku 25-39 lat, które w latach 2009-2011 podnosiły swoje kwalifikacje, rozpatrywanych według statusu na rynku pracy w 2009 r. około 74 proc. stanowili pracujący, 20 proc. bierni zawodowo, a około 6,5 proc. bezrobotni (tabela 4.9.30). Dwa lata później w tej grupie było więcej pracujących (około 80 proc.) i mniej biernych zawodowo (około 10 proc.). Udział bezrobotnych zwiększył się do około 9,5 proc. Struktura osób, które nie zdecydowały się na podnoszenie swoich kwalifikacji w tym czasie, rozpatrywanych według statusu zatrudnienia 
w 2009 r. jest zbliżona do osób podnoszących swoje kwalifikacje - pracujący stanowili około 74 proc., bezrobotni około 8 proc., a bierni zawodowo - około 18 proc. W 2011 r. także w tej grupie zwiększył się udział pracujących (do 78 proc.), zaś słabiej niż w grupie aktywnych edukacyjnie zmniejszył się udział biernych zawodowo (do prawie 15 proc.), bierni przy stabilnym udziale bezrobotnych.

Poprawa struktury obu porównywanych grup osób według statusu na rynku pracy polegała na wzroście udziału osób pracujących, silniejszym dla osób podnoszącym swe kwalifikacje, przy równoczesnym spadku udziału osób biernych zawodowo, także wyraźniejszym dla osób aktywnych edukacyjnie. Zmiany te wynikają z większej szansy przejścia do pracujących zarówno ze stanu bierności jak i bezrobocia dla osób aktywnych edukacyjnie. Natomiast zmiany udziału bezrobotnych w obu grupach nie były już tak wyraźne - do wzrostu udziału bezrobotnych wśród osób aktywnych edukacyjnie przyczynił się napływ osób biernych zawodowo.

Te zmiany nieco różnią się od zaobserwowanych we wcześniejszych okresach. Poprawa sytuacji na rynku pracy osób dokształcających się w latach 2005-2007 oraz 2007-2009 polegała na wzroście udziału osób pracujących przy spadku udziału biernych zawodowo i względnie stabilnym udziale osób bezrobotnych. Natomiast dla osób niedokształcających się w latach 2005-2007 zmiana polegała na zwiększeniu się udziału osób pracujących przy znacznym spadku bezrobotnych i względnie stałym udziale osób biernych zawodowo, zaś w latach 2007-2009 zmiana była podobna do zaobserwowanej w ostatnim okresie - więcej było pracujących i mniej biernych, lecz udział bezrobotnych była stabilny.

Tabela 4.9.31. Przeptywy na rynku pracy kobiet $w$ wieku 25-39 lat wedtug udziału w podnoszeniu kwalifikacji w latach 2005-2011(w proc.)

a) lata 2005-2007

\begin{tabular}{|c|c|c|c|c|}
\hline \multirow{2}{*}{ Stan w marcu 2005} & \multicolumn{4}{|c|}{ Stan w marcu 2007} \\
\hline & Pracujący & Bezrobotni & Bierni & Ogółem \\
\hline \multicolumn{5}{|c|}{ Osoby uczestniczące w podnoszeniu kwalifikacji w ciaggu ostatnich 2 lat $(\mathrm{N}=160)$} \\
\hline Pracujący & 62,1 & 1,9 & 4,5 & 68,5 \\
\hline Bezrobotni & 4,5 & 2,6 & 2,6 & 9,7 \\
\hline Bierni & 13,5 & 3,2 & 5,1 & 21,8 \\
\hline Ogółem & 80,1 & 7,7 & 12,2 & 100,0 \\
\hline \multicolumn{5}{|c|}{ Pozostali respondenci $(\mathrm{N}=593)$} \\
\hline Pracujący & 56,6 & 1,4 & 6 & 64 \\
\hline Bezrobotni & 6,8 & 2,2 & 3,4 & 12,4 \\
\hline Bierni & 8,2 & 2,7 & 12,7 & 23,6 \\
\hline Ogółem & 71,6 & 6,3 & 22,1 & 100,0 \\
\hline \multicolumn{5}{|l|}{ lata 2007-2009 } \\
\hline \multirow{2}{*}{ Stan w marcu 2007} & \multicolumn{4}{|c|}{ Stan w marcu 2009} \\
\hline & Pracujący & Bezrobotni & Bierni & Ogółem \\
\hline \multicolumn{5}{|c|}{ Osoby uczestniczące w podnoszeniu kwalifikacji w ciagu ostatnich 2 lat $(\mathrm{N}=219)$} \\
\hline Pracujący & 70,3 & 2,7 & $3,2 *$ & 76,3 \\
\hline Bezrobotni & $6,4^{*}$ & $1,4^{*}$ & - & $7,8 *$ \\
\hline Bierni & $8,7^{*}$ & $0,5^{*}$ & $6,8^{*}$ & 16,0 \\
\hline Ogółem & 85,4 & $4,6^{*}$ & 10,0 & 100,0 \\
\hline \multicolumn{5}{|c|}{ Pozostali respondenci $(\mathrm{N}=840)$} \\
\hline Pracujący & 57,5 & $2,5^{*}$ & 5,1 & 65,1 \\
\hline Bezrobotni & 3,1 & 3,2 & 1,9 & 8,2 \\
\hline Bierni & 9,2 & $2,4 *$ & 15,1 & 26,7 \\
\hline Ogółem & 69,8 & 8,1 & 22,1 & 100,0 \\
\hline
\end{tabular}

c) lata 2009-2011

\begin{tabular}{|c|c|c|c|c|}
\hline \multirow{2}{*}{ Stan w marcu 2009} & \multicolumn{4}{|c|}{ Stan w marcu 2011} \\
\hline & Pracujący & Bezrobotni & Bierni & Ogółem \\
\hline \multicolumn{5}{|c|}{ Osoby uczestniczace w podnoszeniu kwalifikacji w ciagu ostatnich 2 lat $(\mathrm{N}=431)$} \\
\hline Pracujący & 63,1 & 5,6 & $2,3^{*}$ & 71,0 \\
\hline Bezrobotni & 3,7 & $1,4^{*}$ & $0,7 *$ & 5,8 \\
\hline Bierni & 7,9 & 5,3 & 10,3 & 23,2 \\
\hline Ogółem & 74,7 & 12,3 & 13,0 & 100,0 \\
\hline \multicolumn{5}{|c|}{ Pozostali respondenci $(\mathrm{N}=1787)$} \\
\hline Pracujący & 57,4 & 2,7 & 5,3 & 65,4 \\
\hline Bezrobotni & 3,5 & 2,8 & 2,2 & 8,5 \\
\hline Bierni & 8,7 & 2,3 & 15,1 & 26,1 \\
\hline Ogółem & 69,6 & 7,8 & 22,7 & 100,0 \\
\hline
\end{tabular}

* małe liczebności

Wyniki z trzech porównywanych okresów uwidaczniają wpływ podnoszenia kwalifikacji na wzrost aktywności zawodowej wskutek zwiększenia się udziału pracujących i spadku udziału osób biernych zawodowo. 
Podobnie jak w poprzednich okresach osoby pracujące, które były aktywne edukacyjnie w latach 2009-2011, jak i osoby nie podnoszące swoich kwalifikacji, charakteryzowały się zbliżonym poziomem stabilności zatrudnienia - powyżej 90 proc. zarówno dla nie dokształcających się, jak i dla dokształcających się.

Podsumowując, wyniki analiz dla lat 2009-2011, 2007-2009 oraz 2005-2007 wskazały, że poprawa kwalifikacji ma znaczenie dla aktywizacji osób biernych zawodowo. Uczestnictwo w podnoszeniu kwalifikacji zwiększało szanse na znalezienie zatrudnienia przez bezrobotnych w okresie 2007-2009 w odróżnieniu do lat 2005-2007 i 20092011. Natomiast szanse pozostawania w zatrudnieniu były takie same dla obu porównywanych grup osób aktywnych edukacyjnie i niepodejmujących wysiłku podnoszenia swych kwalifikacji.

Dynamika rynku pracy, oceniana na podstawie przepływów miedzy wyodrębnionymi stanami na rynku pracy, jest zróżnicowana według płci (tabele 4.9.31 i 4.9.32). Wśród kobiet w wieku 25-39 lat, które podnosiły swoje kwalifikacje w ciagu ostatnich dwóch lat, udział pracujących wzrósł z 71 proc. do 75 proc., słabiej niż w okresie 2007-2009 (z 76 proc. do 85 proc.), oraz znacząco i silniej spadł udział biernych zawodowo z około 23 proc. do 13 proc. (w okresie 2007-2009 z 16 proc. do 10 proc.). Natomiast wśród mężczyzn, którzy w ciągu ostatnich 2 lat podnosili swoje kwalifikacje, udział pracujących wzrósł z 82 proc. do 85 proc. (w latach 2007-2009 z 86 proc. do około 88 proc.), zaś natomiast udział biernych zawodowo spadł z około 16 proc. do około 6 proc. Wśród aktywnych edukacyjnie mężczyzn udział bezrobotnych pozostał stabilny wobec wzrostu bezrobocia wśród kobiet (z około 6 proc. do około 12 proc.). Wyraźny spadek bierności zawodowej w tej grupie wiąże się zarówno $\mathrm{z}$ napływem do zatrudnienia, jak i napływem biernych zawodowo kobiet do bezrobocia. We wcześniejszych okresach tak istotnych różnic nie zaobserwowano.

Tabela 4.9.32. Przepływy na rynku pracy mężczyzn w wieku 25-39 lat wedtug udziału w podnoszeniu kwalifikacji w latach 2005-2011(w proc.)

a) lata 2005-2007

\begin{tabular}{|c|c|c|c|c|}
\hline \multirow{2}{*}{ Stan w marcu 2005} & \multicolumn{4}{|c|}{ Stan w marcu 2007} \\
\hline & Pracujący & Bezrobotni & Bierni & Ogółem \\
\hline \multicolumn{5}{|c|}{ Osoby uczestniczące w podnoszeniu kwalifikacji w ciagu ostatnich 2 lat $(\mathrm{N}=122)$} \\
\hline Pracujący & 76,7 & 4,3 & $0,9 *$ & 81,9 \\
\hline Bezrobotni & 3,5 & - & $1,7 *$ & 5,2 \\
\hline Bierni & 12,1 & - & $0,8^{*}$ & 12,9 \\
\hline Ogółem & 92,3 & 5,2 & 2,5 & 100,0 \\
\hline \multicolumn{5}{|c|}{ Pozostali respondenci $(\mathrm{N}=593)$} \\
\hline Pracujący & 70,8 & 1,8 & 1,8 & 74,4 \\
\hline Bezrobotni & 10,9 & 4,1 & 1,0 & 16,0 \\
\hline Bierni & 4,8 & 1,0 & 3,8 & 9,6 \\
\hline Ogółem & 86,5 & 6,9 & 6,6 & 100,0 \\
\hline \multicolumn{5}{|l|}{ lata 2007-2009 } \\
\hline \multirow{2}{*}{ Stan w marcu 2007} & \multicolumn{3}{|c|}{ Stan w marcu 2009} & \\
\hline & Pracujący & Bezrobotni & Bierni & Ogółem \\
\hline \multicolumn{5}{|c|}{ Osoby uczestniczące w podnoszeniu kwalifikacji w ciagu ostatnich 2 lat $(\mathrm{N}=225)$} \\
\hline Pracujący & 81,3 & 3,1 & 1,3 & 85,8 \\
\hline Bezrobotni & 0,4 & $0,9 *$ & $0,9 *$ & 2,2 \\
\hline Bierni & 5,8 & $0,4^{*}$ & $5,8 *$ & 12,0 \\
\hline Ogółem & 87,6 & $4,4^{*}$ & $8,0 *$ & 100,0 \\
\hline \multicolumn{5}{|c|}{ Pozostali respondenci $(\mathrm{N}=779)$} \\
\hline Pracujący & 77,9 & 4,1 & $2,2 *$ & 84,2 \\
\hline Bezrobotni & 5,5 & $1,8^{*}$ & $0,6^{*}$ & 8,0 \\
\hline Bierni & $3,6^{*}$ & $0,8^{*}$ & $3,5^{*}$ & 7,8 \\
\hline Ogółem & 87,0 & 6,7 & 6,3 & 100,0 \\
\hline
\end{tabular}

c) lata $2009-2011$

\begin{tabular}{|c|c|c|c|c|}
\hline \multirow{2}{*}{ Stan w marcu 2009} & \multicolumn{3}{|c|}{ Stan w marcu 2011} & \multirow[b]{2}{*}{ Ogółem } \\
\hline & Pracujący & Bezrobotni & Bierni & \\
\hline \multicolumn{5}{|c|}{ Osoby uczestniczace w podnoszeniu kwalifikacji w ciagu ostatnich 2 lat $(\mathrm{N}=376)$} \\
\hline Pracujący & 72,1 & $2,9 *$ & $1,3^{*}$ & 76,3 \\
\hline Bezrobotni & 5,9 & $1,6^{*}$ & - & 7,2 \\
\hline Bierni & 9,0 & $2,4 *$ & $5,1^{*}$ & 16,5 \\
\hline Ogółem & 87,0 & 6,6 & 6,4 & 100,0 \\
\hline \multicolumn{5}{|c|}{ Pozostali respondenci $(\mathrm{N}=1882)$} \\
\hline Pracujący & 77,3 & 3,5 & 1,2 & 82,0 \\
\hline Bezrobotni & 5,0 & 2,4 & $0,9 *$ & 8,2 \\
\hline Bierni & 3,3 & 1,5 & 4,9 & 9,8 \\
\hline Ogółem & 85,6 & 7,4 & 7,0 & 100,0 \\
\hline
\end{tabular}


Struktury kobiet i mężczyzn, którzy nie podnosili swoich kwalifikacji, charakteryzują się generalnie niższym udziałem zatrudnionych i wyższym udziałem bezrobotnych. Ich zmiany w czasie są wyraźnie mniej korzystne. Różnice zmian statusu na rynku pracy wśród osób podnoszących swe kwalifikacje oraz pozostałych są większe dla mężczyzn, wskazując na większą rangę doskonalenia zawodowego dla ich statusu na rynku pracy, co stanowi odwrócenie sytuacji z poprzedniej rundy.

Reasumując, podnoszenie kwalifikacji zawodowych miało wpływ na poprawę statusu na rynku pracy osób biernych zawodowo. Mężczyźni czerpią większe korzyści ze swej aktywności edukacyjnej niż kobiety, co było widoczne zwłaszcza w latach 2009-2011.

\subsubsection{Aktywność edukacyjna a zmiana dochodów gospodarstw domowych osób pracujacych w okresie 2007-2011}

W dotychczasowej analizie skupiono się na badaniu zmian statusu na rynku pracy osób aktywnych i biernych edukacyjnie. Istotnym uzupełnieniem tej analizy jest sprawdzenie, czy poprawa kwalifikacji jest powiązana ze zmianami sytuacji dochodowej osób pracujących, które podjęły wysiłek dokształcania się, a ich status na rynku pracy w ciągu dwóch ostatnich lat nie zmienił się. W obecnej rundzie Diagnozy Społecznej możliwa jest analiza dynamiki zmian osobistego dochodu pracującego respondenta w zależności od tego, czy podjął działania edukacyjne w ciągu ostatnich dwóch lat. W badaniach z 2007 r., 2009 r. i 2011 r. w kwestionariuszu indywidualnym zawarte jest pytanie o osobisty dochód netto respondenta $\mathrm{z}$ ostatnich trzech miesięcy. W analizach $\mathrm{z}$ poprzednich rund Diagnozy Społecznej konieczne było posłużenie się dochodem na osobe w gospodarstwie domowym przy równoczesnej kontroli liczby osób w gospodarstwie domowym. Jednak na dochód w gospodarstwie domowym wpływają także zmiany dochodów uzyskiwanych przez innych członków gospodarstwa domowego, czego nie można było uwzględnić $\mathrm{w}$ analizie dynamiki zmian sytuacji dochodowej respondentów dokształcających się i niedokształcających się w latach 2005-2007.

Niemniej jednak poniższa analiza sytuacji dochodowej respondenta na podstawie jego dochodu osobistego stanowi jedynie opis korelacji pomiędzy zmianami dochodu osobistego a dokształcaniem się i nie pozwala na interpretację przyczynowo-skutkową. Tym bardziej, że dochody te są silnie skorelowane z innymi cechami, jak np. poziom wykształcenia.

W tabelach 4.9.33 i 4.9.34 przedstawiony jest rozkład dochodów osobistych netto ${ }^{59}$ pracujących w 2007 r., 2009 r. oraz w 2011 r. dla dwóch grup respondentów: tych, którzy podnosili swoje kwalifikacje w ciągu ostatnich dwóch lat oraz tych, którzy tego nie czynili, a także dynamika dochodów w latach 2007-2009 oraz 2009-2011. Ze względu na różne zmienne określające dochód użyte $\mathrm{w}$ analizach $\mathrm{w}$ poprzednich rundach badania nie sa możliwe bezpośrednie porównania zmian dynamiki dochodu pomiędzy okresami 2005-2007 (zawartymi w poprzednich opracowaniach Diagnozy) a 2007-2009 i 2009-2011.

Dynamika zmian dochodów z obu wyróżnionych grup nieznacznie różni się wyraźnie na niekorzyść osób biernych edukacyjnie - średni dochód osobisty netto osób dokształcających się w ciągu ostatnich dwóch lat (20092011) wzrósł o 22 proc. w porównaniu z 7 proc. dla osób biernych edukacyjnie. Jest to zdecydowana zmiana w porównaniu do okresu poprzedniego (lata 2007-2009), kiedy dynamika wzrostu dochodów była większa, ale jednakowa dla obu porównywanych grup osób tzn. zarówno dochody podnoszących swe kwalifikacje w ciągu ostatnich 2 lat, jak i biernych edukacyjnie wzrosły o średnio 37 proc. Dla przypomnienia - w latach 2005 i 2007 dochody na osobę w gospodarstwach domowych dokształcających się rosły szybciej niż osób niedokształcających się. Ta korzystna zmiana dochodów dla obu grup z lat 2007-2009 związana była z ogólnym wzrostem płac obserwowanym w ciagu tych dwóch lat, a szczególnie w 2008 r. Obniżenie dynamiki wzrostu płac w ostatnim okresie, tj. w latach 2009-2011, szczególnie dla osób biernych edukacyjnie związane jest ze spowolnieniem gospodarczym ostatnich lat.

Kobiety, które w ciągu ostatnich 2 lat podnosiły swoje kwalifikacje, charakteryzują się niższym średnim dochodem w porównaniu z mężczyznami aktywnymi edukacyjnie. W latach 2007-2009 dynamika średniego dochodu kobiet i mężczyzn, którzy podejmowali dokształcanie, była taka sama (wzrost o 37 proc.), co oznacza utrzymanie się 16 procentowej luki dochodowej według płci. Natomiast w latach 2009-2011 dochody osobiste mężczyzn rosły szybciej niż kobiet (24 proc. wobec 21 proc.), a zatem luka dochodowa według płci zwiększyła się do 18 proc. Sytuacja wyglacda odmiennie w przypadku osób biernych edukacyjnie. W latach 2007-2009 średnie dochody osobiste kobiet nie podnoszących swoich kwalifikacji wzrosły silniej niż dochody mężczyzn biernych edukacyjnie (40 proc. wobec 34 proc. dla mężczyzn), co prowadzi do spadku luki dochodowej z około 24 proc. w 2007 r. do 21 proc. w 2009 r. W latach 2009-2011 dochody biernych edukacyjnie osób rosły znacznie wolniej niż podnoszących we kwalifikacje, silniej jednak dla kobiet niż mężczyzn (8 proc. wobec 5 proc.), co przełożyło się na dalszy spadek luki dochodowej do 19 proc.

\footnotetext{
${ }^{59}$ Do obliczeń zastosowano średni dochód netto respondenta z ostatnich trzech miesięcy.
} 
Tabela 4.9.33. Rozktad osobistych dochodów netto pracujących respondentów w wieku 25-39 lat w 2007 r., 2009 r. i 2011 r.

\begin{tabular}{|c|c|c|c|c|c|c|c|c|c|c|c|c|}
\hline \multirow{3}{*}{$\begin{array}{l}\text { Wyodrębnione zbiorowości } \\
\text { respondentów }\end{array}$} & \multirow{2}{*}{\multicolumn{3}{|c|}{$\begin{array}{l}\text { Średnia osobistych dochodów na } \\
\text { oraz ich zróżnicowanie (w PLN) }\end{array}$}} & \multicolumn{9}{|c|}{ Kwartyle rozkładu osobistych dochodów (w PLN) } \\
\hline & & & & & artyl pie & & & wartyl d & & & wartyl tr & \\
\hline & 2007 & 2009 & 2011 & 2007 & 2009 & 2011 & 2007 & 2009 & 2011 & 2007 & 2009 & 2011 \\
\hline Osoby, które podnosiły swe & $1893 *$ & $2593 *$ & $3178^{*}$ & 1000 & 1500 & 1700 & 1500 & 2000 & 2300 & 2000 & 3000 & 3500 \\
\hline kwalifikacje w ciągu ostatnich 2 lat & $1723^{* *}$ & 2219 ** & $2870^{* *}$ & 1000 & & & & & & & & \\
\hline Pozostali respondenci & $\begin{array}{l}1435 \\
1010\end{array}$ & $\begin{array}{l}1959 \\
1461\end{array}$ & $\begin{array}{l}2110 \\
1450\end{array}$ & 805 & 1131 & 1300 & 1200 & 1600 & 1800 & 1800 & 2200 & 2500 \\
\hline $\begin{array}{l}\text { Kobiety, które podnosiły swe } \\
\text { kwalifikacje w ciaggu ostatnich } 2 \text { lat }\end{array}$ & $\begin{array}{l}1723 \\
1629\end{array}$ & $\begin{array}{l}2361 \\
2280\end{array}$ & $\begin{array}{l}2859 \\
2700\end{array}$ & 1000 & 1400 & 1500 & 1300 & 2000 & 2000 & 2000 & 3000 & 3000 \\
\hline Pozostałe kobiety & $\begin{array}{c}1224 \\
749\end{array}$ & $\begin{array}{l}1717 \\
1277\end{array}$ & $\begin{array}{l}1856 \\
1248\end{array}$ & 800 & 1000 & 1200 & 1000 & 1400 & 1500 & 1500 & 2000 & 2100 \\
\hline $\begin{array}{l}\text { Mężczyźni, którzy podnosili swe } \\
\text { kwalifikacje w ciągu ostatnich } 2 \text { lat }\end{array}$ & $\begin{array}{l}2055 \\
1779\end{array}$ & $\begin{array}{l}2815 \\
2145\end{array}$ & $\begin{array}{l}3494 \\
3002\end{array}$ & 1200 & 1800 & 2000 & 1600 & 2000 & 2800 & 2300 & 3051 & 3972 \\
\hline Pozostali mężczyźni & $\begin{array}{l}1620 \\
1162\end{array}$ & $\begin{array}{l}2172 \\
1555\end{array}$ & $\begin{array}{l}2293 \\
1514\end{array}$ & 1000 & 1300 & 1411 & 1300 & 1900 & 2000 & 2000 & 2500 & 2500 \\
\hline
\end{tabular}

* srednia dochodów ha osobę z ostatniego roku

** odchylenie standardowe dochodów na osobę z ostatniego roku 
Porównując zmiany sytuacji dochodowej pomiędzy osobami aktywnymi i biernymi edukacyjnie, odrębnie dla kobiet i mężczyzn zaobserwować można interesujące zmiany. Luka dochodowa pomiędzy kobietami podnoszącymi swoje kwalifikacje, a biernymi edukacyjnie zmniejszyła się z 40 proc. w 2007 r. do 37 proc. w 2009 r., aby w 2011 r. ponownie wzrosnąć, aż do poziomu 54 proc., natomiast wśród mężczyzn wzrosła od 27 proc. w 2007 r., poprzez 30 proc. w 2009 r., aż do 52,4 proc. w 2011 r.

Dynamika kwartyli rozkładów dochodów w obu grupach respondentów wykazuje korzystny wpływ aktywności edukacyjnej na rozkłady dochodów dla mężczyzn, silniejszy niż w latach 2007-2009. Największą dynamikę zmian dochodów mężczyzn aktywnych edukacyjnie wykazuje mediana, a następnie trzeci kwartyl, w przeciwieństwie do okresu 2007-2009, kiedy najsilniej wzrósł pierwszy kwartyl (por. Tabela 4.9.34.). Prowadzi to do silniejszego rozwarstwienia dochodów aktywnych edukacyjnie mężczyzn w ostatnim okresie, odwrotnie niż wśród mężczyzn niedokształcających się, których dochody wykazywały mniejsze zróżnicowanie w porównaniu do lat 2007-2009.

Korzyści z poprawy kwalifikacji przez kobiety dotyczyły tylko najniższych grup dochodowych (nieznaczny wzrost pierwszego kwartyla). Wynikiem zasadniczo odmiennym od uzyskanego dla lat 2007-2009 jest silniejszy wzrost dochodów kobiet biernych edukacyjnie niż kobiet podejmujących wysiłek dokształcania, co zdaje się świadczyć o relatywnym spadku korzyści z poprawy kapitału ludzkiego przy pewnym poziomie jego nasycenia.

Tabela 4.9.34. Dynamika zmian parametrów rozkładu dochodów osobistych netto pracujących respondentów $w$ wieku 25-39 lat w latach 2007, 2009 i 2011 (okres poprzedni =100)

\begin{tabular}{|c|c|c|c|c|}
\hline $\begin{array}{l}\text { Respondenci według płci i } \\
\text { aktywności edukacyjnej }\end{array}$ & $\begin{array}{c}\text { Średni osobisty } \\
\text { dochód }\end{array}$ & $\begin{array}{l}\text { Kwartyl } \\
\text { pierwszy }\end{array}$ & Kwartyl drugi & Kwartyl trzeci \\
\hline \multicolumn{5}{|c|}{ Ogółem } \\
\hline \multirow{2}{*}{ Aktywni edukacyjnie } & $1,37^{*}$ & 1,50 & 1,33 & 1,50 \\
\hline & $1,22 * *$ & 1,13 & 1,15 & 1,16 \\
\hline \multirow{2}{*}{ Bierni edukacyjnie } & 1,37 & 1,40 & 1,33 & 1,22 \\
\hline & 1,07 & 1,15 & 1,12 & 1,14 \\
\hline \multicolumn{5}{|c|}{ Kobiety } \\
\hline \multirow{2}{*}{ Aktywne edukacyjnie } & 1,37 & 1,40 & 1,54 & 1,50 \\
\hline & 1,21 & 1,07 & 1,00 & 1,00 \\
\hline \multirow{2}{*}{ Bierne edukacyjnie } & 1,40 & 1,25 & 1,40 & 1,33 \\
\hline & 1,08 & 1,20 & 1,07 & 1,05 \\
\hline \multicolumn{5}{|c|}{ Meżczyźni } \\
\hline \multirow{2}{*}{ Aktywni edukacyjnie } & 1,37 & 1,50 & 1,25 & 1,33 \\
\hline & 1,24 & 1,11 & 1,40 & 1,30 \\
\hline \multirow{2}{*}{ Bierni edukacyjnie } & 1,34 & 1,30 & 1,46 & 1,25 \\
\hline & 1,05 & 1,08 & 1,05 & 1,00 \\
\hline
\end{tabular}

* dynamika zmian dochodów w latach 2007-2009

**dynamika zmian dochodów w latach 2009-2011

Podsumowując, w okresie 2009-2011 dochody osób z obu wyróżnionych grup respondentów różnią się wyraźnie z korzyścią dla osób podejmujących dokształcanie się, a luka między średnimi dochodami osób aktywnych i biernych edukacyjnie powiększa się w porównaniu z okresem 2007-2009. Istnieją różnice w rozkładzie dochodów i ich dynamice dla obu wyróżnionych grup wśród kobiet i mężczyzn. Wpływ dokształcania na poprawę dochodów jest mniejszy dla pracujących kobiet niż mężczyzn.

Należy jednak podkreślić, że pomimo mniejszego wpływu dokształcania się zarówno na sytuacje dochodową pracujących kobiet, jak i status kobiet na rynku pracy niż ma to miejsce dla mężczyzn, to wciąż kobiety częściej niż mężczyźni podejmują wysiłek dokształcania się.

\subsubsection{Indywidualne determinanty aktywności edukacyjnej dorostych}

Omawiane w poprzednich częściach zróżnicowanie aktywności edukacyjnej dorosłych związanej z kwalifikacjami zawodowymi według ich cech demograficzno-społecznych, statusu na rynku pracy respondenta można syntetycznie ująć za pomocą odpowiedniego modelu. Skorzystano w tym celu z modelu logistycznego w postaci (Gruszczyński, 2002):

gdzie:

$$
P\left(Y=y_{i}\right)=F^{-1}\left(x^{T} \beta\right)=\frac{e^{x^{T} \beta}}{1+e^{x^{T} \beta}}
$$

Y - binarna zmienna losowa przyjmująca wartości: 1 - w przypadku gdy respondent podnosił swoje kwalifikacje zawodowe w ciągu ostatnich 2 lata. 0 - w przypadku gdy respondent nie podnosił swoich kwalifikacji zawodowych w ciągu ostatnich 2 lat.

F - dystrybuanta rozkładu logistycznego;

$\mathrm{x}$ - kolumnowy wektor zmiennych objaśniających;

$\beta$ - kolumnowy wektor parametrów. 
W modelu obok standardowych cech społeczno-demograficznych, jak wiek, płeć, poziom wykształcenia, klasa miejscowości zamieszkania uwzględniono także sytuację respondenta na rynku pracy oraz stan zdrowia respondenta mierzony niepełnosprawnością prawną lub biologiczną. Modele oszacowano osobno dla kobiet i mężczyzn (tabela 4.9.36.).

Wyniki estymacji modeli potwierdzają ustalenia analizy opisowej. Zarówno dla kobiet, jak i mężczyzn wiek jest istotną determinantą podejmowania aktywności edukacyjnej w latach 2007-2009, jak i w okresie 2009-2011, choć wydaje się mieć większy wpływ w okresie 2007-2009 - im osoby młodsze, tym prawdopodobieństwo podjęcia dokształcania się większe. Należy jednak zwrócić uwagę, iż kobiety w wieku 30-34 lata relatywnie rzadziej niż kobiety w wieku 25-29 lat i 35-39 lat decydują się na aktywność edukacyjną, co może być związane z nasileniem obowiązków rodzinnych.60 Drugim czynnikiem, który silnie determinuje prawdopodobieństwo podjęcia aktywności edukacyjnej jest wykształcenie, którego wpływ jest zbliżony w obu analizowanych okresach - im niższe wykształcenie, tym mniejsze prawdopodobieństwo dokształcania się.

Tabela 4.9.36. Wyniki estymacji modeli regresji logistycznej opisujacych aktywność edukacyjnq osób w wieku powyżej 25 lat dla lat 2009 i 2011.

\begin{tabular}{|c|c|c|c|c|c|}
\hline \multirow[t]{2}{*}{$\begin{array}{c}\text { Rodzaj zmiennej } \\
\text { niezależnej }\end{array}$} & \multirow[t]{2}{*}{ Zmienna niezależna - kategorie } & \multicolumn{2}{|c|}{$\begin{array}{l}\text { Oszacowanie ilorazu } \\
\text { szans mężczyźni }\end{array}$} & \multicolumn{2}{|c|}{$\begin{array}{c}\text { Oszacowanie ilorazu } \\
\text { szans kobiety }\end{array}$} \\
\hline & & 2009 & 2011 & 2009 & 2011 \\
\hline \multirow[t]{7}{*}{ Wiek } & 25-29 lat & $7,077 * * *$ & $4,655 * * *$ & $8,810 * * *$ & $5,841 * * *$ \\
\hline & $30-34$ lata & $4,204 * * *$ & $3,145 * * *$ & $5,913 * * *$ & $4,764 * * *$ \\
\hline & 35-39 lat & $4,437 * * *$ & $3,562 * * *$ & $7,311 * * *$ & $5,174 * * *$ \\
\hline & 40-44 lata & $3,872 * * *$ & $3,453 * * *$ & $5,487 * * *$ & $4,929 * * *$ \\
\hline & 45-49 lat & $2,642 * * *$ & $2,315 * * *$ & $5,488 * * *$ & $3,962 * * *$ \\
\hline & 50-54 lata & $2,001 * * *$ & $1,523 * * *$ & $3,216^{* * *}$ & $2,370 * * *$ \\
\hline & $55+$ & ref. & ref. & ref. & ref. \\
\hline \multirow[t]{4}{*}{ Wykształcenie } & podstawowe i niższe & $0,106 * * *$ & $0,222 * * *$ & $0,070 * * *$ & $0,153 * * *$ \\
\hline & zasadnicze zawodowe/gimnazjum & $0,228 * * *$ & $0,246 * * *$ & $0,118 * * *$ & $0,188 * * *$ \\
\hline & średnie & $0,462 * * *$ & $0,449 * * *$ & $0,380 * * *$ & $0,368 * * *$ \\
\hline & wyższe i policealne & ref. & ref. & ref. & ref. \\
\hline \multirow{4}{*}{$\begin{array}{l}\text { Dochód na jednostkę } \\
\text { konsumpcyjną w } \\
\text { gospodarstwie } \\
\text { domowym }\end{array}$} & I kwartyl & $0,787^{*}$ & $0,458 * * *$ & 0,887 & $0,379 * * *$ \\
\hline & II kwartyl & 0,917 & $0,523 * * *$ & $0,840^{*}$ & $0,764 * * *$ \\
\hline & III kwartyl & 0,914 & $0,616^{* * *}$ & 0,901 & $0,629 * * *$ \\
\hline & IV kwartyl & ref. & ref. & ref. & ref. \\
\hline \multirow[t]{3}{*}{ Status na rynku pracy } & pracujący & $1,989 * * *$ & $2,627 * * *$ & $2,155 * * *$ & $2,542 * * *$ \\
\hline & bezrobotni & $1,939 * * *$ & $5,046 * * *$ & $2,799 * * *$ & $4,266^{* * *}$ \\
\hline & bierni & ref. & ref. & ref. & ref. \\
\hline \multirow[t]{2}{*}{ Zdrowie } & sprawni & $1,782 * * *$ & 0,976 & 1,197 & 1,057 \\
\hline & niepełnosprawni & ref. & ref. & ref. & ref. \\
\hline \multirow{6}{*}{$\begin{array}{l}\text { Klasa miejscowości } \\
\text { zamieszkania }\end{array}$} & miasta powyżej 500 tys. mieszkańców & $1,826 * * *$ & $1,880 * * *$ & $2,903 * * *$ & $2,803 * * *$ \\
\hline & miasta 200-500 tys. mieszkańców & $1,681 * * *$ & $2,034 * * *$ & $2,282 * * *$ & $2,885 * * *$ \\
\hline & miasta 100-200 tys. mieszkańców & $1,449 * * *$ & $1,529 * * *$ & $1,438 * * *$ & $1,586 * * *$ \\
\hline & miasta 20-100 tys. mieszkańców & $1,319 * * *$ & $1,349 * * *$ & $1,565 * * *$ & $1,857 * * *$ \\
\hline & miasta poniżej 20 tys. mieszkańców & 1,043 & $1,331 * *$ & 1,190 & $1,552 * * *$ \\
\hline & wieś & ref. & ref. & ref. & ref. \\
\hline \multirow{2}{*}{\multicolumn{2}{|c|}{$\begin{array}{l}\mathrm{N} \\
\text { pseudo } \mathrm{R}^{2} \text { (Nagelkerke) }\end{array}$}} & 10776 & 11049 & 12532 & 12732 \\
\hline & & 0,206 & 0,252 & 0,356 & 0,323 \\
\hline
\end{tabular}

Zmienne istotne statystycznie przy poziomie istotności: ***-0,01, **-0,05,*-0,1

Dochody na jednostkę konsumpcyjną w gospodarstwie domowym nie były zmienną silnie determinująca aktywność edukacyjną w latach 2007-2009, w przeciwieństwie do lat 2009-2011, kiedy wyższe dochodu zwiększały prawdopodobieństwo podejmowania dokształcania się. W pierwszym okresie może być to związane z dużą dostępnością dofinansowanych w znacznym stopniu działań edukacyjnych z Europejskiego Funduszu Społecznego czy ze środków pracodawcy, w okresie 2009-2011 w związku z pogłębiającym się kryzysem wielu pracodawców mogło zrezygnować z dofinansowania dokształcania się własnych pracowników, co spowodowało przeniesienie ciężaru finansowania działań edukacyjnych na gospodarstwa domowe.

Status na rynku pracy jest zmienną istotnie wpływającą na prawdopodobieństwo podjęcia dokształcania się. Osoby obecne na rynku pracy (pracujący i bezrobotni) podejmują aktywność edukacyjną częściej niż bierni zawodowo. W $2011 \mathrm{r}$. w porównaniu do biernych zawodowo osoby bezrobotne obojga płci miały znacząco wyższe prawdopodobieństwo dokształcania się niż pracujących, w 2009 r. dotyczyło to jedynie kobiet, ale różnica szans była niewielka.

Stan zdrowia jest istotną determinantą podjęcia aktywności edukacyjnej przez mężczyzn, ale tylko w 2009 r. mężczyźni bez niepełnosprawności mają o około 78 proc. większe prawdopodobieństwo podjęcia dokształcania się

\footnotetext{
${ }^{60}$ W 2008 r. średni wiek urodzenia dziecka wynosił 28,46 lat, w 2009 r. 28,61 lata (Eurostat, 2011)
} 
w ciągu ostatnich dwóch lat w porównaniu z mężczyznami niepełnosprawnymi. W $2011 \mathrm{r}$. wpływu zdrowia na podejmowanie inicjatyw edukacyjnych nie zaobserwowano.

Klasa miejscowości zamieszkania istotnie różnicuje prawdopodobieństwo podjęcia dokształcania, silniej u kobiet niż u mężczyzn w obu analizowanych okresach. Wraz ze wzrostem wielkości miejscowości zamieszkania rośnie prawdopodobieństwo podjęcia aktywności edukacyjnej, szczególnie w odniesieniu do miast średnich i dużych w porównaniu $\mathrm{z}$ terenami wiejskimi.

Podsumowując, wyniki analiz modelowych potwierdzają wysoką selektywność procesu dokształcania się osób w wieku powyżej 25 lat. Aktywność edukacyjną podejmują osoby młode, dobrze wykształcone, o wyższych dochodach, aktywne zawodowo, zamieszkujące duże aglomeracje miejskie. 